\author{
UNIVERSIDADE DE SÃO PAULO \\ MUSEU DE ARQUEOLOGIA E ETNOLOGIA \\ PROGRAMA DE PÓS-GRADUAÇÃO EM ARQUEOLOGIA
}

SILVIA KAMEYAMA DOMINGOS LEAL

Uso da cartografia e da geomorfologia na construção de mapas de potencial arqueológico para sítios pré-coloniais: um estudo de caso em Pindamonhangaba, estado de São Paulo

São Paulo 


\title{
Uso da cartografia e da geomorfologia na construção de mapas de potencial arqueológico para sítios pré-coloniais: um estudo de caso em Pindamonhangaba, estado de São Paulo
}

\author{
Versão Corrigida \\ (A versão original encontra-se na unidade que aloja \\ o Programa de Pós-graduação)
}

Dissertação apresentada ao Programa de Pósgraduação em Arqueologia do Museu de Arqueologia e Etnologia da Universidade de São Paulo para obtenção do título de Mestre em Arqueologia.

Área de Concentração: Arqueologia

Orientador: Prof. Dr. Astolfo Gomes de Mello Araujo

Linha de Pesquisa: Arqueologia e Meio ambiente

São Paulo 
Autorizo a reprodução e divulgação integral deste trabalho, por qualquer meio convencional ou eletrônico, para fins de estudo e pesquisa, desde que citada a fonte.

CATALOGAÇÃO NA PUBLICAÇÃO (CIP)

Serviço de Biblioteca e Documentação do

Museu de Arqueologia e Etnologia da Universidade de São Paulo

L435 Leal, Silvia Kameyama Domingos

Uso da cartografia e da geomorfologia na construção de mapas de potencial arqueológico para sítios pré-coloniais: um estudo de caso em Pindamonhangaba, estado de São Paulo / Silvia Kameyama Domingos Leal; orientador Astolfo Gomes de Mello Araujo -- São Paulo, 2017.

Dissertação (Mestrado) - Universidade de São Paulo, Museu de Arqueologia e Etnologia, Programa de Pós-graduação em Arqueologia, 2017.

1. Sítios pré-coloniais. 2. Vale do Paraíba. 3. Geoarqueologia. 4. Pindamonhangaba. 5. Modelos Preditivos. I. Araujo, Astolfo Gomes de Mello. II. Universidade de São Paulo. Museu de Arqueologia e Etnologia. Programa de Pós-Graduação em Arqueologia. III. Título. 
LEAL, S. K. D. Uso da cartografia e da geomorfologia na construção de mapas de potencial arqueológico para sítios pré-coloniais: um estudo de caso em Pindamonhangaba, estado de São Paulo. 2017. 134 f. Dissertação (Mestrado em Arqueologia) - Museu de Arqueologia e Etnologia, Universidade de São Paulo, São Paulo, 2017.

Aprovada em:

\section{Banca Examinadora}

Prof. Dr.

Instituição:

Julgamento:

Prof. Dr.

Instituição:

Julgamento:

Prof. Dr.

Instituição:

Julgamento 


\section{DEDICATÓRIA}

À minha família e a todos os amigos que me ajudaram a realizá-lo, dedico este trabalho. 


\section{AGRADECIMENTOS}

Neste trabalho caberia um capítulo somente de agradecimentos, pois o mesmo foi construído com a ajuda de muitas mãos. Ao chegar ao final dessa trajetória, posso dizer que sou uma pessoa mais feliz, o que faz todo o sentido se considerarmos as palavras do monge beneditino David Steindl-Rast ao afirmar que é o sentimento de gratidão que traz a felicidade. Não se congela o tempo para fazer mestrado ou doutorado, além da pesquisa, é preciso continuar tocando a vida. Por demandar momentos de maior "imersão", essa "fase" nos priva do convívio mais intenso com as pessoas que amamos, e, normalmente, são elas que mais nos ajudam. Aproveito, então, esse espaço para expressar a minha gratidão a todos os que, de alguma forma, me ajudaram a desenvolver e a concluir esse trabalho.

Obrigada:

Ao CNPq, pela concessão da bolsa de mestrado, processo número 130.117/2015-3.

Ao professor Astolfo Araujo, pelo tempo que dispensou para as reuniões de orientação, pelo seu apoio quando participei do curso de verão na Universidade de Exeter, no Reino Unido e da escavação arqueológica na Gruta Calla di Santi, na Itália. Sou grata também pela oportunidade de participar de alguns campos acadêmicos, os quais foram bastante importantes para a minha formação.

Aos professores do MAE, principalmente aos que deram suas contribuições durante ou após o exame de qualificação: José Luiz de Morais, Marisa Afonso e Eduardo Neves. Aos funcionários, especialmente, aos da secretaria acadêmica e da biblioteca, sempre tão atenciosos. Sou grata, em particular, por toda a atenção, conselhos e sugestões de leitura dados pelo senhor Hélio Rosa.

Aos institutos de pesquisa e empresas que enviaram bibliografias ou que me receberam durante o desenvolvimento da pesquisa: IPHAN de São Paulo, bibliotecas municipais de Pindamonhangaba e de Roseira, Instituto de Estudos Vale paraibanos, Instituto Geológico e Zanettini Arqueologia.

A todos os órgãos e seus responsáveis que permitiram que eu fizesse as etapas de controle de campo em Pindamonhangaba: sr. Hélio Takada, diretor técnico da APTA Regional Vale do Paraíba; senhoras Sueli Salomão e Maria Áurea, responsáveis pela administração dos Parques da Juventude e da Cidade; sr. Osmar Pacca, presidente do Aeroclube; sr. Jânio Lerário, proprietário do terreno onde se 
localiza a Lagoa do Paturi, prof. Inácio Bianchi, da UNESP de Guaratinguetá, que foi nosso guia pela Falésia Paraíso; sr. José Aparecido Correia e Wallace Pereira, nossos "tradadores", e família Almeida, proprietária do sítio São José, no bairro Pinga. Diferentemente das demais áreas, o sítio São José é o local de moradia de algumas pessoas, e abrir o seu "quintal" para um grupo de "universitários" foi um gesto de grande boa vontade, por isso, sou muito grata à Paula, dona Joana, Felipe e demais familiares.

Aos discentes: Rodrigo de Angeles, Fábio Grossi, Thiago Kater, Marcel Lopes, Tatiane Souza, Guilherme Alarsa, Paulo Spengler, Alexandre Recoaro, Alexandre Felizardo, Rafael Almeida e ainda Glauco Constantino, que lá em 2013 me ajudou a começar a pensar em um projeto. Por se tratar de um curso de pósgraduação, o convívio com a maioria dos colegas da Arqueologia acaba não sendo frequente, mas a ajuda deles veio sempre quando precisei.

Ao grupo Nostradamos por me incluir na rotina e dar espaço para discutir as problemáticas da minha pesquisa, bem como aos colegas e professores de todas as disciplinas que cursei, tanto na Geografia como na Geociências. E também ao prof. Júlio Paisani, da UNIOESTE, campus de Francisco Beltrão - PR, pela indicação de bibliografias.

Aos laboratórios da FFLCH, pelas contribuições recebidas por meio de material emprestado e de bate-papos profícuos sobre temas relacionados a pesquisa, trocados com o Pablo Nepomuceno, do LASERE, e, principalmente, com o pessoal do LABOPED. Serei eternamente grata ao Marcos Pinheiro pelo suporte em campo e por me ensinar os primeiros passos no Arcgis. Muitas vezes, uma simples pausa para pedir uma informação nos corredores desse departamento, acabou resultando em insights e, posteriormente, auxílio com bibliografias e técnicas de pesquisa. Nesse sentido, sou grata aos geógrafos Viviane Portela, Walkiria Melo, Aberto Barioni e Rodrigo dos Santos.

A AmbGis, por oferecer uma oportunidade de inserção no mercado de trabalho na área de Arqueologia Preventiva quando a bolsa chegou ao fim. Ao Marcelo Costa, gradeço a confiança depositada e o suporte técnico recebido para a execução de algumas fases deste trabalho.

As amigas "das antigas": Márcia Cabral, Paula Almeida, Melissa Vieira, Lilian Souza e Karen Ciuffo, que me ajudaram a manter a lucidez em momentos de maior dificuldade no mundo acadêmico; ao apoio dado, à distância, pelos amigos que 
fiz na terra do pé-vermelho, especialmente ao Jônatas Cândido e ao Leonardo Mamede, que se inteiraram mais sobre a pesquisa; às amigas de Campinas: Mara Ramos, Maria Silvia Carvalho e Sandra Fonseca, pela amizade, incentivo e apoio financeiro nos momentos críticos; aos amigos Amanda Melo e Walter Cancelieri, pelas aventuras em Exeter, conversas profundas e "presença", e, ao apoio de Silvana Vieira e Ivone Murakami, pela estadia na Itália e no Reino Unido, respectivamente, pois a experiência no âmbito internacional, mesmo curta, sem dúvida ajudou a ampliar meus horizontes e refletiu no desenvolvimento do trabalho.

Aos amigos Rafael Guimarães e Bruno Kawano, pela amizade, por me receberem no CRUSP todas as vezes que precisei, pela companhia no restaurante universitário e por todas as conversas sobre o desenvolvimento dos nossos projetos.

Aos amigos que foram fundamentais para a realização da pesquisa: Suelen Bueno, Olívia Ricci e Thomas Schrage. Embora cada um resida em um município diferente, estiveram presentes em todas as fases do trabalho e se dispuseram a colocar a mão na massa, seja nos trabalhos de gabinete, de campo ou de laboratório.

A toda a minha família, cujo apoio foi essencial e incondicional, principalmente para a realização das etapas de campo. Pelo apoio logístico e financeiro, muitas estadias, refeições e conversas, expresso minha gratidão aos meus tios Íris, Lina e Chico, que tornaram viável eu fazer mestrado em São Paulo, viajando constantemente. Muito obrigada aos meus pais Irene e Sebastião, aos meus irmãos: Davi, Samuel, Denise, Marco e Paulo e às minhas cunhadas e sobrinhos, Nélif e Michelle, Matheus e Nícolas. Abdicar da estabilidade proporcionada por um cargo público para "viver" de bolsa e poder se dedicar, integralmente aos estudos, por dois anos, foi uma loucura só cometida porque tive a certeza de que eles me apoiariam. Ao Ní, sou grata pela alegria que me proporcionou nos momentos "de folga" que passamos juntos, afinal, nada como brincar de escavar ou de procurar um tesouro para relaxar e, ao mesmo tempo, pensar nos "problemas de pesquisa".

Ao amigo "X", que poderia ser chamado de $Y, W$ ou Z, mas que vou chamar de " $A$ ", devido à importância que teve na minha vida pessoal, em determinados momentos, no período da construção da dissertação. Agradeço-lhe por ter deixado alguns dias realmente difíceis muito mais leves e alegres, e por me trazer a paz necessária para seguir em frente, dentro do seu abraço. 


\section{EPÍGRAFE}

"[..] - Tu não és ainda para mim senão um garoto inteiramente igual a cem mil outros garotos. [...] Mas, se tu me cativas, nós teremos necessidade um do outro. Serás para mim único no mundo. E eu serei para ti única no mundo..."

(SAINT-EXUPÉRY, 2009, p.66). 


\section{RESUMO}

\section{LEAL, S. K. D. Uso da cartografia e da geomorfologia na construção de mapas}

de potencial arqueológico para sítios pré-coloniais: um estudo de caso em Pindamonhangaba, estado de São Paulo. 2017. 134 f. Dissertação (Mestrado em Arqueologia) - Museu de Arqueologia e Etnologia, Universidade de São Paulo, São Paulo, 2017.

Nesta dissertação, apresentamos os procedimentos adotados para a elaboração de um modelo geoarqueológico de localização de material arqueológico relacionado aos sítios pré-coloniais. A área de estudo abrangeu os limites da carta topográfica do município de Pindamonhangaba, situado na região do Vale do Paraíba no estado de São Paulo. Para a construção desse modelo, realizamos o mapeamento morfológico de feições que julgamos ser propícias ao assentamento humano, por meio da estereoscopia de fotos aéreas e uso de técnicas de geoprocessamento. Com base na carta topográfica, também se produziu uma carta hipsométrica e perfis topográficos. Após a confecção de um mapa prévio de potencial arqueológico, com destaque para as áreas das grandes depressões, colinas e do terraço fluvial do rio Paraíba do Sul, foram elencados 3 setores para a realização de prospecção arqueológica. A execução das etapas de controle de campo resultou na coleta de um fragmento de cerâmica, encontrado a 3 metros de profundidade, próximo a uma depressão, bem como de alguns fragmentos de quartzo, em relevo escarpado que, após análise em laboratório, foram classificados como duvidosos quanto ao potencial arqueológico. Conclui-se que o emprego da Geoarqueologia no estudo de grupos pré-coloniais do Vale do Paraíba Paulista constituiu-se de uma abordagem eficiente para o entendimento do padrão de assentamento em função da distribuição dos recursos naturais.

Palavras-chave: Sítios pré-coloniais. Vale do Paraíba. Geoarqueologia. Pindamonhangaba. Modelos preditivos. 


\begin{abstract}
LEAL, S. K. D. The use of cartography and geomorphology at creation of archaelogical potential maps for pre-colonial sites: a case of study in Pindamonhangaba, São Paulo State. 2017. 134 f. Dissertação (Mestrado) - Museu de Arqueologia e Etnologia, Universidade de São Paulo, São Paulo, 2017.

In this dissertation, we present the procedures used for the creation of an archaeogeological model employed for the localization of archeological material related to precolonial sites. This study encompassed the city limits of Pindamonhangaba, in the Vale do Paraiba region, located in the state of Sao Paulo. For the purposes of this project, we used morphological mapping we deemed suitable for human settlement, through stereocopy of aerial photographs and geoprocessing techniques. Based on the topographic map, we also produced a hypsometric map and topographic profiles. After the compilation of a previous map with archeological potential, highlighting areas of great depressions, hills and the fluvial terrain of the Paraiba do Sul River, three sectors were selected for the archeological prospection. The field work yielded the discovery of a ceramic fragment, found in a excavation of 3 meters deep into the ground, close to a depression, as well as some quartz fragment. After laboratorial testing, these were found to have no archeological value. It is concluded that employing techniques from Geoarcheology to study precolonial groups in Paraíba Paulista Valley emerges as an efficient approach to the knowledgle of natural resources-oriented settlement patterns.
\end{abstract}

Keywords: Precolonial sites. Paraíba Valley. Geoarchaeology. Pindamonhangaba. Modelos preditivos. Predictive Modeling. 


\section{LISTA DE TABELAS}

Tabela 1 - Ranqueamento dos Sítios Arqueológicos com base na Geomorfologia local 36

Tabela 2 - Ocorrências arqueológicas no Vale do Paraíba Paulista ------------------- 62

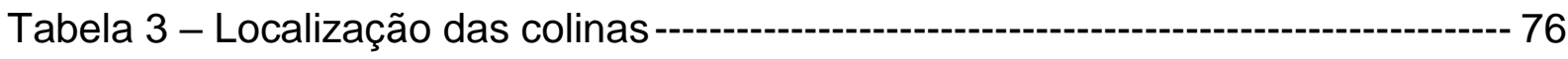

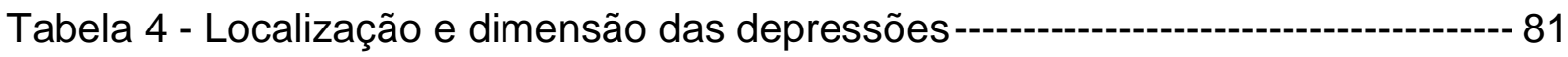

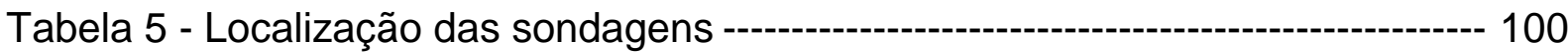




\section{LISTA DE FOTOS}

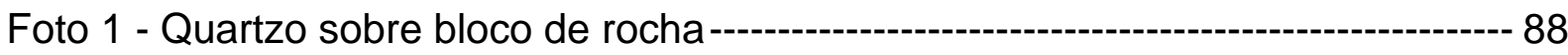

Foto 2 - Abrigo rochoso --- 88

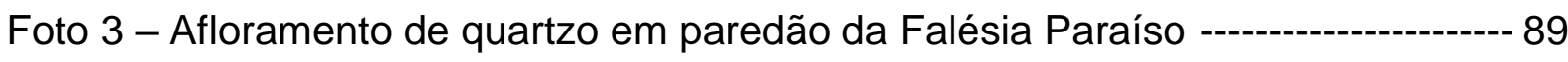

Foto 4 - Depressão D1 ---------------

Foto 5 - Peneiramento do sedimento escavado ---

Foto 6 - Depressão D129 - 92

Foto 7 - Análise da cor do solo por meio do Munsell ---

Foto 8 - Área de prospecção em morro---

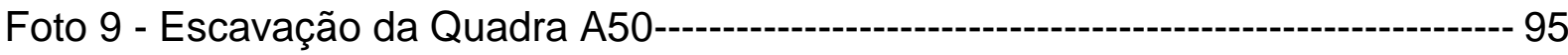

Foto 10 - Cúpules em abrigo próximo a unidade escavação---------------------------- 96

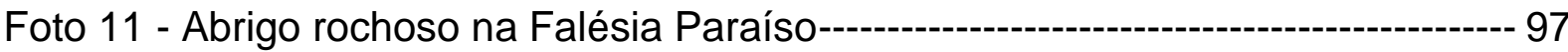

Foto 12 - Linhas na Falésia Paraíso ---

Foto 13 - Linhas na Falésia Paraíso ----o- 97

Foto 14 - Fragmento de cerâmica - face interna --- 114

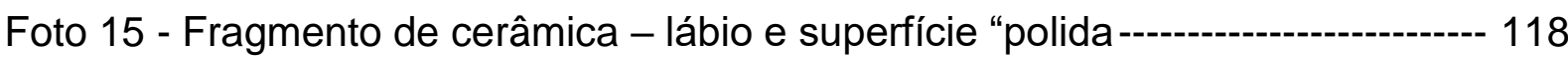

Foto 16 - Indício de "banho e de queima" --

Foto 17 - Quartzo sacaroide ---------- 119

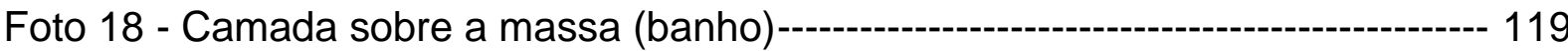

Foto 19 - Fraturas sobre a superfície da cerâmica ------------------------------- 120 


\section{LISTA DE FIGURAS}

Figura 1 - Mapa de potencial arqueológico 36

Figura 2 - Mapa de classes de probabilidade de ocorrências arqueológicas $-37$

Figura 3 - Localização do município de Pindamonhangaba, estado de São Paulo. - 40 Figura 4 - Localização da Bacia de Taubaté na Região do Vale do Paraíba$-44$ Figura 5 - Mapa Geológico da Bacia de Taubaté. Cor amarela: aluviões recentes; Cor vermelha: embasamento cristalino; Cor verde: sedimentos antigos. Hachurado: cidades-

Figura 6 - Solos do estado de São Paulo 48

Figura 7 - Unidade de Gerenciamento de Recursos Hídricos do Estado de São Paulo

Figura 8 - Recorte da Carta Topográfica de Pindamonhangaba destacando uma área de interesse54

Figura 9 - Imagem da Lagoa do Paturi em Pindamonhangaba 55

Figura 10 - Identificação preliminar das depressões $-73$

Figura 11 - Conjunto de lagoas no município de Pindamonhangaba, cuja aparência assemelha-se a de meandros abandonados $-11$

Figura 12 - Foto aérea digitalizada com o layer $-80$

Figura 13 - Depressão 129 na área 3 99

Figura 14 - Localização das sondagens na Área 1 102

Figura 15 - Distribuição das sondagens na vertente 103

Figura 16 - Perfis das unidades estratigráficas no morro 104

Figura 17 - Prospecção em área de depressão 107

Figura 18 - Perfil das unidades estratigráficas na área de depressão 109 
1 INTRODUÇÃO -- 15

2 PRESSUPOSTOS TEÓRICOS E REVISÃO DA LITERATURA --

2.1 A CIÊNCIA GEOMORFOLÓGICA E SEU OBJETO DE ESTUDO -- 21

2.2 MÉTODOS EMPREGADOS EM GEOMORFOLOGIA-- 24

2.3 CARACTERÍSTICAS DO MAPEAMENTO GEOMORFOLÓGICO -------------- 26

2.4 A GEOARQUEOLOGIA COMO ABORDAGEM TEÓRICA

2.5 O "FATOR GEO" NA INVESTIGAÇÃO DE SÍTIOS ARQUEOLÓGICOS--------- 30

2.6 A ABORDAGEM MATERIALISTA EM ARQUEOLOGIA --- 31

2.7 O SURVEY ARQUEOLÓGICO- 33

2.8 O USO DE MODELOS PREDITIVOS NA PESQUISA ARQUEOLÓGICA ------- 33

3 CARACTERIZAÇÃO DA ÁREA DE ESTUDO- 39

3.1 LOCALIZAÇÃO-- 39

3.2 A COBERTURA VEGETAL ---

3.3 ASPECTOS CLIMÁTICOS --- 41

3.4 ASPECTOS GEOLÓGICOS E GEOMORFOLÓGICOS--- 41

3.4.1 Como se forma uma Bacia Sedimentar -a- 42

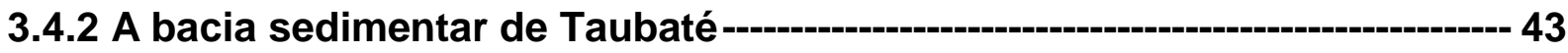

3.4 A COBERTURA PEDOLÓGICA --- 47

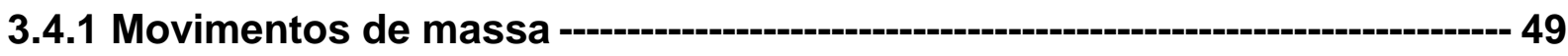

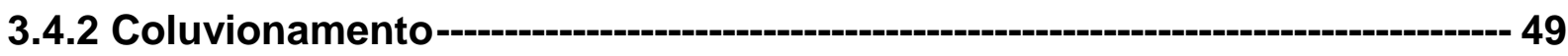

3.5 A REDE DE DRENAGEM -- 50

3.5.1 As depressões circulares----o--- 51

3.5.2 Os terraços fluviais - 55

4 A DISTRIBUIÇÃO DO REGISTRO ARQUEOLÓGICO NA ÁREA DE ESTUDO - 57

4.1 SÍTIOS PALEOÍNDIOS E A OCUPAÇÃO DO CONTINENTE AMERICANO---- 57

4.2 O POVOAMENTO DO VALE DO PARAÍBA PAULISTA -- 60

4.2.1 Ocorrência de sítios arqueológicos do Vale do Paraíba Paulista ------- 61

4.2.2 Pesquisas arqueológicas em andamento na área de estudos------------- 66

4.2.3 Tradições arqueológicas do Vale do Paraíba-- 66

4.2.4 Locais preferenciais de ocupação no Vale do Paraíba-----:---:-a----- 69 
5.1 USO DE IMAGENS DE SATÉLITES EM MAPEAMENTO--

5.2 A FOTOINTERPRETAÇÃO AÉREA-- 73

5.3 TÉCNICAS DE AFERIÇÃO DO TAMANHO DAS DEPRESSÕES -------------- 76

5.4 O USO DE GIS NA PESQUISA ARQUEOLÓGICA -

5.5 TESTANDO UMA HIPÓTESE---- 85

5.5.1 Atividades da primeira etapa de campo --- 87

5.5.2 Atividades da segunda etapa de campo---o--.-- 91

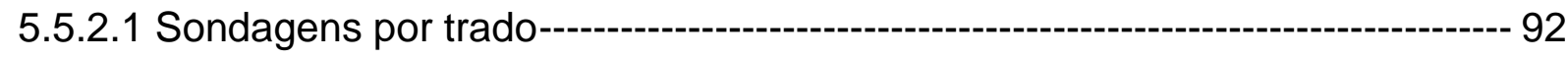

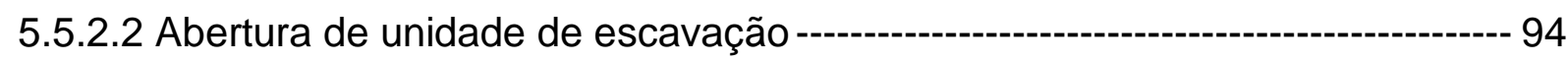

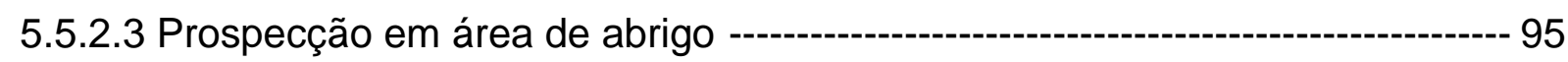

6 RESULTADOS--.-- 99

6.1 DADOS DAS SONDAGENS - 99

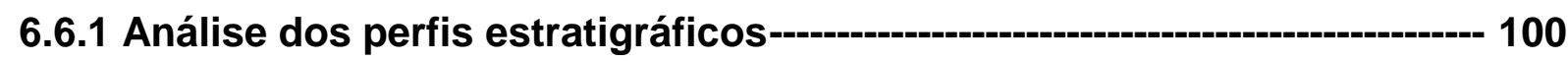

6.2 DESCRIÇÃO DO MATERIAL ESCAVADO---- 110

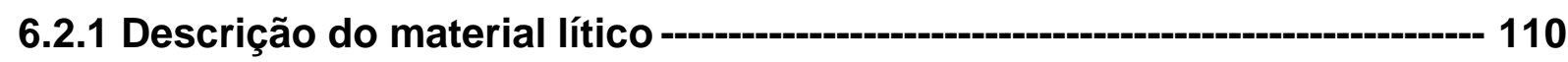

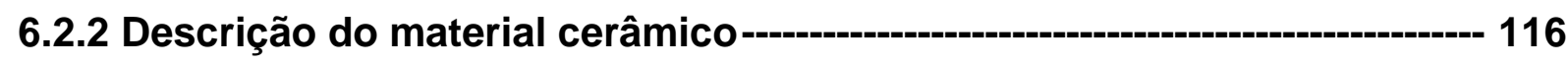

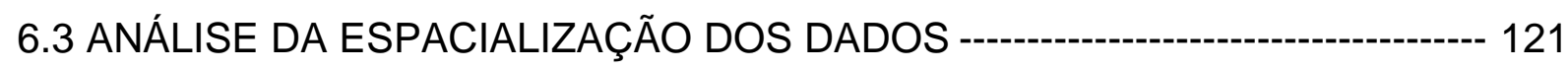

7 CONSIDERAÇÕES FINAIS - 122

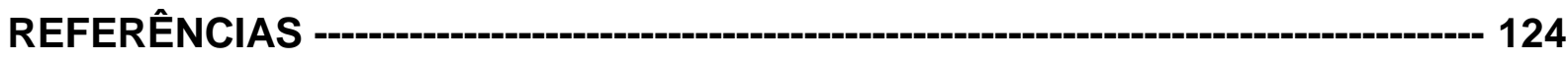

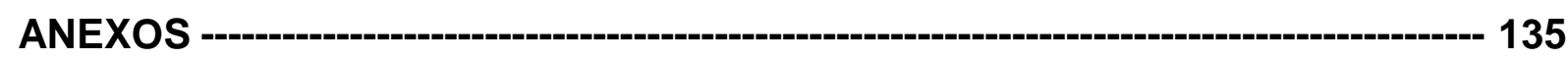




\section{INTRODUÇÃO}

O Vale do Paraíba é, atualmente, importante eixo industrial e tecnológico do estado de São Paulo e, também por isso, intensamente povoado. A julgar pela densidade de material arqueológico conhecido em seu território, evidenciado nos estudos de Cali (1999), Robrahn-González e Zanettini (1999), Caldarelli (2003), Gaspar, Barbosa e Cordeiro (2007), Assunção, Belém, Juliani (2011), Lopes (2014), entre outros, seu povoamento já era expressivo na ocasião do início da colonização europeia. Tais pesquisas revelaram a ocorrência de sítios arqueológicos e achados fortuitos relacionados a grupos indígenas (principalmente Tupiguarani e Aratu) e também a grupos caçadores-coletores na região.

Em seu primeiro ano de funcionamento, o PRONAPA - PROGRAMA NACIONAL DE PESQUISA ARQUEOLÓGICA, pretendeu abranger a região do Vale do Paraíba, porém, o foco dos trabalhos teve que ser redirecionado para a região de Itararé e Itapeva, devido à densa ocorrência de sítios arqueológicos naquela área e a necessidade de resgatá-los. (MARANCA, 1969). Após, a maior parte dos estudos de arqueologia no Vale, foi realizada em decorrência da execução de pesquisas arqueológicas exigidas para fins de liberação de licença ambiental.

Ao se pensar em um cenário no qual os vestígios arqueológicos relacionados a sítios pré-coloniais e também a grupos Paleoíndios pudessem ser identificados de forma menos fortuita, optou-se pelo emprego de métodos das geociências, e consequentemente, por um viés geoarqueológico para direcionar a pesquisa. As vantagens do emprego de uma abordagem geoarqueológica para a detecção de sítios Paleoíndios, de forma mais sistemática, também são apontadas em Araujo (2013).

Outros temas que se relacionam ao estudo de sítios pré-coloniais e que foram desenvolvidos ao longo desta pesquisa são: geologia e geomorfologia do Vale do Paraíba, paleoambientes (paleoturfa), depressões circulares interfluviais (lagoas pseudo-cárticas), colinas terciárias, sítios arqueológicos do final do Pleistoceno e início do Holoceno e mapeamento morfológico.

Como recorte espacial da pesquisa, foi utilizada a carta topográfica do município de Pindamonhangaba, que também abrange porções dos municípios de Roseira, Aparecida, Potim e Guaratinguetá, todos inseridos no centro geográfico do 
Vale do Paraíba, região que além de ocupada por grupos ceramistas, supõe-se ser também um provável corredor de passagem de povos mais antigos, vindos do litoral em direção ao Planalto do Sudeste e do interior para o litoral.

O objetivo geral deste estudo foi o de fornecer subsídios para a detecção de sítios pré-coloniais. O produto final consistiu na apresentação de um modelo geoarqueológico de localização de material arqueológico relacionado à sítios précoloniais. Como objetivos específicos, foram elaborados: 1 - um banco de dados da área estudada que ajudou na identificação de pontos com potencial arqueológico; 2 mapas temáticos auxiliares para análise desses dados e 3 - uma pesquisa arqueológica a partir de uma perspectiva regional e do emprego de uma abordagem geoarqueológica, com ênfase em Geoarqueologia Tropical. 


\section{PRESSUPOSTOS TEÓRICOS E REVISÃO DA LITERATURA}

Este projeto de pesquisa nasceu a partir de algumas perguntas iniciais, que foram elaboradas em decorrência de algum conhecimento prévio do assunto e de observações da paisagem vale paraibana. Ainda durante o período de levantamento da bibliografia fundamental para a sua estruturação, houve uma preocupação em se reconhecer alguns dos elementos principais que norteiam as pesquisas científicas teoria, hipótese, método, técnica - bem como definir, para este estudo, alguns conceitos específicos pertinentes à temática: arqueologia, artefato, cultura, geoarqueologia, geomorfologia e paleoambiente.

Para Matallo Jr. (2011), o conhecimento científico se diferencia de outras formas de discurso, como a religiosa, a poética e a mítica, porque suas afirmações podem ser testadas. E ciência também se diferencia do senso comum, embora este seja a base de construção das teorias científicas. "O senso comum é um conjunto de informações não sistematizadas que aprendemos por processos formais, informais e, às vezes, inconscientes, e que inclui um conjunto de valorações. [...]" (MATALLO JUNIOR, 2011, p.19).

Ao pensar sobre o que é considerado ciência, há consenso sobre ideias relacionadas à: sua expressão em teorias, capacidade de sistematização e poder explanatório, bem como à coerência de proposições (LACEY, 2000; MATALLO JUNIOR, 2011; DUNNELL, 2007). Por considera-las mais abrangentes, optou-se pela adoção das seguintes definições de ciência e de teoria:

[...] ciência é um estudo sistemático derivado de um sistema lógico que resulta na ordenação dos fenômenos aos quais ela se aplica de maneira a tornar os fenômenos não-históricos e suscetíveis de explanação. (DUNNELL, 2007, p.39).

A teoria, portanto, consiste em ideias sobre classes gerais de fenômenos. [...] é a teoria que separa as várias disciplinas entre si, e não o seu objeto de estudo. [...] As classes, as categorias pelas quais o mundo real é conceituado, são os elementos primordiais e cruciais da teoria. (DUNNELL, 2007, p.54.).

Ressalta-se neste estudo a identificação de pelo menos duas abordagens teóricas, uma materialista, relacionada a "fase" processualista da Arqueologia e outra geoarqueológica, com ênfase em Geoarqueologia Tropical. 
Visto que a formulação de possíveis respostas às perguntas da pesquisa, ou seja, as explicações ou afirmações, amparadas por uma teoria, a respeito de determinados fenômenos, em pesquisa científica, são denominadas hipóteses, a formulação delas foi o nosso ponto de partida.

\begin{abstract}
Uma hipótese é um conjunto de afirmações - apoiadas por teorias - a respeito de um fenômeno ou situação que se deseja estudar, obtidas através de observações preliminares, isto é, excursão prévia ao local, anotação de condições e problemas significativos, leitura da bibliografia existente, coleta de dados estatísticos, gráficos, e da cartografia relacionada com a pesquisa a ser realizada etc. (SILVA, 1978, p.78).
\end{abstract}

Outra característica muito importante da hipótese é que ela deve poder ser testada, verificada em outros estudos, em condições iguais. Do contrário, não será considerada uma hipótese científica válida e não será incluída no rol da ciência. (MATALLO JUNIOR, 2011; SILVA, 1978).

Logo, a principal hipótese desta pesquisa se refere a preferência pelo assentamento de povos pretéritos em áreas de colina, nos terraços fluviais e próximos a grandes depressões na região do Vale do Paraíba, estado de São Paulo. A escolha de tais lugares se daria pelas condições ambientais tais como a proximidade de recursos (água, alimentos) e de matérias-primas (minerais e rochas para lascar e barro para produzir cerâmica), além de uma visão estratégica do vale, no caso de sítios nos topos das colinas. Supondo-se que esses locais foram ocupados para a realização de diferentes tipos de atividades, espera-se encontrar vestígios dessas ocupações na forma de ocorrências arqueológicas ou se em maior densidade, como sítios arqueológicos pré-coloniais.

O fato de o Vale do Paraíba Paulista não apresentar material arqueológico pré-colonial abundante em superfície, seja ele de natureza lítica ou cerâmica, nos leva a formulação de uma segunda hipótese. Esta diz respeito a influência de um ambiente tropical no modelado do relevo e consequente soterramento do material arqueológico. A identificação, em 2008, dos sítios líticos Paleoíndios Pica-pau Amarelo e Carcará, no município de São José dos Campos, no topo de uma colina, em profundidades que variaram de 30 a 130 centímetros no primeiro (A LASCA, 2011), e de 10 a 260 centímetros no segundo (A LASCA, 2011; A LASCA, 2012), corroboram com esta suposição. Ambos os sítios estão distantes cerca de quarenta quilômetros da nossa 
área de estudos, onde as condições geomorfológicas de relevo colinar são as mesmas.

De acordo com Castro (1978) e Dunnell (2007), conceitos são construídos, são palavras e quando usados em pesquisa científica devem ser apresentados de forma precisa, no sentido de identificar as unidades discutidas. Assim, cada disciplina utiliza conceitos próprios, relacionados as particularidades de seu objeto de estudo. Segundo Matallo jr. (2011, p.30) "Os conceitos teóricos - que na maioria das vezes têm grande poder explicativo - constituem o cerne das teorias e as próprias conjecturas. [...]"

No escopo dessa pesquisa, optou-se pela definição de Arqueologia dada por Dunnell (2007), que nessa obra sinaliza que ela pode ser considerada uma ciência em relação à teoria formal, à sistemática e por apresentar conclusões passíveis de serem verificadas. $O$ autor a define como "[...] o estudo dos artefatos e das relações entre os artefatos, conduzidas em termos do conceito de cultura. [...]" (DUNNELL, 2007, p.152).

Melhor entendimento dessa definição de arqueologia se faz ao apresentar também os conceitos de cultura e de artefato. "Cultura" remete a "ideias compartilhadas", e "artefato", objeto de estudo exclusivo da arqueologia, refere-se a uma ocorrência qualquer, resultado da atividade humana e que apresente atributos físicos relacionados a sua localização no mundo tridimensional (DUNNELL, 2007).

A discussão sobre método é, certamente, a mais difícil de apresentar, visto a grande diversidade de "olhares" para o assunto. Entre os autores, há bastante divergência em relação à quantidade de métodos possíveis de serem empregados na atividade científica, bem como, há questionamentos relacionados a eficácia e validade de cada um deles. Segundo Carvalho (2000, p.3), para quem o método não se limita apenas a função de descrição de procedimentos escolhidos pelo pesquisador para se chegar ao resultado esperado,

[...] Quando se fala em método, busca-se explicar quais são os motivos pelos quais o pesquisador escolheu determinados caminhos e não outros. São estes motivos que determinam a escolha de certa forma de fazer ciência. Neste sentido, a questão do método é teórica (do grego theoria), uma vez que se refere aos pressupostos que fundamentam o modo de pesquisar, pressupostos estes que, como o próprio termo sugere, são anteriores à coleta de informações na realidade. 
Existiria, portanto, uma diferença entre "método de interpretação", que considera a concepção de mundo do pesquisador e "método de pesquisa", mais relacionado aos problemas operacionais da pesquisa (MORAIS; COSTA, 1984).

Ao longo da história, os métodos foram influenciados por distintas correntes de pensamento: empirismo, materialismo dialético, positivismo, fenomenologia e estruturalismo, e também, por marcos interpretativos, como a etnografia e o construtivismo (SAMPIERI; COLLADO; LUCIO, 2013). Logo, é importante que se faça a distinção destas categorias, não as confundindo com os métodos propriamente ditos.

Para Spósito (2004), "indução" e "dedução" não são métodos e sim procedimentos da razão, e o método é composto por elementos (base ideológica, teoria, leis, conceitos e categorias), os quais possibilitam uma leitura científica do mundo. Este autor identifica a existência de três métodos: o hipotético-dedutivo (onde o objeto estudado influencia o pesquisador, representado pela equação objeto > sujeito), o dialético (no qual ocorre a contradição e depois a "verdade" = sujeito $\leftrightarrow$ objeto) e o fenomenológico (onde o sujeito descreve o objeto e suas relações a partir do seu ponto de vista $=$ sujeito $>$ objeto). A partir da diferenciação feita por Morais e Costa (1984), essa classificação feita por Spósito se aproxima de uma concepção de "método de interpretação".

Quanto ao "método de pesquisa", remete-se, uma vez mais, ao trabalho de Dunnell (2007), no qual ele afirma que os métodos são ideativos (domínio das ideias) e não fenomenológicos (fenômenos físicos). "[...] Método deve ser entendido como significando um subsistema de uma teoria maior que é direcionado para a solução de um tipo particular de problema." (p.56).

Por fim, cabe ressaltar o cuidado que se deve ter para não confundir método com "técnica". Esta é definida por Dunnell (2007, p.59) como "[...] a aplicação de um método particular a um dado conjunto de fenômenos." E é

[...] através da técnica que o conteúdo se introduz na investigação, e, portanto, a técnica constitui o elo entre a teoria e os métodos de uma disciplina e os fenômenos que thes cabe organizar. [...] (DUNNELL, 2007, p. 58).

Ao procurar embasamento em teorias gerais das ciências arqueológica e geomorfológica para pesquisar o contexto arqueológico particular do Vale do Paraíba, 
supõe-se que o método empregado neste estudo é o hipotético-dedutivo, no qual o movimento do conhecimento se faz do geral para o caso particular.

\title{
2.1 A CIÊNCIA GEOMORFOLÓGICA E SEU OBJETO DE ESTUDO
}

Segundo Florenzano (2008, p.11) "[...] A Geomorfologia é a ciência que estuda as formas de relevo, sua gênese, composição (materiais) e os processos que nelas atuam." De acordo com Marques (2009, p. 23),

\begin{abstract}
As formas de relevo constituem o objeto de estudo da Geomorfologia. A existência desse objeto bem definido, com significativo e diversificado conteúdo a ser compreendido e explicado, a sistematização do conhecimento já atingido, o valor alcançado por suas concepções teóricas, o caráter prático da aplicação dos seus conhecimentos e a crescente importância que a sociedade Ihe tem conferido fazem com que a Geomorfologia venha sendo vista como uma ciência autônoma.
\end{abstract}

O relevo não deve ser entendido como uma unidade separada da paisagem, mas sim, considerado um elemento fundamental da mesma, que interage, influencia e é influenciado por outros fatores, tais como clima, solo, hidrografia, vegetação e seres humanos. Com a evolução das técnicas de manejo do meio ambiente, o homem tem aumentado seu potencial para modificar a superfície da Terra e alterar as formas do relevo, seja por meio da construção de uma rodovia, de uma barragem ou de um conjunto habitacional. Por outro lado, a má distribuição da renda força parte da população a ocupar áreas (formas de relevo) impróprias a moradia, como morros que são desmatados e tornam-se sujeitos ao desmoronamento, e planícies de inundação, que quando impermeabilizadas, tendem a causar enchentes.

Entender o funcionamento do relevo, complexo sistema existente entre a superfície terrestre e a atmosfera, que é controlado por forças endógenas (do interior da terra) e exógenas (energia solar), é também compreender os processos de erosão (desgaste) e de agradação (depósito) dos sedimentos. (ROSS, 2003; FLORENZANO, 2008; GUERRA; CUNHA, 2009).

As formas de relevo são classificadas quanto a sua morfologia, morfogênese, morfodinâmica e morfocronologia. A morfologia se divide em morfografia (aspectos descritivos ou qualitativos do relevo - plano, colinoso, montanhoso, etc.) e em morfometria (aspectos quantitativos do relevo - medidas de altura, comprimento, largura, volume, etc.). A morfogênese remete a origem das 
formas de relevo e ao seu desenvolvimento. A morfodinâmica interessa-se pelos processos ativos que atuam nas formas de relevo (endógenos e exógenos). E a morfocronologia trata do aspecto cronológico das formas de relevo (idade absoluta e relativa) (FLORENZANO, 2008).

Nesta pesquisa, cabe dar a definição das formas mais conhecidas (morfografia) - depressão, montanha, planalto e planície. De acordo com o novo dicionário geológico-geomorfológico de GUERRA \& GUERRA (2008), depressão corresponde a "área ou porção do relevo situada abaixo do nível do mar ou abaixo do nível da região que lhe estão próximas. [...]" (p.96); montanha se refere a "grande elevação natural do terreno com altitude superior a 300 metros e constituída por um agrupamento de morros. [...]" (p.219); planalto é "[...] superfície elevada mais ou menos plana delimitada por escarpas íngremes onde o processo de degradação supera os de agradação." (p.245) e planície é definida por "extensão de terreno mais ou menos plano onde os processos de agradação superam os de degradação. [...]" (p.247).

Por ser de interesse dessa pesquisa, trazemos ainda as definições de colina: "termo usado [...] para indicar pequenas elevações do terreno com declives suaves e inferiores ao outeiro ${ }^{1}$ [...]. São comumente aparentadas às montanhas, diferindo apenas no fato de estarem isoladas uma das outras, e com baixas altitudes." (GUERRA; GUERRA, 2008, p.146) e de morro: "monte pouco elevado, cuja altitude é aproximadamente de 100 a 200 metros. [...]." (GUERRA; GUERRA, 2008, p.440).

Ao se falar em cronologia em Geomorfologia, deve-se lembrar que a forma de relevo estudada hoje, de aspecto aparentemente estático, tem sua gênese em um paleoambiente dinâmico (BINFORD, 1983), caracterizado por um determinado paleoclima, uma forma de relevo e um tipo de terreno geológico pré-existentes. Há também que se destacar a importância dos estudos relacionados ao período geológico denominado Quaternário, visto que a maior parte das idades das formas de relevo se reportam a ele. O registro palinológico, preservado nos depósitos quaternários, bem como outros indicadores paleoambientais - cascalheiras e concreções lateríticas -

\footnotetext{
${ }^{1}$ Denominação dada aos pequenos morros cuja altitude média varia entre 50 e 100 metros. (GUERRA; GUERRA, 2008, p.457).
} 
constituem meios para a reconstrução dos paleoambientes (GUERRA; CUNHA, 2009).

Os terraços fluviais também são formas de relevo que interessam a esse estudo. São formados por aluviões antigos e em altitude superior a planície atual, também são indicadores cronológicos por viabilizarem a estratigrafia dos corpos aluviais (NOVO, 2008; GUERRA; CUNHA, 2009).

As grandes unidades de relevo podem ser classificadas com base na gênese (de origem interna ou externa). As forças internas da Terra, que influenciam na formação e alteração do relevo (em conjunto com as forças externas) provêm do movimento das placas tectônicas. Segundo a teoria da tectônica de placas, a litosfera seria formada por imensas placas que estariam "flutuando" sobre o manto e o choque entre elas ou o seu afastamento resultariam em atividade sísmica e vulcânica, formação de cadeias de montanhas, dobramentos, falhas e fossas oceânicas.

De acordo com Huggett (2003) apud Santos (2008), as placas também são classificadas em três tipos - interior (na região central do continente), marginal passiva ou marginal ativa (regiões onde as crostas continental e oceânica se encontram) -. As placas interiores dão origem as seguintes unidades de relevo: bacias, planaltos, rift valleys e vulcões intracontinentais. A esse estudo interessa particularmente a origem das bacias sedimentares intracratônicas, as quais serão melhor detalhadas posteriormente.

A temática da classificação de relevo sempre suscitou discussões, e até os dias atuais, há controvérsias em relação ao assunto. De acordo com Florenzano (2008), a dificuldade em estabelecer um padrão taxonômico para as formas de relevo advém do caráter complexo e variado dos objetos estudados pela Geomorfologia. Tal dificuldade de classificação reflete na inexistência de um método de mapeamento geomorfológico unificado que resolva os problemas da adequação da escala e da representação cartográfica (GUERRA; CUNHA, 2009; FLORENZANO, 2008).

Em um contexto arqueológico, o emprego da Geomorfologia se justifica por sua utilidade no entendimento das paisagens naturais. Logo, "estudar os processos dinâmicos do mundo moderno é uma base para o desenvolvimento de métodos para fazer inferências sobre restos estáticos de um passado distante." (BINFORD, 1983, p.55). 


\subsection{MÉTODOS EMPREGADOS EM GEOMORFOLOGIA}

Anterior a questão do mapeamento geomorfológico, julgou-se relevante discorrer sobre alguns pontos relacionados aos métodos empregados na Geomorfologia.

Segundo Ross (2003), entre os geomorfólogos, a questão do tratamento metodológico merece atenção, haja vista a confusão entre teoria e técnica. O método é, portanto, subproduto da teoria, de modo que ele norteia a pesquisa, enquanto as técnicas são o apoio. "[...] existem várias metodologias para a elaboração de cartas geomorfológicas, cada qual refletindo as diversas correntes teóricas ou pelo menos técnicas da disciplina." (ROSS, 2003, p.31.).

No Brasil, a metodologia em pesquisa geomorfológica é um tema que tem sido abordado com mais frequência, visto a utilidade do mapeamento geomorfológico nas atividades ligadas ao planejamento ambiental, do uso do solo urbano e rural, entre outros. Com relação ao estudo de relevos pretéritos, especialmente os referentes ao período Quaternário, Aziz Nacib Ab'Saber é alguém que não pode deixar de ser citado. Ao expor seu próprio conceito de Geomorfologia, este autor propõe ainda uma metodologia de pesquisa.

A proposta metodológica de Ab'Saber apresenta três níveis de tratamento em Geomorfologia: o primeiro trata da compartimentação topográfica regional e da caracterização e descrição das formas de relevo; o segundo menciona a obtenção de informações sistemáticas sobre a estrutura superficial das paisagens, por meio das quais relaciona as ideias de cronogeomorfologia e de processos paleoclimáticos e morfoclimáticos; e o terceiro discute o entendimento dos processos morfoclimáticos e pedogênicos atuais, bem como a compreensão da fisiologia da paisagem. (AB'SABER, 1969).

Esse e vários outros trabalhos de Ab'Saber, corriqueiramente citados por pesquisadores brasileiros da área - Ross (2003), Guerra e Cunha (2009) e Florenzano (2008) - são considerados como de grande relevância para o entendimento geomorfológico do território nacional, tanto por abordarem a problemática da classificação das formas de relevo, como por apontarem o caminho metodológico para as pesquisas em Geomorfologia. 
Ao ressaltar a importância do domínio da metodologia a ser aplicada durante o desenvolvimento de uma pesquisa, Ross (2003) também menciona a proposta metodológica apresentada por Libault (1971), que seria aplicável a diferentes segmentos da pesquisa (tanto às de natureza geográfica socioeconômica como às ciências naturais) e é constituída por quatro níveis, descritos a seguir.

O primeiro nível - compilatório - consiste, primeiramente, em obter dados. No caso da geomorfologia, eles podem ser obtidos por meio de

[...] cartas topográficas, cartas geológicas, observações efetuadas no campo sobre a estrutura superficial da paisagem, medições executadas no campo, declividades das vertentes, entalhamento dos canais de drenagem, ou dados gerados em estações experimentais. (ROSS, 2003, p.32).

Em seguida, faz-se a seleção dos dados mais significativos em meio ao grande número de dados coletados, e eles são compilados para se obter chaves de interpretação. Exemplos de informações importantes em pesquisa geomorfológica seriam: tipos de solo e litologia, paleossolos, paleopavimentos detríticos, depósitos de tipo aluvial ou coluvial, bem como dados de natureza morfométrica (níveis altimétricos, densidades de drenagem, declividade das vertentes e níveis de entalhamento dos canais de drenagem).

O segundo nível - correlativo - é a fase de correlação de dados homogêneos "de mesma natureza, obtidos no mesmo local, modo e momento." (ROSS, 2003, p.33). O terceiro nível - semântico - é interpretativo. "É, portanto, o momento de se conhecer leis, de se conhecer o mecanismo de funcionamento de um determinado fenômeno e de se poder estabelecer parâmetros que possibilitem sua aplicação." (Ibidem, p.34.). Essa fase possibilita a extrapolação dos resultados para áreas semelhantes às trabalhadas experimentalmente.

O quarto nível - normativo - tem duas funções: subsidiar a aplicação do produto da pesquisa e transformá-lo em modelo. "Essa modelização é representada através de cartogramas sínteses ou de gráficos que traduzem de forma mais simples e visual os produtos da pesquisa." (Ibidem, p.35.). Ao final da descrição da proposta de Libaut, Ross (2003) faz uma ressalva no sentido de que esta proposta seria melhor aplicada se as informações fossem trabalhadas com valores numéricos, o que viabilizaria tratamento estatístico. Portanto, quando aplicada em ciências da terra, 
seria necessário o emprego complementar de outros procedimentos metodológicos mais específicos.

Esta proposta metodológica não deixa dúvidas quanto a importância da cartografia na Geomorfologia, citada tanto no primeiro como no último nível. Porém, embora Florenzano (2008) afirme ser a cartografia um instrumento de análise e de síntese na pesquisa geomorfológica,

[...] Cabe destacar, ainda, a dificuldade na representação cartográfica de todas as informações geomorfológicas e, consequentemente, na leitura dos mapas (principalmente por parte de outros especialistas e planejadores). (FLORENZANO, 2008, p.105).

O problema em representar essas informações é devido a existência de diferentes parâmetros que podem ser considerados na elaboração de um mapa geomorfológico e do fato de que a escolha deles passa pelo viés da classificação das formas de relevo.

[...] os diferentes critérios (estrutural, climático, têmporo-espacial e genético) estabelecidos não superaram o problema lógico de classificação para a ciência geomorfológica, e, como salienta Hayden (1986), além dos problemas metodológicos e de conteúdo, a questão da escala apropriada, particularmente para mapas de grandes áreas em pequena escala, ainda não foi respondida. (CRISTOFOLETTI, 1980 apud FLORENZANO, 2008, p.125).

\subsection{CARACTERÍSTICAS DO MAPEAMENTO GEOMORFOLÓGICO}

Segundo Tricart (1965), são os níveis de representação do relevo, acima mencionados (morfologia, morfogênese, morfodinâmica e morfocronologia) que irão caracterizar os mapas geomorfológicos.

A metodologia do mapeamento geomorfológico baseia-se na "[...] ordenação dos fenômenos mapeados, segundo uma taxonomia que deve estar aferida a uma determinada escala cartográfica. [...]" (ARGENTO 2009, p.368). Logo, existe uma escala adequada para cada classe taxonômica: domínios morfoestruturais e regiões geomorfológicas - escalas iguais ou menores de 1:100.000 e unidades geomorfológicas - escala de 1:50.000.

Como o produto desta pesquisa será expresso em uma escala de 1:50.000, cabe ressaltar algumas características atribuídas as unidades geomorfológicas: 
[...] são definidas como um arranjo de formas fisionomicamente semelhantes em seus tipos de modelado. É aqui enfatizada a geomorfogênese através dos processos geradores e a similitude das formas é explicada por fatores paleoclimáticos e/ou por fatores associados à natureza dos domínios, principalmente aqueles expressos pelo comportamento da drenagem, seus padrões e anomalias e revelados pelas relações entre os ambientes climáticos atuais e subatuais e as condicionantes litológicas ou tectônicas. Nesse nível de detalhamento, são levadas em consideração as conotações fisiográficas e consideradas as interações dos elementos constituintes da paisagem como solo, clima e vegetação. (ARGENTO, 2009, pp.372-373).

Quanto aos elementos que deverão compor a legenda do mapa (aferida a mesma escala cartográfica), o autor menciona os tipos de drenagem (perene, intermitente), a presença de lagoas e de represamentos, a localização de anfiteatros, os terraços, as planícies fluviais, entre outros.

Atualmente, o mapeamento geomorfológico dispõe de variadas ferramentas para apoiá-lo, entre as principais destacam-se: o geoprocessamento, a cartografia computadorizada, o sensoriamento remoto e os SIG - Sistema de Informação Geográfica (ARGENTO, 2009).

É fundamental, no entanto, ter em mente que as modernas tecnologias disponíveis para a elaboração de mapeamentos temáticos, por si só, não garantem produto eficiente, já que elas servem, apenas, de apoio para melhorar a resolução do mapa final. Uma boa base conceitual em Geomorfologia, uma adequada escolha da legenda associada à escala cartográfica e, ainda, uma eficiente interpretação visual das formas de relevo e de seus respectivos processos geradores são condições que se transformam no alicerce fundamental para a elaboração de um bom mapeamento geomorfológico. (ARGENTO, 2009, p.384.).

Embora tenha se considerado importante caracterizar as etapas do mapeamento geomorfológico, ressalta-se que o produto final desta pesquisa será apresentado na forma de um mapa que representará algumas formas específicas do relevo: colinas ou morros, terraços e depressões.

\subsection{A GEOARQUEOLOGIA COMO ABORDAGEM TEÓRICA}

O caráter interdisciplinar da Arqueologia é refletido tanto em sua base teórica como nos métodos por ela adotados. Desde que "nasceu", a princípio como disciplina auxiliar da História e, posteriormente, quando se firmou enquanto ciência sistematizada, a Arqueologia utiliza-se de "ferramentas" de outras ciências (Antropologia, Etnologia, Sociologia, Geologia, Geografia, Biologia, entre outras). 
Essa habilidade ou necessidade de se relacionar com outras áreas do conhecimento favoreceu o surgimento da Geoarqueologia, a qual por uns é vista como um campo de estudo na pesquisa arqueológica, uma "subdisciplina", tal como a Zooarqueologia, a Arqueobotânica ou a Arqueometria. E por outros, é apresentada como uma "abordagem", componente essencial e indispensável da investigação arqueológica.

De qualquer forma, o emprego da Geoarqueologia é sempre justificado pela necessidade do uso de métodos e técnicas das Ciências da Terra, no estudo da formação do registro arqueológico (BUTZER, 1982; GLADFELTER, 1977; HASSAN, 1979 apud AFONSO, 2008).

Independentemente do modo como a Geoarqueologia é vista, ora como uma subdisciplina (BITENCOURT, 2008; AFONSO, 2008; KASHIMOTO; SALLUN; SUGUIO, 2008), ora como uma abordagem (ARAUJO, 1999), ressalta-se aqui a sua importância, integrada a Geomorfologia, no contexto de uma investigação arqueológica com ênfase em sítios Paleoíndios.

Pesquisas realizadas a partir de uma abordagem geoarqueológica têm sido publicadas no Brasil com mais frequência nos últimos anos (RUBIN; SILVA, 2008; 2013) e têm revelado resultados interessantes que comprovam a eficácia da integração de dados geomorfológicos, pedológicos, geoquímicos, hidrológicos, entre outros, no estudo de diferentes tipos de sítios arqueológicos. O uso destes dados integrados para o conhecimento prévio das características gerais do ambiente no qual já é conhecida a ocorrência de artefatos, bem como seu potencial para tal, é enfatizado por autores da área

\footnotetext{
Enquanto a geomorfologia procura melhor conhecer o passado e desenvolver meios e formas precisas de situar suas descobertas no tempo, os geoarqueólogos engajam-se no estudo de antigas áreas de ocupação humana com o apoio de reconhecimento de campo e reconhecimento indireto por fotografias aéreas para desenvolvimento posterior de pesquisas de campo, análises de laboratório e construção de modelos (COLTRINARI, 2008, p.17).
}

A aplicação do termo "geoarqueologia" surge na década de 1970 (BITENCOURT, 2008; AFONSO 2008; KERN; COSTA; RUIVO, 2008), por meio da publicação de diversos trabalhos (BUTZER, 1975; GLADFELTER, 1977; HASSAN, 1979 apud BITENCOURT, 2008) e (RENFREW, 1976 apud AFONSO, 2008). A princípio, estudos geoarqueólogos são desenvolvidos na Europa e na América do 
Norte. No Brasil, passam a ser identificados com esse "rótulo" na década de 1980, a partir de artigos, teses e dissertações (AFONSO, 2008).

Uma abordagem geoarqueológica voltada para estudos de ambientes tropicais, no entanto, tende a ser distinta da praticada no norte da América e na Europa, ambos localizados na Zona Temperada do Norte. A relevância de estudos paleoambientais regionais tropicais é mencionada, por exemplo, nos estudos a respeito da geoarqueologia de ambientes fluviais no Alto Rio Paraná

Considerando-se que cada sítio arqueológico é único em sua composição sedimentológica, inserção paisagística e práticas culturais que nele se manifestaram, a metodologia de análise desses sítios e contextos arqueológicos regionais não poderia desconsiderar essas especificidades. (KASHIMOTO; SALLUN; SUGUIO, 2008, p.109).

E também é abordada por Araujo (2013) em seu trabalho "Geomorfologia e paleoambientes no leste da América do Sul: implicações arqueológicas", no qual são relacionadas as mudanças climáticas globais (principalmente o Último Máximo Glacial - UMG), bem como os indicadores paleoambientais à ocorrência de sítios e de sinais arqueológicos em ambientes tropicais e subtropicais. Por meio da Geoarqueologia, ou melhor, de uma abordagem geo-informada, o autor discute alguns procedimentos de pesquisa que podem ser empregados, levando-se em conta os tipos de paleoambientes predominantes nas áreas de interesse, assim como os processos geomórficos a serem considerados no passado e no presente.

O emprego da Geoarqueologia na investigação de sítios Paleoíndios é ainda justificado pelo caráter cronológico deles:

\footnotetext{
Um aspecto interessante da arqueologia do período Paleoíndio é que ela tem que se basear ainda mais em geoarqueologia, não só porque os sítios muitas vezes são compostos apenas por rochas, mas também porque eles têm feito parta da litosfera por um longo tempo (ARAUJO, 2013, p.162-163).
}

E para aumentar o sinal arqueológico, Araujo (2013) também propõe a análise de microartefatos (em campo e no laboratório) e da presença de carvões e de pólen, encontrados no solo, em terraços fluviais ou no fundo de lagoas.

Estudos palinomórficos, efetuados na Região do Vale do Paraíba, têm demonstrado que a turfa encontrada nesta região apresenta idades recuadas. Esse tipo de informação paleoambiental é relevante por possibilitar aos pesquisadores fazerem inferências sobre os climas passados que perduraram nestes locais, bem 
como sobre o desenvolvimento de algumas formas de relevo, como das depressões, por exemplo. Tais dados serão discutidos mais detalhadamente posteriormente.

Devido a sua relevância na formação do arqueólogo, é desejável que a Geoarqueologia faça parte da grade curricular dos cursos superiores ou de pósgraduação em Arqueologia. A respeito dessa proposição, Goldberg (2008) cita os benefícios que um "olhar" geoarqueológico pode trazer a pesquisa arqueológica, principalmente, no sentido de identificar em campo as relações entre os depósitos sedimentares (sua composição, textura, forma de organização) e os artefatos, bem como entender o contexto ao qual estão associados.

Para este autor, os estudantes de Arqueologia deveriam ser treinados, a partir de mais experiência em campo e em laboratório, em habilidades que lhes aumentasse a capacidade de examinar dados da paisagem regional que são pertinentes ao sítio estudado. Tal competência, acompanhada de outras como a capacidade de interpretar cartas geológicas, fotografias aéreas, imagens de satélite, de utilizar uma estação total, ou seja, de usar a tecnologia a seu favor para obter informações (relativas a matéria prima, sistemas de drenagem, idade da paisagem, recursos hídricos e potencial geológico), resulta também em economia de tempo e de recursos financeiros.

Outro ponto fundamental para quem está em campo diz respeito a reflexão, constante, sobre a formação do sítio, pois é importante pensar sobre o que se escava e evitar fazê-lo de forma mecânica. Assim, detalhes como os materiais utilizados na construção das estruturas (como pisos, por exemplo) não devem ser ignorados, por revelarem informações sobre as atividades humanas também. (GOLDBERG, 2008).

\subsection{O "FATOR GEO” NA INVESTIGAÇÃO DE SÍTIOS ARQUEOLÓGICOS}

Um ponto importante, que deve ser considerado na compreensão das paisagens do passado e para a tentativa de recompô-las é o fator geo, pois o entendimento da paisagem ao redor de um sítio facilita a reconstrução do passado cultural (MORAIS, 1999). A partir da relação de sítios arqueológicos conhecidos no Vale do Paraíba, faz-se aqui uma tentativa de entender sua localização, bem como parte de seu sistema de funcionamento, baseando-se em fatores fisiográficos 
observáveis atualmente e, supostamente, semelhantes aos encontrados pelas populações passadas.

O fator geo "trata-se de um foco de preocupações centrado no conjunto intersecção entre a arqueologia, a geografia, a geomorfologia e a geologia." (MORAIS 1999-2000, p.212), distribui em dois "subcampos" da arqueologia (arqueologia da paisagem e geoarqueologia) e pode ser desdobrado em subtemas, conforme a escala de abordagem (macro ou micro). Assim, de acordo com Morais (1999), nas macroescalas ele é percebido, por exemplo, nos estudos: genéricos relativos às formas de relevo; geomorfológicos, com a identificação dos compartimentos do relevo do entorno de ambientação; geológicos, com a identificação e descrição das formações geológicas do entorno de ambientação, suas características estratigráficas e sedimentares; ambientais com a definição e descrição de zonas arqueo-ambientais, considerando os dados $\mathrm{e}$ as inter-relações previstas no macro-nível; topomorfológicos; tecnológicos de artefatos (líticos e cerâmicas); de conservação e preservação ligados a sítios específicos ou sistemas locais e de datações (geocronologia), com coletas locais de amostras passíveis de datações radiométricas.

Outros subtemas desdobrados do fator geo, em abordagens no micro-nível, são: análises pedológicas, para confirmar a delimitação dos núcleos de solo antropogênico; análises geomorfológicas no âmbito do sítio; estudos microestratigráficos; análises sedimentológicas locais; análises tecnológicas de artefatos líticos e cerâmicos, com a finalidade de elucidar as técnicas de manufatura, bem como as fontes de matérias-primas disponíveis no âmbito do modelo cadeia operatória; construção de modelos regionais a partir das situações locais; obtenção de datações radiométricas (geocronologia): carbono 14 e termoluminescência. (MORAIS, 1999).

\subsection{A ABORDAGEM MATERIALISTA EM ARQUEOLOGIA}

O objetivo desta discussão é ressaltar a preocupação, por parte da autora, sobre o corpo teórico no qual acredita se basear este estudo. Porém, considera-se que a adoção de uma determinada linha teórica não, necessariamente, impede que sejam consideradas outras formas de explanação para os problemas de pesquisa. A publicação de novos dados sobre o objeto de estudo, passível de ocorrer durante o 
período de desenvolvimento de um projeto de pesquisa, sempre que possível, deve ser discutida e incorporada à redação final.

Além da apreensão de conceitos concernentes a sua área do conhecimento, que se dá por meio da revisão bibliográfica e da discussão com colegas, professores e outros pesquisadores, a reflexão sobre os paradigmas vigentes, por parte do autor, também deve ser considerada no processo da produção do conhecimento. Ter a consciência de que todos que se propõem a fazer pesquisa científica são influenciados pela "estrutura teórica aceita em vigência", bem como ter a capacidade de questioná-la quando os resultados não condizem com ela, fazem parte do processo de amadurecimento do pesquisador.

Neste estudo, devido à natureza das perguntas de pesquisa, optou-se pela aproximação com uma abordagem teórica materialista, relacionada a "fase" processualista da Arqueologia. As correntes teóricas em Arqueologia foram sendo sucedidas por outras, porém, a aparição de uma não elimina a anterior, de modo que elas coexistem. As principais características do processualismo, no qual, os aspectos materiais da cultura são ligados aos meios de produção, podem ser observadas na obra "Working at Archaeology", de Lewis R. Binford, lançada em 1983. Em um de seus capítulos, "The Archaeology of the Place", o autor destaca o deslocamento de grupos humanos pela paisagem e a consequente variabilidade cultural, por meio da diversidade de atividades realizadas em um mesmo "lugar" em momentos diferentes. Ele menciona tipos diferentes de "sítios" ou de "agrupamentos", pois o material arqueológico pode estar entre os sítios, e não somente dentro deles.

Quanto ao conceito de cultura, acima definido por Dunnell (2007) como ligado as ideias compartilhadas, Binford concorda com a definição de White (1957), para quem cultura é um meio extra somático de adaptação (White, 1959 apud Binford, 1983a). Para o autor, a capacidade de adaptação ao meio ambiente (estático) está diretamente ligada a habilidade de se comportar racionalmente, ou seja, de desenvolver técnicas para facilitar a aquisição de recursos materiais. O ambiente é visto como estático, no qual o homem terá que se adaptar por meio do mínimo gasto de energia e máximo proveito dos recursos. Entre outras particularidades da Arqueologia Processualista, destacam-se ainda a construção dos modelos e a sua tendência materialista. De acordo com Binford (1983a, p.357) "Archaeological must begin their analyses on materials remaining at archaelogical sites." 


\subsection{O SURVEY ARQUEOLÓGICO}

Existem outros autores que corroboram com esta tendência para a identificação de material arqueológico "fora dos sítios". Achá-los implica em considerar também procurá-los de forma diferente. Dancey (1974), ao apontar as vantagens em realizar um tipo de prospecção arqueológica de forma sistemática, elenca cinco regras a serem seguidas: 1) inspeção da superfície por artefatos, não sítios; 2) pegar amostra da diversidade ambiental da área de prospecção; 3) trabalhar com unidades explicitamente definidas; 4) cobrir o chão em um curso padronizado e 5) registrar a localização exta em todos os casos possíveis.

Segundo Foley (1981), para o estudo da formação do registro arqueológico, a estrutura de "sítio" não é satisfatória, visto que ele está espalhado de forma contínua. E de acordo com Dunnell e Dancey (1983), a rigidez da definição de sítio, limitando-o a áreas específicas implica na possibilidade de se ignorar material arqueológico localizado "fora" delas, sendo recomendado a adoção de uma estratégia de coleta de dados em escala regional.

Esse tipo de abordagem é interessante para esta pesquisa pois sua proposta não se restringe a ideia de construir um mapa de localização de sítios arqueológicos, mas sim, o de apontar áreas de potencial arqueológico. Esses locais de maior preferência ao assentamento humano teriam sido escolhidos com base na proximidade de recursos, o que acarretaria em menor dispêndio de energia para consegui-los, tal como apontado por Binford (1983).

\subsection{O USO DE MODELOS PREDITIVOS NA PESQUISA ARQUEOLÓGICA}

Nesta pesquisa, foram realizados muitos procedimentos que são corriqueiros durante a aplicação de um modelo preditivo, porém, não se considera que este tenha sido o foco do estudo. De acordo com alguns autores, Kipnis (1997), Thomaz (2002), Nazareno (2005), Oliveira, Bartolomucci e Rodriguez (2005), Kneip e Mello (2012), Silva, Rosa e Luz (2012) e Barioni (2013), modelos preditivos podem ser empregados para apontar áreas de maior concentração de material arqueológico ao se integrar informações sobre as variáveis ambientais com dados etno-históricos de 
ocupação. O cruzamento de tais dados normalmente é feito por meio do uso de parâmetros estatísticos, processados com o auxílio de um SIG.

Segundo Kipnis (1997, p.1)

[...] O desenvolvimento de modelos preditivos [...] tem por objetivo prever a ocorrência de um determinado fenômeno arqueológico a partir do conhecimento prévio das variáveis envolvidas na formação dos padrões arqueológicos, segundo uma perspectiva sistêmica.

Em seu artigo, este autor faz um breve histórico do desenvolvimento e da utilização de modelos preditivos em arqueologia, associando-os à projetos de impacto ambiental na América do Norte.

A utilização de modelos preditivos nos Estados Unidos teve um grande
avanço no final da década de 70 e início da década de 80 através de projetos
financiados por agências governamentais que gerenciam as terras federais
norte americanas. O objetivo destes projetos era o desenvolvimento de
modelos que poderiam indicar locais de ocorrência de recursos arqueológicos
em grandes áreas, baseados em amostras obtidas através de prospecções
feitas somente em algumas partes da região (Ambler, 1984, Ebert 1988,
Kvamme 1990, Kohler and Parker 1986, Warren 1990). Em outras palavras,
levantar subsídios para avaliação dos impactos culturais e desenvolvimento
de programas de mitigação dos impactos negativos de um modo eficiente e
sem custos abusivos. (KIPNIS, 1997, p.5).

Ainda segundo Kipnis (1997), são três os elementos comuns aos modelos preditivos, informação, método e resultado. Quanto ao método, é usado para "[...] transformar informação em resultados previsíveis. [...]. (p.6)." E a "[...] Informação é o conjunto do conhecimento já existente do qual o modelo é derivado. [...]." (p.6).

A maior parte dos estudos mencionados está relacionada às tentativas, dentro do âmbito dos estudos arqueológicos necessários ao licenciamento ambiental, de amenizar os custos da cobertura de áreas extensas e assim, tornar o processo mais eficiente.

Um dos pioneiros no país a discutir a ideia de modelos preditivos é José Luiz de Morais. Segundo o autor, a adoção do fator geo

[...] pode colaborar vivamente na organização de um modelo preditivo baseado na definição de parâmetros locacionais (percebidos em um modelo empírico), de extrema utilidade para o mapeamento de áreas potencialmente favoráveis para a localização de sítios arqueológicos. (MORAIS, 1999-2000, p.212-213). 
Com exceção dos estudos de Silva, Rosa e Luz (2012) e de Barioni (2013), nos demais, não são mencionadas prospecções arqueológicas de superfície ou subsuperfície para comprovar a existência de material arqueológico nos locais indicados pelos mapas preditivos. Porém, pelo que entendemos da leitura dos mesmos, o objetivo foi o de compará-los com as áreas nas quais já haviam sido registrados sítios arqueológicos.

O estudo de Barioni (2013) abrangeu o Complexo Hidrelétrico de Belo Monte, no estado do Pará, municípios de Vitória do Xingu, Altamira e Brasil Novo. A partir do cruzamento de dados dos mapas pedológico e geomorfológico da área pesquisada, foram identificadas as áreas mais apropriadas para a prospecção arqueológica. Segundo o autor,

\footnotetext{
O desenvolvimento da Carta de Suscetibilidade Arqueológica, só pode ser feito, após a realização das primeiras sondagens na área. [...] Essas sondagens foram realizadas em polígonos, os quais por sua vez, foram distribuídos em áreas que atendessem a todas as classes de relevo e solo e consequentemente, foram encontrados 73 sítios arqueológicos em praticamente todos os tipos de relevo e solo [...]. (BARIONI, 2013, p.22).
}

Após, foram geradas duas tabelas relacionando a distribuição dos sítios arqueológicos nos mapas geomorfológico e pedológico. A tabela com dados pedológicos mostra o ranque de potencial arqueológico e a ocorrência de sítios. Foram computados 9 sítios em Cambissolo, 60 em Argissolo, 3 em Neossolo e 1 em Espodossolo. Os dados geomorfológicos são apresentados na tabela 1.

A respeito dos dados da tabela de solos, o autor afirma que há discrepância entre a área apontada como de maior potencial arqueológico e a ocorrência de sítios arqueológicos 
Tabela 1 - Ranqueamento dos Sítios Arqueológicos com base na Geomorfologia local

\begin{tabular}{|c|c|c|c|c|}
\hline Tipo de Relevo & Área (ha) & $\begin{array}{c}\text { Número de sítios } \\
\text { encontrados }\end{array}$ & $\begin{array}{c}\text { Frequência Espacial } \\
\text { ha/sítio }\end{array}$ & Ranque \\
\hline Planície Fluvial & 26645,8 & 14 & 1903,2 & 1 \\
\hline $\begin{array}{c}\text { Colinas médias e } \\
\text { pequenas }\end{array}$ & 155246,9 & 41 & 3786,5 & 2 \\
\hline Morrotes e Morros & 100853,9 & 13 & 7760,0 & 4 \\
\hline Morrotes & 17743,8 & 5 & 35548,7 & 5 \\
\hline Colina média & 78581,3 & 0 & 0 & 5 \\
\hline Terraços & 7178,3 & 0 & 0 & 5 \\
\hline
\end{tabular}

Fonte: extraído de Barioni (2013).

Por fim, foi gerado um mapa final (figura 1) apenas com as classes mais altas para pedologia (Cambissolo) e geomorfologia (Planícies Fluviais) e são apresentadas as conclusões:

Na observação do detalhe do mapa (figura 7) é possível cotejar que as áreas destacadas no mesmo, são aquelas que ocorrem à interseção do Cambissolo com as Planícies Fluviais assim como durante as prospecções arqueológicas foi possível notar a ocorrência de apenas duas zonas de ocupação pretérita nessas áreas. Dessa forma é possível indicar, para futuros trabalhos, uma redução na malha de prospecção nessas áreas. (BARIONI, 2013, p.26).

Figura 1 - Mapa de potencial arqueológico

Areas de mailor potencial arqueológico

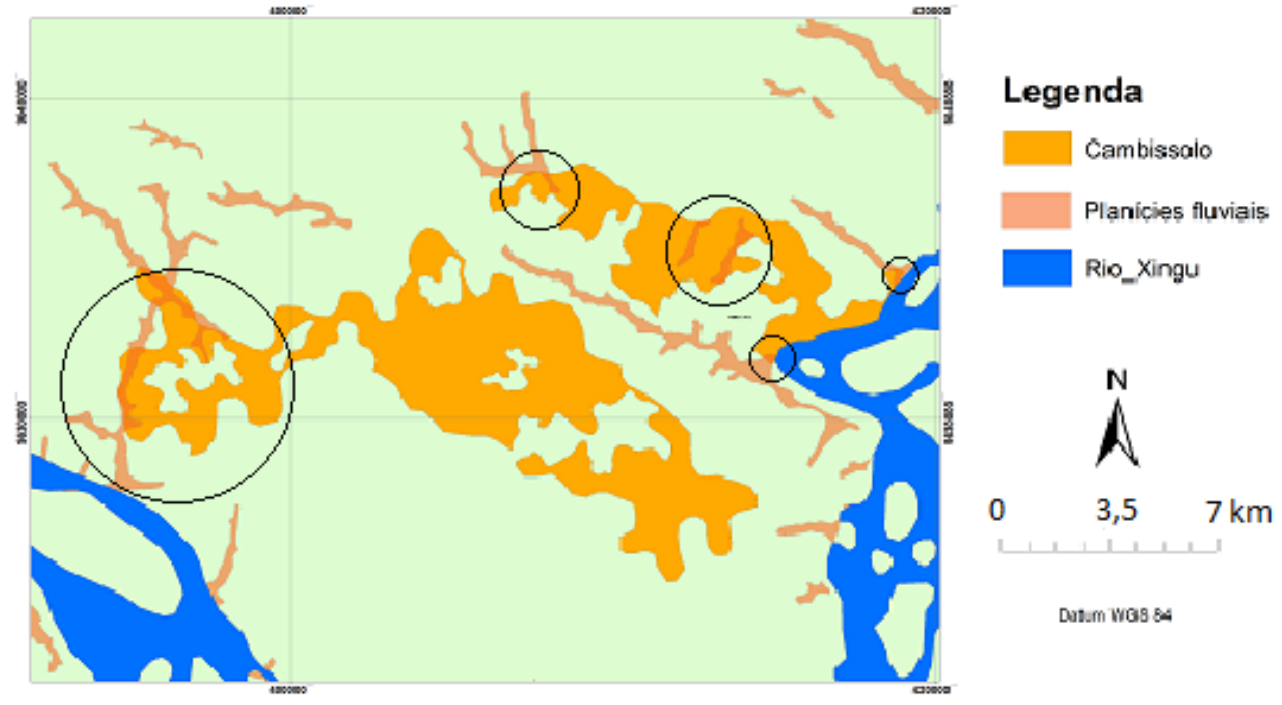

Fonte: extraído de Barioni (2013). 
A carta de sensibilidade arqueológica apresentada por Silva, Rosa e Luz (2012), foi elaborada no âmbito do Programa de Gestão do Patrimônio Arqueológico, Histórico e Cultural da UHE Jirau, em Rondônia, com o objetivo de orientar as prospecções arqueológicas. Após a escolha de uma área sem dados de sítios arqueológicos cadastrados, a partir de critérios geológicos (fonte de matéria-prima), geomorfológicos (preferência por lugares para habitar, lascar e áreas sujeitas à processos erosivos e deposicionais) e hidrográficos (proximidade de canais fluviais), elaborou-se uma carta inicial que apontou zonas de baixa, média e alta sensibilidade arqueológica. O passo seguinte foi a execução do trabalho de campo nessas áreas, por meio de sondagens com duas classes de equidistância, 50 e 100 metros, com cavadeira manual articulada, a uma profundidade de $120 \mathrm{~cm}$. Do cruzamento dos dados de gabinete e de campo, elaborou-se nova carta de sensibilidade (vide figura 2).

Figura 2 - Mapa de classes de probabilidade de ocorrências arqueológicas.

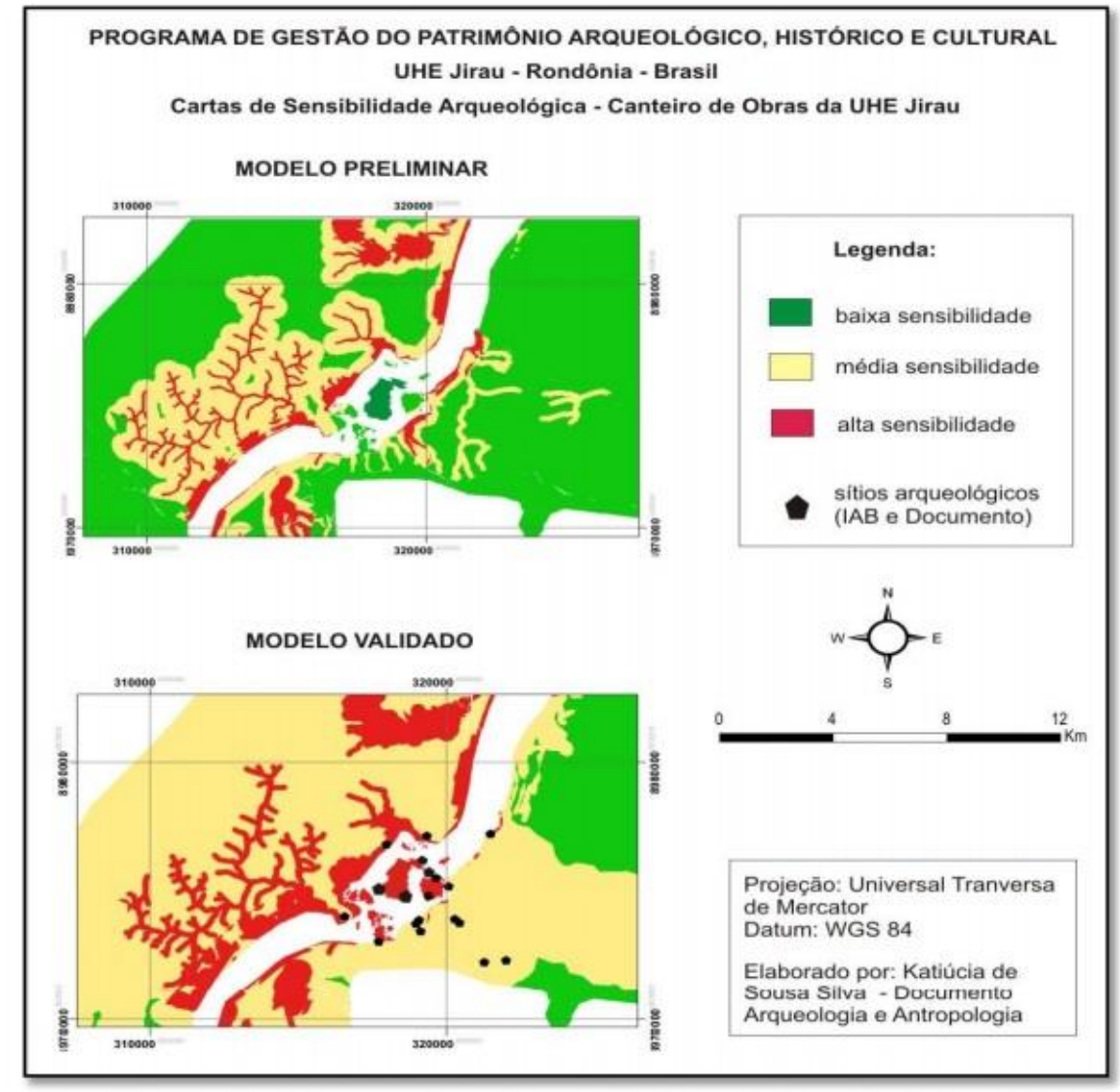

Figura 4 - cartas de sensibilidade arqueológica para o Canteiro de Obras da UHE Jirau.

Fonte: Extraído de Silva, Rosa e Luz (2012). 
Quanto aos resultados das prospecções e considerações finais, os autores afirmaram que

No Canteiro de Obras da UHE Jirau foram abertos 11.800 poços-teste em uma área de 2.514 hectares no modo de prospecção intensiva; e 2.493 poços-teste cobrindo 4.087 hectares aplicando a malha extensiva. No setor de desvio do rio Madeira, 12 ha foram alvo de prospecção visual, totalizando 6.613 ha pesquisados. A detecção de sítios arqueológicos suscitou a reformulação da carta, de modo a refletir os resultados obtidos em campo através da revaloração de pesos atribuídos a cada unidade de geomorfologia, geologia e distância de rios. Os sítios prospectados pela Documento Arqueologia e Antropologia Ltda. totalizam o número de nove (entre cerâmicos, líticos e um sítio histórico). [...]. (SILVA; ROSA; LUZ, 2012, p.271).

A análise dos sítios arqueológicos encontrados no canteiro de obras da UHE Jirau demonstra que a posição desses sítios na paisagem não é aleatória. $O$ fato desses sítios localizarem-se a poucos metros de cursos fluviais (geralmente sobre terraços) provavelmente relaciona-se diretamente com o aproveitamento desse recurso para a sobrevivência (notadamente para a pesca) de populações pré-coloniais, bem como a disposição dos locais de assentamento em locais à salvo de cheias periódicas. [...]. (SILVA; ROSA; LUZ, 2012, p.276-277)

A revisão dessas obras demonstra que o uso de modelos preditivos em arqueologia pode ser bastante eficiente se realizado de forma sistemática. Constituise de uma técnica adequada para a cobertura de áreas extensas, nas quais é preciso propor a estratificação do terreno, devido a inviabilidade de se prospectar a área total. E embora, os casos mencionados sejam oriundos de pesquisas arqueológicas realizadas por empresas para fins de licenciamento ambiental, acredita-se que seja aplicável para projetos de pesquisas acadêmicas também. 


\section{CARACTERIZAÇÃO DA ÁREA DE ESTUDO}

Neste tópico estão apresentados os aspectos físicos da área de estudo e sua localização. Por ser de grande relevância para o estudo, uma breve explanação sobre a gênese das bacias sedimentares também foi incluída.

\subsection{LOCALIZAÇÃO}

O recorte espacial da pesquisa foi estabelecido de acordo com os limites de um município da região, segundo sua carta topográfica, produzida pelo IBGE, em 1988. Em virtude de sua posição geográfica, no centro do Vale, bem como sua extensão territorial e consequente variedade de feições morfológicas interessantes a esse estudo (depressões, terraços e colinas), Pindamonhangaba foi o município escolhido. Sua escolha ainda foi influenciada pela observação de sua ausência na relação apresentada por Lopes (2014), de outros municípios da região, situados na mesma bacia sedimentar, nos quais constam registros de achados fortuitos e sítios arqueológicos relacionados a sítios pré-coloniais.

Parte-se do pressuposto de que os povos pré-coloniais estavam circulando na região, vindos do litoral em direção ao Planalto Sudeste e vice-versa. E a identificação de material arqueológico nos municípios vizinhos reforçaria a suposição da existência do mesmo em Pindamonhangaba, porém, ainda não encontrado. $O$ fato da autora ser natural deste município, conhecer a região e ter contatos que facilitariam o desenvolvimento da pesquisa, especialmente, quanto as autorizações necessárias para conhecer as propriedades e realizar os trabalhos de campo, também foi considerado.

A carta topográfica de Pindamonhangaba abrange porções dos territórios de outros quatro municípios limítrofes: Roseira, Potim, Guaratinguetá e Aparecida, além de mostrar uma pequena porção do município de Taubaté, apenas onde o rio Una faz a divisa natural entre os municípios.

O município de Pindamonhangaba (vide figura 3) localiza-se no estado de São Paulo, no eixo São Paulo - Rio de Janeiro, uma das regiões mais industrializadas do país. Sua área territorial de $731,90 \mathrm{Km}^{2}$ distribui-se entre o distrito de Moreira 
César, com $213 \mathrm{Km}^{2}$, a área urbana com 176,45 $\mathrm{Km}^{2}$ e a área rural com $342,45 \mathrm{Km}^{2}$ (FERREIRA, 2007).

Figura 3- Localização do município de Pindamonhangaba, estado de São Paulo.

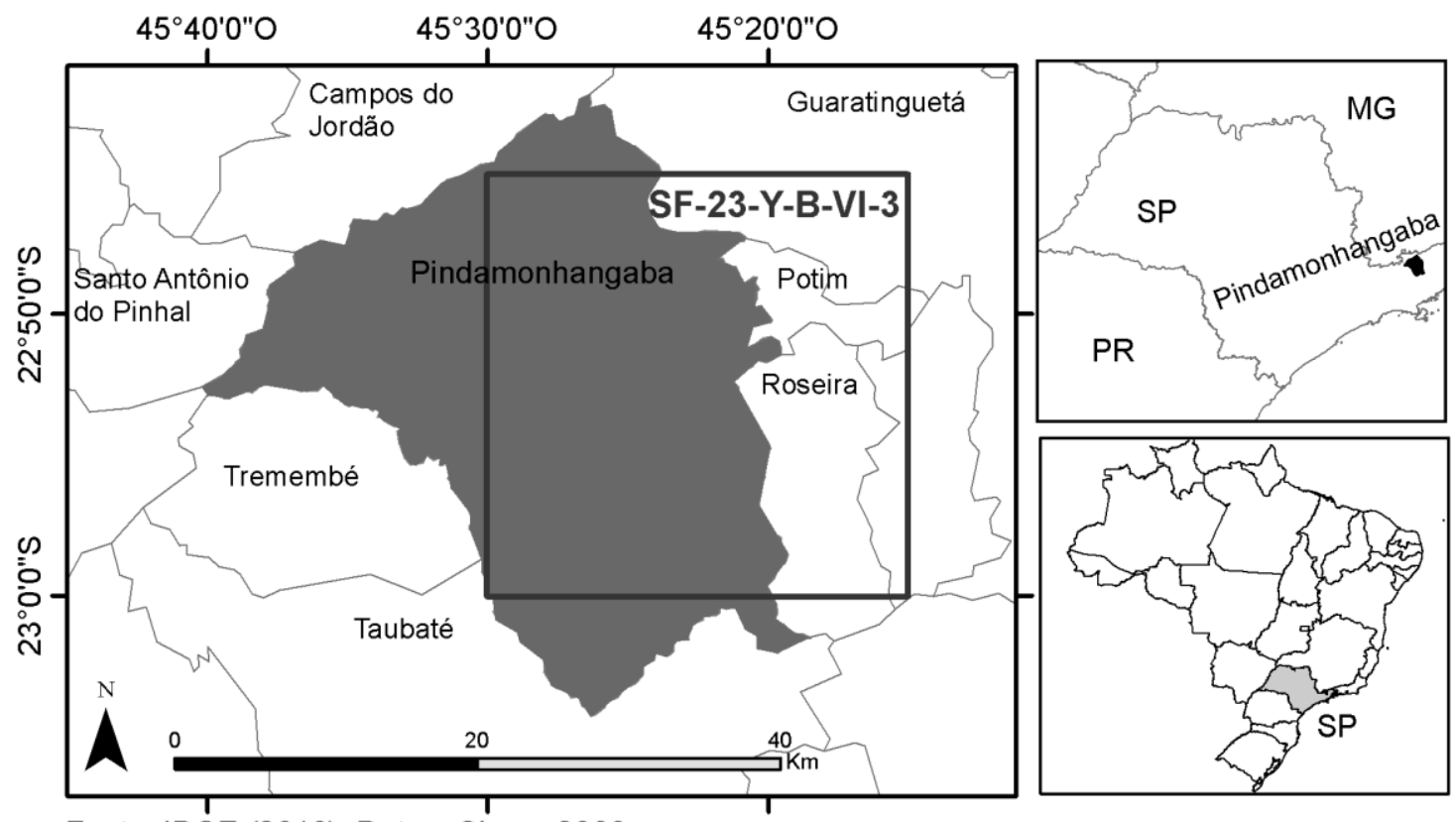

Fonte: IBGE (2010). Datum Sirgas 2000

\subsection{A COBERTURA VEGETAL}

De acordo o Mapa Florestal dos Municípios do Estado de São Paulo Pindamonhangaba, desenvolvido pelo Instituto Florestal do Estado de São Paulo, a cobertura vegetal deste município é constituída, e distribuída em relação a área territorial total nas seguintes proporções, por: $8.923,01$ ha $(11,96 \%)$ de mata, 5.518,46 ha $(7,40 \%)$ de capoeira, 2,02 ha $(0,00 \%)$ de vegetação de várzea e $3.221,49$ ha $(4,32 \%)$ de reflorestamento.

A bacia do Rio Paraíba possui $3.846 \mathrm{~km}^{2}$ de vegetação natural remanescente. As categorias de maior ocorrência são Floresta Ombrófila Densa, Floresta Estacional Semidecidual e Floresta Ombrófila Mista (SÃO PAULO, 2017). De acordo com informações disponibilizadas no portal do Ministério do Meio Ambiente, 
A Mata Atlântica é formada por um conjunto de formações florestais (Florestas: Ombrófila Densa, Ombrófila Mista, Estacional Semidecidual, Estacional Decidual e Ombrófila Aberta) e ecossistemas associados como as restingas, manguezais e campos de altitude, que se estendiam originalmente por aproximadamente $1.300 .000 \mathrm{~km} 2$ em 17 estados do território brasileiro. Hoje os remanescentes de vegetação nativa estão reduzidos a cerca de $22 \%$ de sua cobertura original e encontram-se em diferentes estágios de regeneração. Apenas cerca de $8,5 \%$ estão bem conservados em fragmentos acima de 100 hectares. (MMA, s/d, p.1).

A importância deste bioma também está na diversidade de espécies vegetais: cerca de 20.000 (35\% das existentes no país), inclusas espécies endêmicas e ameaçadas de extinção. A fauna é composta de 849 espécies de aves, 370 de anfíbios, 200 de répteis, 270 de mamíferos e 350 de peixes. (MMA, s/d, p.1).

Duas APAS - Áreas de Proteção Ambiental estão dentro dos limites territoriais do município: Área Ambiental da Bacia do Rio Paraíba do Sul e Área de Proteção Ambiental da Serra da Mantiqueira, além do Parque Natural do Trabiju, uma Unidade de Conservação de Proteção Integral (PINDAMONHANGABA, 2016).

\subsection{ASPECTOS CLIMÁTICOS}

O clima predominante no Vale do Paraíba é o tropical, com verão quente e chuvoso e inverno seco e pouco frio. As temperaturas médias anuais variam entre $18^{\circ} \mathrm{C}$ e $28^{\circ} \mathrm{C}$, com mínimas, no inverno de $11^{\circ} \mathrm{C}$ e máximas, no verão, próximas de $31^{\circ} \mathrm{C}$. A média anual de umidade relativa do ar é de $76 \%$ e as maiores precipitações (70\% do total anual) ocorrem de novembro a março. Os índices de precipitação anual oscilam entre $1.200 \mathrm{~mm}$ e $1.400 \mathrm{~mm}$ (FERREIRA, 2007).

\subsection{ASPECTOS GEOLÓGICOS E GEOMORFOLÓGICOS}

De acordo com a ordem taxonômica proposta por Ross e Moroz (1997), o estado de São Paulo está compartimentado em três unidades morfoestruturais: Cinturão Orogênico do Atlântico, Bacia Sedimentar do Paraná e Bacias Sedimentares Cenozóicas. Individualizadas a partir das unidades morfoestruturais, têm-se as unidades morfoesculturais. A área de estudo se insere na primeira e na última unidade morfoestrutural mencionada. O Cinturão Orogênico do Atlântico compreende a 
Unidade Morfoescultural Planalto Atlântico que abrange, entre outras, as unidades de relevo regional Planalto e Serra da Mantiqueira, Planalto de Paraitinga / Paraibuna e Planalto do Médio Vale do Paraíba. Na unidade morfológica denominada Planalto e Serra da Mantiqueira

[...] predominam formas de relevo denudacionais cujo modelado constitui-se basicamente em escarpas e morros altos com topos aguçados (Da) e topos convexos (Dc). No nível alto do Planalto da Mantiqueira predominam altimetrias entre 1.000 e $2.000 \mathrm{~m}$ e as declividades predominantes são superiores a $30 \%$ e frequentemente acima de $60 \%$. No nível médio, as altimetrias variam de 700 a $1.000 \mathrm{~m}$ e as declividades entre 20 e $30 \%$. [...] Por ser uma unidade de relevo onde as formas são muito dissecadas, com vales muito entalhados e com alta densidade de drenagem e vertentes muito inclinadas, esta área foi identificada com um nível de fragilidade potencial muito alto, estando, portanto, sujeita aos processos erosivos intensos e grande probabilidade de ocorrência de movimentos de massas. (ROSS; MOROZ, 1997, p.31-33)

As unidades morfoesculturais Depressão do Médio Paraíba e Planície Fluvial do Rio Paraíba do Sul, são compreendidas pela Unidade Morfoestrutural Bacias Sedimentares Cenozóicas. (ROSS; MOROZ, 1997).

A morfoescultura Depressão do Médio Paraíba pertence a morfoestrutura Bacia Sedimentar de Taubaté [...]. Nesta unidade predominam formas de relevo denudacionais cujo modelado constitui-se basicamente por colinas de topos convexos [...]. As altimetrias predominantes são de 600 e $700 \mathrm{~m}$ e as vertentes apresentam declividade entre 5 e 20\%. (ROSS; MOROZ, 1997, p.50).

A geologia da região do Vale do Paraíba é caracterizada por duas grandes unidades: o Embasamento Cristalino, constituído por rochas metamórficas, migmatitos e granitóides relacionados ao Ciclo Brasiliano, iniciado no pré-Cambriano, e também outros ciclos mais antigos (FILIZOLA, 1993) e a Bacia Sedimentar de Taubaté.

\subsubsection{Como se forma uma Bacia Sedimentar}

Uma bacia sedimentar é composta por uma depressão topográfica, frequentemente, de origem tectônica, que posteriormente foi preenchida por rochas sedimentares e/ou vulcânicas, pode atingir espessuras que variam de centenas a alguns milhares de metros e totalizar uma área de centenas a poucos milhões de 
quilômetros quadrados. (SUGUIO, 2003). Quanto às formas, as bacias sedimentares podem ser classificadas em três tipos: fechada subcircular, aberta e fechada alongada (BOULIN, 1977 apud SUGUIO, 2003).

A bacia sedimentar do tipo intracratônica, mencionada anteriormente, é formada por movimentos lentos e verticais da crosta denominados epirogenéticos. (SANTOS, 2008). Segundo Suguio (2003), do ponto de vista estrutural, existe também a bacia pericratônica, outro tipo de bacia sedimentar formada em áreas alongadas de margens cratônicas. Esse autor também diferencia as bacias intracratônicas em "bacias de plataforma" e "bacias de afundamento" (rift valleys) e explica que as áreas mais estáveis em termos tectônicos são chamadas de crátons.

A respeito das bacias de afundamento, Suguio (2003) esclarece que são resultantes do rebaixamento de blocos de falha, constituindo vales estreitos e alongados que se encontram delimitados entre sistemas de falhas normais paralelos. A essas fossas tectônicas, originadas, em fases orogenéticas tardias e de dimensões relativamente pequenas, dá-se o nome de graben. Sobre esse abatimento de blocos, Santos (2008) lembra que a movimentação decorrente causa o abatimento de um bloco em relação a outro, resultando não só em baixos topográficos (fossas), mas em altos também, dispostos lateralmente e conhecidos por horsts.

\subsubsection{A Bacia Sedimentar de Taubaté}

A Bacia Sedimentar de Taubaté apresenta comprimento de $170 \mathrm{Km}$ e largura média de $25 \mathrm{Km}$, aproximadamente (CARVALHO; VIDAL; KIANG, 2011). De acordo com a classificação de bacias sedimentares brasileiras, ela pode ser identificada como de idade cenozoica e do tipo rifte. Seu formato está mais para o tipo "fechada alongada". (Vide figura 4).

De acordo com Ferreira (2007), há cerca de 70 a 65 milhões de anos atrás, na transição dos períodos geológicos Cretáceo e Terciário, movimentos tectônicos teriam provocado o surgimento de novas rachaduras nos terrenos do leste do Brasil e com elas, causaram um vale de afundamento (graben do Paraíba, neste caso, semigraben). Após milhares de anos, essa depressão teria sido lentamente preenchida pelas águas trazidas dos rios que desciam as serras e um grande lago teria se 
formado. O preenchimento deste por sedimentos é que originou a Bacia Sedimentar de Taubaté, situada entre dois horsts: a Serra da Mantiqueira e a Serra do Mar.

Figura 4 - Localização e formato "alongado" da Bacia de Taubaté.

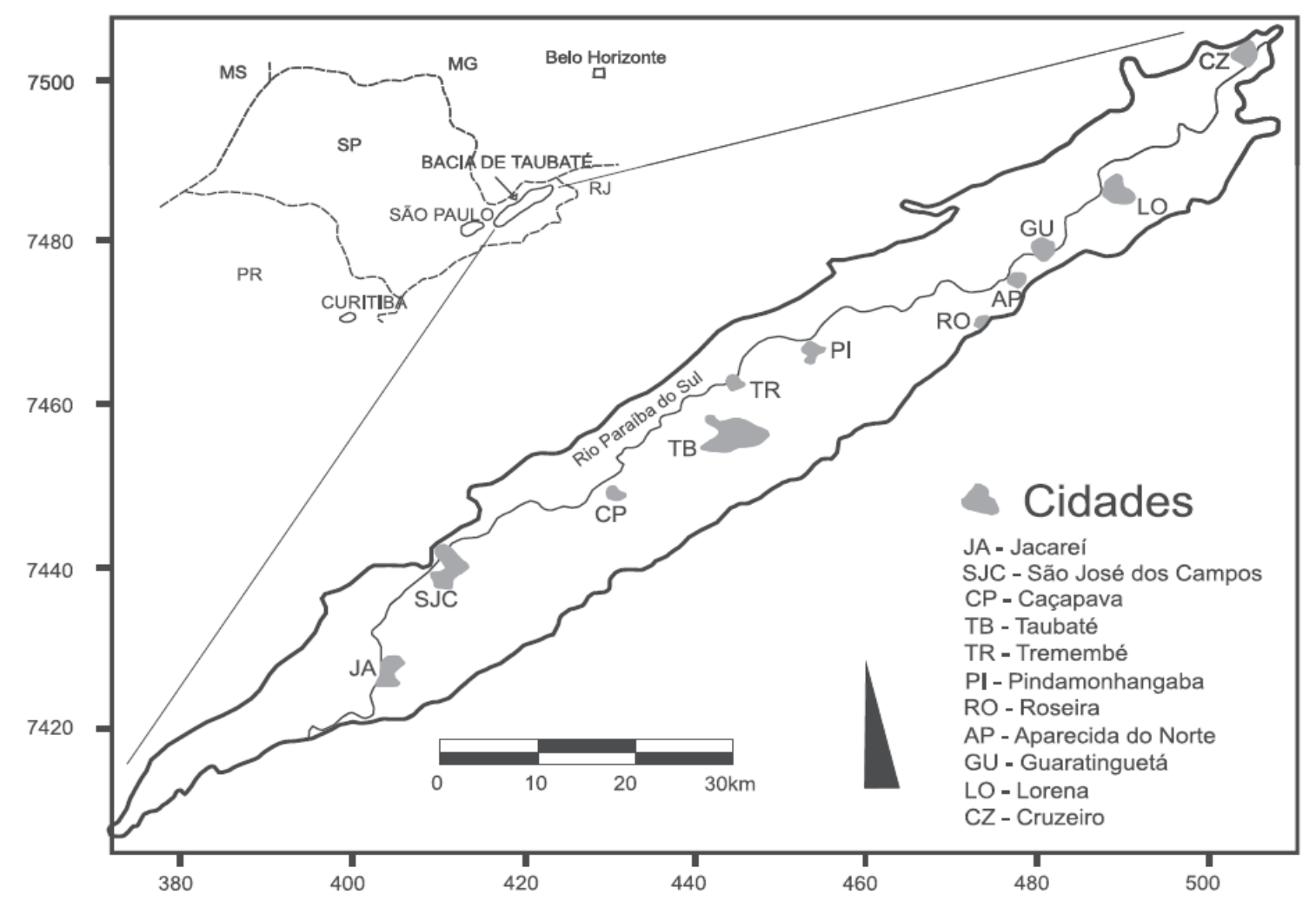

Fonte: Extraído de Carvalho, Vidal e Kiang (2011).

A origem tectônica desta bacia foi questionada por muito tempo, autores como Rego, acreditavam na sua origem como erosiva. Os primeiros que propuseram a hipótese de um graben foram Maull e Washburne, em 1930. (FILIZOLA, 1993). Segundo Riccomini (1989), tanto a Bacia de Taubaté, como as de Curitiba, São Paulo, Resende e de Volta Redonda, além de outras menores, estariam compreendidas dentro do Rift Continental do Sudeste Brasileiro (RCSB), de idade cenozoica. No entanto, a matriz na qual se assenta é formada por rochas ígneas e metamórficas do Cinturão de Dobramentos Ribeira e apresenta datações do Paleoproterozoico até o Neoproterozoico (HASUI; PONÇANO, 1978 apud CARVALHO; VIDAL; KIANG, 2011).

As camadas sedimentares da Bacia de Taubaté sofreram mudanças de nomenclatura, conforme a abordagem de diferentes autores. Segundo Ferreira (2007), os sedimentos mais finos que foram depositados no fundo do grande lago, que deu 
origem a bacia sedimentar (argilas) é que foram responsáveis pela formação das rochas sedimentares, com ocorrência de fósseis e à qual foi denominada Formação Tremembé. A camada acima desta formação, caracterizada por sedimentos argiloarenosos, de consistência mais grosseira e tons avermelhados e com rara ocorrência de fósseis denominou-se Formação Caçapava. Posteriormente, surgiu o Rio Paraíba do Sul, que escavou um novo vale sobre os antigos sedimentos, formando sua várzea atual.

Suguio (1969), baseado em estudos de Rego (1943) chamou essas camadas sedimentares de Formação Tremembé e Formação São Paulo, (vide figura 5) devido a correlações litológicas entre as bacias de Taubaté e de São Paulo, que apresentariam continuidade geográfica entre os sedimentos. (SUGUIO, 1969). O pacote sedimentar superior da bacia passou a ser chamado de Formação Caçapava em 1976, por Carneiro et al, os quais a distinguem da Formação São Paulo, alegando que ambas evoluíram de maneira independente, apesar de parcialmente sincrônicas. (FILIZOLA, 1993).

Figura 5 - Mapa Geológico da Bacia de Taubaté. Cor amarela: aluviões recentes; Cor vermelha: embasamento cristalino; Cor verde: sedimentos antigos. Hachurado: cidades.

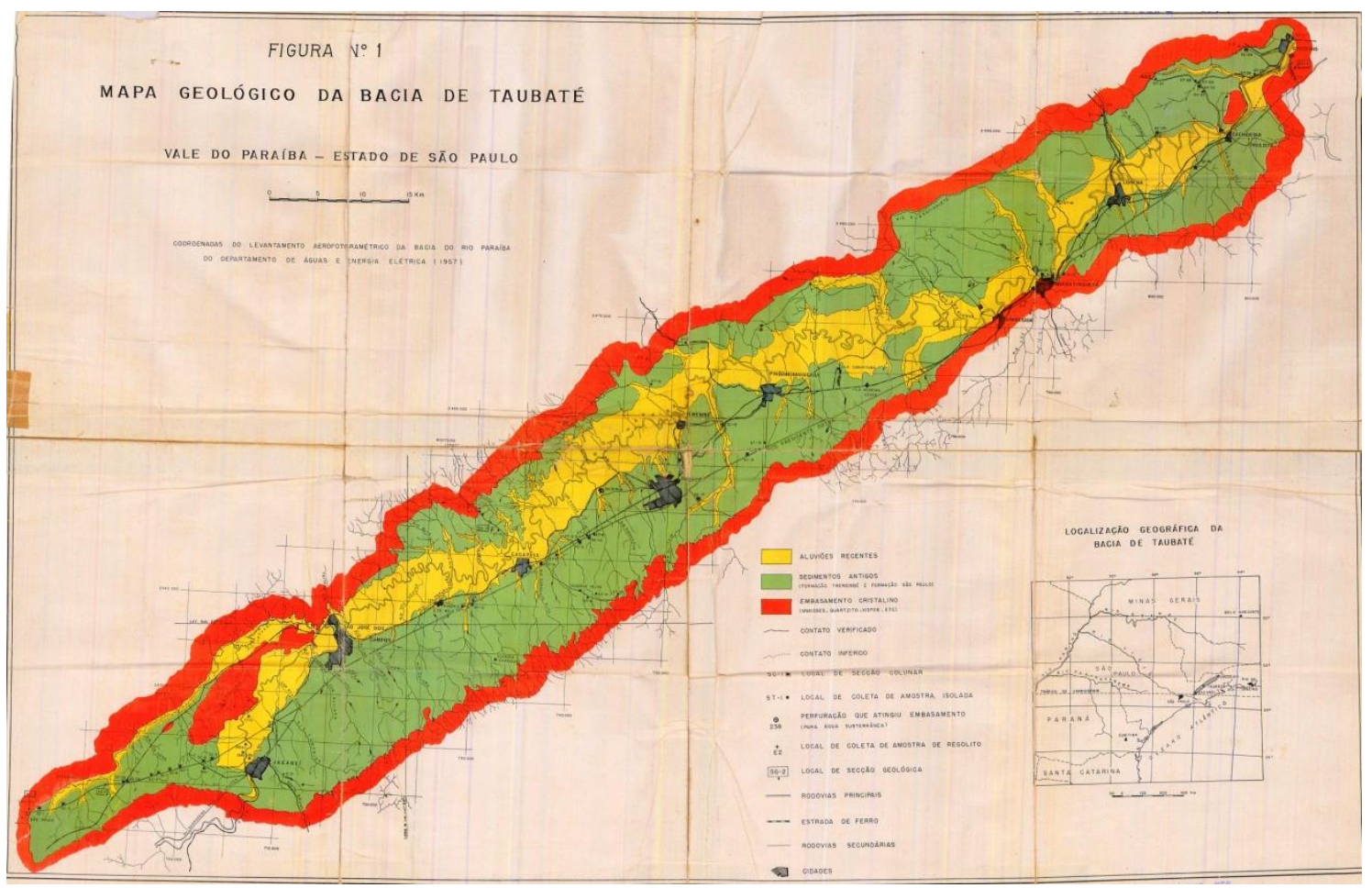

Fonte: Extraído de Suguio (1969). 
No final da década de 1980, o estudo de Riccomini reacende a discussão sobre as camadas sedimentares da Bacia de Taubaté. Este autor propõe uma nova nomenclatura para o conjunto de formações Resende, São Paulo e Tremembé, incluso o Basanito Casa de Pedra, denominado Grupo Taubaté.

\begin{abstract}
O preenchimento vulcano-sedimentar do rift (Grupo Taubaté), concomitante aos movimentos tectônicos dessa fase, compreende um sistema de leques aluviais associados à planície aluvial de rios entrelaçados (Formação Resende), basal e lateral na bacia, um sistema lacustre, mais propriamente caracterizável como playa-lake (Formação Tremembé), e um sistema meandrante (Formação São Paulo), este já numa fase de colmatação da depressão. Paralelamente, a região de Casa de Pedra, a sudeste de Volta Redonda assistiu a eclosão de derrames de Basanito (Basanito Casa de Pedra) associado ao sistema fanglomerático. (RICCOMINI, 1989, p.232).
\end{abstract}

A análise de Riccomini (1989), referente à nomenclatura das sequencias estratigráficas da bacia aqui estudada, refere-se à supressão dos termos "Formação Resende" e "Formação Caçapava". Consequentemente, o autor substituiu suas áreas de abrangência por nova denominação: Formação Pindamonhangaba. E esta é descrita como constituída por

[...] depósitos areno-argilosos da porção central da Bacia de Taubaté originados em sistema fluvial meandrante, que se encontram em discordância angular sobre os sedimentos do Grupo Taubaté e recobertos por colúvios quaternários. (MANCINI, 1995, p.18).

A Bacia Sedimentar de Taubaté também pode ser subdividida em três compartimentos: São José dos Campos, Taubaté e Aparecida. (FERNANDES; CHANG, 2001, 2003 apud CARVALHO; VIDAL; KIANG, 2011). Eles são delimitados por feições geológicas conhecidas como alto estrutural. Assim, entre o compartimento São José dos Campos e Taubaté, temos o Alto Estrutural de Caçapava e entre Taubaté e Aparecida, o Alto Estrutural de Pindamonhangaba. (FERNANDES, 1993 apud CARVALHO; VIDAL, KIANG, 2011).

O alongamento desta bacia é determinado por dois conjuntos de sistemas de falhas, relativamente paralelos entre si, que são mais antigas. E transversais a elas, foram identificadas mais quatro falhas, pelo menos. Durante seu preenchimento, deve ter perdurado um clima semi-árido, fato comprovado pela ocorrência de feldspato e calcrete nas areias, além da natureza das argilas (esverdeadas), evidenciando a presença de montmorillonita, que é incompatível com o clima atual. (SUGUIO, 1969). 
O embasamento cristalino da bacia supracitada compõe-se por rochas metamórficas do Complexo Brasileiro (de idade pré-cambriana), formadas por gnaisses (do tipo fitado: quartzo, feldspato e biotita) e micaxistos como rochas predominantes e que somam $65 \%$ do perímetro da bacia. Também há a ocorrência, pouco significativa, de mármores (em Cruzeiro, Lavrinhas, Santa Izabel, Barreiras e Taubaté) e de quartzitos, além da presença de diques de diabásio que atravessam os gnaisses, no sentido paralelo às suas direções. (SUGUIO, 1969).

Além das unidades estratigráficas já mencionadas, nesta região constam o Complexo Embu, "constituído principalmente de migmatitos com composição variável, [...] xistos peraluminosos de médio grau metamórfico, e gnaisses." (SANTORO; ENS; NAGATA, 1991, p.483), e o Complexo Paraíba do Sul, formado por gnaisses e migmatitos blastomiloníticos, biotita gnaisses por vezes com granada, com porfiroclastos de k-feldspatos milimétricos a subcentímetros, intercalações de rochas cálcio-silicáticas, sillimanita-granada xistos e anibolitos. (IPT, 1991).

\title{
3.4 A COBERTURA PEDOLÓGICA
}

Segundo o Manual Técnico de Pedologia, a melhor definição de solo para a realização de um levantamento pedológico, é a seguinte,

\begin{abstract}
Solo é a coletividade de indivíduos naturais, na superfície da terra, eventualmente modificado ou mesmo construído pelo homem, contendo matéria orgânica viva e servindo ou sendo capaz de servir à sustentação de plantas ao ar livre. Em sua parte superior, limita-se com o ar atmosférico ou águas rasas. Lateralmente, limita-se gradualmente com rocha consolidada ou parcialmente desintegrada, água profunda ou gelo. O limite inferior é talvez 0 mais difícil de definir. Mas, o que é reconhecido como solo deve excluir o material que mostre pouco efeito das interações de clima, organismos, material originário e relevo, através do tempo. (IBGE, 2015, p.7).
\end{abstract}

Os solos predominantes na área de estudos são: Latossolos Vermelhos (LV), Latossolos Vermelhos-Amarelos (LVA) e Gleissolos Melânicos (GM). A respeito do solo tipo GM, baseada no mapa pedológico do IAC - Instituto Agronômico (1999), vide figura 6, Moura (2006) afirma que

[...] as áreas da Bacia Sedimentar de Taubaté desde Jacareí até Cachoeira Paulista acompanhando o Vale recente do Paraíba do Sul foram classificadas como de Gleissolos (Húmicos e Hidromórficos Cinzentos) devido ao fato dessa área estar associada a áreas de aluviões (depósitos de calhas e 
terraços) com relevo de plano até suavemente ondulada, a níveis topográficos entre 400 e $500 \mathrm{~m}$. Possui uma drenagem insuficiente ou imperfeita acentuada nos períodos de chuva com o constante encharcamento das áreas de várzea. (MOURA, 2006, p.7).

Sobre os Latossolos Vermelhos e os Latossolos Vermelhos-Amarelos, a mesma utiliza-se da seguinte descrição

Estes solos são encontrados no Paleovale do Paraíba do Sul nas áreas mais baixas das vertentes das Serras da Mantiqueira e do Mar compreendendo boa parte dos municípios localizados no Vale do Paraíba em regiões com relevos que vão de suavemente ondulado a ondulado em altitudes que variam de 500 a $1000 \mathrm{~m}$ o que favorece a infiltração da água nesses solos e sua evolução. São derivados preferencialmente de rochas como granitos e gnaisses e possuem uma transição entre os horizontes gradual ou difusa 0 que os torna menos erodíveis a ação erosiva das chuvas (MOURA, 2006, p.6).

Figura 6 - Solos do estado de São Paulo.

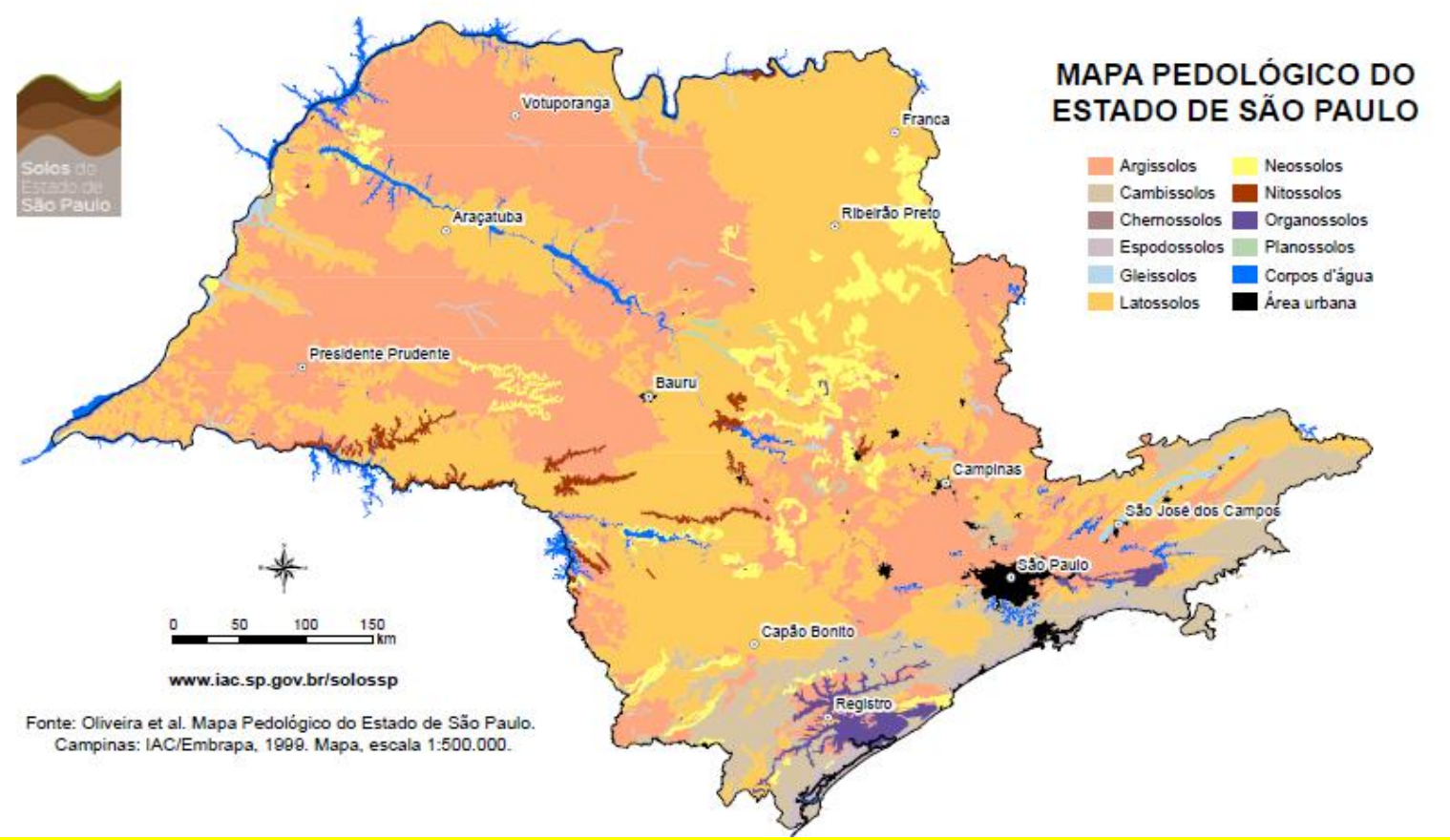

Fonte: IAC, (1999).

Dois processos que podem afetar diretamente o solo e influenciar no modelado do terreno são os movimentos de massa e o coluvionamento. 


\title{
3.4.1 Movimentos de massa
}

Segundo o dicionário de Geologia Sedimentar e áreas afins, de autoria de Suguio (1998, p.351), movimento de massa é sinônimo de fluxo gravitacional, e pode ser definido como

\begin{abstract}
Mecanismo de transporte e sedimentação ou depósito formado por transporte de sedimentos paralelamente ao substrato, por efeito da gravidade, onde as partículas são mantidas em dispersão. Existem quatro tipos principais de fluxo gravitacional, que são os seguintes: (a) corrente de turbidez [...] onde os grãos são sustentados pela turbulência: (b) fluxo granular [...] onde os grãos são sustentados pela interação direta das partículas; (c) fluxo fluidificado [...], onde os grãos são sustentados pelo escape ascendente de fluido intergranular e (d) fluxo de detritos [...] onde os grãos são sustentados pela resistência da matriz. [...].
\end{abstract}

Os movimentos de massa são influenciados pelas condições da estrutura geológica, tipo de materiais, orientação e forma da vertente, declividade, área de contribuição e intensidade e distribuição das precipitações. (FLORENZANO, 2008).

\subsubsection{Coluvionamento}

Colúvio pode ser definido como

Designação genérica aplicada a depósitos incoerentes, de aspecto terroso, localizados em vertentes e sopés de relevo mais ou menos acentuados. Tálus e detritos de escarpas, transportados principalmente pela ação da gravidade, podem ser incluídos nesta categoria. (SUGUIO, 1998, p. 161).

O depósito coluvial constitui-se de um registro da evolução geomorfológica e pode ser caracterizado como constituídos de sedimentos areno-argilosos, apresentando aspecto maciço, além de conter fragmentos rochosos de tamanhos variados e mais ou menos intemperizados. Pode ser o resultado de um descolamento de curta distância por rastejo (do solo ou da rocha). A maior espessura de alguns depósitos é característica de depressões de paleorrelevos ou de áreas onde ocorreram fenômenos de solifluxão de forma intensa. (SUGUIO, 2003).

Acredita-se que as feições do relevo investigadas nesse estudo podem ter sofrido a ação dos dois fenômenos acima mencionados, o que influenciaria na 
deposição e movimentação dos possíveis materiais arqueológicos enterrados nesses locais.

\subsection{A REDE DE DRENAGEM}

O sistema de bacias hidrográficas do estado de São Paulo possui 22 Unidades Hidrográficas de Gerenciamento dos Recursos Hídricos - UGRHI. Pindamonhangaba pertence a UGRHI - Paraíba do Sul. Vide figura 7.

O rio Paraíba do Sul é o principal corpo hídrico da região do Vale do Paraíba e também a divisa natural de dois estados, Rio de Janeiro e Minas Gerais. Neste, suas águas percorrem cerca de 20.700 km, no estado do Rio de Janeiro, 20.900 km e em São Paulo, 13.900 Km, somando 55.500 Km. (ANA, 2017).

O Rio Paraíba do Sul nasce no estado de São Paulo, a 1.800 metros de altitude, na confluência dos rios Paraitinga e Paraibuna, na Serra da Bocaina, e deságua no Oceano Atlântico, em Atafona (RJ). Como principais tributários, são apontados: rios Piraí, Piabanha, Dois Rios, Uma e Bananal, pela margem direito e, rios Jaguari, Paraibuna, Pirapetinga, Pomba e Muriaé e pela margem esquerda. AGEVAP, 2013). 
Figura 7 - Unidade de Gerenciamento de Recursos Hídricos do Estado de São Paulo - UGRHI 2

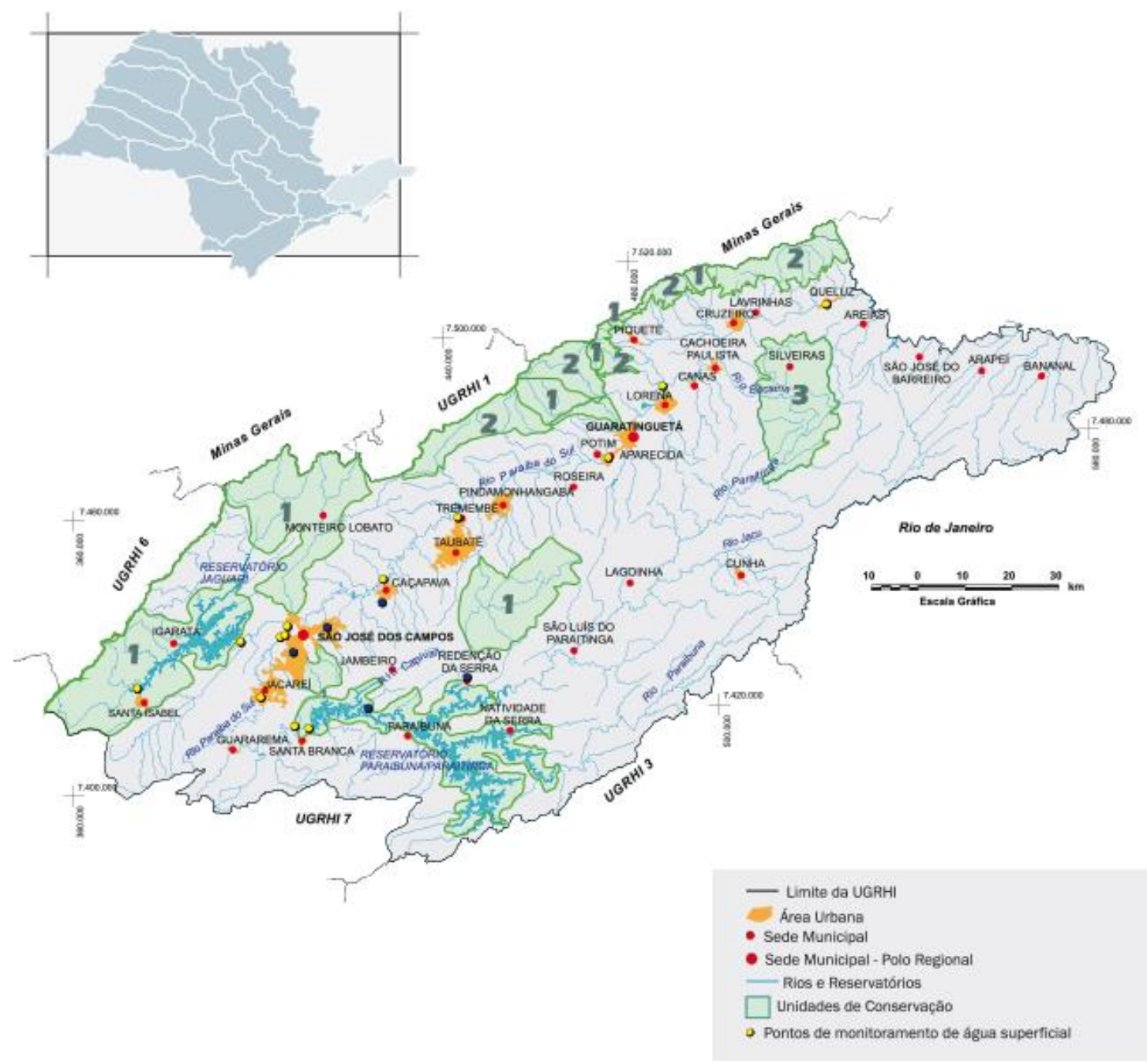

Fonte: SÃO PAULO (2017).

A rede de drenagem em Pindamonhangaba é formada pelos rios Paraíba, Una, Piracuama e Tapanhão, pelos Ribeirões dos Surdos, do Cortume e do Ipiranga, entre outros cursos d'água de menor porte. (PINDAMONHANGABA, 2016).

\subsubsection{As depressões circulares}

Segundo Xavier e Coelho Neto (2008, p.61), as "depressões fechadas são proto-vales que apresentam ausência de um canal de saída de fluxos d'água superficiais." Processos de denudação geoquímica também são apontados como fatores de origem das depressões, que podem apresentar-se pequenas, como 
cabeceiras de drenagem ou bastante desenvolvidas e desconectadas de qualquer canal. No Vale do Paraíba, elas se apresentam com mais frequência na vertente da Serra da Mantiqueira. (XAVIER; COELHO NETO, 2008).

Por serem muito comuns na paisagem, as depressões circulares do Vale do Paraíba já eram mencionadas em trabalhos de Ab'saber e Bernardes, em 1958 (FILIZOLA, 1993). Coltrinari (1975) e Xavier e Coelho Neto (2008), também as tiveram como objeto de estudos, preocupando-se com questões como a sua gênese, por exemplo. Nessa pesquisa, porém, elas são entendidas como áreas de interesse arqueológico, devido a sua provável condição de provedora de recursos aos grupos humanos em tempos recuados.

Segundo Filizola (1993), que estudou as depressões circulares interfluviais nos municípios de São José dos Campos e Caçapava, elas apresentam-se: pouco profundas, completamente fechadas ou com um eixo de escoamento, frequentemente com água ao longo de todo o ano, e localizadas tanto nos interflúvios, como nos terraços mais altos. A análise de amostras de turfa de uma dessas depressões (Depressão Sony, em São José dos Campos), que permanece submersa permanentemente, revelou formação entre 17.000 e 12.000 anos BP.

Para a autora, esta "paleoturfa" é um marco cronológico e permite avaliar a velocidade de afundamento das depressões fechadas. Para o contexto de uma investigação arqueológica, com foco no estudo de paleoambientes, esse dado reforça a ideia de que o conhecimento da geomorfologia é essencial no co-relacionamento de dados ligados a formação do registro arqueológico. Nesse viés, reafirma-se a importância da Geoarqueologia como ferramenta para uma melhor compreensão do registro arqueológico e remete-se, a Renfrew (1976) apud Goldberg (2008, p.33) para quem "[...] every archaeological problem starts as a problem in geoarqueology." O que em tradução literal seria "cada problema arqueológico começa como um problema geoarqueológico."

A presença de turfa no Vale do Paraíba não se limita ao interior das depressões, tendo sido identificada também às margens do Rio Paraíba do Sul, em depósitos, distribuídos ao longo de uma vasta área de aproximadamente cinquenta hectares, entre os municípios de Jacareí e Roseira, no estado de São Paulo. Os estudos que indicaram essas áreas de abrangência de turfeiras, realizados no Brasil, no final da década de 1970 e início da de 1980 tiveram por objetivo inicial verificar o 
potencial energético das mesmas, e posteriormente, procurou-se importar tecnologia para a extração e conversão da turfa em fontes de energia (CPRM, 1980 apud OSTAFIUC, 1986).

Por motivos diferentes destes, Garcia et al (2004) se incluem no grupo de pesquisadores interessados nos depósitos de turfa desta região. Seus dados indicam que os pólens encontrados em meio aos depósitos contêm remanescentes de paleovegetação, sendo considerados, portanto, indicadores paleoclimáticos. A idade das amostras de turfa, (coletadas no município de Jacareí), varia de ca. 1.950 a 9.700 anos AP e aponta para a existência de períodos climáticos distintos neste intervalo (úmido e frio de 9.720 a ca. 8.240 anos $\mathrm{AP}$, úmido e quente de ca. 8.240 a 3.500 anos AP e mais frio e úmido que hoje, de 3.500 a 1.950 anos AP).

A ocorrência de sítios arqueológicos próximos a depressões circulares e seus arredores, que corrobora com a nossa hipótese de que tais locais apresentam alto potencial arqueológico, já foi confirmada em outras regiões do país e mesmo no estado de São Paulo. Embora o contexto ambiental seja diferente do encontrado no Vale do Paraíba, os exemplos que serão dados, a seguir, justificam-se pela função que essas lagoas tiveram para os povos pretéritos, como fonte de recursos.

A Lagoa do Sumidouro, localizada no município de Pedro Leopoldo, no estado de Minas Gerais e que fica na Região de Lagoa Santa, área amplamente conhecida por abrigar sítios arqueológicos Paleoíndios, é uma das áreas onde foram encontrados e escavados três sítios a céu aberto. De acordo com Araujo e Neves (2012), os estudos arqueológicos realizados naquela região, entre os anos de 2000 e 2009, por meio do Projeto "Origens e Microevolução do Homem na América", revelaram a existência de dois sítios arqueológicos que se destacam por suas idades recuadas: o Sítio Sumidouro, localizado na margem sudeste da lagoa, que apresentou idade radiocarbônica de $8.310 \pm 40$ AP (9.240 a 9.450 cal AP) e idade de luminescência entre 10.100 e 12.500 anos AP, e o Sítio Coqueirinho, situado na margem sul da lagoa e cuja idade radiocarbônica obtida foi de 10.460 AP (12.090 a 12.690 cal AP).

Outro exemplo de sítio arqueológico, localizado a céu aberto e próximo a uma grande depressão, é o sítio lítico Lagoa do Camargo, situado na vertente oeste da Lagoa do Camargo, no município de Ipeúna, estado de São Paulo, cuja datação é de mais de 10.000 anos cal AP. Além de material lítico (peças de silexito e de 
quartzito), encontrado em um talhão, também foram identificados materiais arqueológicos recentes (porcelana, tijolos e telhas) no local (ARAUJO, 2012).

Supondo-se que as lagoas maiores, identificadas em Pindamonhangaba, pela carta topográfica do município, na escala de 1:50.000 (destaque em vermelho, figura 8), também seriam áreas de atração de grupos pré-históricos na região do Vale do Paraíba, as mesmas foram selecionadas para análise quanto a sua morfologia, tamanho e função dentro de um contexto ambiental que pode ter sido arqueológico também.

Figura 8 - Recorte da Carta Topográfica de Pindamonhangaba destacando uma área de interesse.

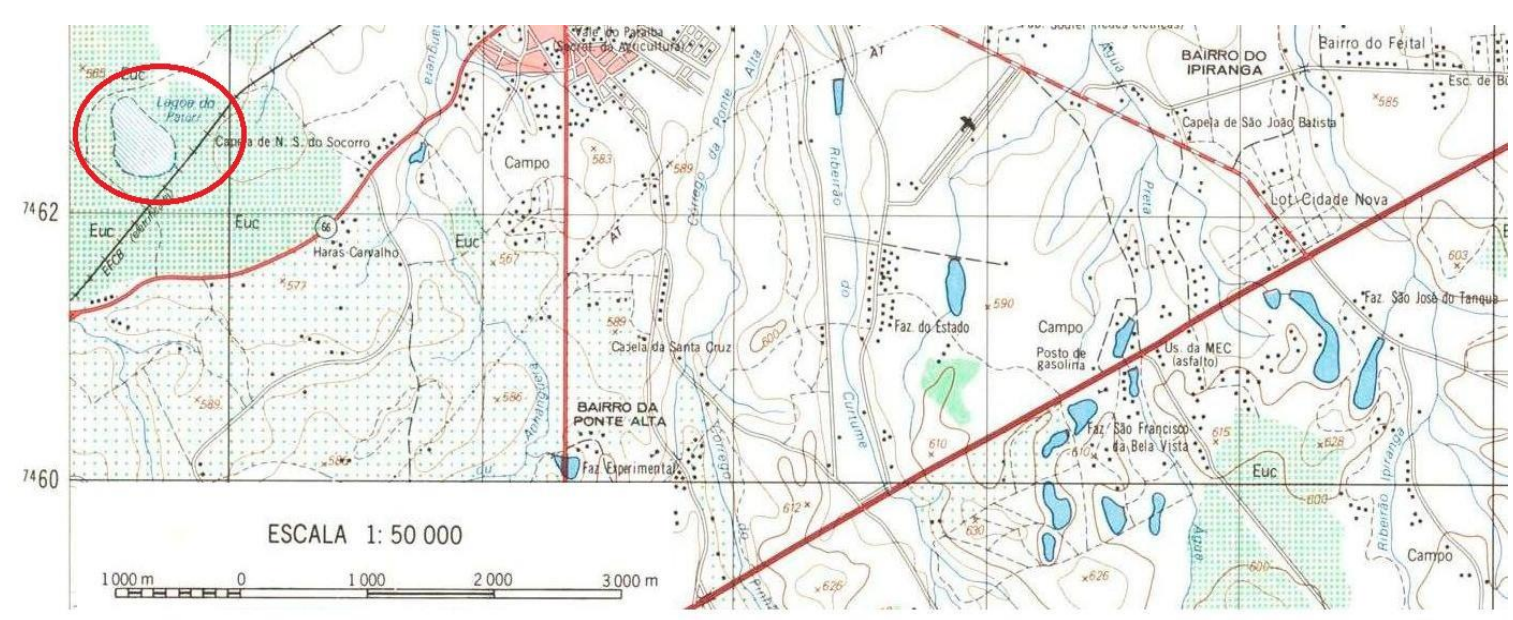

Fonte: IBGE (1988). Org. LEAL (2014).

A depressão destacada na figura 8 é a Lagoa do Paturi. Atualmente, essa lagoa está inserida em um contexto urbano, densamente povoado (vide figura 9), porém, sua área e arredores consta da ZIA - Zona de Interesse Ambiental do município. 
Figura 9 - Imagem da Lagoa do Paturi em Pindamonhangaba

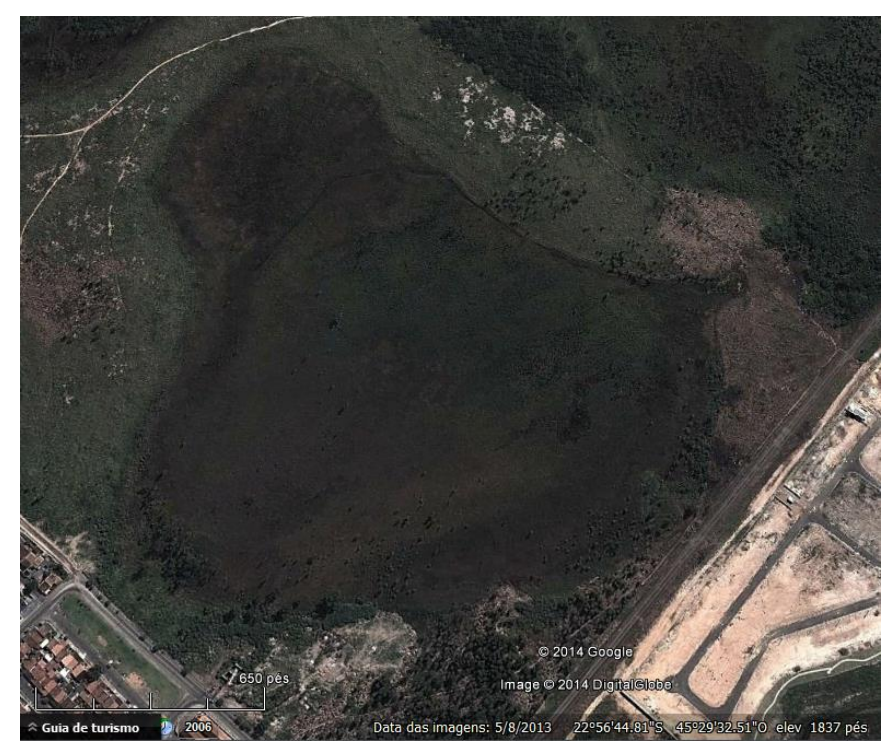

Fonte: Google Earth (2014).

\subsubsection{Os terraços fluviais}

Outro ponto de interesse deste estudo refere-se às características geomorfológicas dos terraços fluviais de rios de grande porte e áreas adjacentes. Sabe-se que, no caso do rio Paraíba do Sul, os depósitos alúvio-fluviais são recentes (ROSS; MOROZ, 1997), portanto não se espera que sítios Paleoíndios sejam encontrados neles. Porém, em áreas adjacentes, como por exemplo, nos terraços quaternários, que se localizam entre três e oito metros de atitude acima do nível da planície de inundação (COLTRINARI, 1975) ou mesmo em áreas próximas a meandros abandonados, quando se apresentam em altitudes diferentes do rio principal, o potencial arqueológico é maior.

O termo meandro designa "o tipo de canal fluvial em que os rios descrevem curvas sinuosas, largas, harmoniosas e semelhantes entre si, através de um trabalho contínuo de escavação na margem côncava [...] e de deposição na margem convexa [...]" (CHRISTOFOLETTI, 1981, p.85). E segundo o mesmo autor, "meandro abandonado" é aquele que não possui mais ligação com curso de água atual, de forma direta.

O caráter meândrico do rio Paraíba do Sul é descrito a seguir

O rio Paraíba do Sul se constitui num sistema fluvial meandrante cujo canal descreve vários caminhos ao longo de um cinturão meândrico e, às vezes, até o abandona, por avulsão, e escapa pela várzea de inundação onde irá 
construir um outro cinturão. Alguns elementos geomorfológicos desse tipo de sistema, tais como barras de pontal, diques marginais e canais abandonados, constituíram-se em referências básicas, ou guias para se proceder à reconstituição dos vários caminhos do canal fluvial meandrante do rio Paraíba do Sul em tempos pré-atuais (SANTIAGO; TEIXEIRA; TRONCHINI, 1999, p. 101).

O interesse por pesquisas arqueológicas em planícies aluviais (floodplain) tem aumentado nos últimos anos (BROWN, 2001). Como exemplo do estudo da relação entre sítios arqueológicos e planícies aluviais, a partir de uma abordagem geoarqueológica, remete-se, mais uma vez ao trabalho de Kashimoto, Sallun e Suguio (2008). De acordo com os autores, a interpretação arqueológica do Alto Paraná só foi possível por meio de "intensivas pesquisas de campo e constituição de um amplo banco de dados que inclui características da cultura material, datações radiométricas, análises geomorfológicas e sedimentológicas." (p.128).

Oportunidades e problemas da utilização de planícies aluviais, por grupos humanos pretéritos, se constituem conforme o tipo de planície aluvial e o sistema de canal fluvial ocupados. As evidencias de ocupação dessas áreas podem ser maiores ou menores, conforme o padrão de migração do canal fluvial (nível de sedimentação), que interfere na distribuição de sítios enterrados e localizados em planícies aluviais. Nessas condições, em sítios enterrados que não são identificados pelos métodos tradicionais como caminhamento e fotografia aérea (mas útil para terraços adjacentes acima do nível de inundação), outros métodos podem ser empregadas. (BROWN, 2001).

A viabilidade do uso de algumas dessas técnicas, mencionadas por Brown (2001, p.41) será discutida ao longo deste trabalho. São elas: a inspeção de exposições naturais, margens de rios e escavações artificiais incluindo diques, drenos e cascalheiras extraindo cascalho sub-aluvial; a identificação de locais prováveis de evidências indiretas, canais especialmente velhos e ilhas de várzea, identificados a partir de fotografias aéreas e mapas antigos; a utilização de métodos geofísicos que têm a capacidade de penetrar em espessuras significativas de aluvião; furos de sondagem por trado de mão, especialmente nas bordas das planícies aluviais e análises morfométricas de alguns parâmetros de várzea, incluindo largura, profundidade e área transversal sedimentar. 


\section{A DISTRIBUIÇÃO DO REGISTRO ARQUEOLÓGICO NA ÁREA DE ESTUDO}

Para ajudar a identificar as áreas preferenciais de ocupação humana pelos grupos pré-coloniais que ocuparam a área de abrangência desta pesquisa, fez-se o levantamento dos sítios e das ocorrências isoladas de material arqueológico do Vale do Paraíba Paulista. Porém, antes, para melhor compreender a lógica de ocupação dessa porção do território paulista, considerou-se relevante uma breve discussão acerca dos fluxos migratórios de grupos humanos que adentraram no país e, de modo geral, no continente americano.

Talvez porque perguntas como "de onde viemos", "para onde vamos" ou "porque estamos aqui" sejam inerentes a natureza do ser humano, as migrações humanas constituem tema de interesse de diversas áreas do conhecimento (Biologia, História, Geografia, Arqueologia, Antropologia, etc.). Em uma perspectiva arqueológica, a questão dos deslocamentos de grupos humanos pode ser estudada por meio da identificação de padrões de distribuição dos vestígios arqueológicos na paisagem. Segundo Araujo (2001, p.96), o registro arqueológico pode ser definido como "uma distribuição de artefatos e feições arqueológicas mais ou menos contínua sobre o terreno, com características de densidade altamente variáveis."

\subsection{SÍTIOS PALEOÍNDIOS E A OCUPAÇÃO DO CONTINENTE AMERICANO}

Os grupos humanos os quais esta pesquisa abrange são aqueles que já habitavam o território do Vale do Paraíba Paulista antes da colonização portuguesa, inclusive os grupos Paleoíndios. Segundo Araujo (2015), o termo Paleoíndio costuma ser empregado no Brasil para ser referir a populações que existiram entre $12.900 \mathrm{e}$ 8.300 anos cal AP.

A antiguidade do povoamento da América tem sido debatida por arqueólogos e demais pesquisadores do tema, os quais seguem duas linhas de pensamento distintas: uma que admite a existência de grupos humanos na América apenas por volta de 12 mil anos AP e outra que acredita em uma ocupação anterior a esta data (LIMA, 2006).

A hipótese mais aceita para a origem do homem americano aponta a migração de grupos humanos que se dispersaram pela Ásia por meio da transposição 
do Estreito de Bering. Esta "passagem" trata-se, na verdade, de uma região abrangida por uma extensa planície emersa, pelo nordeste da Sibéria (do lado asiático) e por porções do Alasca e do Yukon (do lado americano) e que foi denominada Beríngia. A partir do Alasca, três rotas de dispersão pelo continente americano são cogitadas:

[...] a primeira, pelo litoral setentrional, alcançando o Rio Mackenzie e daí seguindo em direção sul. A segunda, pelo litoral meridional de Beríngia, beirando a costa sudeste do Alasca, e descendo pela costa do Pacífico. E a terceira, pela região central do Alasca, através dos vales, tomando o rumo do sul (LIMA, 2006, p.83).

Este modelo de ocupação da América (das três migrações) é apoiado, principalmente, pela detecção de sítios Paleoíndios (datados entre 11.500 e 11.000 anos) ao longo de todo o continente e que são caracterizados pela ocorrência de pontas de projétil bifaciais do tipo "Clóvis". O grupo de caçadores Clóvis seria, de acordo com a literatura, especializado na caça de grandes mamíferos e capaz de se adaptar a ambientes diversos. Durante muito tempo, os caçadores Clóvis foram considerados os primeiros habitantes da América. Porém, a posterior detecção de sítios com idades mais recuadas colocou este "paradigma de ocupação" em cheque. Como exemplos de sítios mais antigos, Lima (2006) destaca: Meadowcroft, na América do Norte (com datações de carvão de até 31.400 anos), Monte Verde, no Chile, com dois componentes - Monte Verde II (12.500 a 13.000 anos) e Monte Verde I (33 mil anos) - e Toca do Boqueirão de Pedra Furada, no Brasil (com sequencias estratigráficas de 48.000 até 6.000 anos AP). O Sítio do Meio (24.200 cal AP) e Santa Elina (23.000 AP) também são lembrados por Araujo (2013) e a ocorrência de todos eles tem reforçado a hipótese de uma ocupação "pré-clovis".

Às evidências realçadas por estes sítios somam-se as contribuições de Neves e Pucciarelli que, em 1990, revelaram a existência de uma população não mongoloide na América (LIMA, 2006). De acordo com Neves (2006), Luzia (um esqueleto encontrado durante uma missão franco-brasileira no sítio Lapa Vermelha IV, região de Lagoa Santa-MG, na década de 1970) pertenceria a representante de uma população africana, a qual teria migrado para o continente americano antes dos representantes da cultura Clóvis (oriundos da Ásia).

A constatação de Neves vai além, e o mesmo propõe um novo modelo de migração para a América: 
[...] Neves vem defendendo o modelo substituto das quatro migrações, que incorpora essa leva não-mongolóide, a qual teria penetrado em território americano pouco antes das populações mongoloides. Para Neves, uma população originária da África teria alcançado o sudeste asiático, parte dela teria se deslocado para a Austrália, correspondendo aos aborígenes australianos, e outra leva teria subido em direção ao nordeste e atravessado Beríngia, constituindo a primeira leva de povoamento da América (LIMA, 2006, p.95-96).

Ademais, outra linha de raciocínio, que vem ganhando maior notoriedade a respeito das teorias migratórias, é a que ressalta o povoamento da América por povos marítimos, que teriam navegado pela borda do Pacífico. Ao longo de toda a faixa costeira americana têm sido registrados sítios com datas antigas - 9.000 e 11.200 anos AP - com evidências do controle destes grupos sobre ambientes costeiros e de sua familiaridade com ambientes litorâneos (LIMA, 2006). Esse fato, somado a outros, apontados por diversos autores, intensifica o questionamento do modelo Clovis First (ARAUJO, 2013; LIMA 2006; NEVES, 2006) e contribui para o estabelecimento de um novo modelo de migrações para a América.

Especificamente na América do Sul, além dos já mencionados, outros sítios Paleoíndios se destacam pela idade e também por se diferenciarem do modelo de paleoíndio norte-americano (caçadores especializados, detentores de alto potencial de mobilidade). Quebrada Jaguay, na costa sul do Peru (11.200 e 9 mil anos AP), Fell, Palli Aike, Cueva Del Medio e Lago Sofia, no Sul do Chile (12.390 e 11.570 anos AP) e Querero, no norte do mesmo país (11.600 e 10.900 anos AP) são alguns exemplos mencionados por LIMA (2006). Aproximadamente sessenta sítios (distribuídos por Argentina, Brasil, Chile, Colômbia, Equador, Peru e Venezuela) considerados mais antigos que 11.500 anos AP são apontados por Araujo (2013).

Uma síntese de ocorrência de sítios arqueológicos no país, no período entre 13.000 e 8.000 anos $C^{14}$ AP e suas respectivas datações é feita nos estudos de Bueno, Dias e Steele (2013), no qual os autores discutem a dispersão dos grupos humanos pelo território brasileiro em 90 sítios e 174 eventos de ocupação. Embora distribuídos de norte a sul do país, as áreas de maior concentração de sítios Paleoíndios, em território brasileiro, são os estados de Minas Gerais, Goiás e Rio Grande do Sul. (ARAUJO, 2013).

No estado de São Paulo, área de interesse deste estudo, inicialmente, constava somente o sítio Alice Boer, com idade entre 8.000 e 8.500 anos AP (ARAUJO, 2012). Porém, investigações arqueológicas posteriores revelaram a 
existência de outros dois sítios Paleoíndios no estado: o sítio Carcará, em São José dos Campos e o Sítio Lagoa do Camargo, em Ipeúna e datado em 10.500 anos cal AP (ARAUJO, 2012). O sítio Carcará, bem como o Sítio Pica-Pau Amarelo, foram encontrados durante estudos arqueológicos para fins de licenciamento ambiental ( $A$ LASCA, 2011). O primeiro foi datado entre 9.740 a 10.180 anos cal AP (A LASCA, 2012), porém, o segundo, apesar de também ter sido relacionado a grupos caçadorescoletores (ASSUNÇÃO; BELÉM; JULIANI, 2011), não tem dados de datação.

$\mathrm{Na}$ Bacia do Ribeira do Iguape, datações por $\mathrm{C}^{14}$ em estruturas semelhantes a sambaquis de materiais diversos tais como conchas, ossos humanos e carvões, revelaram idades que variam de 10.000 a 1.000 anos cal AP (FIGUTI; PLENS; DEBLASI, 2013). Recentemente, estudos no Sítio Bastos, localizado na região central do estado de São Paulo, revelaram datações entre 7.600 e 12.600 anos cal AP. (ARAUJO; CORREA, 2016). E em São Manuel, no mesmo estado, está sendo escavado o Sítio Caetetuba, cujas datações calibradas estão entre 9.245 e 11.080 AP. (TRONCOSO; CORRÊA; ZANETTINI, 2016).

\subsection{O POVOAMENTO DO VALE DO PARAÍBA PAULISTA}

A importância do rio Paraíba associa-se ao povoamento e fundação da maior parte dos municípios dessa região. A zona do Vale do Paraíba foi adentrada por colonizadores portugueses e, mais tarde, pelos jesuítas, entre os anos de 1560 e 1620, período durante o qual a região teria sido habitada por diversos grupos indígenas, das tribos Maramomis, Puris, Tamoios, entre outras (ABREU, 1977).

Segundo Pasin (1988), para quem a região do Vale do Paraíba teria sido uma das pioneiras do interior do país a ser explorada pelos colonizadores portugueses, com o intuito de abrir caminho para se chegar ao ouro e demais metais preciosos das Minas Gerais, o povoamento das terras do sertão do rio Paraíba foi iniciado em 1628, a partir da instalação do pioneiro Jacques Félix e de seus descendentes.

A ocupação e utilização das várzeas do rio Paraíba teve início em 1850, com a implantação de colônias agrícolas pelo governo provincial, em Lorena, Pindamonhangaba, Taubaté e Paraibuna. [...] Estas colônias resultaram da necessidade de se ocupar as várzeas do Paraíba e as áreas livres dos municípios, tendo em vista o domínio absoluto do café e as crises periódicas de abastecimento de cereais e legumes. (PASIN, 1988, p.46). 
Posteriormente, partes das margens do rio Paraíba do Sul foram utilizadas para o cultivo do arroz, que foi a base da produção agrícola (durantes as décadas de 1970 a 1990) de importantes municípios do Vale, como São José dos Campos, Caçapava, Pindamonhangaba, Roseira, Guaratinguetá e Lorena (LEAL, 2008).

Atualmente, outra atividade econômica que se percebe em vários trechos do rio Paraíba do Sul é a frequente exploração de cavas de areia. A condição morfológica e a gênese da bacia hidrográfica do rio Paraíba do Sul, caracterizada por construções arenosas em seu canal fluvial, são apontados como fatores determinantes de seu potencial de areia. (SANTOS NETO, 2004; COSTA, 2004). A inclusão do Vale do Paraíba como região fornecedora de areia ocorreu no município de Jacareí, no ano de 1949 e deveu-se a sua proximidade com a capital do estado, São Paulo (SANTOS NETO, 2004). Depois, a atividade areeira avançou para São José dos Campos e Caçapava e, na década de 1980, expandiu-se para Taubaté, Tremembé e Pindamonhangaba (SMA, 1997 apud COSTA, 2004).

Este estudo, porém, interessa-se, principalmente, pelo papel que o rio Paraíba do Sul e outros corpos hídricos possam ter desempenhado em tempos remotos, como fonte de recursos para grupos humanos ceramistas e de caçadorescoletores, que possam ter habitado a região do Vale do Paraíba do Sul, muito antes dos colonizadores chegarem. De acordo com Gaspar, Barbosa e Cordeiro (2007), não há muitos estudos arqueológicos sistemáticos no Vale do Paraíba, o que acarreta grandes lacunas cronológicas e culturais. Em seu levantamento bibliográfico sobre a arqueologia desta região, as autoras contabilizaram trinta e dois sítios arqueológicos, entre pré-coloniais e históricos. Porém, dessa data para cá, novas ocorrências arqueológicas foram registradas, principalmente, em decorrência de pesquisas arqueológicas realizadas por empresas de Arqueologia Preventiva.

\subsubsection{Ocorrência de sítios arqueológicos do Vale do Paraíba Paulista}

Entre os estudos arqueológicos realizados no Vale do Paraíba, podemos citar Scheuer (1957), Maranca (1969), Camargo e Camargo (1990); Cali (1999), Robrahn-González e Zanettini (1999), Caldarelli (2003), Gaspar, Barbosa e Cordeiro 
(2007), Lopes (2014) e outros. A partir da síntese apresentada por Lopes $(2014)^{2}$ com as ocorrências e sítios arqueológicos registrados no Vale do Paraíba e da busca por outras fontes diversas, elaborou-se a tabela 2, abaixo.

Tabela 2 - Ocorrências arqueológicas no Vale do Paraíba Paulista

\begin{tabular}{|c|c|c|c|}
\hline Município & Tipo / Descrição & $\begin{array}{c}\text { Ano de } \\
\text { identificação }\end{array}$ & Fonte \\
\hline Queluz & $\begin{array}{l}\text { Sítios Arqueológicos LITAU } 18 \text { e } \\
\text { LITAU } 19 \text { - lítico lascado }\end{array}$ & Não informado & $\begin{array}{l}\text { MILDER, s.d. Informação } \\
\text { disponibilizada no portal do } \\
\text { IPHAN - CNSA (2017) }\end{array}$ \\
\hline Cachoeira Paulista & $\begin{array}{l}\text { Sítios Arqueológicos LITAU 13, } \\
\text { LITAU 14, LITAU 15, LITAU } 16 \text { e } \\
\text { LITAU } 17 \text { - artefatos líticos e } \\
\text { cerâmicos }\end{array}$ & Não informado & $\begin{array}{l}\text { MILDER, s.d. Informação } \\
\text { disponibilizada no portal do } \\
\text { IPHAN - CNSA (2017) }\end{array}$ \\
\hline Canas & $\begin{array}{l}\text { Sítio Arqueológico - artefatos } \\
\text { líticos e cerâmicos }\end{array}$ & 2002 & $\begin{array}{l}\text { BORNAL \& QUEIROZ, 2002, } \\
2004 .\end{array}$ \\
\hline Lorena & $\begin{array}{l}\text { Sítios Arqueológicos LITAU } 10 \text { e } \\
\text { LITAU } 11 \text { - lítico lascado }\end{array}$ & Não informado & \begin{tabular}{|l} 
MILDER, s.d. Informação \\
disponibilizada no portal do \\
IPHAN - CNSA (201) \\
\end{tabular} \\
\hline Guaratinguetá & Fragmentos de cerâmica & 1969 & MARANCA, 1969 \\
\hline \multirow{3}{*}{ Aparecida } & Fragmentos de cerâmica & 1969 & MARANCA, 1969 \\
\hline & Fragmentos de cerâmica e ossos & De 1908 a 1979 & $\begin{array}{l}\text { CAMARGO \& CAMARGO, } \\
1990\end{array}$ \\
\hline & LITAU 8 e LITAU 9 - lítico lascado & Não informado & $\begin{array}{l}\text { MILDER, s.d. Informação } \\
\text { disponibilizada no portal do } \\
\text { IPHAN - CNSA (2017) }\end{array}$ \\
\hline \multirow[b]{2}{*}{ Roseira } & Fragmentos de cerâmica & 1969 & MARANCA, 1969 \\
\hline & $\begin{array}{l}\text { Duas jazidas arqueológicas com } \\
\text { cerâmica e objetos líticos }\end{array}$ & 1993 & PASIN, 1993 \\
\hline \multirow{3}{*}{ Taubaté } & $\begin{array}{l}\text { Urnas funerárias com ossadas } \\
\text { humanas }\end{array}$ & 1920 & ANDRADE, 1997 \\
\hline & $\begin{array}{l}\text { Peças de cerâmica contendo } \\
\text { ossadas }\end{array}$ & 1969 & ANDRADE, 1997 \\
\hline & $\begin{array}{l}\text { Sítios Arqueológicos LITAU 03, } \\
\text { LITAU 04 e LITAU } 07 \text { - lítico } \\
\text { lascado }\end{array}$ & Não informado & $\begin{array}{l}\text { MILDER, s.d. Informação } \\
\text { disponibilizada no portal do } \\
\text { IPHAN - CNSA (2017) }\end{array}$ \\
\hline \multirow[t]{2}{*}{ Pindamonhangaba } & $\begin{array}{l}\text { Orvalhinho - cerâmica pré- } \\
\text { histórica }\end{array}$ & 2008 & \begin{tabular}{|lr} 
DOCUMENTO & $(2008)$ \\
Informação disponibilizada \\
por Zanettini \\
(Informação pessoal)
\end{tabular} \\
\hline & $\begin{array}{l}\text { Sítio Borba Gato - cerâmica pré- } \\
\text { histórica e histórica }\end{array}$ & 2008 & $\begin{array}{ll}\text { DOCUMENTO } & (2008) \\
\text { Informação disponibilizada } \\
\text { por Zanettini } \\
\text { (Informação pessoal) }\end{array}$ \\
\hline \multirow{2}{*}{ Caçapava } & \begin{tabular}{|l|} 
Sítio Caçapava I - artefatos líticos \\
e cerâmicos
\end{tabular} & 1991 & $\begin{array}{l}\text { CALDARELLI, 2003; IPHAN, } \\
2017\end{array}$ \\
\hline & $\begin{array}{l}\text { Sítio Arqueológico - artefatos } \\
\text { líticos e cerâmicos }\end{array}$ & 2004 & CALDARELLI, 2007. \\
\hline
\end{tabular}

2 Todas as referências da tabela 2 constam na obra do autor, exceto os dados atualizados do site do IPHAN (2017) e mencionados por PASIN (1993) e por DOCUMENTO (2008) apud ZANETTINI (2017). 


\begin{tabular}{|c|c|c|c|}
\hline \multirow{9}{*}{$\begin{array}{l}\text { São José dos } \\
\text { Campos }\end{array}$} & $\begin{array}{l}\text { Vasilhas cerâmicas e artefatos } \\
\text { líticos (pontas de flecha e } \\
\text { machados polidos) }\end{array}$ & 1936 & TIBIRIÇA, 1936 \\
\hline & $\begin{array}{l}\text { Vasilhas cerâmicas (com } \\
\text { vestígios esqueletais) e artefatos } \\
\text { líticos }\end{array}$ & 1946 & $\begin{array}{l}\text { CROPANI \& NETO, } 1946 \\
\text { apud CALI, } 1999\end{array}$ \\
\hline & Fragmentos de cerâmica & 1969 & MARANCA, 1969 \\
\hline & $\begin{array}{lll}\text { Vasilhas } & \text { cerâmicas } & \text { (com } \\
\text { vestígios esqueletais) } & \end{array}$ & 1980 & CALLI, 1999 \\
\hline & Urna funerária & 1988 & \begin{tabular}{|l|} 
JORNAL \\
VALEPARAIBANO, 1991 \\
apud CALDARELLI, 2003 \\
\end{tabular} \\
\hline & $\begin{array}{l}\text { Vasilhas cerâmicas } \\
\text { superfície decorada) }\end{array}$ & 1991 & $\begin{array}{l}\text { JORNAL } \\
\text { VALEPARAIBANO, } 1991 \\
\text { apud CALDARELLI, } 2003 \\
\end{array}$ \\
\hline & \begin{tabular}{|lll} 
Vasilhas cerâmicas & (com \\
vestígios esqueletais) & \\
\end{tabular} & 2004 & MEDEIROS, 2004 \\
\hline & $\begin{array}{l}\text { Artefatos líticos lascados (pontas } \\
\text { de flechas) }\end{array}$ & $2001 / 2002$ & CALDARELLI, 2001/2002 \\
\hline & $\begin{array}{l}\text { Sítios arqueológicos Colinas, } \\
\text { Carcará e Pica-pau Amarelo }\end{array}$ & 2008 & A LASCA, 2012 \\
\hline \multirow{5}{*}{ Jacareí } & $\begin{array}{l}\text { Sítio Santa Marina - artefatos } \\
\text { líticos e cerâmicos }\end{array}$ & 1970 & $\begin{array}{l}\text { ANDREATTA, 1988; BLASI } \\
\text { \& GAISSLER, 1991; } \\
\text { ROBRAHN-GONZÁLEZ, } \\
\text { 1999; ZANETTINI } \\
\text { AQUEOLOGIA, 2010 } \\
\end{array}$ \\
\hline & $\begin{array}{l}\text { Sítio Pedregulho - artefatos } \\
\text { líticos e cerâmicos }\end{array}$ & 1998 & $\begin{array}{l}\text { SCATAMACHIA, } 1998 \text { apud } \\
\text { QUEIROZ, } 2011\end{array}$ \\
\hline & $\begin{array}{l}\text { Sítio Rio Comprido I - artefatos } \\
\text { líticos e cerâmicos }\end{array}$ & 1999 & CALLI, 1999 \\
\hline & $\begin{array}{l}\text { Sítio Villa Branca - artefatos } \\
\text { líticos e cerâmicos }\end{array}$ & 1998 & $\begin{array}{l}\text { ZANETTINI/DOCUMENTO, } \\
\text { 1998; } \quad \text { ZANETTINI } \\
\text { ARQUEOLOGIA, } 2010 \\
\end{array}$ \\
\hline & $\begin{array}{l}\text { Sítio Light - artefatos líticos e } \\
\text { cerâmicos }\end{array}$ & 2000 & CALLI, 1999 \\
\hline \multirow{2}{*}{ Paraibuna } & Sítio Arqueológico Ribeiro & 2009 & $\begin{array}{l}\text { MORAIS, } 2009 \\
\text { LOPES, } 2014\end{array}$ \\
\hline & Sítio sem nome & 2013 & $\begin{array}{l}\text { BORNAL, } 2013 \\
\text { LOPES, } 2014 .\end{array}$ \\
\hline
\end{tabular}

Fonte: Adaptado de Lopes (2014).

Estudos arqueológicos sistemáticos no Vale do Rio Paraíba Paulista foram iniciados por Herta Löel Scheuer, na década de 1950. Trabalhos desenvolvidos por ela, em 1957, revelaram fragmentos de cerâmica no município de Aparecida (BORNAL, 1999; CALI, 1999). Manchas de terra preta e, aproximadamente, quarenta vasos destruídos, alguns com ossos humanos, teriam sido encontrados no "Largo da Freira", em 1935. (SCHEUER, 1957 apud BORNAL, 1999).

Posteriormente, o município foi estudado por Conceição Borges Ribeiro de Camargo e Vicente de Camargo, que relataram diversos achados arqueológicos em 
publicação de 1990, intitulada "Arqueologia no Vale do Paraíba - Escavações Arqueológicas em Aparecida". Em 1908, quando da realização de obras no pátio da antiga Estação de Ferro Central do Brasil, teria aparecido a primeira igaçaba (com esqueleto em posição vertical) na região; em 1928, na Rua Ladeira Monte Carmelo, teria sido encontrada outra igaçaba com tampa e ossos; outras ocorrências arqueológicas, na maioria vasilhas cerâmicas, com exceção de um cachimbo e de um machadinho em forma de ancora, foram descobertos entre os anos de 1935 e 1979. (CAMARGO; CAMARGO, 1990).

No final da década de 1970, no município de Jacareí, foi identificado o Sítio Santa Marina, que foi estudado por Oldemar Blasi e Miguel Gaissler, do Museu Paraense, em 1991 e resultou na coleta de mais de 10.000 fragmentos de cerâmica, duas dezenas de artefatos líticos polidos (lâminas de machado) e um pouco de material lítico lascado (lascas e raspadores). Após, em 1999, o mesmo, que vinha sendo "degradado" por obras de um loteamento residencial, voltou a ser escavado, dessa vez, sob a coordenação de Erika M. Robrahn-Gonzalez e Paulo E. Zanettini, após a elaboração de TAC. Para impedir que outros sítios arqueológicos fossem destruídos ou impactados, devido a outras obras, dentro do território desse município foram estabelecidas áreas de interesse arqueológico. Assim, outros três sítios (localizados em áreas de loteamentos) foram identificados: Sítio Mirante do Vale, Sítio Pedregulho e Sítio Villa Branca. (BORNAL, 1999).

O material arqueológico escavado, no final da década de 1990, é constituído por 2 peças líticas polidas, 5 peças líticas lascadas e 1.958 peças cerâmicas, sendo uma urna funerária, relacionadas a tradição Tupiguarani. A distribuição do material mostra que o cerâmico se concentrou nas áreas de manchas escuras (prováveis locais de cabanas) e as duas datações por carbono 14 indicaram a ocupação desse sítio no século XV (1.400 a 1475 anos Dc.). (ROBRAHNGONZÁLEZ; ZANETTINI, 1999). No final de 2009 e início de 2010, o Sítio Santa Marina foi submetido a uma terceira etapa de escavação, sob a responsabilidade da empresa Zanettini Arqueologia. Nesse momento, foram coletados 41 artefatos líticos e 8.476 fragmentos de cerâmica, sendo que mais da metade estava sobre área de mancha de terra preta. A análise do material escavado em mais de uma etapa, permitiu associá-lo a uma ocupação Tupinambá, composta por vários grupos étnicos (LOPES, 2014). 
Em visita ao Museu Histórico e Pedagógico Dom Pedro I e Dona Leopoldina, em Pindamonhangaba, descobriu-se que na reserva técnica há algumas amostras de material lítico polido, porém, sem registro exato de sua procedência. No catálogo do museu, disponível no site da prefeitura, esse material está identificado como "pedra de raio" e "Ferramenta lítica (Pedra-de-raio)" e as quatro peças tem dimensões, em centímetros, de 29 × 04 × 23, 09 × 08 × 19, 09 × 04 × 24 e $08 \times 04$ × 14. (MUPI, 2017).

Em Pindamonhangaba, foram identificados dois sítios pré-coloniais cerâmicos, durante a execução de pesquisa arqueológica para fins de licenciamento ambiental, coordenada pela empresa DOCUMENTO, em 2008 (ZANETTINI, 2017), porém, esse dado não consta no Cadastro Nacional de Sítios Arqueológicos - CNSA e também não estava na relação de processos lidos no IPHAN, sobre as ocorrências arqueológicas desse município e áreas vizinhas. O fato desses sítios terem sido localizados há cerca de dez anos atrás e suas informações básicas ainda não estarem disponíveis para consulta, nos faz acreditar que possam existir outros sítios arqueológicos na região, ou mesmo no município, identificados, porém, não registrados no banco de dados do CNSA.

De qualquer forma, foram consultados, pessoalmente, todos os processos disponíveis na sede da Superintendência Estadual do IPHAN de São Paulo, durante o segundo semestre de 2017, referentes as pesquisas arqueológicas no município de Pindamonhangaba, e essa busca revelou a existência de apenas um sítio histórico, denominado Sítio Ribeirão Grande. O mesmo foi identificado em 1992, registrado no IPHAN em 1994, e submetido a pesquisa arqueológica por uma equipe coordenada por Margarida Andreatta, entre 2007 e 2013, período no qual também foi desenvolvido um programa de educação patrimonial junto à comunidade, com foco no público escolar. (ANDREATTA et al, 2014).

Até 2016, apenas oito projetos de pesquisa arqueológica para fins de licenciamento ambiental, com finalidades distintas (loteamentos, implantação de sistema de esgoto, de indústrias e de terminais), que foram executados no município de Pindamonhangaba, estão disponíveis para consulta. Em quatro deles foram realizadas atividades de prospecção de subsuperfície, porém, nenhum material arqueológico foi encontrado. (IPHAN, 2017). Como não há dados sobre as profundidades alcançadas, ou os métodos utilizados para a realização das 
sondagens, é difícil afirmar que todas essas áreas, de fato, não apresentam potencial arqueológico. Em alguns casos, pela leitura do relatório, não é possível saber sequer a localização das intervenções / sondagens realizadas.

\subsubsection{Pesquisas arqueológicas em andamento na área de estudos}

Entre 2016 e 2017 foram abertos e estão em andamento quatorze processos de pesquisa arqueológica, sendo quatro relacionados a obras de loteamento residencial, um sobre assentamento rural e um sobre tratamento de resíduos. Os demais dizem respeito a extração mineral de areia e saibro. (IPHAN, 2017). A mesma pesquisa também foi feita para os municípios limítrofes que constam na área de estudo. Logo, entre processos diversos de estudos arqueológicos, disponíveis no órgão, para consulta, foram encontrados: três processos em Potim, sete em Aparecida, oito em Roseira e três em Guaratinguetá. Neste município, há ainda registro de sete processos anteriores a 2016, porém, alguns não puderam ser consultados por estarem em outros setores do IPHAN, para análise. (IPHAN, 2017).

A existência dessas pesquisas arqueológicas, em andamento, aumenta a perspectiva de que sejam realizadas outras prospecções arqueológicas na área estudada e, talvez, seja encontrado material arqueológico. Como demonstrado acima, a maior parte dos processos constitui-se de estudos em área de terraço fluvial, onde é extraída a areia para fins comerciais. E embora esta pesquisa indique que tais áreas têm menos potencial arqueológico em superfície, devido a dinâmica do rio, que afeta as suas margens, acredita-se que em maiores profundidades pode haver material arqueológico depositado, especialmente no nível d'água, ou até abaixo dele. Afinal, tais áreas que, hoje, constituem os depósitos de areia, constituíram no passado, o antigo leito do rio.

\subsubsection{Tradições arqueológicas do Vale do Paraíba}

Até o momento, dois grupos nativos pré-coloniais, relacionados a tradições ceramistas, são apontados como "predominantes" no Vale do Paraíba: Tupiguarani (tronco linguístico Tupi) e Aratu (tronco linguístico Macro-Jê). De acordo com A LASCA (2011), o Sítio Carcará apresenta ainda características que possibilitam relacioná-lo a 
Tradição Itararé-Taquara. Tal sítio, mencionado anteriormente como Paleoíndio, teria sido ocupado em dois momentos, primeiramente por grupos caçadores-coletores e, posteriormente, por grupos horticultores/agricultores ceramistas.

A ocupação do Vale do Paraíba Paulista por grupos caçadores-coletores foi registrada, inicialmente, no município de São José dos Campos, por Ruy Tibiriçá, em 1936, ao descrever o encontro de pontas de flecha e machados polidos na antiga Chácara Boa Vista. (TIBIRIÇA, 1936 apud LOPES, 2014). A ocorrência de peças líticas lascadas (pontas de projétil bifaciais) no Distrito de São Francisco Xavier, no mesmo município, também é mencionada por Caldarelli (2001/2002), como um dado fornecido por Wagner Bornal.

O termo "tradição", dentro de um contexto arqueológico, vem sendo empregado no Brasil desde a década de 1960, a partir da implantação do PRONAPA e refere-se a um "grupo de elementos ou técnicas que se distribuem com persistência temporal". (PRONAPA, 1976, apud ARAUJO, 2001). Embora a nomenclatura "tradição arqueológica" (assim como "fase") seja amplamente empregada na bibliografia para relacionar a cultura material aos grupos humanos que a produziram, ressalta-se que esse "conceito" é motivo de discussão entre alguns arqueólogos, quanto ao seu significado e abrangência.

A seguir, as três "tradições" ceramistas, mencionadas acima são sumariamente descritas quanto a sua produção material e área de ocorrência. A Tradição Aratu caracteriza-se pela "presença de cerâmica não decorada, com antiplástico mineral, uso ocasional de incisão simples nas bordas, urnas funerárias piriformes, vasilhas globulares, hemisféricas, formas duplas e vasilhas com bordas onduladas." (CALDARELLI, 2003, p. 221). Além do Sudeste (Espírito Santo, Minas Gerais e São Paulo) sua ocorrência, no território brasileiro, também se dá no litoral nordestino (Bahia, Sergipe, Alagoas, Rio Grande do Norte e Ceará) e nos estados de Mato Grosso e Goiás (CALDARELLI, 2003).

Com relação à Tradição Tupiguarani, Lopes (2014), remetendo-se a Chmyz (1976), a descreve como "caracterizada pela presença de cerâmica policrômica (vermelho ou preto sobre engobo branco e/ou vermelho), com acabamento corrugado e escovado, além dos enterramentos secundários em urnas, os machados de pedra polida e a presença de tembetás" (CHMYZ, 1976, apud LOPES, 2014, p.62). 
Esta tradição encontra-se espalhada por grande parte do território brasileiro e ultrapassa suas fronteiras, sendo apontada em países como Paraguai, Argentina e Uruguai. (ARAUJO, 2001). De acordo com o tipo de decoração, pode ser dividida em três "subtradições", que são Pintada, Corrugada e Escovada (PRONAPA, 1969 apud ARAUJO, 2001).

Quanto à Tradição Itararé-Taquara, ressalta-se a longa discussão quanto à origem de sua denominação, que, segundo Araujo (2007) estaria relacionada à semelhança de características de três tradições: Itararé, Casa de Pedra e Taquara. Assim, definem-se: a Tradição Itararé, por sua cerâmica composta por "vasilhames pequenos e finos com pouca variação nas formas, geralmente sem decoração e apresentando cores entre marrom escuro, cinza e negro" (CHMYZ, 1968a apud ARAUJO, 2007, p.13) e a "Fase" Taquara (que depois foi confirmada como "Tradição Taquara" pelo PRONAPA em 1969) como "associada a "casas subterrâneas" que são depressões doliniformes provavelmente escavadas com o intuito de fornecer abrigo" (MILLER, 1967 apud ARAUJO, 2007, p.13). Sua área de ocorrência abrange os estados da região Sul (Rio Grande do Sul, Santa Catarina e Paraná), São Paulo e também o nordeste da Argentina (ARAUJO, 2007).

Distribuídos nos municípios de Canas, Mogi das Cruzes e Jacareí, constam, no Vale do Paraíba, seis sítios arqueológicos que abrigam cerâmica, artefatos líticos, lascados e polidos e que estão relacionados à Tradição Tupiguarani. São eles: o Sítio Caninhas, em Canas, o Sítio Taboão 2, em Mogi das Cruzes e os sítios Santa Marina, Pedregulho, Vila Branca e Rio Comprido, localizados no município de Jacareí (GASPAR; BARBOSA; CORDEIRO, 2007).

O Sítio Rio Comprido, foi escavado por Plácido Cali, em 1998 e além de material arqueológico classificado como "cerâmica indígena" (151 fragmentos), também apresentou 15 fragmentos de cerâmica neobrasileira e 8 de faiança. (CALLI, 1999).

O sítio arqueológico Caninhas, identificado em 2002, em área destinada à construção de casas populares, no município de Canas, apresentou estruturas funerárias preenchidas por cerâmicas e de combustão e também material cerâmico (fragmentos e tigelas) com acordelamento e pinturas (em bom estado de conservação) geométricas na cor vermelha, branca e preta, características que o 
relacionam com a Tradição Tupi-guarani (BORNAL e QUEIROZ, 2005 apud SANTOS; SENA, 2010).

Achados fortuitos de vestígios arqueológicos, ligados a esta tradição, também foram registrados nos municípios de São José dos Campos e Roseira, Guaratinguetá e Aparecida. Maranca (1969) afirma que o material coletado por ela nos arredores de Aparecida, Roseira e Guaratinguetá não é Tupi, ao contrário do material existente no Museu Paulista, que teria sido encontrado no Vale do Paraíba, antes dela.

Como representantes da Tradição Aratu, nesta região, têm-se: o Sítio Caçapava I, em Caçapava, o Sítio Light, em Jacareí, o Sítio Natividade da Serra I, em Natividade da Serra, o Sítio Colinas, em São José dos Campos e o Sítio Aparecida, no município de mesmo nome (GASPAR; BARBOSA; CORDEIRO, 2007). Nesse "grupo", Lopes (2014) ainda aponta dois sítios em Paraibuna (Sítio Ribeiro e sítio sem nome).

\subsubsection{Locais preferenciais de ocupação no Vale do Paraíba}

Com relação à geomorfologia, e remetendo-se a ideia de fator-geo, destaca-se a escolha do local de assentamento dos sítios. O emprego de parâmetros que permitem o mapeamento das áreas potencialmente favoráveis ao encontro de sítios arqueológicos é apontado por Morais (1999) nos estudos arqueológicos da Bacia do Rio Paranapanema e, por analogia, podem ser úteis para a Região do Vale do Paraíba. Este autor observa, porém, que tais parâmetros devem ser reavaliados caso se queira incorporar situações relativas ao período pós conquista europeia, devido às alterações da ordem econômica e social das comunidades indígenas.

Ao analisar vários parâmetros ligados à função "morar" (terraços fluviais, vertentes, patamares de vertentes, cabeceiras de nascentes, topos de interflúvios e escarpas), faz-se um paralelo com alguns sítios do Vale do Paraíba, anteriormente mencionados, e que se encontram em estruturas morfológicas semelhantes.

Assim, a preferência por lugares mais altos é evidenciada nos seguintes exemplos de sítios: Santa Marina e Sítio Caçapava, ambos localizados no topo de um planalto, a 650 e a 580 metros acima do nível do mar, respectivamente. O Sítio Light (632 metros acima do nível do mar), situado na divisa entre Jacareí e Santa Branca 
também está parte no topo e parte nas vertentes de uma colina, com média declividade, junto a Represa de Santa Branca (IPHAN, 2014). Segundo Gaspar, Barbosa e Cordeiro (2007) seria este o único sítio da região cuja porção se encontra as margens do Rio Paraíba do Sul (da represa). Uma hipótese para este sítio, em particular, poderia ser o advento da construção da barragem que represou a água trazendo-a, posteriormente, para local mais próximo ao sítio. Por fim, Maranca (1969) afirma que todos os sítios pesquisados por sua equipe, nos arredores de Aparecida, Guaratinguetá e Roseira, encontram-se sobre colinas de 525 metros, no primeiro nível de colinas acima do terraço fluvial.

Sobre a questão da matéria-prima utilizada para a confecção de artefatos líticos achados nos sítios da região, por exemplo, sabe-se que a maior parte se encontra disponível no solo vale paraibano. No sítio Santa Marina, Lopes (2014) identificou artefatos constituídos de "sílex, quartzo leitoso, quartzito, arenito (friável e férrico), gnaisse e quartzo policristalino." (p.154). Ainda de acordo com o pesquisador, com exceção do sílex (que pode ter sido transportado de outras localidades), as demais matérias-primas estão presentes em um raio de dez quilômetros do sítio escavado.

Em relação à cerâmica produzida nestes sítios, a busca por sua matériaprima traz o mesmo tipo de reflexão, ou seja, a argila (barro "bom") utilizada na produção de vasos, urnas funerárias e outros artefatos, é mineral constituinte dos tipos de solo da região vale paraibana. A produção cerâmica nos sítios do Vale do Paraíba é apontada em todos os casos. O estilo, bem como a fonte mineral, o formato e as possíveis formas de utilização destes artefatos foram comparados por Caldarelli (2003), Lopes (2014) e outros e tais parâmetros Ihes permitiram inferir a ligação deles com determinadas tradições (Aratu, Tupiguarani ou Itararé-Taquara). Sendo este mais um exemplo do resultado de uma abordagem no macro-nível.

Esta breve discussão apresentada sobre os sítios arqueológicos conhecidos na região do Vale do Paraíba e a relação deles com as características fisiográficas da paisagem evidencia a importância do emprego da Geoarqueologia como abordagem teórica no estudo de sítios arqueológicos já conhecidos e que podem vir a ser "encontrados". 


\section{PROCEDIMENTOS METODOLÓGICOS}

A seguir, faz-se uma descrição detalhada do processo seguido para a construção do mapa de potencial arqueológico, bem como das técnicas utilizadas do decorrer da pesquisa. A construção do mapa preliminar de potencial arqueológico demandou a seguinte sequência de operações:

a) Análise de cartas topográfica e geológica do município de Pindamonhangaba, nas escalas 1:50.000 e de 1:10.000;

b) Uso de aplicativo de visualização de imagens de satélite - Google Earth - para identificação das formas de relevo de interesse arqueológico e para marcação de pontos com as respectivas coordenadas geográficas;

c) Análise de fotografias aéreas do município acima mencionado, por meio da estereoscopia;

d) Elaboração de perfis topográficos;

e) Elaboração de carta hipsométrica na escala de 1:50.000;

f) Desenho das depressões circulares interfluviais em overlay sob o efeito da estereoscopia;

g) Digitalização dos overlays e georreferenciamento das fotos sobre eles;

h) Vetorização da drenagem principal;

i) Classificação das depressões quanto ao tamanho e distância do rio Paraíba;

j) Distinção entre áreas inundáveis e áreas não inundáveis por meio das cotas altimétricas;

k) Construção de banco de dados com informações sobre localização das depressões, colinas e áreas não inundáveis;

I) Plotagem de dados e elaboração de mapa preliminar de áreas de potencial arqueológico por meio do uso do software "ArcGIS";

\subsection{USO DE IMAGENS DE SATÉLITES EM MAPEAMENTO}

A consulta ao material cartográfico da área de estudos foi o ponto de partida para o reconhecimento da região. Logo, a carta de 1:50.000 do Município de Pindamonhangaba (1974) foi sido utilizada com frequência, concomitantemente, ao 
uso do programa Google Earth para a identificação de depressões, possíveis lagoas isoladas, bem como a sua distinção de açudes e/ou cabeceiras de drenagem.

A partir dos limites da carta topográfica, foi estabelecido um recorte correspondente no Google Earth, por meio de quatro linhas de identificação que formaram um retângulo e delimitaram a área de interesse.

A medida que as depressões foram identificadas no Google Earth (vide figura 10), uma tabela em Excel foi elaborada com suas respectivas coordenadas UTM. A primeira depressão localizada e marcada foi denominada D1, a segunda D2 e assim, sucessivamente. A princípio, tentou-se seguir um padrão de varredura linear, de modo que o primeiro conjunto de depressões identificado foi o que se encontra no intervalo de coordenadas UTM: Latitudes $7464 \mathrm{Km} \mathrm{S}-7462 \mathrm{Km}$ S e Longitudes 450 $\mathrm{Km} \mathrm{E}-474 \mathrm{Km} \mathrm{E}$ (na verdade, o limite Leste da carta inicia-se antes dos $450 \mathrm{Km}$ ). $\mathrm{O}$ segundo conjunto deveria abranger os dois quilômetros seguintes em direção a Sul (7462 Km S - $7460 \mathrm{Km} \mathrm{S}$ ) no sentido latitudinal, bem como o trecho correspondente ao mesmo recorte longitudinal $(450 \mathrm{Km} \mathrm{E}-474 \mathrm{Km} \mathrm{E}$ ), cerca de vinte quatro quilômetros. Porém, devido a uma característica do próprio programa, conforme a tela era arrastada para um dos lados, para se visualizar as demais depressões, a orientação (N-S) ou (L-O), tendia a se alterar. Logo, esses limites são "aproximados" e a localização das depressões nem sempre correspondia a sequência numérica. Ao fim do mapeamento preliminar, todas as depressões foram renumeradas, obedecendo o critério de distinção segundo a margem do rio Paraíba, ou seja, primeiramente, foram renumeradas as da margem direita e, posteriormente, as da margem esquerda. 
Figura 10 - Identificação preliminar das depressões

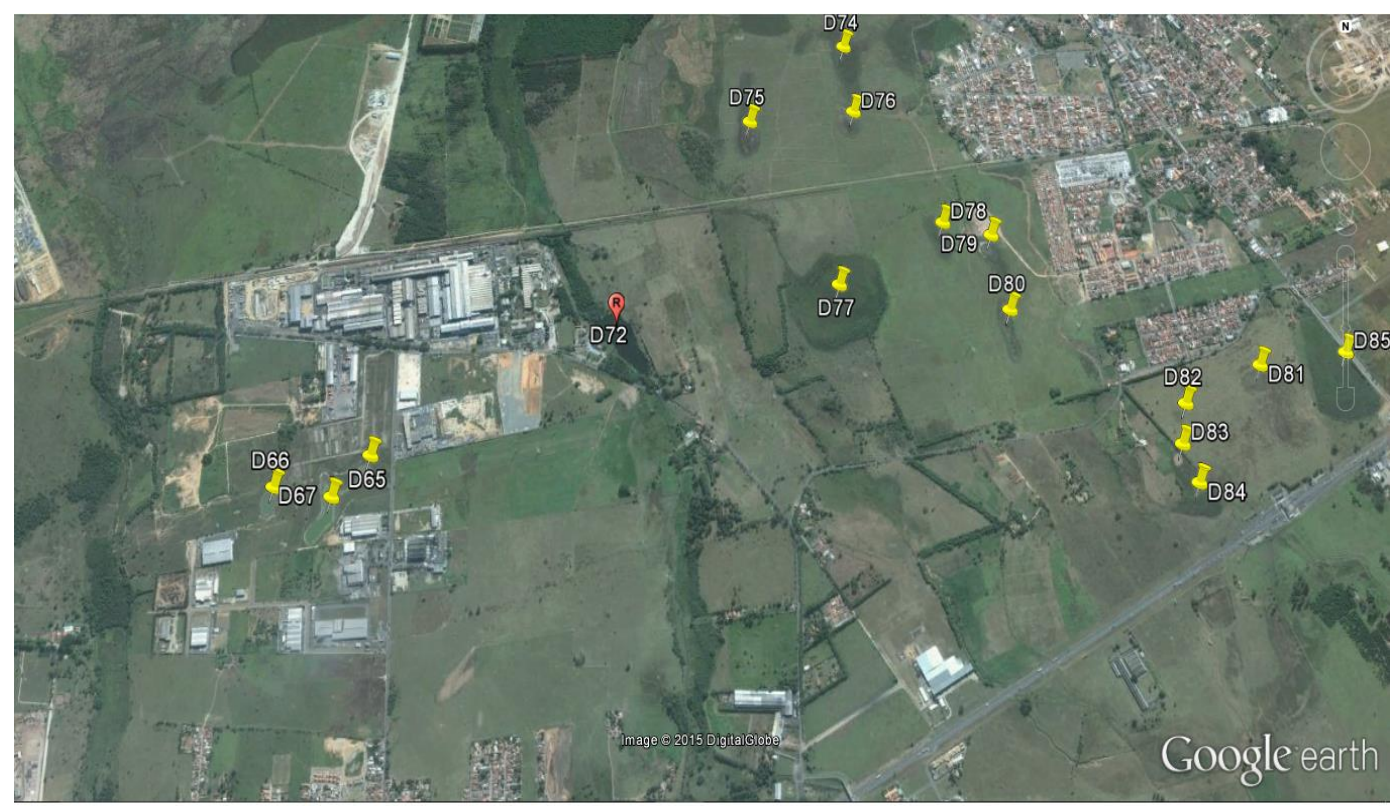

Fonte: Google Earth. Org.: Leal (2015).

Muitas dessas feições geomorfológicas que vinham aparecendo nas imagens do Google Earth, não constavam na carta topográfica de 1:50.000, devido a escala, ao mesmo tempo que também existiam dúvidas quanto a sua identificação, ou seja, pela imagem do Google Earth, não era possível ter certeza se determinada feição se tratava, de fato, de uma depressão ou não.

\subsection{A FOTOINTERPRETAÇÃO AÉREA}

Sabendo-se que a estereoscopia poderia resolver algumas questões, por possibilitar uma visão tridimensional dos elementos da paisagem, optou-se também pela consulta às fotografias aéreas de Pindamonhangaba, na escala de 1:25.000, do ano de 1962. Este acervo fotográfico pertence ao LASERE - Laboratório de Sensoriamento Remoto da USP, local onde começou a ser examinado. Devido à reforma que ocorreu no LASERE, fato que impediu seu acesso por algum tempo, as fotografias passaram a ser analisadas no LABOPED - Laboratório de Pedologia da USP.

A análise dessas fotografias permitiu reconhecer as depressões que outrora eram dúvidas, no entanto, as formas de algumas delas levaram a outros questionamentos. Um grupo de três lagoas (como mostra a figura 11), localizado a 
cerca de trinta metros do Rio Paraíba do Sul chamou a atenção, tanto por, aparentemente, estarem alinhadas, quanto pelas formas alongadas e curvadas, o que nos fez pensar na possibilidade de serem meandros abandonados.

Para sanar essa e demais dúvidas, recorreu-se a literatura e a revisão bibliográfica nos apontou, novamente, os estudos de Filizola (1993) sobre depressões circulares localizadas nos municípios de São José dos Campos e Caçapava, na Região do Vale do Paraíba. Durante a análise desta obra, percebeu-se a necessidade de olhar também as fotos aéreas utilizadas por esta autora (na mesma escala e do mesmo ano), afim de comparar as depressões.

De acordo com as imagens observadas e com a discussão apresentada por Filizola, existe alinhamento entre as depressões no Vale do Paraíba. A origem dele, porém, não está bem clara, a não ser por uma nota sobre a dificuldade em "explicar estes alinhamentos sem a intervenção de falhas" (p.83). Segundo mapa de alinhamento dessas depressões circulares, a autora constata que nos cruzamentos dos alinhamentos traçados existe uma depressão, o que a leva a concluir "que as depressões se formam na vertical dos cruzamentos de falhas" (FILIZOLA, 1993, p. 83).

Embora a causa do alinhamento não tenha sido esclarecida, nesse estudo, a semelhança morfológica das depressões comparadas foi confirmada, visualmente, durante a observação das fotografias aéreas de ambos os municípios.

Outra alternativa para a falta de detalhes, decorrente do uso da carta topográfica na escala de 1:50.000, foi a aquisição no IGC - Instituto de Geociências de São Paulo - de cartas topográficas na escala de 1:10.000. Em razão do elevado custo de cada carta, tornou-se inviável adquirir todos os recortes necessários, por isso, foram solicitadas apenas cinco cartas, que abrangem a área delimitada no Google Earth com a maior densidade de possíveis lagoas. 
Figura 11 - Conjunto de lagoas no município de Pindamonhangaba, cuja aparência assemelhase a de meandros abandonados.

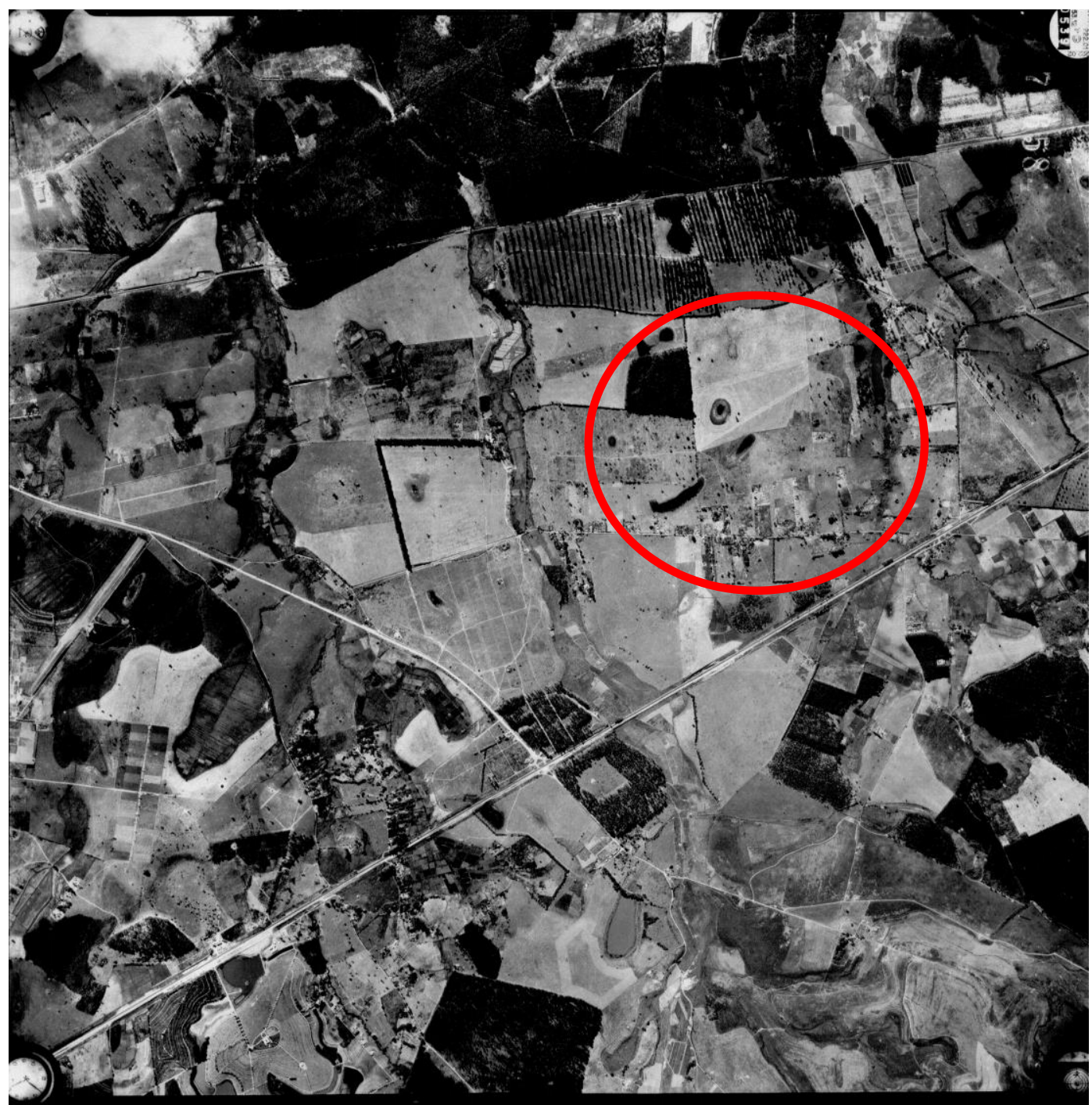

Fonte: Secretaria de Agricultura do Estado de São Paulo - Instituto Agronômico. (1962). Escala aproximada da foto: 1.25.000. Aerofoto Natividade Ltda. Foto n. 6584. Org. Leal (2015).

Foram utilizadas três ferramentas de análise distintas, ao mesmo tempo: seis cartas topográficas, sendo uma na escala de 1:50.000 e cinco na escala de 1:10.000, 121 fotografias aéreas na escala aproximada de 1:25.000 e o Google Earth. A presença das depressões (possíveis lagoas), identificada, primeiramente no Google Earth, foi checada nas cartas de 1:10.000. Quando houve dúvida sobre sua morfologia, fez-se a estereoscopia das fotos aéreas. Após confirmados, esses pontos de interesse foram plotados no Google Earth.

Após a revisão de todo o conjunto, no momento do seu desenho, elas foram classificadas em três categorias: naturais, em área urbanizada e duvidosas. Esta última categoria foi atribuída ao conjunto cuja origem natural não pode ser confirmada. 
As que foram consideras represamentos por suas características não naturais foram descartadas.

Depois do processo de classificação e análise dos dados relacionados às depressões, passou-se para a identificação das colinas, tais como a que está situada o Sítio Carcará, único sítio Paleoíndio da região, no município de São José dos Campos. No total, foram identificadas 13 colinas (vide tabela 3), distribuídas em ambas as margens do rio Paraíba, próximas às serras do Mar e da Mantiqueira.

Tabela 3 - Localização das colinas

\begin{tabular}{c|c|c}
\hline Identificação & Longitude & Latitude \\
\hline Colina 1 & 462154 & 7461555 \\
\hline Colina 2 & 463715 & 7462455 \\
\hline Colina 3 & 472713 & 7470740 \\
\hline Colina 4 & 473385 & 7470566 \\
\hline Colina 5 & 473335 & 7471382 \\
\hline Colina 6 & 450491 & 7469739 \\
\hline Colina 7 & 453141 & 7472103 \\
\hline Colina 8 & 453059 & 7473411 \\
\hline Colina 9 & 455276 & 7473556 \\
\hline Colina 10 & 456927 & 7474169 \\
\hline Colina 11 & 454424 & 7475564 \\
\hline Colina 12 & 451188,62 & 7475520,35 \\
\hline Colina 13 & 465146 & 7481821 \\
\hline
\end{tabular}

Fonte: Leal (2017).

A carta geológica de Pindamonhangaba também foi usada para o destaque de feições geológicas relevantes e para comparar a litologia deste município com o de São José dos Campos, onde foi comprovada a existência do mesmo tipo de depressão.

\subsection{TÉCNICAS DE AFERIÇÃO DO TAMANHO DAS DEPRESSÕES}

Entre os diversos atributos das depressões identificadas na área de estudo, para uma interpretação arqueológica, julgou-se mais relevante o tamanho delas, pois, supõe-se que as maiores reúnem mais atrativos para os povos pretéritos, tais como: piscosidade, mais chances de não secar, maior poder de atração de animais para suas margens, que significa fonte de alimento, entre outros.

Para se aferir o tamanho das depressões, primeiramente, tentou-se utilizar a ferramenta do Google Earth "caminho", de modo que um ponto inicial era marcado 
e "puxava-se" a linha até a extremidade da depressão, onde se marcava outro ponto. Duas linhas eram traçadas, eixo maior e eixo menor e suas medidas eram divididas, para se calcular um índice (maior ou menor que 1) e assim, determinar seu formato (elíptica, circular ou irregular). Para ser considerada circular estabeleceu-se o valor menor ou igual a 1 (um), as "arredondadas, com índice maior que um seriam consideradas elípticas, e as demais, classificadas como irregulares.

Porém, durante o processo de medição desses eixos, notou-se que a mancha escura, que delimitava os limites da depressão, nem sempre estava visível. A foto aérea de 1962 indicava sua existência, mas a imagem atual, de satélite, muitas vezes, não. A alteração do terreno no qual está a depressão, tanto para a construção de residenciais ou uso industrial, como para o cultivo de eucaliptos são fatores que dificultaram sua visualização. Ademais, mesmo que não existissem essas questões, chegou-se a constatação que a mancha escura evidenciada na imagem do Google Earth é indicativo apenas de área úmida, mas não permite inferir a área de captação de água dessa depressão.

Como só a estereoscopia das fotos aéreas pode mostrar, com precisão, os limites de uma depressão, considerou-se medir a área das depressões com base nas fotos e não mais no Google Earth.

O cálculo direto da área das depressões, sem estereoscopia, apenas pela aplicação da fórmula da escala $(E=D / d$, onde $E=$ escala, $D=$ Distância Real e $d=$ distância do desenho), não é viável pois a escala da foto é aproximada e seria necessário corrigir a distorção da imagem obtida remotamente.

No entanto, sabendo-se que uma depressão pode ser considerada, de modo geral, como uma "mini bacia endorreica", pensou-se no uso de duas técnicas distintas, comumente utilizadas no cálculo da área de uma bacia hidrográfica: a planimetria e a pesagem do papel em balança de precisão.

A planimetria consiste em contornar uma área plana com um aparelho denominado planímetro. Após, multiplica-se o valor registrado no aparelho $(\mathrm{L}=$ Leitura) pelo valor da escala da carta utilizada, elevado ao quadrado $\left(E^{2}\right)$. O resultado é dividido por uma constante relacionada às dimensões do aparelho $(K)$ : Área $=\mathrm{L} x$ $E^{2} / 2$.

A pesagem se dá pela comparação de uma área cujo peso e dimensão são conhecidos com outra área da qual se obtém o peso e se quer saber o tamanho. 
Além da dificuldade em passar o planímetro em todas as depressões, algumas bem pequenas, a técnica da "pesagem" foi escolhida por também viabilizar outros benefícios. Um deles foi a possibilidade de ilustrar as diferentes formas "reais" das depressões, algo não viável durante a tentativa inicial de reduzi-las a apenas três classes de formatos. Outra vantagem foi a oportunidade de rever cada depressão e definir se, para este estudo, ela pode ser considerada uma depressão natural ou não. Nessa segunda análise com o estereoscópio, muitas foram classificadas como barramentos artificiais, e, portanto, descartadas como áreas de potencial arqueológico.

Logo, o primeiro passo foi medir um $1 \mathrm{~cm}^{2}$ no papel ultrafan e recortá-lo. Em seguida, o mesmo foi pesado em balança de precisão e o valor em gramas foi anotado. Esse quadrado tornou-se nosso parâmetro (área e pesos conhecidos).

O segundo passo foi separar as fotografias aéreas nas quais apareciam as depressões. Sobre uma delas, que formava o par necessário a estereoscopia, foi posicionado um pedaço de papel ultrafan. A partir da visualização do limite da depressão, seu contorno foi desenhado sobre o overlay. Muitas vezes, o limite de uma depressão coincidiu com o limite da depressão ao lado.

Após, foram tiradas cópias de todos os overlays e nelas foram identificadas as depressões por meio da numeração inicial.

Pretendeu-se realizar o terceiro passo, que consiste em recortar todas as depressões desenhadas e pesá-las na balança de precisão. Os valores aferidos seriam multiplicados pelo valor do quadrado de $1 \mathrm{~cm}$. Como a escala da foto é aproximada (1:25.000), um valor mais próximo do real foi calculado, a partir de uma depressão de uma carta topográfica na escala de 1:10.000, que também aparece na foto. Por fim, os valores de área aferidos no terceiro passo, seriam multiplicados pelo novo valor da escala das fotografias aéreas.

Uma primeira sequência de depressões, com 15 exemplos, foi recortada, pesada e foi calculada sua dimensão. Porém, notou-se que os valores obtidos estavam fora do esperado, mostrando que as depressões seriam bem maiores que o imaginado. Muitos fatores podem interferir no cálculo nesse caso. Um deles é a precisão do recorte sobre o tracejado, que pode resultar em milímetros a mais e que equivalem a metros a mais, no final. Outro fator é a precisão da balança e sua 
calibração. Assim, visando diminuir a margem de erro, optou-se por utilizar outra técnica de medição, a partir dos desenhos das depressões.

\subsection{O USO DE GIS NA PESQUISA ARQUEOLÓGICA}

A técnica escolhida consistiu no escaneamento dos "layers" com os desenhos das depressões, junto com as respectivas fotografias aéreas. Vide figura 12. Para garantir que todas as feições fossem representadas nos respectivos layers, algumas tiveram que ser redesenhadas.

Figura 12 - Foto aérea digitalizada com o layer

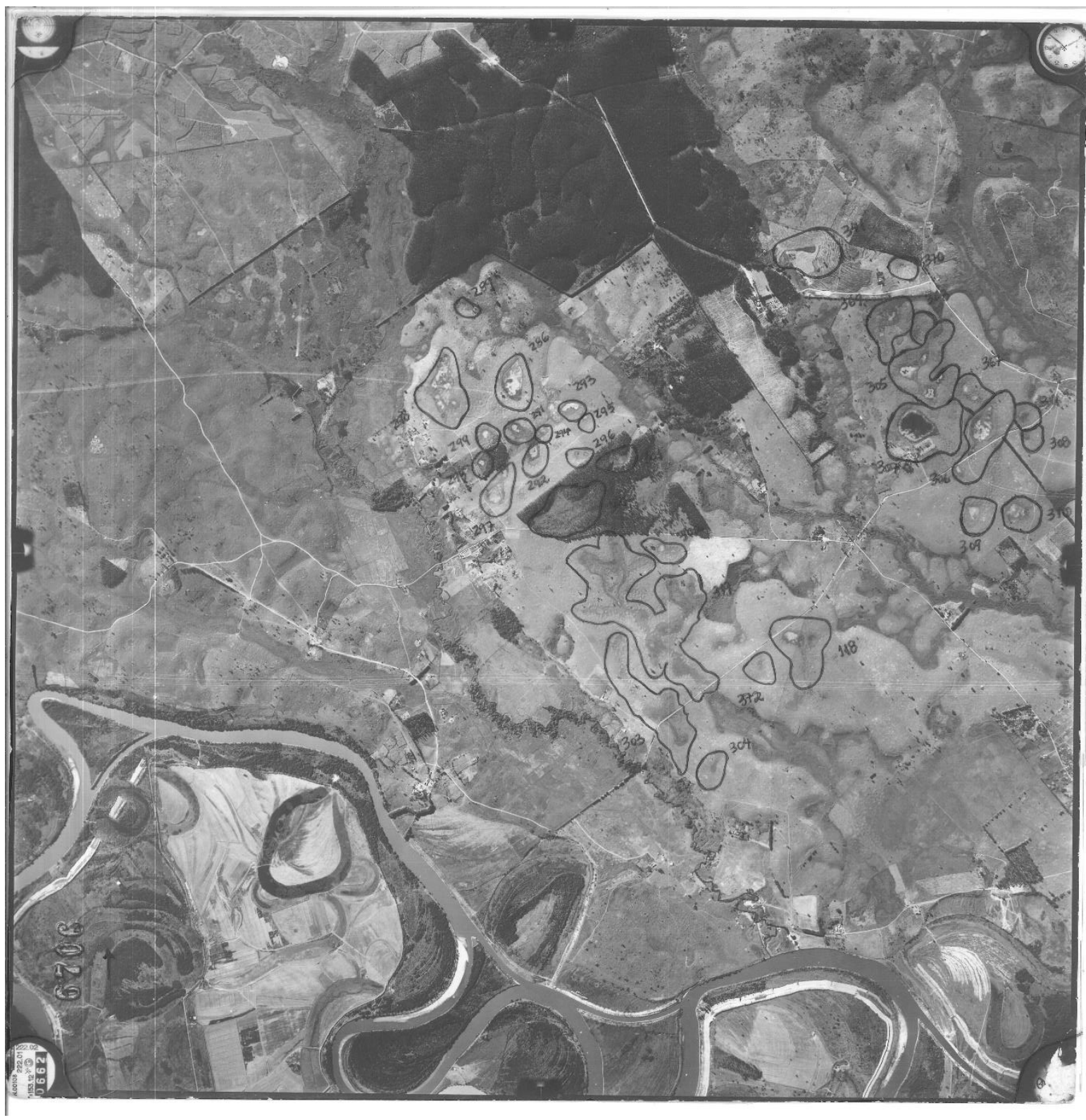

Fonte: Secretaria de Agricultura do Estado de São Paulo - Instituto Agronômico. (1962). Escala aproximada da foto: 1.25.000. Aerofoto Natividade Ltda. Foto n. 6706. Org. Leal (2017). 
No total, somaram 18 fotografias aéreas $(6522,6525,6568,6570,6577$, 6582, 6586, 6633, 6635, 6637, 6639, 6652, 6706, 6707, 6709, 6715, 6803 e 6806) e 207 depressões. Após, por meio do uso do SIG "Arcgis", as mesmas foram georreferenciadas, e em seguida, desenhou-se polígonos sobre as áreas que representam as depressões no conjunto foto/layer. Por fim, suas imagens foram sobrepostas no mapa preliminar de potencial arqueológico, junto com o layer das áreas altas em relação ao rio Paraíba e com a localização das colinas ou morros. Assim, foi possível conferir a disposição das três formas representadas no mapa 1 (vide anexo).

À tabela de atributos gerada (vide tabela 4) a partir dos desenhos das depressões, foram adicionados dois campos: comprimento e área. A partir do cálculo desses dois parâmetros, foi possível classificar as depressões em três categorias: grandes, médias e pequenas. A distância delas em relação ao rio Paraíba também foi aferida por meio da criação de um "Buffer", que produziu um limite do canal principal até 100 metros de cada margem. Poderiam ser criadas outras classes de distância, porém, nota-se pelo mapa que a maior parte das depressões está bem mais longe que 200 ou 300 metros do rio.

Tabela 4 - Localização e dimensão das depressões

\begin{tabular}{c|c|c|c|c}
\hline Identificação & Longitude & Latitude & Comprimento $(\mathbf{m})$ & Área $\left(\mathbf{m}^{2}\right)$ \\
\hline D1 & 449201 & 7462598 & 2700,02 & 521408,63 \\
\hline D108 & 460445 & 7468237 & 2723,86 & 163411,57 \\
\hline D109 & 460704 & 7468397 & 570,23 & 23393,86 \\
\hline D110 & 463581,52 & 7468599,32 & 442,77 & 14903,70 \\
\hline D114 & 465373 & 7468819 & 344,22 & 7527,74 \\
\hline D115 & 465634 & 7469029 & 5028,32 & 512479,13 \\
\hline D117 & 464828 & 7469459 & 2979,70 & 263285,67 \\
\hline D118 & 472143 & 7475086 & 1439,99 & 124269,14 \\
\hline D12 & 450786 & 7459469 & 3189,52 & 334881,42 \\
\hline D123 & 459753 & 7463591 & 1251,68 & 109719,22 \\
\hline D124 & 459588 & 7463790 & 1090,85 & 90834,24 \\
\hline D125 & 459717 & 7464304 & 1442,58 & 131486,02 \\
\hline D126 & 459353 & 7463283 & 1751,74 & 181775,82 \\
\hline D127 & 459266 & 7462606 & 1593,96 & 162708,24 \\
\hline D128 & 456065 & 7462820 & 1022,39 & 73562,40 \\
\hline D129 & 456605 & 7462008 & 2915,24 & 567474,95 \\
\hline D13 & 450089 & 7459325 & 1702,08 & 156866,35 \\
\hline D144 & 452481 & 7461612 & 870,54 & 58074,71 \\
\hline D145 & 454504 & 7460006 & 1278,44 & 111955,87 \\
\hline D147 & 454308 & 7460907 & 1347,73 & 126951,42 \\
\hline D148 & 455013 & 7462513 & 1573,10 & 150777,63 \\
\hline & & & &
\end{tabular}




\begin{tabular}{|c|c|c|c|c|}
\hline D149 & 455354 & 7460350 & 1363,77 & 126203,21 \\
\hline D15 & 454182 & 7458662 & 396,06 & 11866,62 \\
\hline D151 & 456104 & 7463550 & 1163,22 & 72951,25 \\
\hline D152 & 456179 & 7464493 & 1325,70 & 121997,05 \\
\hline D153 & 453502 & 7464148 & 839,88 & 54825,10 \\
\hline D154 & 453029 & 7464193 & 1213,01 & 114870,58 \\
\hline D155 & 457947 & 7462746 & 1324,35 & 130306,46 \\
\hline D156 & 457758 & 7463475 & 1346,75 & 135535,67 \\
\hline D157 & 455142 & 7464720 & 1907,25 & 192330,69 \\
\hline D158 & 456464 & 7463912 & 1729,64 & 154926,42 \\
\hline D16 & 455986 & 7460094 & 2689,33 & 391675,85 \\
\hline D161 & 458195 & 7461385 & 1409,82 & 113158,83 \\
\hline D162 & 455733 & 7463590 & 1217,48 & 80618,44 \\
\hline D164 & 458677 & 7461138 & 1981,15 & 210031,78 \\
\hline D165 & 458832 & 7463583 & 853,56 & 56410,14 \\
\hline D166 & 460170 & 7464621 & 987,21 & 67264,50 \\
\hline D167 & 452724 & 7460103 & 1286,78 & 123405,89 \\
\hline D168 & 452743 & 7459739 & 1163,89 & 86813,60 \\
\hline D175 & 451612 & 7462309 & 730,65 & 39626,12 \\
\hline D179 & 453753 & 7459658 & 1140,30 & 75409,68 \\
\hline D18 & 456188 & 7459948 & 1173,64 & 85462,92 \\
\hline D180 & 453894 & 7458761 & 1227,66 & 103662,84 \\
\hline D182 & 458422 & 7460519 & 774,05 & 45786,87 \\
\hline D183 & 458456 & 7461384 & 977,43 & 58122,88 \\
\hline D184 & 461024 & 7461086 & 3075,45 & 445510,28 \\
\hline D186 & 461643 & 7468761 & 544,30 & 21382,35 \\
\hline D187 & 463396 & 7468651 & 1258,21 & 94702,25 \\
\hline D188 & 463203 & 7467559 & 1373,96 & 103900,44 \\
\hline D189 & 462930 & 7466937 & 572,78 & 23403,42 \\
\hline D190 & 462902 & 7467348 & 1285,65 & 80281,16 \\
\hline D191 & 462393 & 7468223 & 856,48 & 43854,67 \\
\hline D193 & 463339 & 7467699 & 401,06 & 11786,82 \\
\hline D194 & 463903 & 7468916 & 852,44 & 45383,16 \\
\hline D195 & 464004 & 7468717 & 688,67 & 34379,54 \\
\hline D197 & 465127 & 7468283 & 864,36 & 51803,42 \\
\hline D198 & 465852 & 7468323 & 3827,14 & 330326,83 \\
\hline D199 & 465414 & 7467956 & 1607,88 & 126228,83 \\
\hline D2 & 449337 & 7461750 & 1581,78 & 160002,56 \\
\hline D202 & 466150 & 7465975 & 753,34 & 42505,12 \\
\hline D203 & 466418 & 7466105 & 2245,65 & 227161,49 \\
\hline D205 & 450731 & 7463183 & 1532,09 & 176942,56 \\
\hline D206 & 450899 & 7463319 & 1018,60 & 67577,00 \\
\hline D207 & 453879 & 7464726 & 1461,29 & 119862,05 \\
\hline D209 & 453483 & 7463187 & 891,62 & 53988,26 \\
\hline D211 & 449716 & 7463825 & 850,97 & 46415,86 \\
\hline $\mathrm{D} 212$ & 450241 & 7461675 & 724,74 & 40858,20 \\
\hline D213 & 449902 & 7460530 & 1587,54 & 167532,87 \\
\hline D214 & 449679 & 7460715 & 1941,04 & 242483,97 \\
\hline D219 & 449514 & 7470526 & 453,91 & 14724,49 \\
\hline D220 & 449285 & 7470786 & 379,84 & 10593,66 \\
\hline D221 & 449238 & 7471032 & 551,62 & 19475,85 \\
\hline D222 & 450185 & 7469301 & 698,37 & 26147,99 \\
\hline
\end{tabular}




\begin{tabular}{|c|c|c|c|c|}
\hline D225 & 467843 & 7465801 & 1034,32 & 65443,38 \\
\hline D226 & 467772 & 7465652 & 2221,83 & 261188,33 \\
\hline D228 & 467371 & 7467912 & 475,47 & 17265,66 \\
\hline D231 & 460865 & 7468173 & 1060,38 & 64097,98 \\
\hline D232 & 463123 & 7467209 & 679,86 & 31119,01 \\
\hline D233 & 463975 & 7468525 & 781,67 & 40614,06 \\
\hline D234 & 466568 & 7467887 & 591,31 & 25530,69 \\
\hline D237 & 472899 & 7469898 & 381,38 & 10811,51 \\
\hline D238 & 459276 & 7464927 & 1300,14 & 123517,13 \\
\hline D239 & 453629 & 7464671 & 938,56 & 63611,52 \\
\hline D240 & 450688 & 7459103 & 1077,06 & 84949,77 \\
\hline D241 & 454952 & 7475780 & 494,31 & 17752,30 \\
\hline D243 & 461922 & 7474359 & 813,85 & 46926,62 \\
\hline $\mathrm{D} 25$ & 457196 & 7458176 & 968,14 & 70947,72 \\
\hline D250 & 464384 & 7477027 & 945,07 & 62889,31 \\
\hline D251 & 464187 & 7477132 & 1410,38 & 122041,81 \\
\hline D253 & 464460 & 7478031 & 987,68 & 60371,98 \\
\hline D257 & 463643 & 7478243 & 1376,45 & 109585,79 \\
\hline D258 & 466515 & 7478211 & 770,08 & 35775,16 \\
\hline D259 & 466727 & 7476928 & 1493,59 & 104823,80 \\
\hline D260 & 467102 & 7475181 & 761,28 & 40340,58 \\
\hline D261 & 465448 & 7478149 & 1006,56 & 59269,83 \\
\hline D263 & 466095 & 7476129 & 413,96 & 12263,13 \\
\hline D265 & 466213 & 7474958 & 545,68 & 21843,63 \\
\hline D268 & 466617 & 7476272 & 605,45 & 27134,63 \\
\hline D270 & 466868 & 7475939 & 1333,98 & 72564,16 \\
\hline D272 & 467505 & 7474889 & 755,94 & 38033,23 \\
\hline D273 & 467964 & 7477688 & 522,74 & 20677,96 \\
\hline D274 & 467987 & 7477564 & 384,57 & 11188,28 \\
\hline D275 & 468163 & 7477488 & 834,78 & 42094,34 \\
\hline D276 & 468349 & 7477093 & 517,16 & 20104,63 \\
\hline D279 & 468325 & 7475453 & 314,68 & 7517,97 \\
\hline D280 & 467735 & 7474760 & 883,03 & 56400,20 \\
\hline D281 & 467964 & 7474732 & 478,81 & 17177,45 \\
\hline D282 & 467892 & 7474909 & 519,30 & 19332,48 \\
\hline D283 & 468331 & 7474737 & 1029,34 & 56375,56 \\
\hline D284 & 468721 & 7474656 & 1151,41 & 55282,37 \\
\hline D285 & 468194 & 7475489 & 603,79 & 27343,49 \\
\hline D286 & 470199 & 7476617 & 975,31 & 65824,50 \\
\hline D289 & 469860 & 7477091 & 459,39 & 14442,23 \\
\hline D290 & 469769 & 7476688 & 1341,84 & 109536,51 \\
\hline D291 & 470221 & 7476334 & 580,41 & 25224,06 \\
\hline D292 & 470360 & 7476230 & 614,00 & 26830,25 \\
\hline D293 & 470551 & 7476470 & 503,29 & 18771,46 \\
\hline D294 & 470382 & 7476341 & 381,76 & 10429,64 \\
\hline D295 & 470671 & 7476424 & 390,70 & 10402,10 \\
\hline D296 & 470643 & 7476195 & 502,24 & 17652,51 \\
\hline D297 & 470106 & 7475908 & 879,72 & 49007,71 \\
\hline D298 & 470031 & 7476124 & 502,20 & 18810,14 \\
\hline D299 & 470046 & 7476303 & 523,25 & 20678,80 \\
\hline D3 & 450847 & 7462616 & 1716,44 & 207961,89 \\
\hline D30 & 450159 & 7458742 & 1099,38 & 89903,15 \\
\hline
\end{tabular}




\begin{tabular}{|c|c|c|c|c|}
\hline D300 & 470513 & 7475794 & 1401,71 & 120311,62 \\
\hline D301 & 470878 & 7476185 & 720,49 & 33490,21 \\
\hline D302 & 471175 & 7475618 & 743,79 & 30728,11 \\
\hline D303 & 471239 & 7474599 & 2426,54 & 175561,09 \\
\hline D304 & 471552 & 7474286 & 699,30 & 35676,59 \\
\hline D305 & 472703 & 7476787 & 1997,26 & 142785,67 \\
\hline D306 & 473205 & 7476453 & 1581,70 & 123568,72 \\
\hline D307 & 472728 & 7476440 & 1570,81 & 153222,93 \\
\hline D308 & 473535 & 7476449 & 534,59 & 19502,73 \\
\hline D309 & 473149 & 7475931 & 776,49 & 43900,18 \\
\hline D310 & 473410 & 7475940 & 778,37 & 46180,65 \\
\hline D311 & 473468 & 7476527 & 575,24 & 24528,50 \\
\hline D319 & 470880 & 7475470 & 4862,86 & 460985,89 \\
\hline D324 & 463188 & 7480277 & 830,07 & 49908,25 \\
\hline D326 & 465737 & 7478577 & 523,78 & 18485,70 \\
\hline D328 & 465720 & 7478307 & 580,39 & 24175,68 \\
\hline D329 & 465806 & 7478185 & 456,81 & 15185,96 \\
\hline D33 & 449782 & 7457302 & 2010,54 & 197663,93 \\
\hline D330 & 465575 & 7478212 & 412,85 & 12744,20 \\
\hline D332 & 465863 & 7476904 & 847,58 & 36851,13 \\
\hline D334 & 469474 & 7480866 & 753,14 & 40464,42 \\
\hline D335 & 469417 & 7479341 & 469,94 & 16074,18 \\
\hline D338 & 469327 & 7481923 & 551,05 & 22416,35 \\
\hline D339 & 469543 & 7481883 & 545,95 & 22674,50 \\
\hline D34 & 451248 & 7458369 & 1032,26 & 77466,13 \\
\hline D340 & 469681 & 7481911 & 501,42 & 17243,89 \\
\hline D341 & 472038 & 7477553 & 1205,32 & 98682,99 \\
\hline D344 & 464328 & 7482749 & 345,00 & 8894,96 \\
\hline D345 & 464079 & 7482626 & 345,46 & 9128,60 \\
\hline D349 & 468567 & 7479690 & 427,64 & 13841,31 \\
\hline D352 & 470742 & 7483537 & 522,70 & 18061,19 \\
\hline D353 & 468604 & 7466282 & 565,66 & 23834,93 \\
\hline D354 & 468741 & 7466392 & 499,43 & 18145,20 \\
\hline D355 & 463984 & 7463745 & 905,66 & 58555,36 \\
\hline D356 & 465025,39 & 7465021,18 & 3193,00 & 749374,25 \\
\hline D358 & 453547 & 7457167 & 1066,54 & 77854,24 \\
\hline D359 & 453599 & 7456871 & 839,55 & 51057,31 \\
\hline D360 & 455177 & 7457554 & 881,92 & 58532,61 \\
\hline D361 & 466418 & 7465650 & 544,20 & 21780,30 \\
\hline D362 & 465832 & 7469561 & 535,03 & 20010,82 \\
\hline D364 & 459794 & 7462803 & 408,30 & 12360,16 \\
\hline D365 & 459489 & 7464289 & 724,79 & 35891,89 \\
\hline D366 & 463776 & 7468836 & 609,41 & 24166,71 \\
\hline D367 & 473110 & 7476686 & 800,22 & 41964,43 \\
\hline D368 & 472745 & 7477053 & 616,90 & 24236,16 \\
\hline D369 & 472594 & 7477134 & 1199,06 & 78792,72 \\
\hline D370 & 472679 & 7477430 & 565,03 & 23577,56 \\
\hline D371 & 465313 & 7468625 & 904,18 & 52846,49 \\
\hline D372 & 471821 & 7474934 & 653,56 & 30632,49 \\
\hline D373 & 468232 & 7474827 & 599,63 & 21176,12 \\
\hline D374 & 467204 & 7474987 & 596,13 & 19695,38 \\
\hline D375 & 464127 & 7478577 & 488,10 & 18402,81 \\
\hline
\end{tabular}




\begin{tabular}{c|c|c|c|c} 
D376 & 468886 & 7466173 & 522,91 & 20609,36 \\
\hline D377 & 451368 & 7462670 & 575,10 & 21924,57 \\
\hline D378 & 457979 & 7466246 & 1162,54 & 74831,44 \\
\hline D379 & 458424 & 7466351 & 771,64 & 43255,20 \\
\hline D380 & 458368 & 7466536 & 624,86 & 25844,84 \\
\hline D381 & 458509 & 7466647 & 1179,02 & 104237,19 \\
\hline D382 & 458841 & 7466162 & 2867,03 & 339522,41 \\
\hline D44 & 453679 & 7458488 & 1393,72 & 119278,21 \\
\hline D52 & 457138 & 7457432 & 833,48 & 52258,17 \\
\hline D58 & 451529 & 7457696 & 609,11 & 26267,69 \\
\hline D65 & 459305 & 7464284 & 675,76 & 34657,02 \\
\hline D66 & 458927 & 7464167 & 963,51 & 68800,54 \\
\hline D67 & 459162 & 7464133 & 1182,27 & 86630,25 \\
\hline D74 & 461276 & 7465955 & 1264,32 & 98635,63 \\
\hline D75 & 460853 & 7465620 & 1253,78 & 87704,03 \\
\hline D76 & 461310 & 7465666 & 458,24 & 15036,12 \\
\hline D77 & 461224 & 7464945 & 2072,53 & 322786,93 \\
\hline D78 & 461675 & 7465196 & 861,00 & 48669,45 \\
\hline D79 & 461878 & 7465145 & 789,98 & 41470,60 \\
\hline D80 & 461935 & 7464845 & 901,80 & 53194,41 \\
\hline D81 & 462949 & 7464632 & 1352,19 & 104923,34 \\
\hline D83 & 462603 & 7464491 & 663,56 & 31074,91 \\
\hline D85 & 463310 & 7464682 & 1876,47 & 259591,95 \\
\hline D87 & 464413 & 7466019 & 1493,74 & 162385,34 \\
\hline D88 & 464392 & 7465251 & 1678,27 & 210615,03 \\
\hline D89 & 465888 & 7467843 & 3045,08 & 359277,71 \\
\hline D90 & 466202 & 7467522 & 1699,60 & 140635,78 \\
\hline D91 & 466342 & 7467021 & 989,85 & 67095,93 \\
\hline D92 & 466429 & 7466758 & 901,48 & 57834,32 \\
\hline D94 & 468692 & 7466057 & 830,94 & 40611,64 \\
\hline
\end{tabular}

Fonte: Leal (2017).

O mapa preliminar de áreas de potencial arqueológico foi gerado sobre a base digitalizada da carta topográfica de Pindamonhangaba, na escala 1:50.000, georreferenciada.

Sobre essa plataforma ainda foram elaborados a carta hipsométrica e os perfis topográficos da área de estudo. Vide anexos. A partir desses produtos cartográficos, foi possível identificar as áreas não inundáveis, que se supõe serem os terraços mais antigos do rio Paraíba e que foram aferidos com base nas curvas de nível que os delimitam. Nessas áreas se localiza a maior parte das depressões e a linha de raciocínio aqui adotada, sugere que, na planície de inundação do Rio Paraíba do Sul, a própria dinâmica fluvial alterou bastante as feições morfológicas da área, de modo que, se houve algum material arqueológico, ele não está mais lá. 
Anterior a esse procedimento, foram testadas duas técnicas de elaboração de perfis topográficos: a manual sobre papel milimetrado e por meio da ferramenta mostrar caminho, do Google Earth. Após traçar uma linha sobre a imagem, clica-se com o botão direito do mouse sobre ela e escolhe-se a opção "mostrar perfil de elevação".

O mapa 1 (em anexo) mostra as depressões diferenciadas por classes de tamanho. Considerou-se para esse trabalho os seguintes parâmetros: de 75.000 a 90.000 metros de área = pequenas; de 90.000 a 260.000 metros = médias e de 260.000 a 750.000 metros $=$ grandes.

\subsection{TESTANDO UMA HIPÓTESE}

A opção pela apresentação de um "modelo" de localização de sítios e não de um "mapa" somente, justifica-se pela percepção de que não se vai a campo em busca de locais delimitados denominados "sítios arqueológicos", mas sim de "material arqueológico", que pode estar dentro ou fora desta "estrutura".

Porém, ao alimentar tal expectativa convém lembrar a ressalva feita por Goldberg (2008) à "New Archaeology" dos anos 1970, sobre a pressão sofrida pelos seguidores dessa corrente teórica arqueológica para que se chegue a um modelo, ao final da pesquisa, como prova da "cientificidade" de seu trabalho. Este autor também chama a atenção para a criação de expectativas de resultados no início do estudo como uma forma de negação da possibilidade de uma hipótese nula "[...] Where is your null hypothesis?" (p.27).

Ademais, a discussão do tópico sobre fundamentos da pesquisa científica demonstra que a ciência se preocupa com a explanação dos fenômenos e a hipótese seria um meio para obtê-la.

[...] Uma hipótese é uma explanação proposta para um conjunto específico e coisas ou eventos; é, portanto, o produto da aplicação da teoria e do método, por meio da técnica, a um determinado conjunto de dados. [..] Hipóteses não são provadas; antes, os limites de sua utilidade em termos de predição ou controle são estabelecidos. Elas são substituídas por hipóteses cuja utilidade é maior. (DUNNELL, 2007, p. 59-60).

Mesmo no caso da constatação de que a hipótese aqui levantada - a existência de sítios pré-coloniais em Pindamonhangaba - não pudesse ser verificada, 
o valor da pesquisa ainda estaria assegurado se comprovada a correta aplicação do método - hipotético dedutivo - apoiado pela estrutura teórica. Essa importância do procedimento científico é igualmente ressaltada por Eco (1983, p.24)

O bom de um procedimento científico é que ele nunca faz os outros perderem tempo: até mesmo trabalhar na esteira de uma hipótese científica para depois descobrir que ela deve ser refutada significa ter feito algo positivo sob o impulso de uma proposta anterior. [...].

Felizmente, a hipótese dessa pesquisa pôde ser verificada por meio de duas etapas de controle de campo. Após a confecção da primeira versão do mapa de potencial arqueológico, no formato “.dgn”, do mapa hipsométrico e dos perfis topográficos (vide anexos I, II e III), seguiu-se uma análise das feições do relevo quanto a sua distribuição espacial. Tal parâmetro foi usado para nortear a escolha de quatro áreas para realização de prospecção arqueológica: duas depressões, uma porção do terraço do rio Paraíba e uma área elevada, de morro.

O método de prospecção adotado foi baseado em um programa específico para encontrar sítios Paleoíndios, a céu aberto, na Região de Lagoa Santa, Minas Gerais, e que resultou no encontro de dois sítios às margens da Lagoa do Sumidouro: Sítio Sumidouro e Sítio Coqueirinho, por meio de prospecções intensivas de subsuperfície por trado motorizado, a profundidades de três metros em poucos minutos, cobrindo uma área de $120 \mathrm{~m} \times 120 \mathrm{~m}^{2}$ com uma malha de furo equidistantes 15 metros. (ARAUJO et al, 2013). Método semelhante foi empregado em Ipeúna, onde foi localizado o Sítio Lagoa do Camargo, área na qual também foram considerados os processos de erosão e de deposição que podem influenciar na distribuição dos artefatos no solo, ou seja, o quanto eles podem estar enterrados. Para a prospecção neste local, seguiu-se uma malha triangular de furos de 30 metros de distância, método que otimiza a cobertura da área, se comparada a malhas mais tradicionais que seguem linhas paralelas. (ARAUJO et al 2017).

Embora não tenhamos utilizado nos trabalhos de campo de nossa pesquisa, o trado motorizado, mas sim o trado manual, de copo caneco, a princípio e, posteriormente, o de copo holandês, seguimos a ideia da malha triangular (sondagens sistemáticas) a profundidades maiores que 150 centímetros, a cada 30 metros, por dois motivos principais: 1 - em ambientes tropicais, os solos são mais espessos e nas áreas elencadas para prospecção (encosta de uma área de colina alongada e margem de depressões) as chances de ocorrem eventos que pudessem resultar em 
soterramento de artefatos (movimentos de massa e coluvionamento) eram maiores; 2 - a malha triangular, além de cobrir uma área maior que a tradicional (linhas paralelas), pode ser feita por meio da marcação dos pontos com cordas, evitando-se o uso do GPS e do erro de sua precisão.

\subsubsection{Atividades da primeira etapa de campo}

Nos dias 23 e 25 de janeiro de 2017, realizaram-se as primeiras atividades de prospecção arqueológica na área de uma das colinas, apontadas pelo mapa, como de maior potencial arqueológico. A mesma localiza-se dentro de uma propriedade privada, no Bairro do Pinga, no município de Pindamonhangaba. Foi realizado caminhamento sobre a área e os pontos de maior relevância, tais como ocorrências de quartzos em superfície (vide foto 1), um abrigo (vide foto 2) e um platô na vertente foram fotografados. Um dos proprietários da área, Felipe Bueno, acompanhou a equipe de prospecção. De acordo com ele, a fazenda pertence à família Bueno desde a década de 1970. No passado, as terras foram utilizadas para o cultivo de café, e, atualmente, são usadas para o pasto de gado leiteiro.

As amostras de quartzo não foram coletadas nesse momento, mas sua localização foi sinalizada para posterior recolhimento. O objetivo dessa visita a área de colina foi o reconhecimento do terreno para subsidiar o plano de prospecção. No topo da vertente, encontra-se uma formação rochosa conhecida na região por Falésia Paraíso. 
Foto 1 - Quartzo sobre bloco de rocha

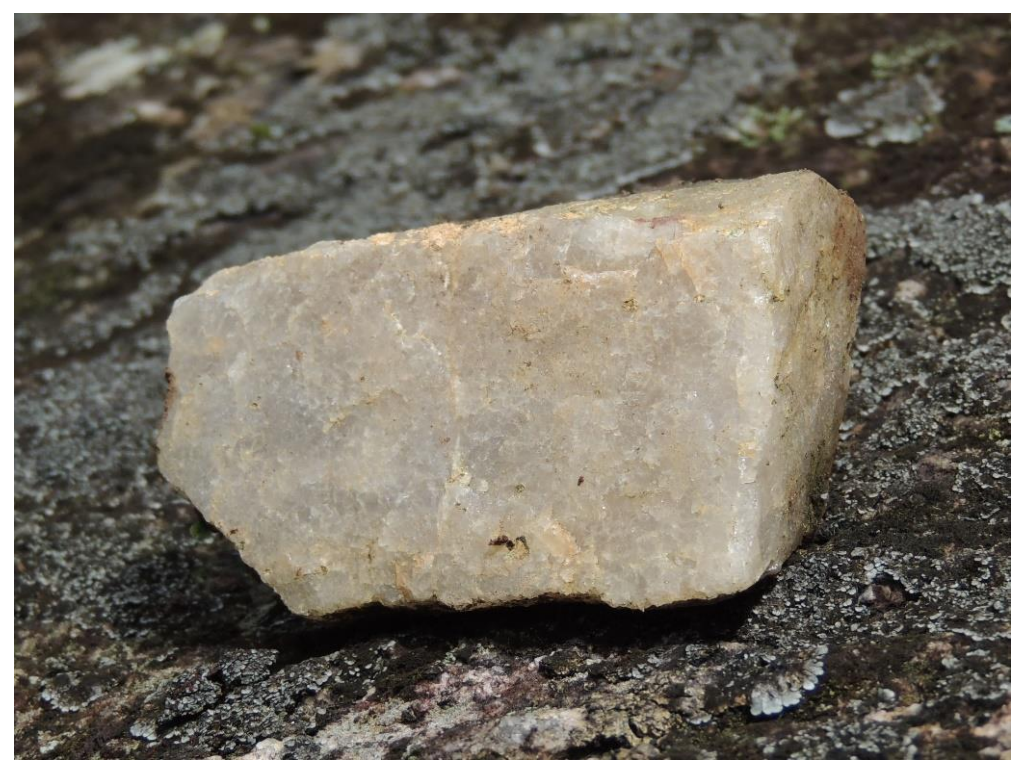

Fonte: Leal (2017).

\section{Foto 2 - Abrigo rochoso}

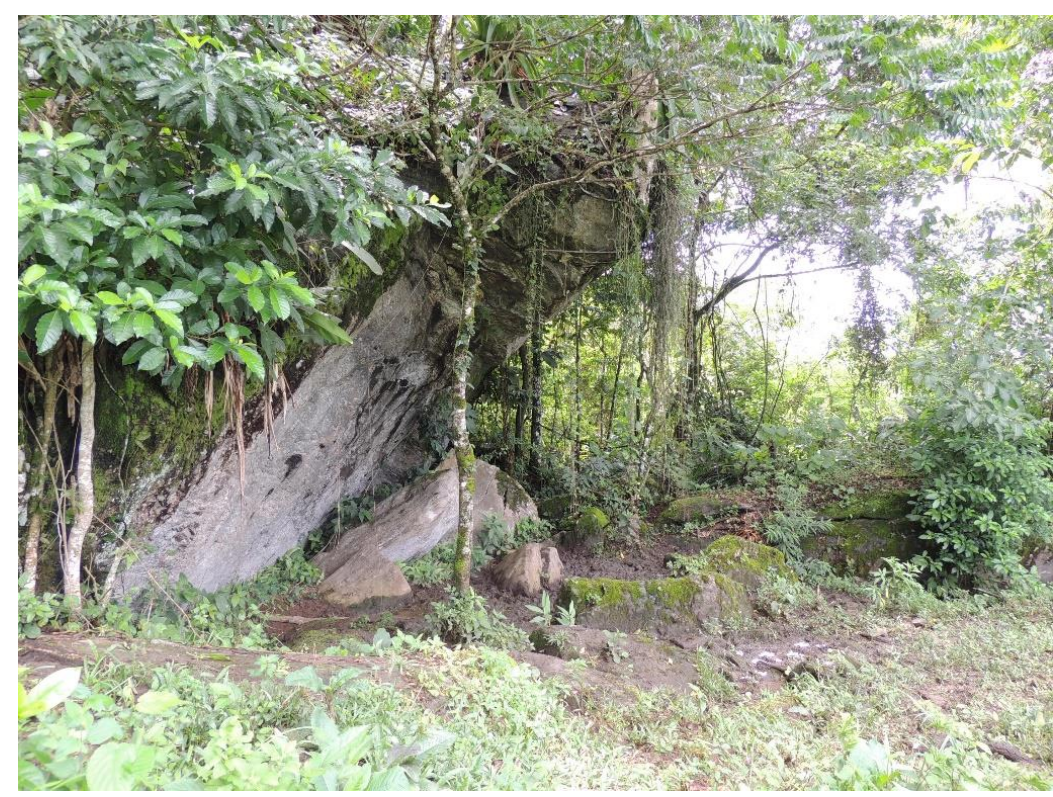

Fonte: Leal (2017).

Em uma de suas faces, foi notada a ocorrência do afloramento de minerais de quartzo (vide foto 3), a cerca de 30 metros da base do paredão. 
Foto 3 - Afloramento de quartzo em paredão da Falésia Paraíso

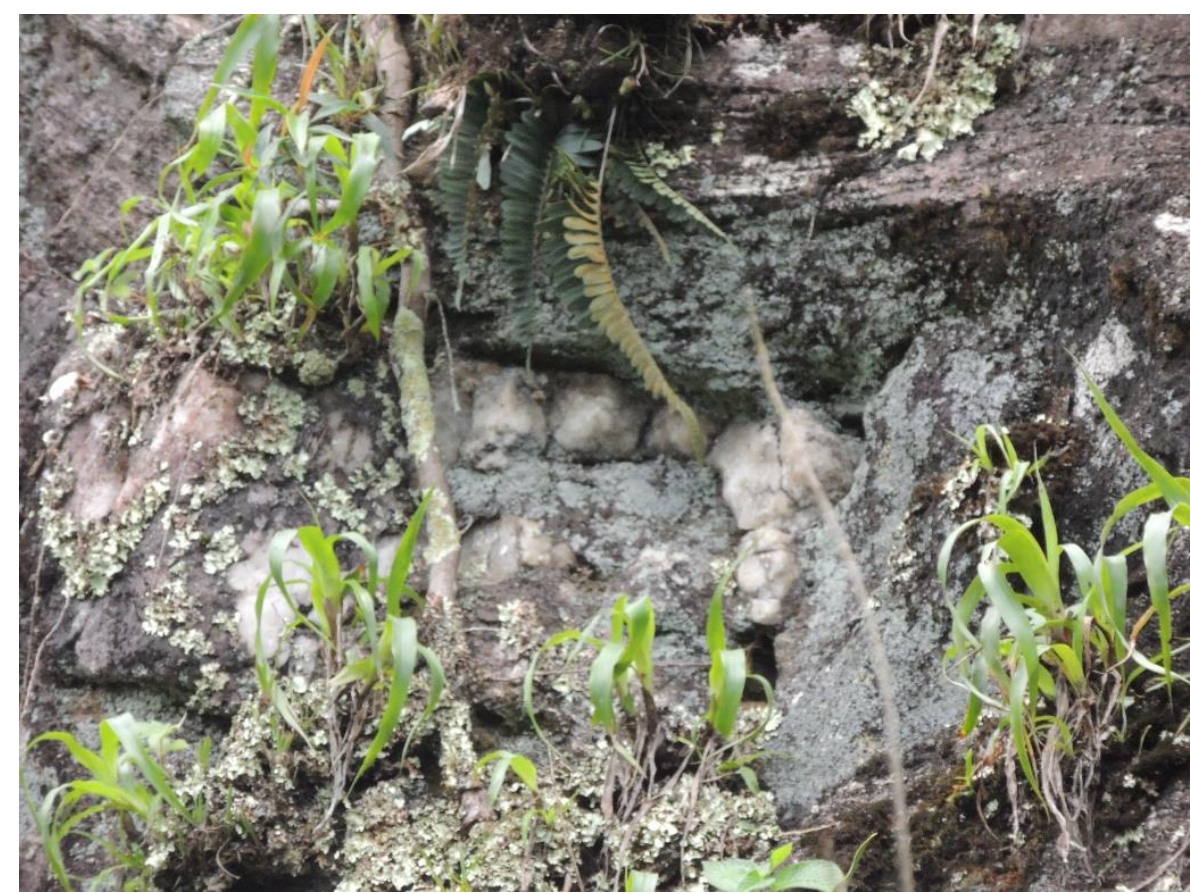

Fonte: Leal (2017).

A localização das sondagens obedeceu ao método da triangulação do terreno, de modo que a partir do primeiro furo, mediu-se 30 metros e realizou-se a segunda tradagem. $O$ terceiro ponto foi calculado com base nas posições dos dois primeiros, fechando um triângulo retângulo de 30 metros. Os demais furos foram determinados partindo-se de um desses vértices do triângulo inicial.

A primeira etapa de controle de campo foi realizada entre os dias 29/01/17 e 03/02/17 com o intuito de testar a hipótese dessa pesquisa, bem como de finalizar o mapa de potencial arqueológico. Foi realizada por uma equipe de oito pessoas, que se dividiu em dois grupos. Ambos os grupos, o primeiro, constituído de 4 pessoas e o segundo, de cinco, permaneceram 3 dias em campo e se revezaram nas tarefas de prospecção.

A prospecção de subsuperfície foi realizada em um morro (colina 12) e na depressão D1 (vide foto 4) com o uso do trado manual. 
Foto 4 - Depressão D1

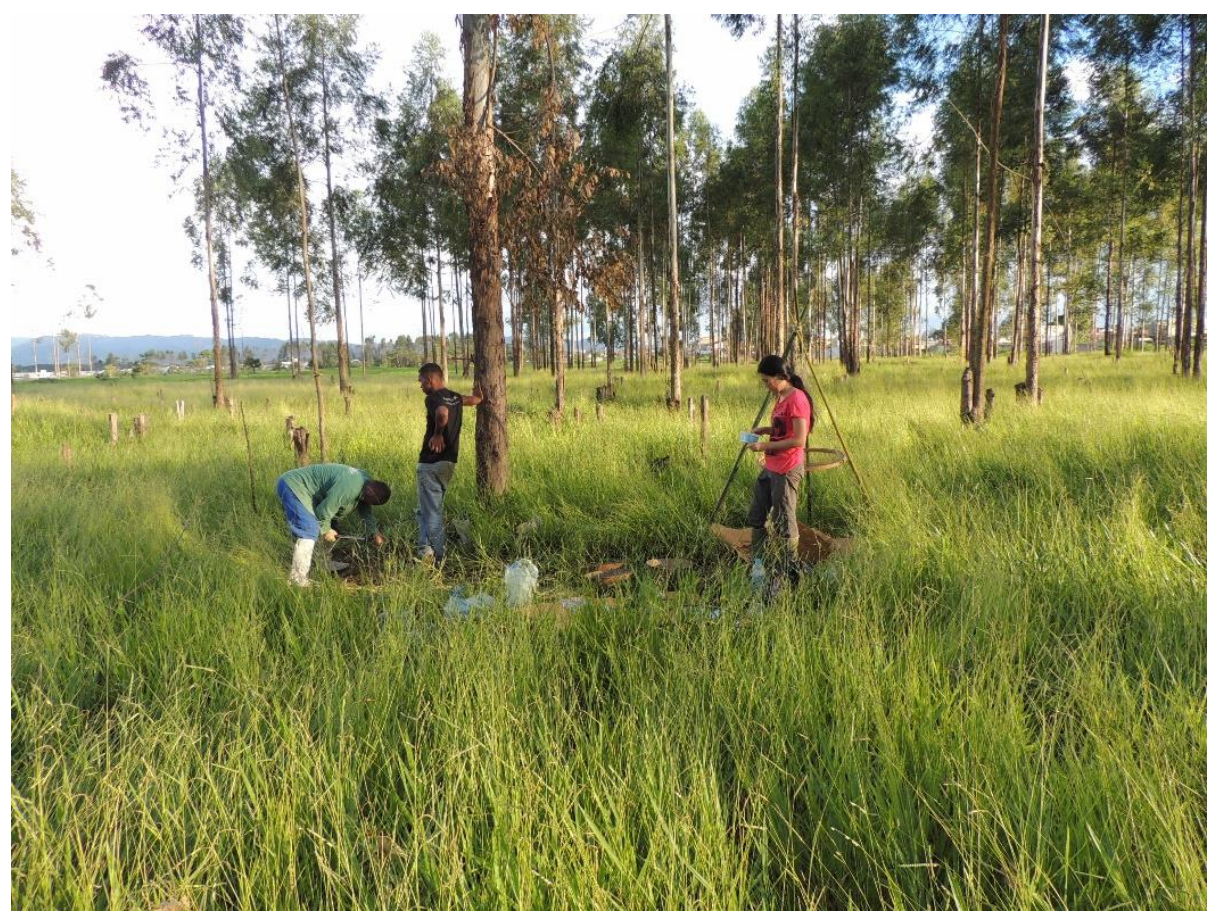

Fonte: Spengler (2017).

No primeiro furo (P1), utilizou-se o trado com copo do tipo caneco, acoplado a extensões de $40 \mathrm{~cm}$, até a profundidade de 147 centímetros e, a partir desse nível, optou-se pelo uso do trado com copo do tipo holandês. A mudança do tipo de copo se deveu a maior facilidade de perfuração do solo, propiciado pelo copo tipo holandês. Todas as outras sondagens, a partir dessa, foram feitas com o copo do tipo holandês.

Amostras de solo de todos os níveis foram coletadas para aferir a cor, posteriormente, bem como o material lítico supostamente com potencial arqueológico. Para peneirar o material (vide foto 5), foram usadas duas peneiras de malha de $4 \mathrm{~mm}$, sustentadas por tripés de bambus. 
Foto 5 - Peneiramento do sedimento escavado.

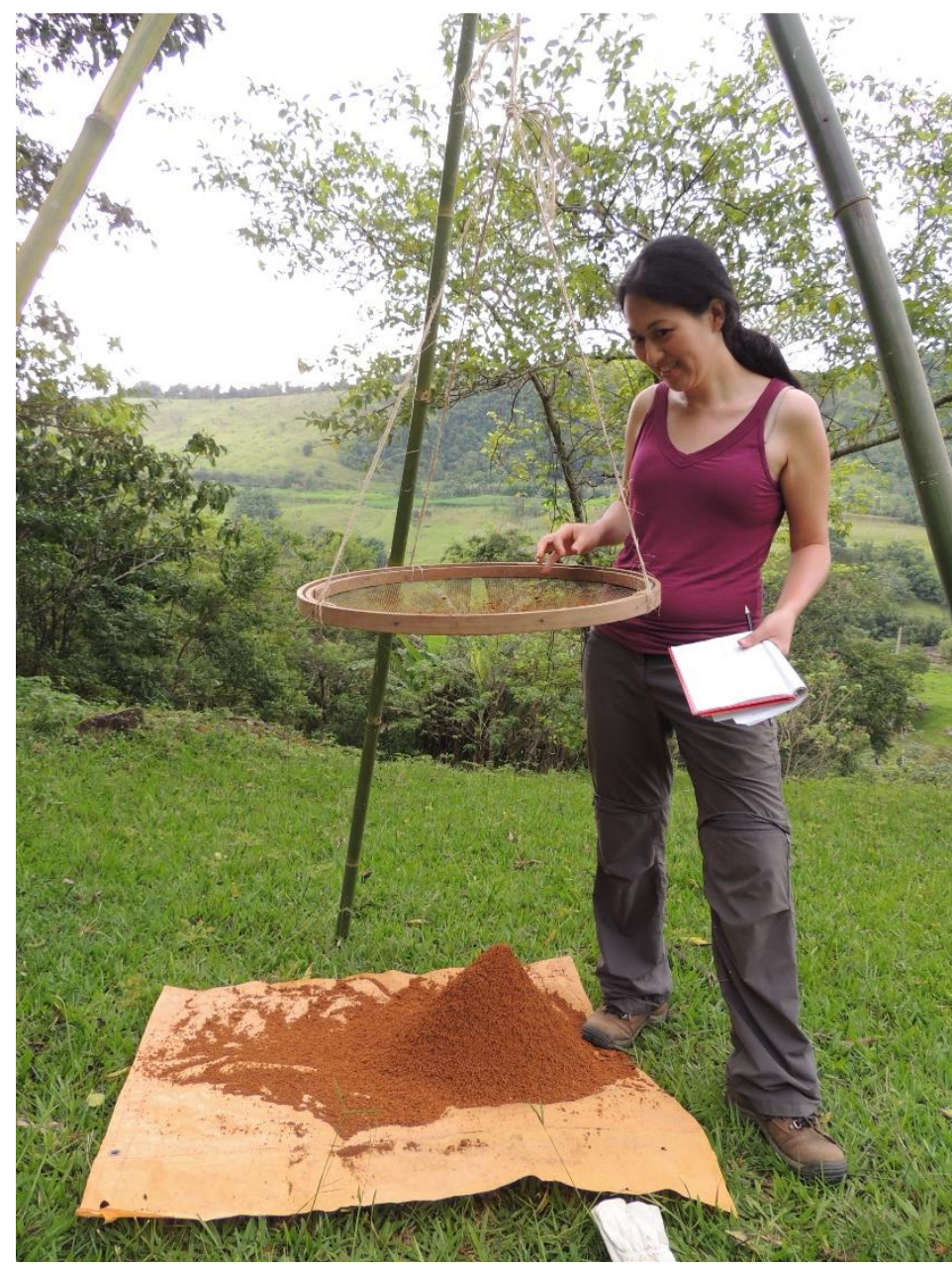

Fonte: Spengler (2017).

Foram realizadas 18 sondagens na área de colina e 6 sondagens na área da depressão, totalizando vinte e seis furos, dos quais, em seis o material encontrado e coletado foi confirmado como de potencial arqueológico, após análise em laboratório.

Um fragmento de cerâmica também foi coletado a três metros de profundidade, na sondagem P26, na área da D1, depressão conhecida como Lagoa do Paturi.

\subsubsection{Atividades da segunda etapa de campo}

A segunda etapa de controle de campo, realizada em Pindamonhangaba, entre os dias 21 e 27 de março de 2017, teve por objetivo ampliar a área amostral de prospecção e abrir uma quadra $1 \mathrm{~m} \times 1 \mathrm{~m}$. A opção pela decapagem nesse ponto de 
sondagem (P1), efetuado na primeira campanha de campo, justificou-se pela ocorrência de material potencialmente arqueológico em dois níveis de profundidade distintos.

Além da abertura de novas sondagens com trado manual, foram realizadas atividades de prospecção de superfície (caminhamento) no entorno da área de colina e em áreas de abrigo, bem como o registro fotográfico.

\subsubsection{Sondagens por trado}

Foram realizadas três sondagens na área de depressão D129, dentro de propriedade sob concessão da prefeitura municipal. Vide foto 6.

\section{Foto 6 - Depressão D129}

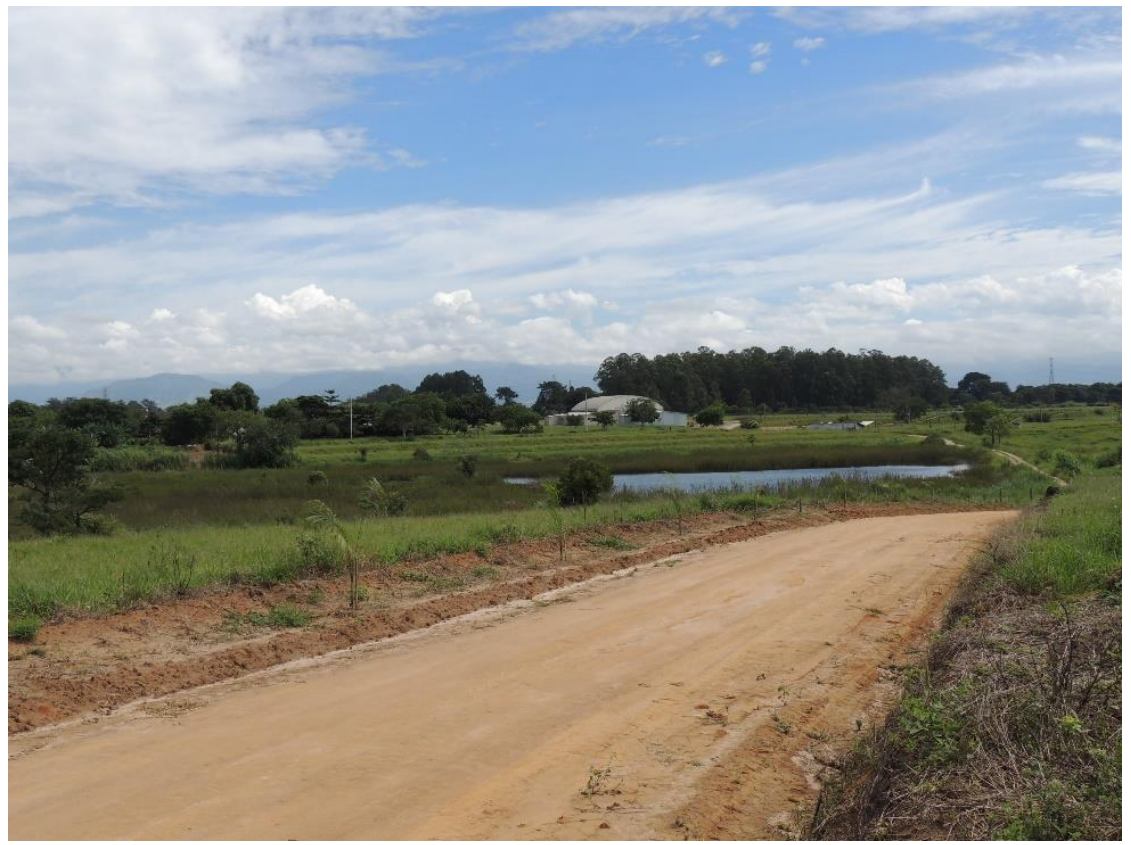

Fonte: Leal (2017).

Para a abertura dos furos, manteve-se o método da etapa anterior, com trado manual com copo tipo holandês, acoplado a extensões de $40 \mathrm{~cm}$, assim como o uso de peneiras de malha de $4 \mathrm{~mm}$, sustentadas por tripés de bambus para peneirar o material. Em todos os níveis, coletou-se solo para peneirar e conferiu-se a cor por meio da tabela de cores - Munsell (vide foto 7).

As sondagens nesse local foram distribuídas ao longo da vertente, sendo o primeiro furo efetuado a uma distância de 30 metros a partir da linha d'água, a 560 
metros de altitude, o segundo a 30 metros a partir desse, a 569 metros de altitude e o terceiro, a 30 metros do segundo, a 573 metros de altitude. Optou-se por não fazer a primeira sondagem a partir da linha d'água porque em etapa anterior, durante prospecção em outra área de depressão, o material arqueológico apareceu mais próximo do topo do interflúvio.

Foto 7 - Análise da cor do solo por meio do Munsell.

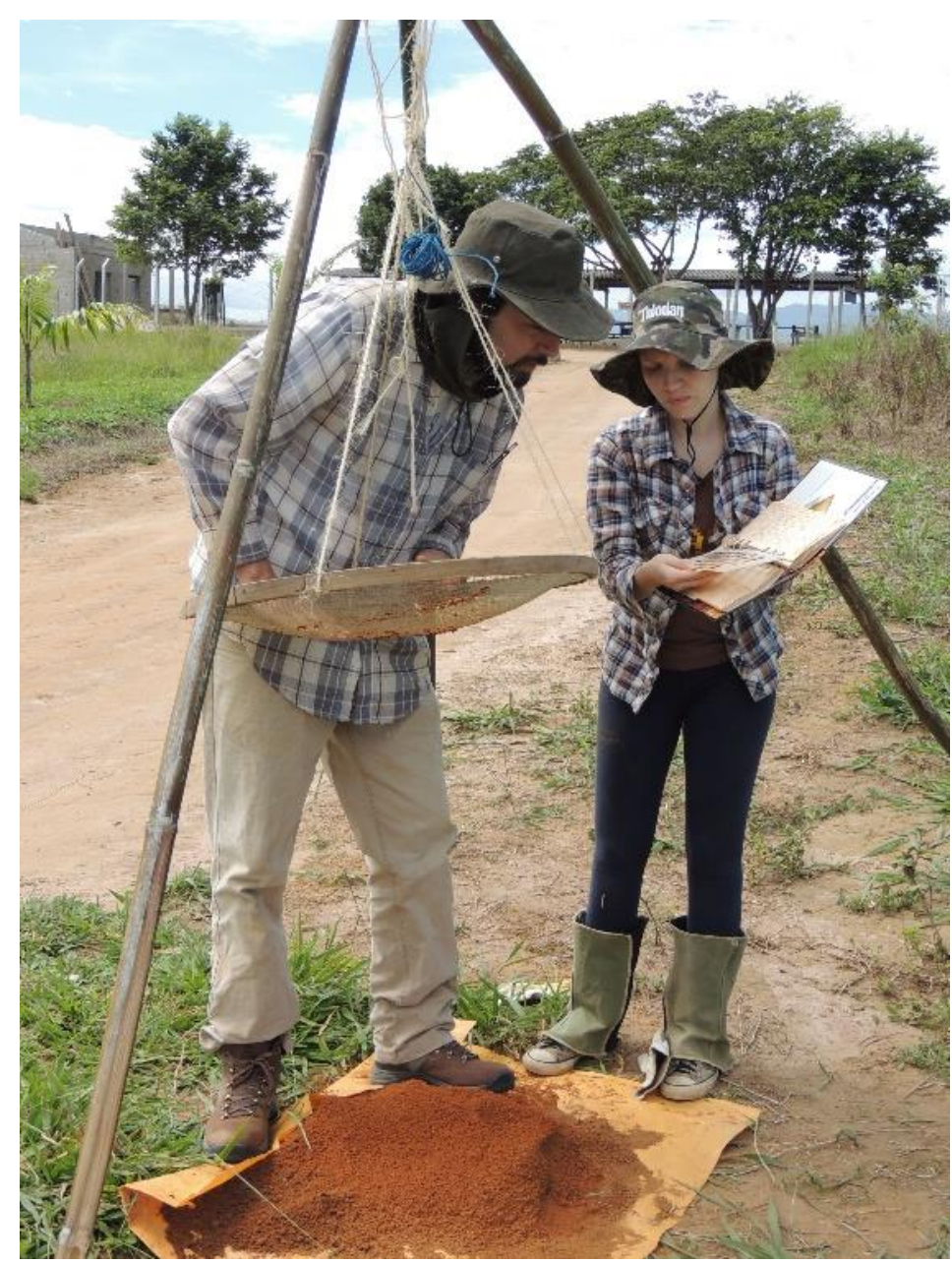

Fonte: Leal (2017).

O material encontrado e coletado constitui-se, predominantemente, de fragmentos de quartzo, feldspato e alguns micro carvões. As profundidades dos furos variaram de $320 \mathrm{~cm}$ no primeiro furo, $404 \mathrm{~cm}$ no segundo e 512 no terceiro. Em nenhuma dessas sondagens atingiu-se a camada rochosa.

$\mathrm{Na}$ área de morro, vide foto 8, cerca de 10 metros a partir do abrigo, foram feitas duas sondagens, distantes entre si, aproximadamente, três metros. A primeira (P30) foi aberta a 687 metros de altitude e encerrada em $26 \mathrm{~cm}$, pois o copo do trado 
bateu na rocha. A segunda (P31), aberta a 696 metros de altitude, distante 280 centímetros a norte de $\mathrm{P} 4$, foi até o final do trado, $550 \mathrm{~cm}$, mas não chegou-se a camada rochosa. Nessas sondagens foi encontrado o mesmo tipo de material achado nas outras da área de depressão, porém, nota-se que o tamanho dos fragmentos das últimas é maior.

Foto 8 - Área de prospecção em morro

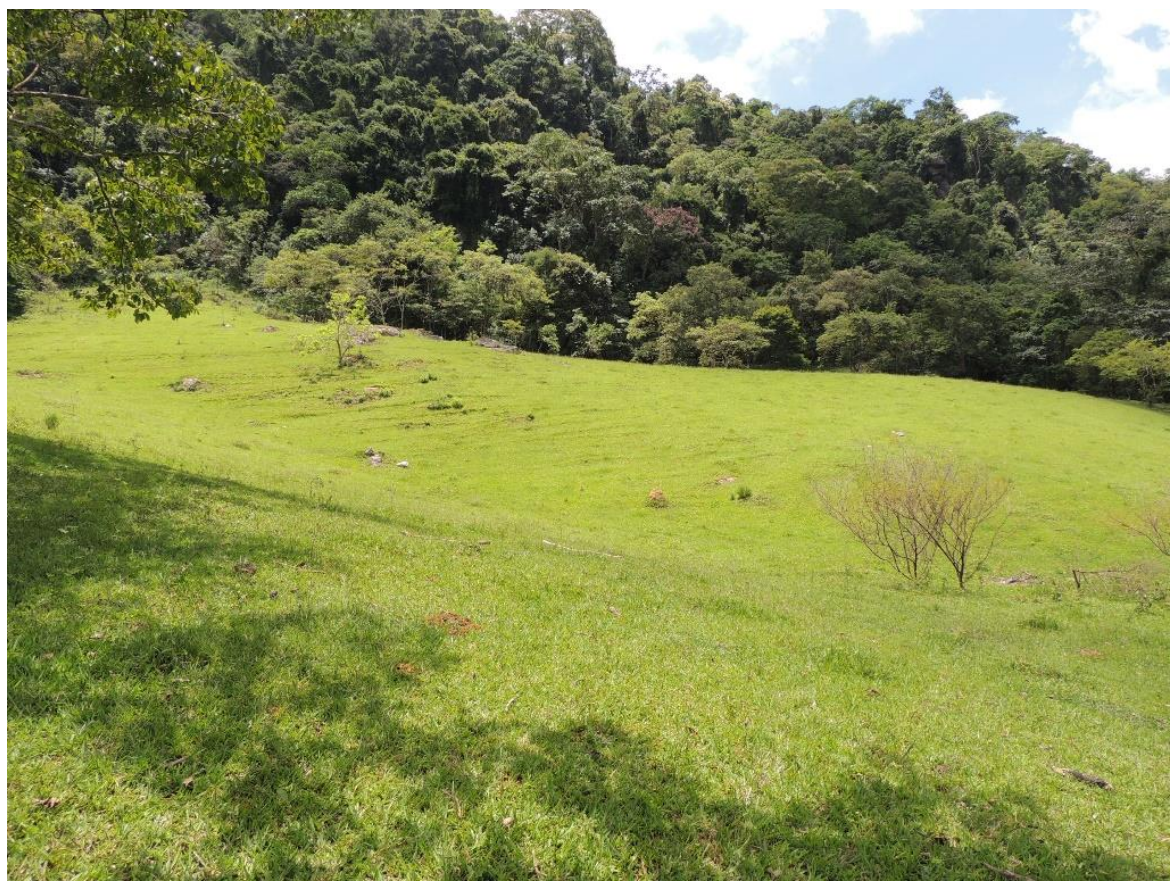

Fonte: Leal (2017).

A localização de todas as sondagens foi registrada por GPS e, ao final, todos os furos foram cobertos.

\subsubsection{Abertura de unidade de escavação}

A quadra foi aberta em área de colina, em propriedade particular da família Almeida, no Bairro do Pinga, no mesmo município. O local de sua abertura foi escolhido devido a sondagem anterior, na qual apareceram lascas de quartzo em níveis distintos (entre 49 e $57 \mathrm{~cm}$ e entre 140 e $150 \mathrm{~cm}$ ). A princípio, ela foi demarcada por quatro pontos, distantes entre si $100 \mathrm{~cm}$ e, a partir de cada um deles, mediu-se mais $10 \mathrm{~cm}$, onde foram fincados piquetes (Vide foto 9). Uma bússola foi usada para a orientação da mesma. 
A escavação da quadra se deu por níveis artificiais de 10 centímetros, com uso de colher, nível de bolha e trenas (vide foto 9). Toda a terra escavada foi peneirada e os materiais, coletados por nível, e na peneira, foram acondicionados em sacos zip, devidamente identificados. As coordenadas dela também foram marcadas por GPS.

Foram coletadas amostras de sedimento para estudos futuros. Fragmentos de carvão que apareceram no perfil não foram coletados, nesse momento, mas dois fragmentos encontrados nos níveis $13 \mathrm{~cm}$ e $26 \mathrm{~cm}$, ambos no quadrante NE, foram recolhidos.

Foto 9 - Escavação da Quadra A50

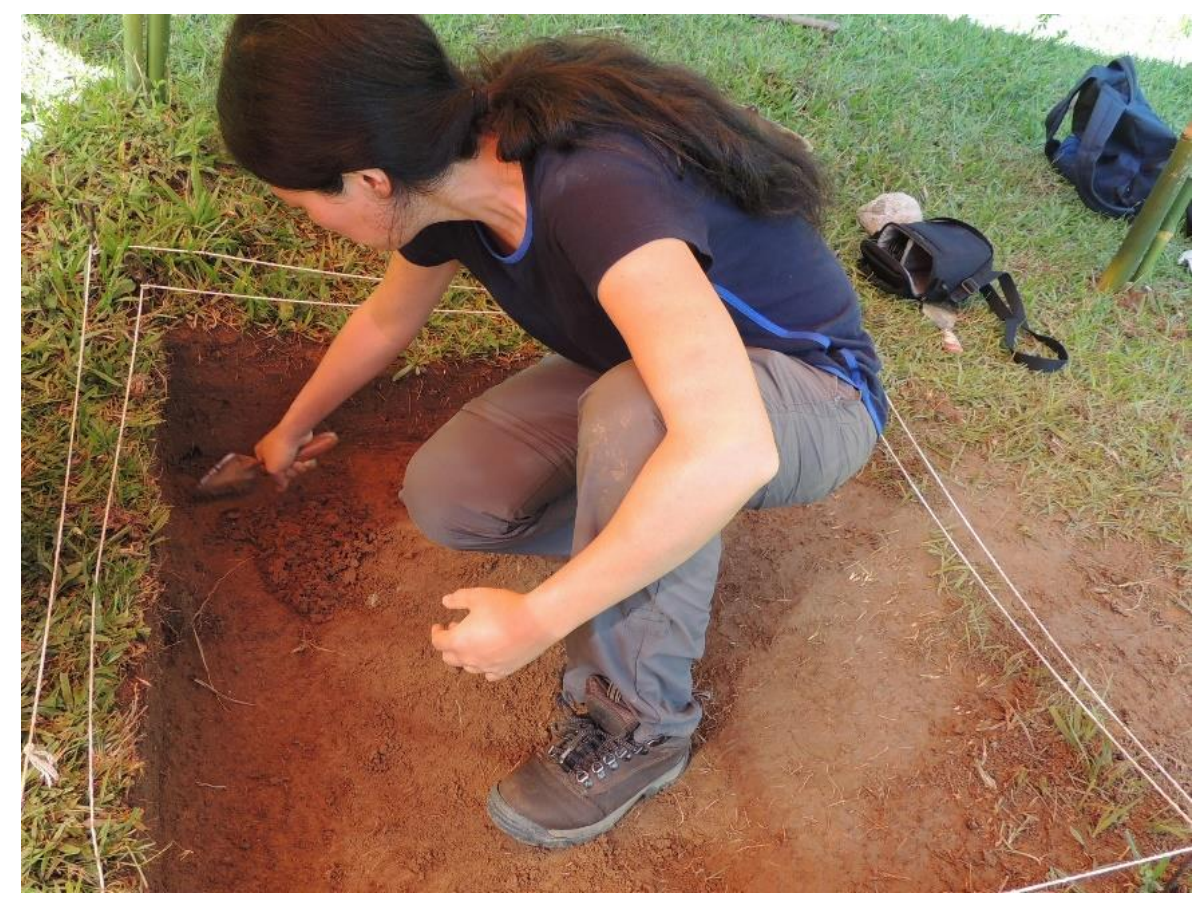

Fonte: Alarsa (2017).

Devido ao curto período do tempo dessa etapa de campo, e ao tipo de solo (latossolo amarelo e vermelho) a quadra foi baixada só até a profundidade suficiente para o seu nivelamento $(30 \mathrm{~cm})$.

\subsubsection{Prospecção em área de abrigo}

Um abrigo pequeno, formado por um paredão, distante cerca de 60 metros a leste de onde foi aberta a quadra, apresentou sulcos pequenos, alinhados, muito 
semelhantes a cúpules, que são feições encontradas em sítios rupestres. Vide foto 10.

Também foi realizada prospecção de superfície em outras áreas de abrigo, no interior da Falésia Paraíso, cuja base aflora cerca de 20 metros da quadra. Essa atividade foi acompanhada pelo professor Inácio Bianchi, da Universidade Estadual de São Paulo, Faculdade de Engenharia de Guaratinguetá, uma vez que o mesmo, por ser escalador, conhece a região e está familiarizado com a área.

Foto 10 - Cúpules em abrigo próximo a unidade escavação

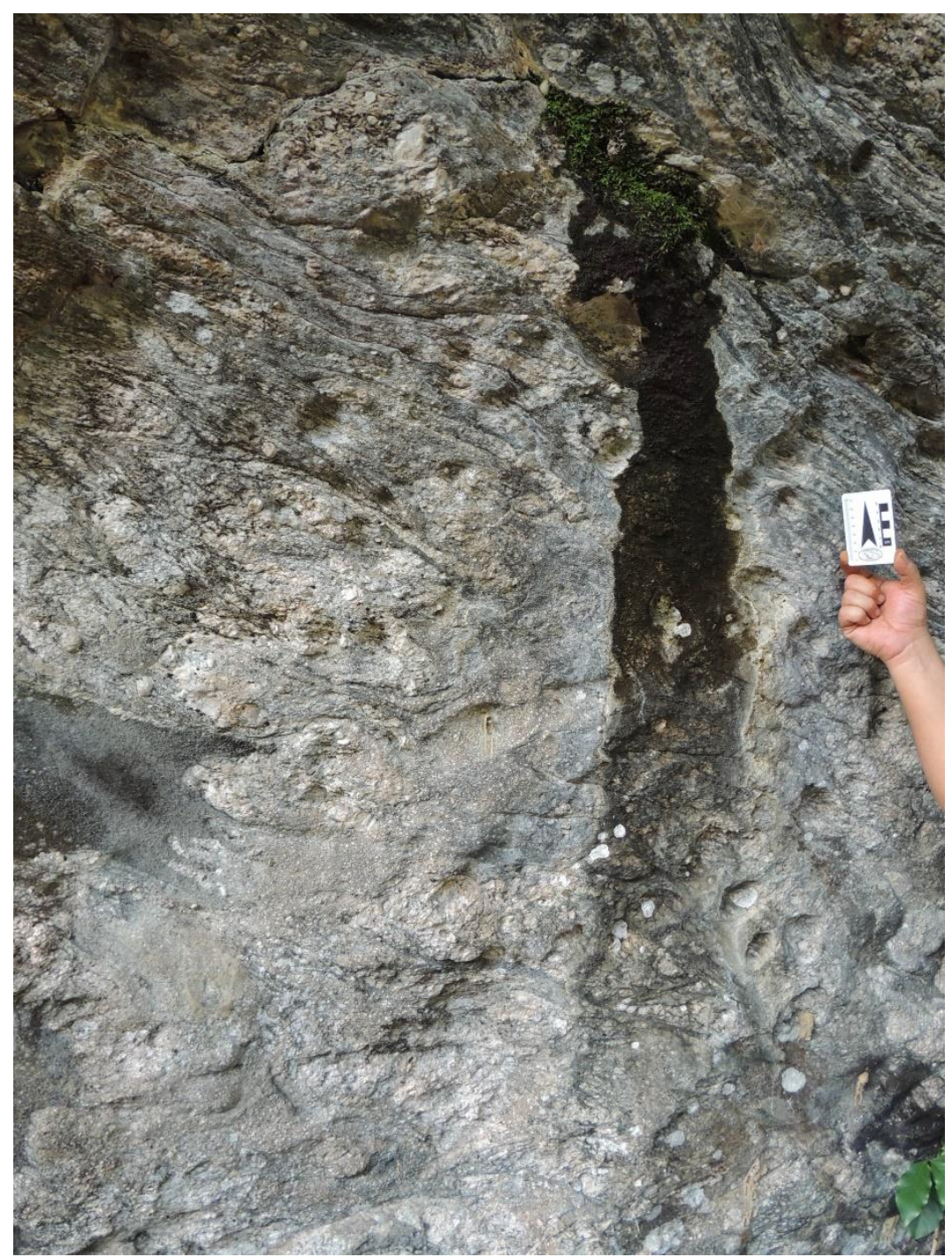

Fonte: Leal (2017).

Um dos abrigos é mais fechado (vide foto 11), sendo possível entrar pelas laterais e a sua altura do chão ao teto não alcança dois metros. Possui vestígios de ocupação recente, é um ambiente escuro e foi observado com luz artificial. Durante a prospecção não foi encontrado material arqueológico em superfície. 
Foto 11 - Abrigo rochoso na Falésia Paraíso

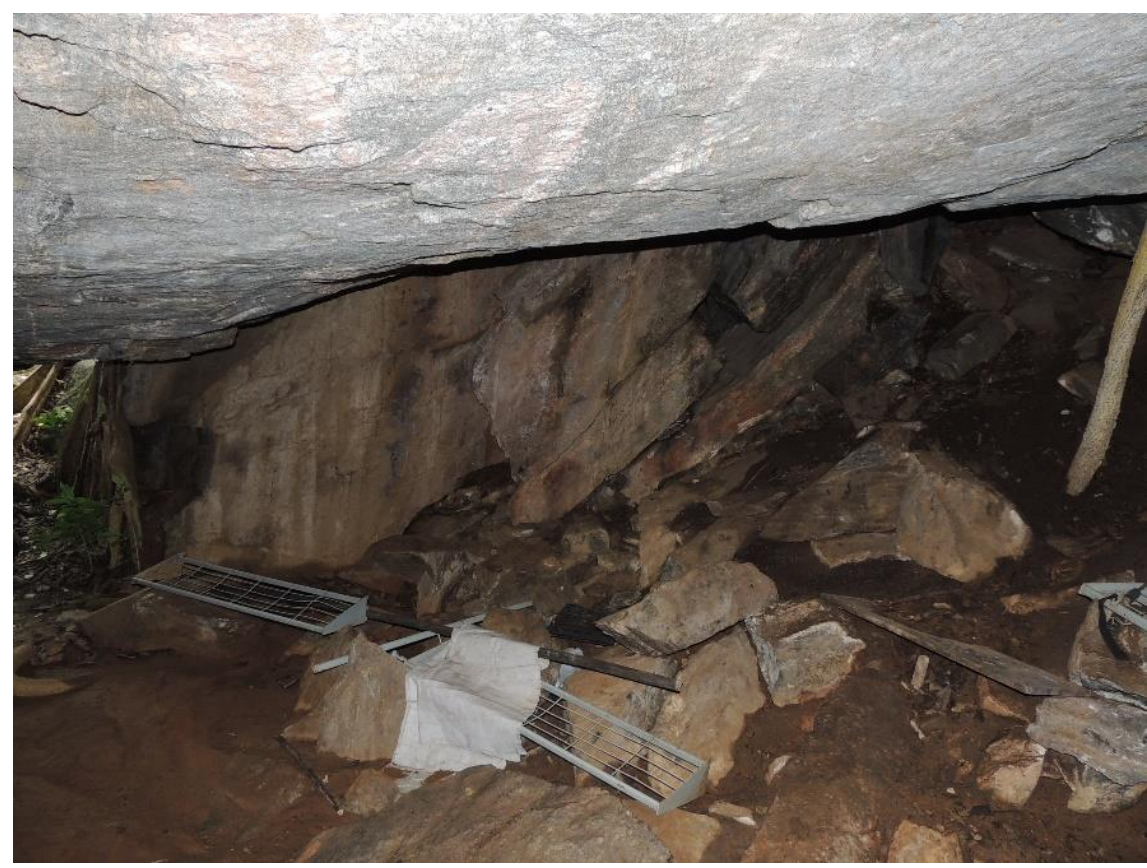

Fonte: Leal (2017).

Em outra área, mais aberta, subindo as rochas, foram identificadas linhas nas paredes, que, caso fossem encontradas junto com outras evidências de ação humana pretérita, poderiam ser consideradas como áreas de potencial para arte rupestre. Vide fotos 12 e 13. Porém, dadas as características geológicas da área, não se descarta a possibilidade dessas marcas serem feições naturais.

Foto 12 - Linhas na Falésia Paraíso.

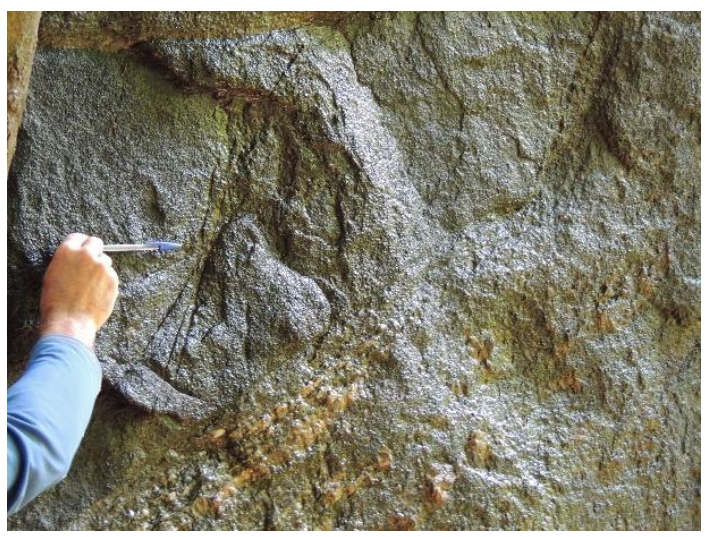

Fonte: Leal (2017).
Foto 13 - Linhas na Falésia Paraíso.

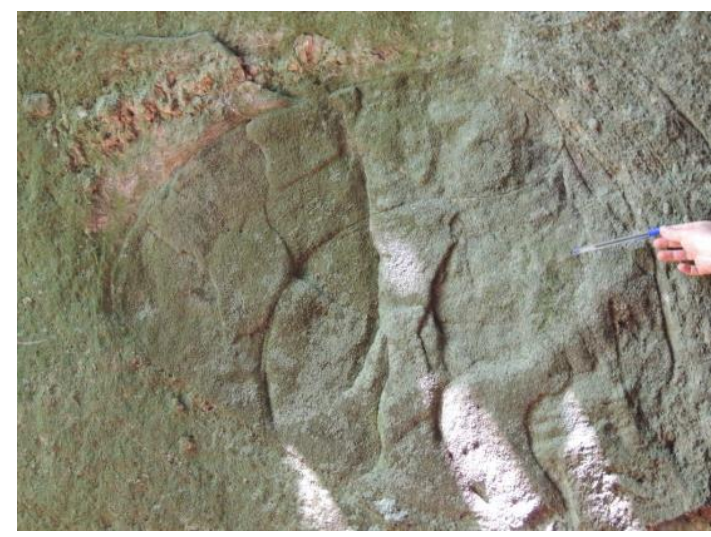

Fonte: Leal (2017).

Todo o material encontrado e coletado em todas as sondagens, na prospecção da área de abrigo e na quadra, foi encaminhado ao laboratório, passou por processo de curadoria e foi analisado quanto ao com potencial arqueológico. 
Há que se observar que na primeira etapa de campo, embora tenham sido feitas mais sondagens por trado, coletou-se menos material em relação a segunda etapa. O fato se deve a escolha do método de coleta, pois na primeira campanha, optou-se por coletar apenas o que, em campo, foi julgado como de potencial arqueológico, de modo que muito material foi descartado, sem a certeza de que não era de interesse arqueológico. Porém, na segunda etapa, decidiu-se por coletar tudo na peneira e analisar, posteriormente, em laboratório. 


\section{RESULTADOS}

\subsection{DADOS DAS SONDAGENS}

Durante as duas etapas de campo, foram abertas 31 sondagens por trado (tabela 5) e uma unidade de escavação $1 \mathrm{~m} \times 1 \mathrm{~m}$, em três áreas distintas, sendo duas próximas a depressões e uma em relevo colinar / de morros. A área da depressão D129 (figura 13), não apresentou material arqueológico.

Figura 13 - Depressão 129 na área 3

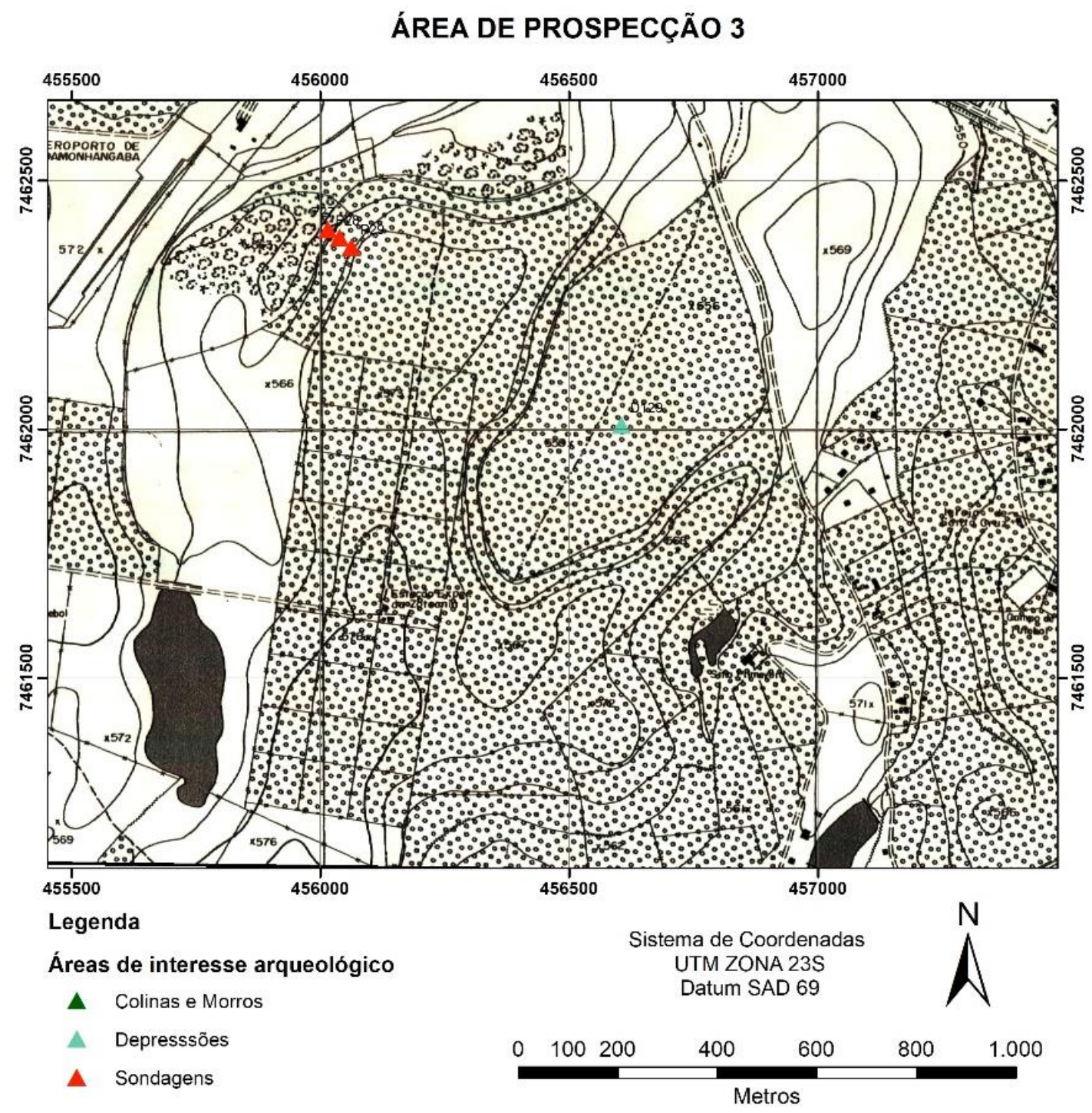

Fonte: IBGE, 1987. Recorte da Carta 1:10.000 do município de Pindamonhangaba. Org. Leal (2017). 
Desse total, foi identificada a presença de material arqueológico em 4 locais, cujas amostras foram recolhidas e analisadas em laboratório. Em três sondagens apareceram fragmentos de lascas e no outro, um fragmento de cerâmica. A seguir, segue breve descrição dessas áreas prospectadas.

Tabela 5 - Localização das sondagens

\begin{tabular}{c|c|c}
\hline Tradagem & Longitude & Latitude \\
\hline P1 & 450858,2 & 7475536,57 \\
\hline P2 & 450838,15 & 7475516,91 \\
\hline P3 & 450837,85 & 7475516,91 \\
\hline P4 & 450809,05 & 7475503,75 \\
\hline P5 & 450841,23 & 7475487,25 \\
\hline P7 & 450832,91 & 7475457,56 \\
\hline P8 a P12 & 450808,33 & 7475473,86 \\
\hline P13 & 450896,44 & 7475484,77 \\
\hline P14 & 440884,21 & 7475490,16 \\
\hline P15 & 449025,77 & 7462716,68 \\
\hline P16 & 449009,22 & 7462712,41 \\
\hline P17 & 448998,07 & 7462695,3 \\
\hline P18 & 448842,57 & 7462689,29 \\
\hline P19 & 450899,73 & 7462557,58 \\
\hline P20 & 450895,2 & 7475456,91 \\
\hline P21 & 450733,65 & 7475625,06 \\
\hline P22 & 450735,24 & 7475609,56 \\
\hline P23 & 450742,49 & 7475588,33 \\
\hline P24 & 448777,47 & 7462584,26 \\
\hline P25 & 448806,39 & 7462615,13 \\
\hline P26 & 448834,04 & 7462623,42 \\
\hline P27 & 456015 & 7462402 \\
\hline P28 & 456038,5 & 7462385,56 \\
\hline P29 & 456061,83 & 7462366,59 \\
\hline P30 & 450891,28 & 7475461,62 \\
\hline P31 & 450897,84 & 7475464,52 \\
\hline & &
\end{tabular}

Fonte: Prospecção arqueológica realizada entre janeiro e março de 2017. Org. Leal (2017).

\subsubsection{Análise dos perfis estratigráficos}

Para a realização dos furos, foi utilizado um trado manual de copo holandês. As profundidades alcançadas variaram de 10 a 550 centímetros, pois em algumas o trado chegou na rocha, de modo que esses pontos foram descartados da análise. O critério utilizado para a profundidade máxima foi o alcance do trado, de 
modo que as diferenças se devem também ao fato de termos utilizado um conjunto com extensões e campo até a décima oitava sondagem e depois, todas as extensões de dois conjuntos de trado em um copo.

Embora tenham sido realizadas 31 sondagens, julgou-se relevante ressaltar as características apenas daquelas nas quais o material com potencial arqueológico foi coletado. As tradagens denominadas P1, P3 e P7 foram realizadas ao longo da vertente de uma colina, em cuja base está um rio de terceira ordem, denominado Córrego do Pinga. Vide figura 14.

Durante as sondagens, foram observados aspectos do solo quanto a cor, com a amostra úmida e sob luz do sol direta, por meio da tabela de cores Munsell, edição de 2009, inclusões de rochas, minerais e de carvões, basicamente.

A cor é uma característica do solo que pode revelar indícios sobre a sua composição. Normalmente, óxido de ferro e matéria orgânica são identificados pela coloração que causam no solo. De acordo com Campos (2001), os teores de hematita no solo, por exemplo, podem ser determinados a partir de seus índices de avermelhamento, por meio da leitura de cor no sistema $L^{*} a^{*} b^{*}$ (no qual uma cor é identificada por três valores) ou por Munsell calculadas com dados de sensoriamento remoto.

Como discutido anteriormente, a carta geológica de Pindamonhangaba mostra para essa área, o Complexo Paraíba do Sul, formado por gnaisses e migmatitos blastomiloníticos, biotita gnaisses por vezes com granada, entre outras rochas. Ao longo de quase todas as tradagens apareceram fragmentos de mineral de quartzo de veio, alguns de feldspato e granada e outas rochas não identificadas. 
Figura 14 - Localização das sondagens na Área 1

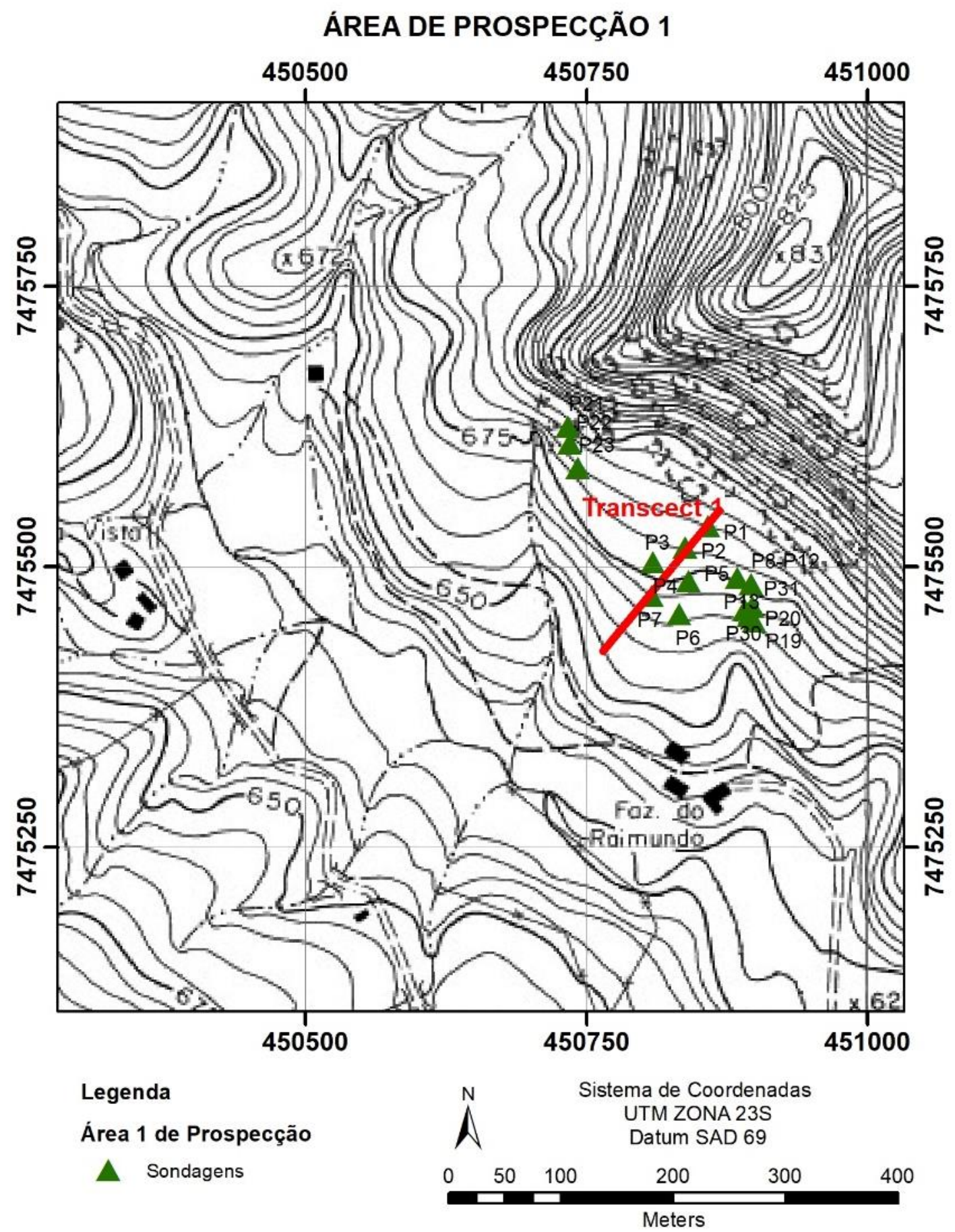

Fonte: IBGE, 1987. Recorte da Carta 1:10.000 do município de Pindamonhangaba. Org. Leal (2017). 


\section{Sondagem P1 e Quadra A50}

\section{UTM Long. 450858,2 e Lat. 7475536,57}

A sondagem $\mathrm{P} 1$ foi realizada na primeira etapa de campo, na área 1 (vide figura 14) na vertente de uma colina, a, aproximadamente, 685 metros de altitude, distante 27 metros da sondagem P3 e 82 metros da P7 (vide figura 15, onde o eixo y é a altitude e o x é a distância). O rio mais próximo, que está a 153 metros, é de primeira ordem, segundo a classificação de Strahler (1952).

Figura 15 - Distribuição das sondagens na vertente

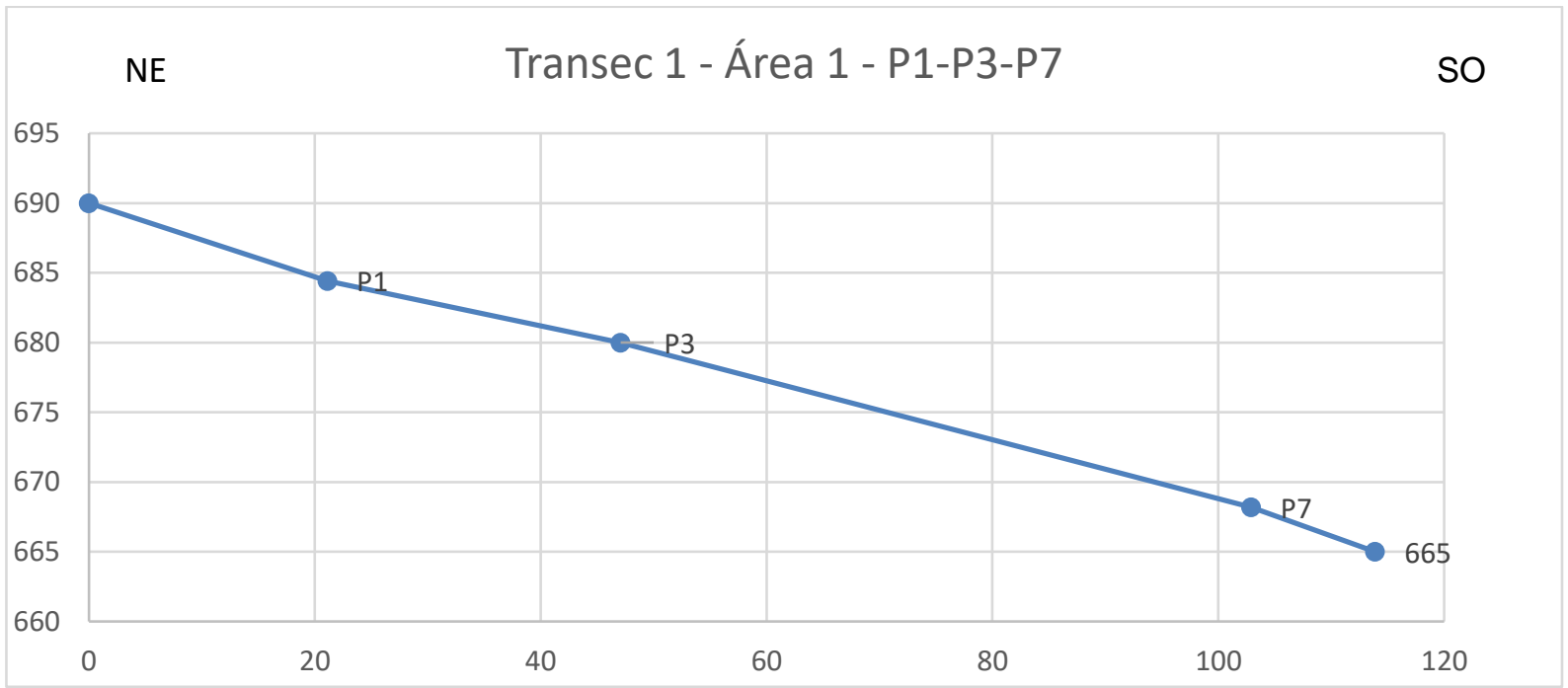

Fonte: Org. Leal (2017).

Nesse ponto, foram identificadas quatro cores para o solo, segundo a tabela de cores Munsell: 7.5YR 3/4 (Bruno-escuro) nos primeiros níveis até $21 \mathrm{~cm}$, 7.5YR 4/4 (Bruno) deste até o fim do nível 39, 7.5YR 4/6 (Bruno-forte) do nível 39 a $147 \mathrm{~cm}$ e 5YR 4/6 (Vermelho-amarelado) deste até o fim da sondagem. Vide figura 16.

Apareceram fragmentos de quartzo ao longo de quase todo o perfil, exceto entre os intervalos: $0-13 \mathrm{~cm}, 54-60 \mathrm{~cm}, 147$ a $151 \mathrm{~cm}, 183-188 \mathrm{~cm}, 215-221 \mathrm{~cm}$ e 241 - 243. Três amostras foram coletadas para análise quanto ao potencial arqueológico: um fragmento de quartzo, entre o intervalo de 13 a $21 \mathrm{~cm}$ e que apresentava manchas de óxido de manganês; um de rocha não identificada, no nível 39 a 49 e o terceiro de 
quartzo também, na camada entre 139 a $147 \mathrm{~cm}$. Os dois primeiros foram descartados por não apresentarem indícios de lascamento, porém, o que estava no nível mais profundo, a quase um metro e meio da superfície, apresenta algumas características que o classificaram, inicialmente, como duvidoso quanto ao potencial arqueológico.

Na segunda etapa de campo, no mesmo local, foi aberta uma unidade de escavação, denominada Quadra A50, a qual foi escavada até 30 centímetros de profundidade. A coloração aferida nesse intervalo foi 7.5YR 3/4 (Bruno-forte). Na unidade foi encontrada maior quantidade de minerais de quartzo de veio, de maior granulometria também (até $10 \mathrm{~cm}$ ), se comparada ao tamanho dos fragmentos encontrados durante a tradagem. A figura 16, abaixo, mostra as unidades estratigráficas nas quais foram encontrados materiais de interesse arqueológico.

Figura 16 - Perfis das unidades estratigráficas no morro

\section{Cor do solo e estratigrafia emárea de morro}
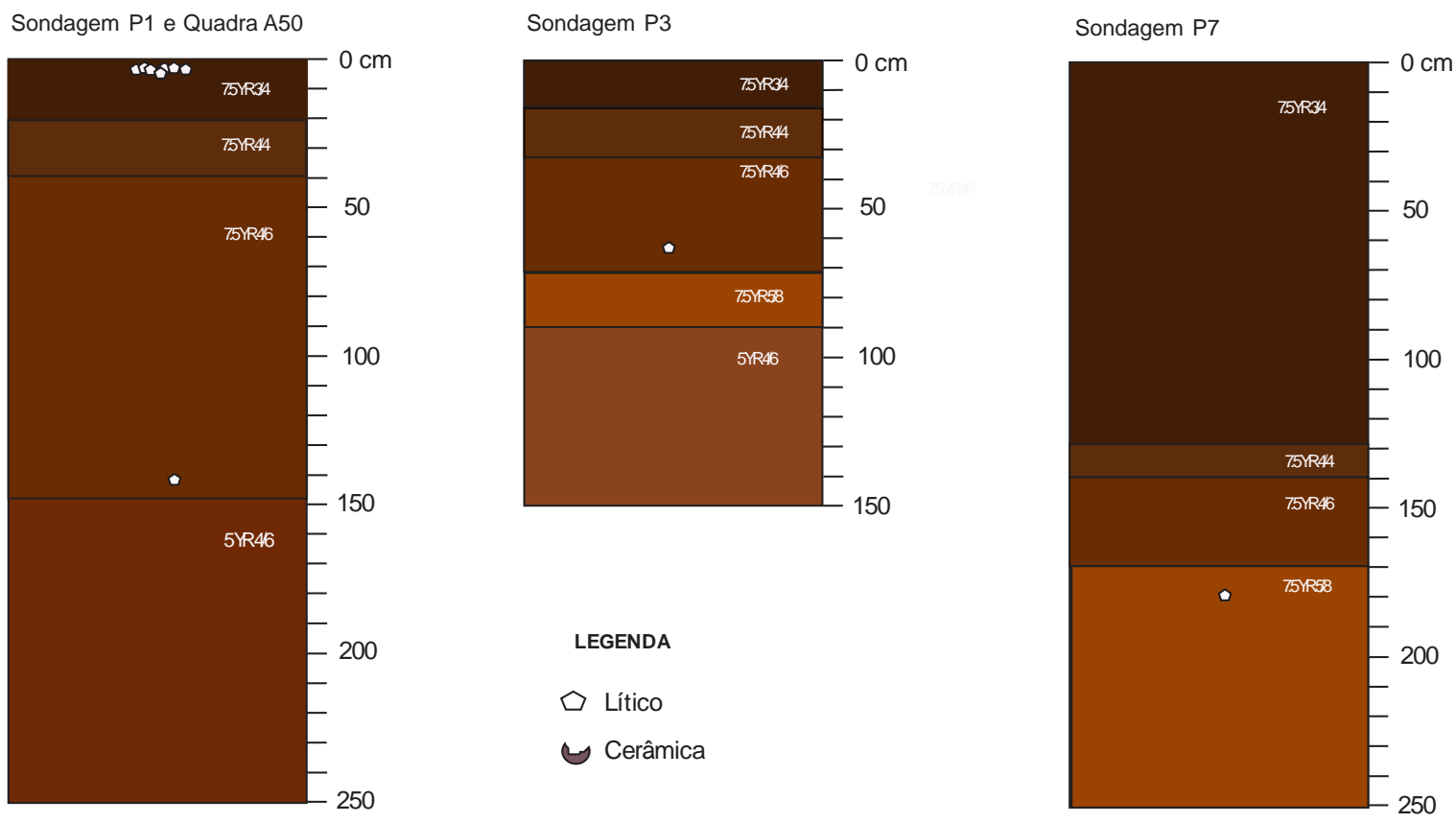

Fonte: Org. Leal (2017).

\section{Sondagens P3}

UTM Long. 450837,85 e Lat. 7475516,91 
A sondagem $\mathrm{P} 3$ foi realizada no mesmo período e vertente que a $\mathrm{P} 1$, mais a jusante desta, e a, aproximadamente, 56 metros de P7 (vide figuras 14 e 15), a 680 metros de altitude. Com relação a drenagem mais próxima, a mesma de P1, está a 128 metros de distância.

As cores identificadas para o solo com o Munsell foram: 7.5YR 3/4 (Brunoescuro) nos primeiros níveis até $16 \mathrm{~cm}, 7.5 \mathrm{YR} 4 / 4$ (Bruno) no segundo nível até 32 cm, 7.5YR 4/6 (Bruno-forte) até o nível 71, 7.5YR 5/8 (Bruno-forte) entre 71 e $90 \mathrm{~cm}$ e 5YR 4/6 (Vermelho-amarelado) deste até o fim da sondagem. Vide figura 16. Apareceram fragmentos de quartzo ao longo todo o perfil e um foi coletado no nível 57 a 68 centímetros para posterior. O mesmo também foi classificado como duvidoso quanto ao potencial arqueológico.

\section{Sondagens P7}

\section{UTM Long. 450808,33 e Lat. 7475473,86}

A sondagem P7 é a mais próxima de uma drenagem, situa-se a 92 metros do mesmo rio de primeira ordem acima mencionado, e a 195 metros do Córrego do Pinga, no qual o primeiro deságua e está a 668 metros de altitude. A partir da consulta ao Munsell foram aferidas as seguintes cores para o solo: 7.5YR $3 / 4$ (Bruno-escuro) dos primeiros níveis até $129 \mathrm{~cm}, 7.5 Y R$ 4/4 (Bruno) no nível 129 a $140 \mathrm{~cm}, 7.5$ YR 4/6 (Bruno-forte) deste até o nível 170 e 7.5YR 5/8 (Bruno-forte) deste nível o fim da sondagem. Vide figura 16.

Além de quartzo e feldspato, nessa tradagem, também apareceram concreções rochosas escuras, não identificadas e foram coletadas duas amostras: um fragmento de quartzo e um de feldspato caulinizado. Após análise o primeiro foi considerado duvidoso quanto ao potencial arqueológico e o segundo foi descartado quanto a esse parâmetro.

\section{Sondagens P26}

UTM Long. 448834,04 e Lat. 7462623,42 
A sondagem P26, diferente das outras, foi feita em uma região de relevo mais aplainado, às margens de uma grande depressão, denominada Lagoa do Paturi. A dimensão da área total de drenagem, aferida por diferenciação de altitude, por meio da estereoscopia, foi calculada em 521.408,63 metros.

Nesse local, foram realizadas 8 sondagens das quais (vide figura 17), nenhuma atingiu a rocha. As profundidades dos furos variaram de 60 a 497 centímetros. Os três furos mais próximos a área úmida (p14, p15 e p16) atingiram o nível d'água entre 60 e 63 centímetros, e o próximo da sequência, subindo o terreno (P17), foi até $235 \mathrm{~cm}$, distando 13 metros, aproximadamente, do ponto anterior. O material encontrado em P17 é constituído de fragmentos de quartzo intemperizado em quase todos os níveis, exceto entre 125 e $154 \mathrm{~cm}$ e no fim da tradagem, de 220 a 235 centímetros. 
Figura 17 - Prospecção em área de depressão

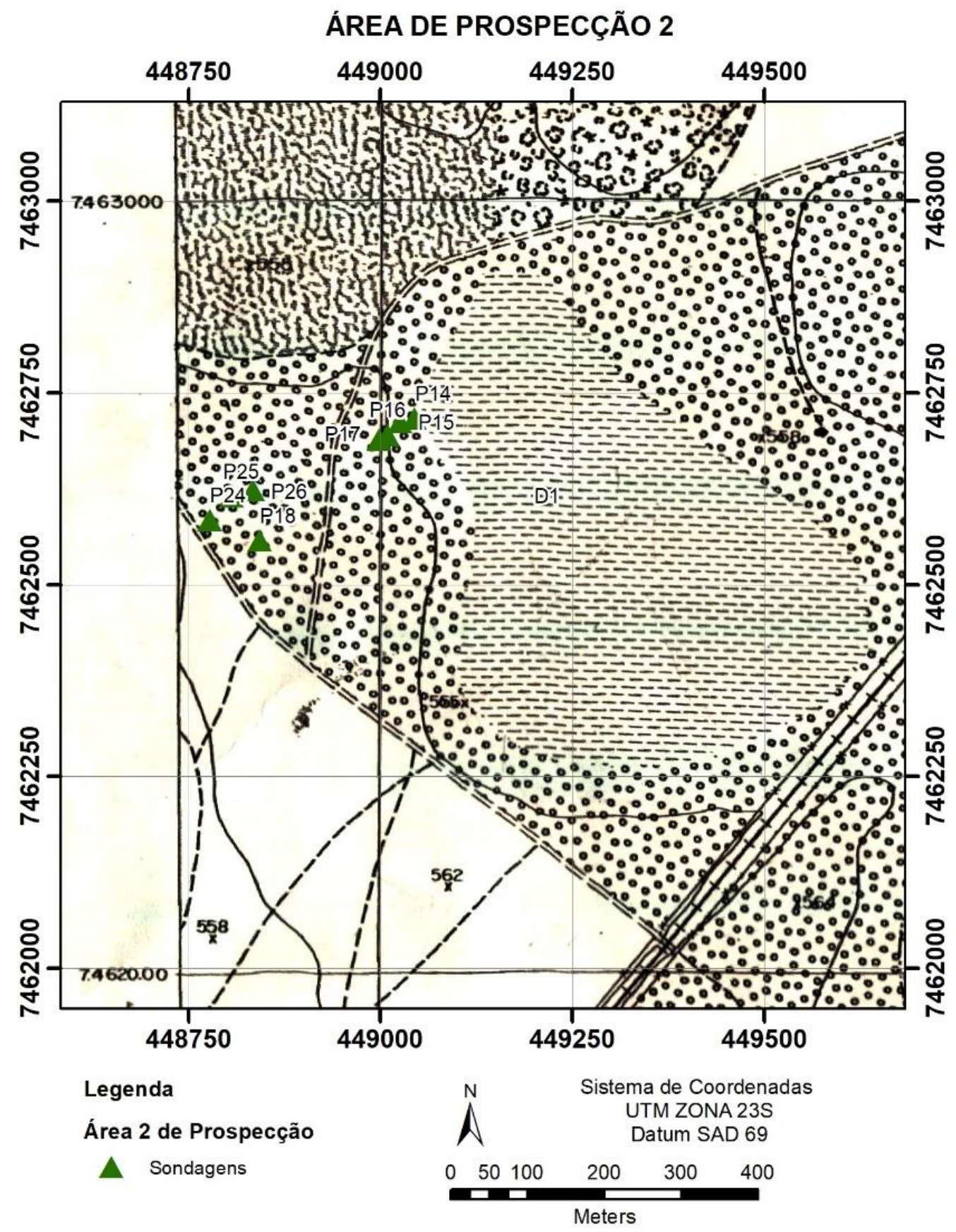

Fonte: IBGE, 1987. Recorte da Carta 1:10.000 do município de Pindamonhangaba. Org. Leal (2017).

Como a análise, em campo, do sedimento encontrado em P17 não apresentou potencial arqueológico ou diferenciação quanto aos tipos de minerais, optou-se por continuar a prospecção a partir de uma distância maior da linha d'água, mas dessa vez fazendo furos em direção a lagoa. 
Na sondagem P26, distante cerca de 243 metros da área úmida, apareceu um fragmento de cerâmica entre os níveis 302 e 310 . Além dele, foram encontrados e coletados 4 fragmentos de quartzo, que após analisados, foram desconsiderados quanto ao potencial arqueológico.

As cores identificadas para o solo com o Munsell foram: 10YR 3/3 (Brunoescuro) no primeiro nível até $13 \mathrm{~cm}, 10 \mathrm{YR} 3 / 4$ (Bruno-amarelado-escuro) no segundo nível até 47 cm, 10YR 4/4 (Bruno-amarelado-escuro) até o nível 95, 10YR 4/6 (Brunoamarelado-escuro) entre 95 e $310 \mathrm{~cm}, 10$ YR 5/6 (Bruno-amarelado) deste até o nível 469 e 10YR 5/8 (Bruno-amarelado) a partir deste até o fim da sondagem. Vide figura 18.

Além da presença de quartzo em vários níveis, nos iniciais, foram observados fragmentos de rocha não identificada. Essa sondagem foi encerrada em 497 centímetros, que foi máximo alcançado pelo trado.

Por meio da estereoscopia, notou-se que a área de captação de água das depressões, ou seja, dos limites dos interflúvios, é bem maior que a área úmida. As tradagens iniciais ao redor da Lagoa do Paturi, representada no mapa de potencial arqueológico (vide mapas 1 e 2) foram feitas dentro da área de captação, local onde são mais frequentes os processos de depósito de sedimentos. Esse fato nos permite refletir se o fato de não ser encontrado material arqueológico mais próximo à linha d'água não seria porque o mesmo foi rolado para o fundo da depressão ou deteriorado devido a processo físicos e, principalmente, químicos, comuns em áreas de solo hidromórfico.

O aspecto do quartzo encontrado nessa área, bastante alterado, bem como o encontrado na Área 3, também de depressão, demonstra que o mesmo dever ter sofrido o ataque de ácidos, além de ter sido transportado.

A profundidade onde a cerâmica foi achada também causa certo estranhamento, visto que esse tipo de material costuma ser encontrado em níveis mais rasos ou mesmo na superfície. Embora a carta topográfica de Pindamonhangaba não abranja mais detalhes do relevo dessa área, sabe-se que o fragmento foi achado em área de declive, oposta à depressão, de modo que poderíamos pensar em processos de coluvionamento para explicar a estratigrafia. Outro motivo poderia ser o rolamento do material de um nível mais superficial para dentro do buraco feito pelo trado, ou seja, desprendido da parede durante o processo de tradagem. 
Figura 18 - Perfil das unidades estratigráficas na área de depressão

$$
\text { Sondagem P26 }
$$

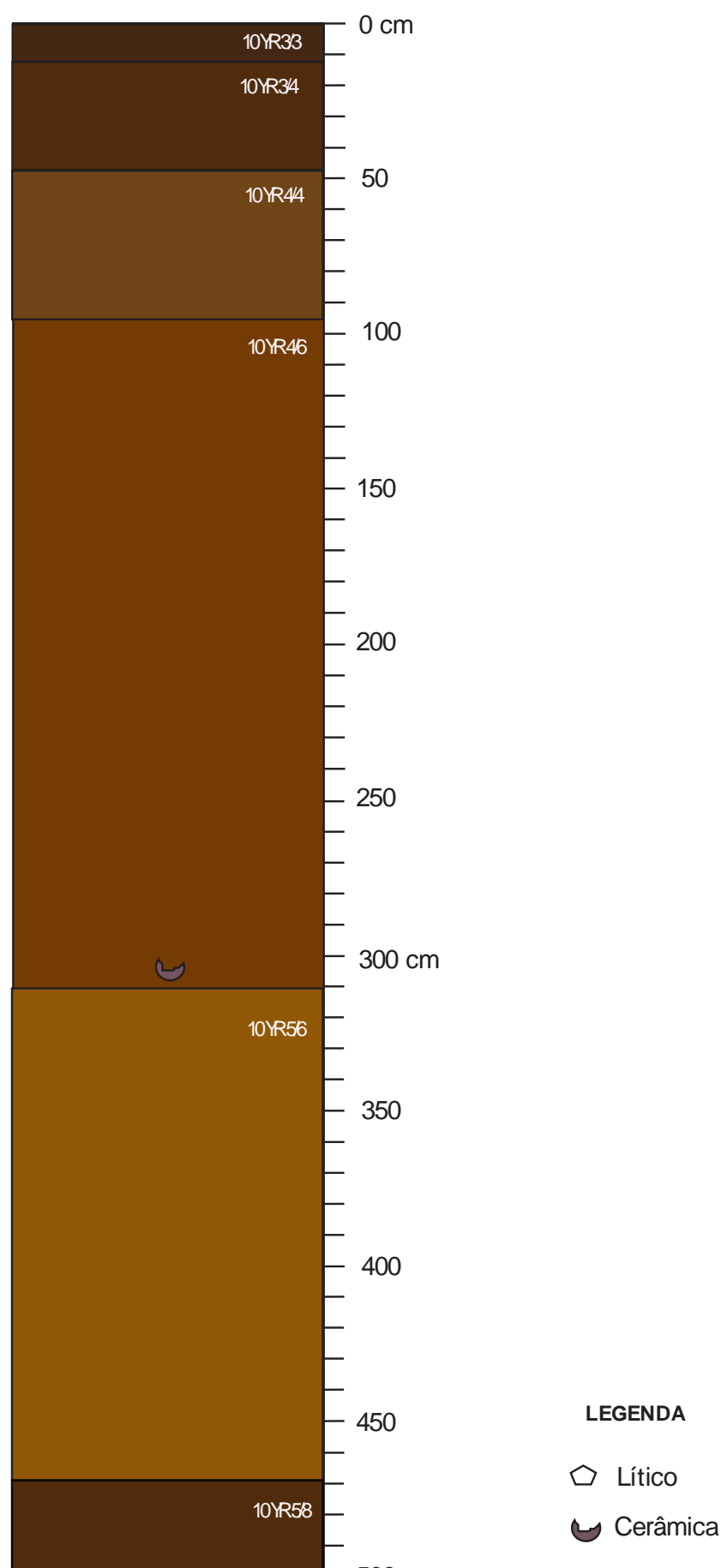

Fonte: Org. Leal (2017). 


\title{
6.2 DESCRIÇÃO DO MATERIAL ESCAVADO
}

Nesse tópico apresenta-se uma breve descrição dos materiais lítico e cerâmico, coletados durante as atividades de prospecção arqueológica.

\subsubsection{Descrição do material lítico}

Em decorrência do tamanho reduzido da amostra de material lítico (10 peças), coletada durante as tradagens e a abertura da unidade de escavação $1 \mathrm{~m} \mathrm{x}$ $1 \mathrm{~m}$, denominada quadra $A 50$, optou-se pela descrição individual de cada peça.

De acordo com Laming-Emperaire (1967, p.35), uma lasca pode ser definida como

\begin{abstract}
Fragmento de rocha, debitado por uma percussão, aplicada em um ponto determinado do núcleo. A lasca apresenta, tipicamente, um plano de percussão (a superfície sobre a qual foi aplicada a percussão), uma face externa (a que se encontrava no exterior do núcleo antes da debitagem), uma face interna (a que se encontrava no interior do núcleo antes da debitagem).
\end{abstract}

Embora não seja apresentada uma ficha de classificação de material lítico, foram elencados alguns atributos genéricos, observados em todas as amostras: dimensões, presença de talão, feições positivas de lascamento e peso. A seguir, verificou-se em cada unidade a presença de alguns atributos de lascamento: tipo de talão, tipo de bulbo, terminação da lasca e negativos de retirada. Tanto os atributos genéricos como os atributos de lascamento constituem parâmetros baseados nos modelos de classificação de material lítico apresentados por Morais (1987) e por Araujo (2001).

Para se aferir o tamanho das peças foi utilizado um paquímetro eletrônico da marca "Sylvac System", modelo S 235 PAT $(0-150 \mathrm{~mm})$ S - Cal Work. E para o cálculo do peso, usou-se uma balança de precisão semi-analítica, modelo AS 5.500, 0,01 g de precisão, da marca "Marta".

Todas as peças foram fotografadas com uma máquina fotográfica Nikon, Coolpix, modelo P510 de modo que a câmera ficasse posicionada a um ângulo de 90ํㅡㄴ das amostras e a luz artificial principal, posicionada a noroeste das mesmas. O registro 
foi feito de modo sistemático, e procurou-se obedecer a seguinte ordem: $1^{\text {a }}$. foto: talão para sul e face interna virada para cima; $2^{\text {a }}$. foto: talão para sul e face interna virada para oeste; $3^{a}$. foto: talão para cima e face interna para norte; $4^{a}$. foto: talão para baixo e face interna para sul; 5‥ foto: talão para sul e face interna para leste e 6ㄹ. foto: talão para sul e face externa para cima.

\section{Amostras P1, P3 e P7 - Tradagens}

As três peças descritas a seguir foram coletadas durante as tradagens. $O$ quartzo é a matéria-prima de todas.

\section{Amostra P1}

Não possui talão, de modo que foram aferidas suas dimensões gerais, em milímetros:

\begin{tabular}{|ccc|}
\hline Comprimento & Largura & Espessura \\
27,08 & 17,67 & 8,95 \\
\hline
\end{tabular}

Seu peso é de 4,35 gramas. O suporte não é identificável. Apresenta apenas dois negativos de retirada. Não apresenta: córtex, retoques, bulbo, sinais de uso ou feições positivas de lascamento. Foi classificada como um fragmento de lasca. Para se fotografar esta peça, considerou-se a base maior equivalente ao "talão" das demais, de modo a primeira foto foi tirada posicionada com a base maior voltada para sul e a face interna voltada para cima; a segunda com a base maior para sul e a face interna para a oeste. A mesma sequência foi adotada até a última foto. Vide pranchas em anexo.

\section{Amostra P3}

Possui talão esmagado e a partir de sua identificação, foram aferidas as seguintes dimensões, em milímetros: 


\begin{tabular}{|ccc|}
\hline Comprimento & Largura & Espessura \\
7,90 & 15,28 & 4,33 \\
& Maior & Dimensão perpendicular ao plano \\
Medidas do & dimensão & horizontal \\
talão & horizontal & \\
& 5,97 & 2,64 \\
\hline
\end{tabular}

Seu peso é de 0,53 gramas. O suporte não é identificável. Apresenta um negativo de retirada. Não apresenta: córtex, retoques, bulbo, sinais de uso e feições positivas de lascamento. Foi classificada como uma lasca unipolar terminada em fratura. Vide anexos.

\section{Amostra P7}

Possui talão liso e a partir de sua identificação, foram aferidas as seguintes dimensões, em milímetros:

\begin{tabular}{|ccc|}
\hline Comprimento & Largura & Espessura \\
19,88 & 11,92 & 7,28 \\
& Maior & Dimensão perpendicular ao plano \\
Medidas do & dimensão & horizontal \\
talão & horizontal & \\
& 7,48 & 3,39 \\
\hline
\end{tabular}

Seu peso é de 1,69 gramas. O suporte não é identificável. Apresenta dois negativos de retirada e como uma feição positiva de lascamento, ponto de impacto. Não apresenta: córtex, retoques, bulbo e sinais de uso. Foi classificada como uma lasca unipolar terminada em fratura.

Amostra 1A - Quadra 
Esta peça foi coletada na quadra A50, nível 3. O quartzo foi o mineral identificado como matéria-prima. Possui talão liso e a partir de sua identificação, foram aferidas as seguintes dimensões, em milímetros:

\begin{tabular}{|ccc|}
\hline Comprimento & Largura & Espessura \\
10,10 & 12,92 & 5,00 \\
& Maior dimensão & Dimensão perpendicular ao plano \\
Medidas do talão & horizontal & horizontal \\
& 8,40 & 2,26 \\
\hline
\end{tabular}

Seu peso é de 0,70 gramas. O suporte não é identificável. Como uma feição positiva de lascamento, nota-se a presença de ponto de impacto. Não apresenta: córtex, retoques, bulbo, sinais de uso e negativos de retirada. Foi classificada como uma lasca unipolar terminada em fratura.

\section{Amostra 2A - Quadra}

Esta peça foi coletada na peneira da quadra A50, nível 3, durante a retificação de perfil NO / NE. Quanto a matéria-prima, foi identificada como quartzo. Possui talão liso e a partir de sua identificação, foram aferidas as seguintes dimensões, em milímetros:

\begin{tabular}{|ccc|}
\hline Comprimento & Largura & Espessura \\
11,49 & 5,28 & 2,37 \\
& Maior & Dimensão perpendicular ao plano \\
Medidas do & dimensão & horizontal \\
talão & horizontal & \\
& 3,45 & 3,25 \\
\hline
\end{tabular}

Seu peso é de 0,20 gramas. O suporte não é identificável. Como uma feição positiva de lascamento, nota-se a presença de ponto de impacto. Não apresenta: córtex, retoques, bulbo, sinais de uso e negativos de retirada. Foi classificada como uma lasca unipolar terminada em fratura. 
Amostras 1B, 2B, 3B, 4B e 5B - Quadra

As cinco peças descritas a seguir foram coletadas na peneira da quadra A50, nível 3. O quartzo é a matéria-prima de todas.

\section{Amostra 1B}

Possui talão parcialmente ausente e liso e a partir de sua identificação, foram aferidas as seguintes dimensões, em milímetros:

\begin{tabular}{|ccc|}
\hline Comprimento & Largura & Espessura \\
10,12 & 6,13 & 2,92 \\
& Maior & Dimensão perpendicular ao plano \\
Medidas do & dimensão & horizontal \\
talão & horizontal & \\
& 5,12 & 2,05 \\
\hline
\end{tabular}

Seu peso é de 0,21 gramas. O suporte não é identificável. Como uma feição positiva de lascamento, nota-se a presença de ponto de impacto. Não apresenta: córtex, retoques, bulbo, sinais de uso e negativos de retirada. Foi classificada como uma lasca unipolar terminada em fratura.

\section{Amostra 2B}

Possui talão liso e a partir de sua identificação, foram aferidas as seguintes dimensões, em milímetros:

\begin{tabular}{|ccc|}
\hline Comprimento & Largura & Espessura \\
15,72 & 8,73 & 5,90 \\
& Maior & Dimensão perpendicular ao plano \\
Medidas do & dimensão & horizontal \\
talão & horizontal & \\
\hline
\end{tabular}


Seu peso é de 0,89 gramas. O suporte não é identificável. Apresenta superfícies convexas e bulbo saliente como feição positiva de lascamento, além de três negativos de retirada. Não apresenta: córtex, retoques e sinais de uso. Foi classificada como uma lasca unipolar terminada em fratura.

\section{Amostra 3B}

Possui talão liso e a partir de sua identificação, foram aferidas as seguintes dimensões, em milímetros:

\begin{tabular}{|ccc|}
\hline Comprimento & Largura & Espessura \\
13,18 & 7,11 & 3,20 \\
& Maior & Dimensão perpendicular ao plano \\
Medidas do & dimensão & horizontal \\
talão & horizontal & \\
& 4,83 & 2,10 \\
\hline
\end{tabular}

Seu peso é de 0,35 gramas. O suporte não é identificável. Não apresenta: córtex, retoques, sinais de uso, bulbo, feições positivas de lascamento, ou negativos de retirada. Foi classificada como uma lasca unipolar terminada em fratura.

\section{Amostra 4B}

Não possui talão, de modo que foram aferidas suas dimensões gerais, em milímetros:

\begin{tabular}{|ccc|}
\hline Comprimento & Largura & Espessura \\
8,60 & 6,34 & 4,15 \\
\hline
\end{tabular}


Seu peso é de 0,22 gramas. O suporte não é identificável. Não apresenta: córtex, retoques, bulbo, sinais de uso, feições positivas de lascamento, ou negativos de retirada. Foi classificada como um fragmento de lasca.

\section{Amostra 5B}

Possui talão liso e a partir de sua identificação, foram aferidas as seguintes dimensões, em milímetros:

\begin{tabular}{|ccc|}
\hline Comprimento & Largura & Espessura \\
9,03 & 13,46 & 7,56 \\
& Maior dimensão & Dimensão perpendicular ao plano \\
Medidas do talão & horizontal & horizontal \\
& 10,20 & 4,58 \\
\hline
\end{tabular}

Seu peso é de 0,70 gramas. O suporte não é identificável. Apresenta dois negativos de retirada. Não apresenta: córtex, retoques, bulbo, sinais de uso e feições positivas de lascamento. Foi classificada como uma lasca unipolar terminada em fratura.

\subsubsection{Descrição do material cerâmico}

O fragmento de cerâmica, coletado durante as tradagens, apareceu na peneiragem do sedimento retirado do nível $302-310 \mathrm{~cm}$. Como se trata de apenas de uma peça, optou-se por sua descrição geral, baseada em critérios adotados por Lopes (2014), que também analisou peças da região do Vale do Paraíba.

A peça foi medida com um paquímetro eletrônico da marca "Sylvac System", modelo S 235 PAT $(0-150 \mathrm{~mm}) \mathrm{S}$ - Cal Work. E para o cálculo do peso, usou-se uma balança de precisão semi-analítica, modelo AS 5.500, 0,01 g de precisão, da marca "Marta". Seu registro fotográfico foi feito por uma máquina fotográfica Nikon Coolpix, modelo P510, uma lupa USB Dino Lite e por um microscópio modelo Axio Cam 1Cc5, Stereo microscópio discover V8 Zeiss, operado pelo sr. José 
Maria Azevedo Sobrinho, pesquisador do Núcleo de Geologia Geral do IG - Instituto Geológico, que também auxiliou na identificação dos minerais presentes na cerâmica.

\section{Atributos gerais}

\begin{tabular}{|ccc|}
\hline Peso (em gramas) & Espessura da parede $(\mathrm{mm})$ & Espessura do lábio $(\mathrm{mm})$ \\
5,22 & 9,55 & 9,55 \\
\hline
\end{tabular}

O fragmento foi classificado como uma borda. Vide foto 14 .

Foto 14 - Fragmento de cerâmica - face interna

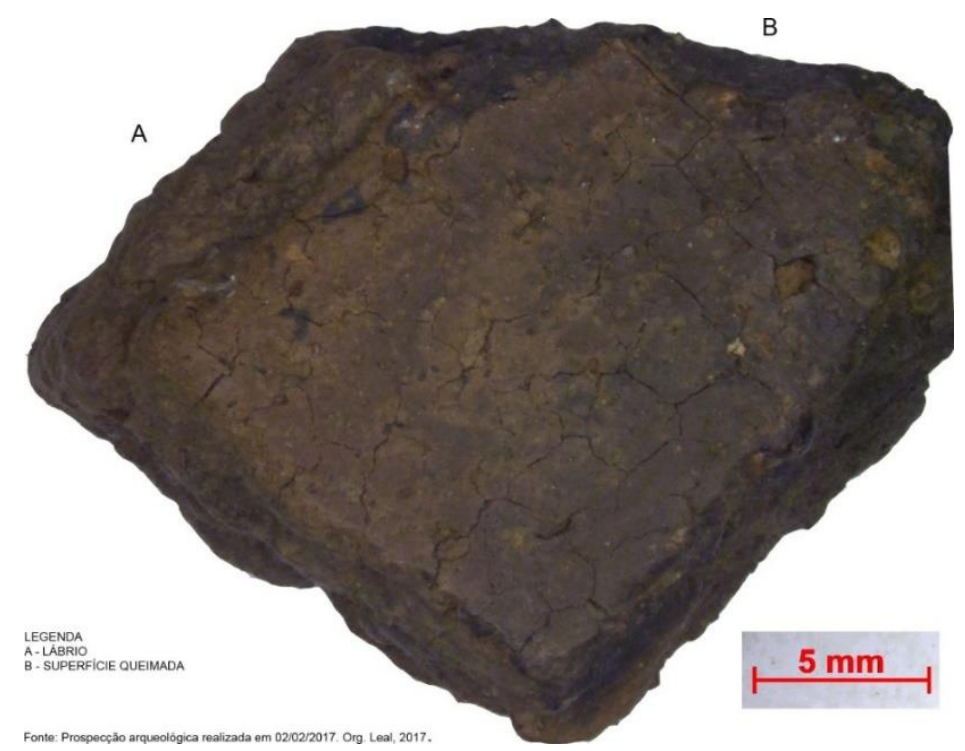

Fonte: Prospecção arqueológica realizada em 02/02/2017.

Aparenta queima com núcleo redutor, não homogênea, devido a coloração escura em algumas porções. Nota-se uma superfície mais polida, embora fraturada. Vide foto 15.

Na borda externa, pode ser vista uma "estria", cuja presença não é possível inferir se proposital ou acidental, devido a aderência de alguma raiz durante sua fabricação, por exemplo (vide prancha 11, item A, em anexo). A massa (antiplástico) é composta por minerais, e dentre eles, foi possível reconhecer fragmentos de quartzo de veio, com fratura conchoidal e de quartzo sacaroide, indicados na prancha 11, item $\mathrm{B}$ e foto 17. Acima da massa, há uma camada escura (placoide) que pode ser argila queimada, conforme indicado na prancha 11 , item $\mathrm{C}$ e na fotos 16 e 18. 
Foto 15 - Fragmento de cerâmica - lábio e superfície "polida"

Superfície "polida"
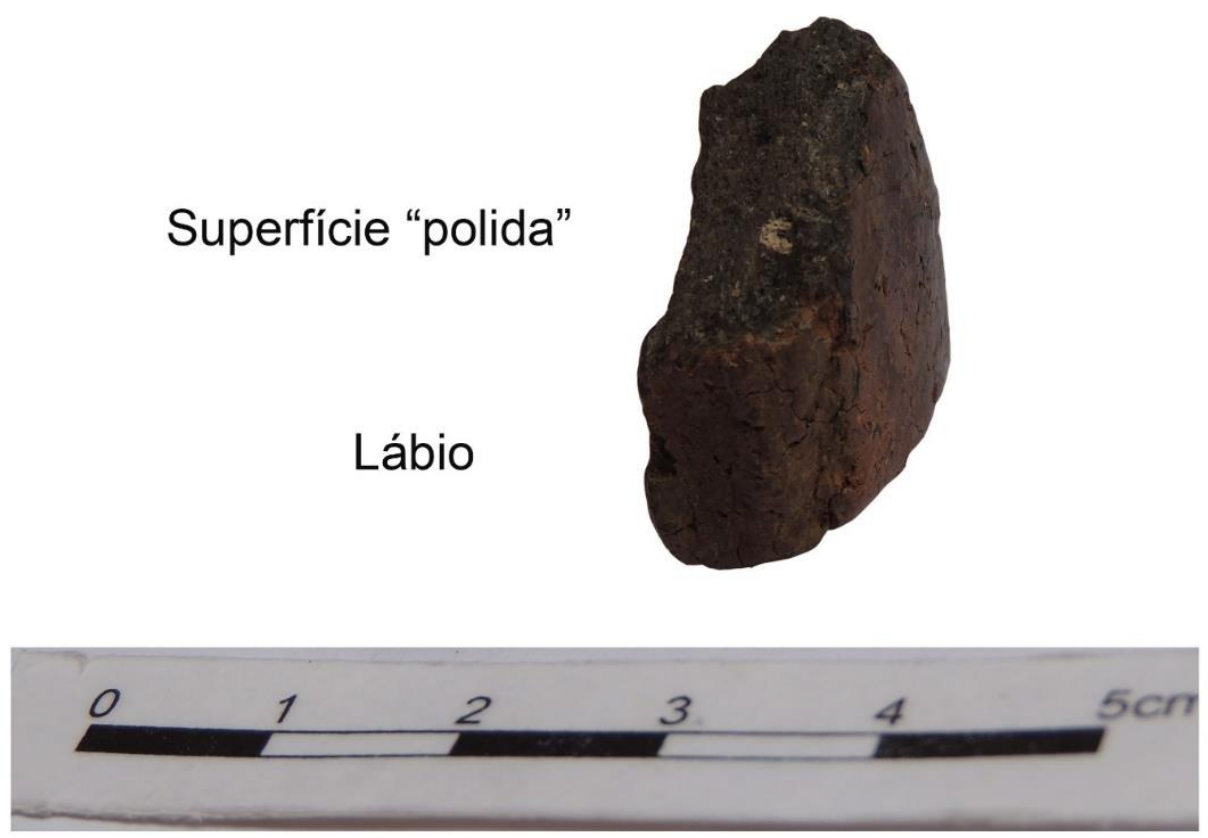

Fonte: Prospecção arqueológica realizada em 02/02/2017. Org. Leal, 2017.

Foto 16 - Indício de "banho e de queima"

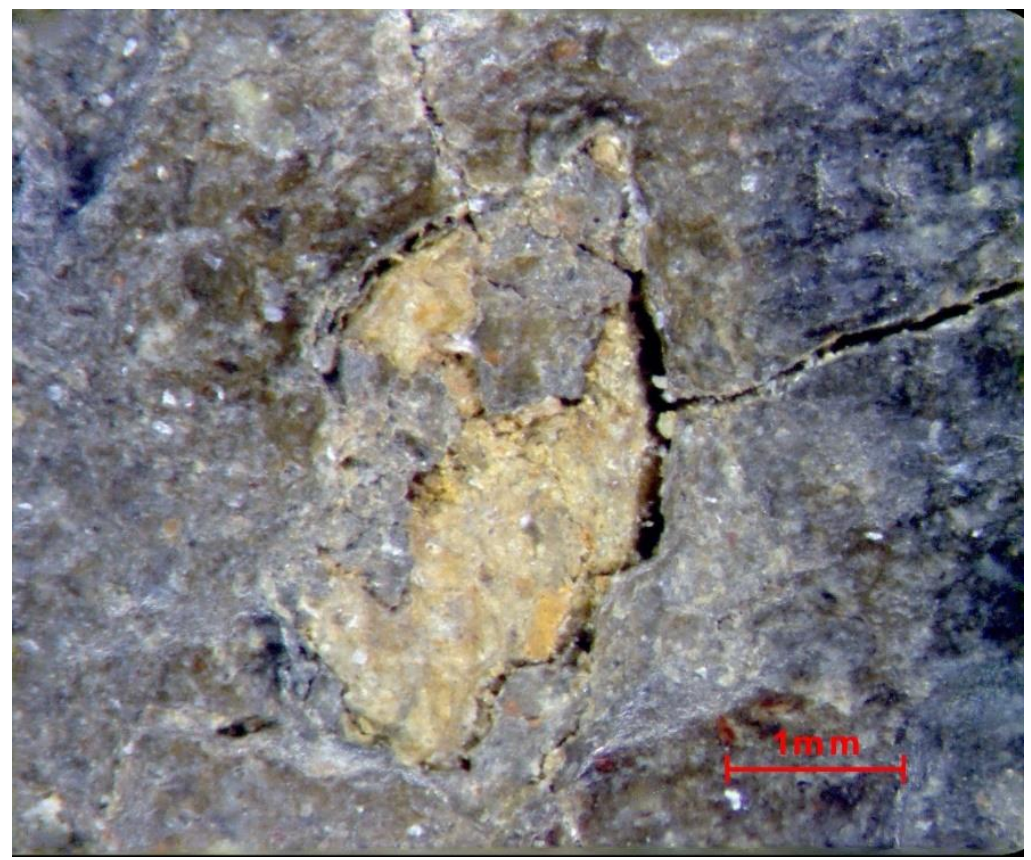

Fonte: Prospecção arqueológica realizada em 02/02/2017. Org. Leal (2017). 
Foto 17 - Quartzo sacaroide

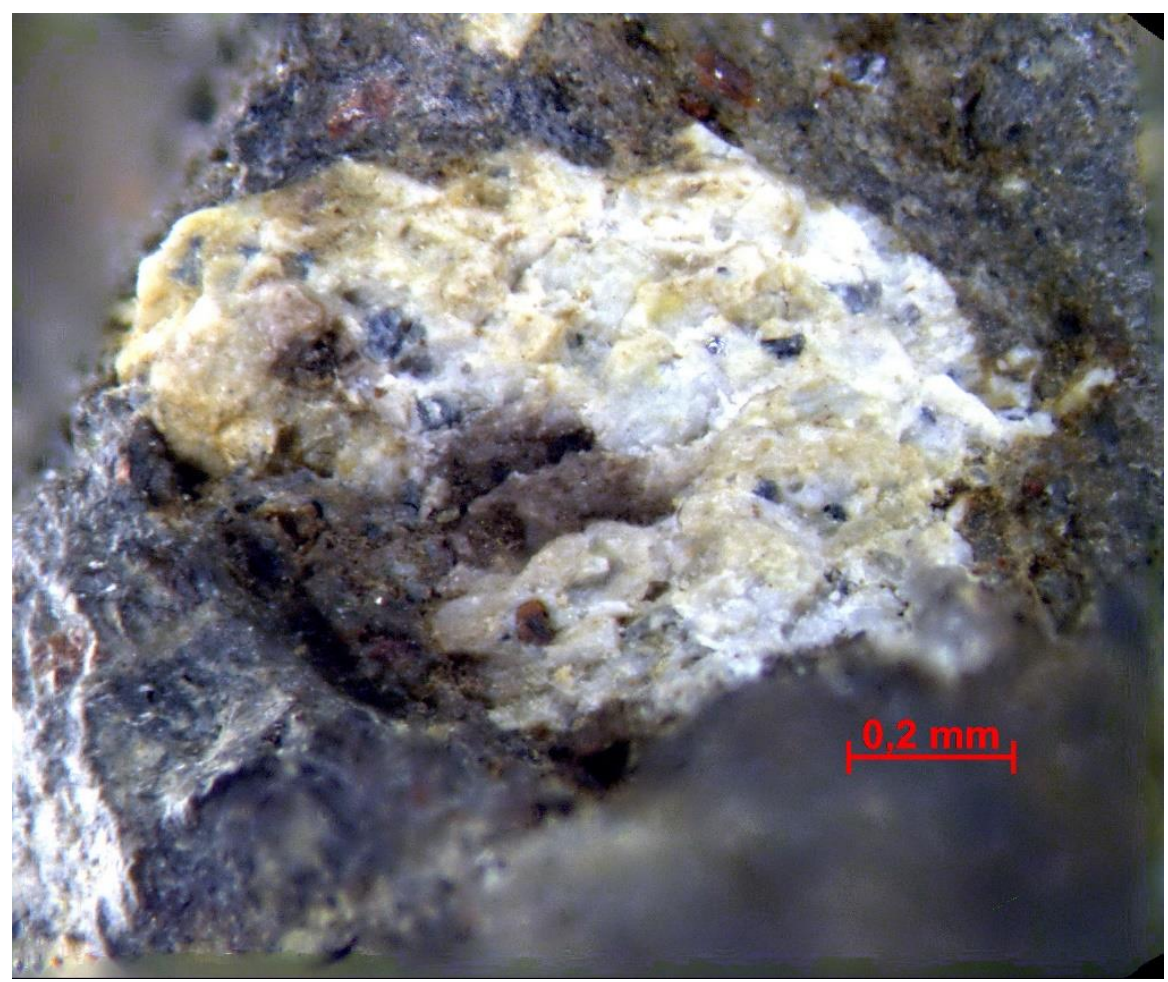

Fonte: Prospecção arqueológica realizada em 02/02/2017. Org. Leal (2017).

Foto 18 - Camada sobre a massa (banho)

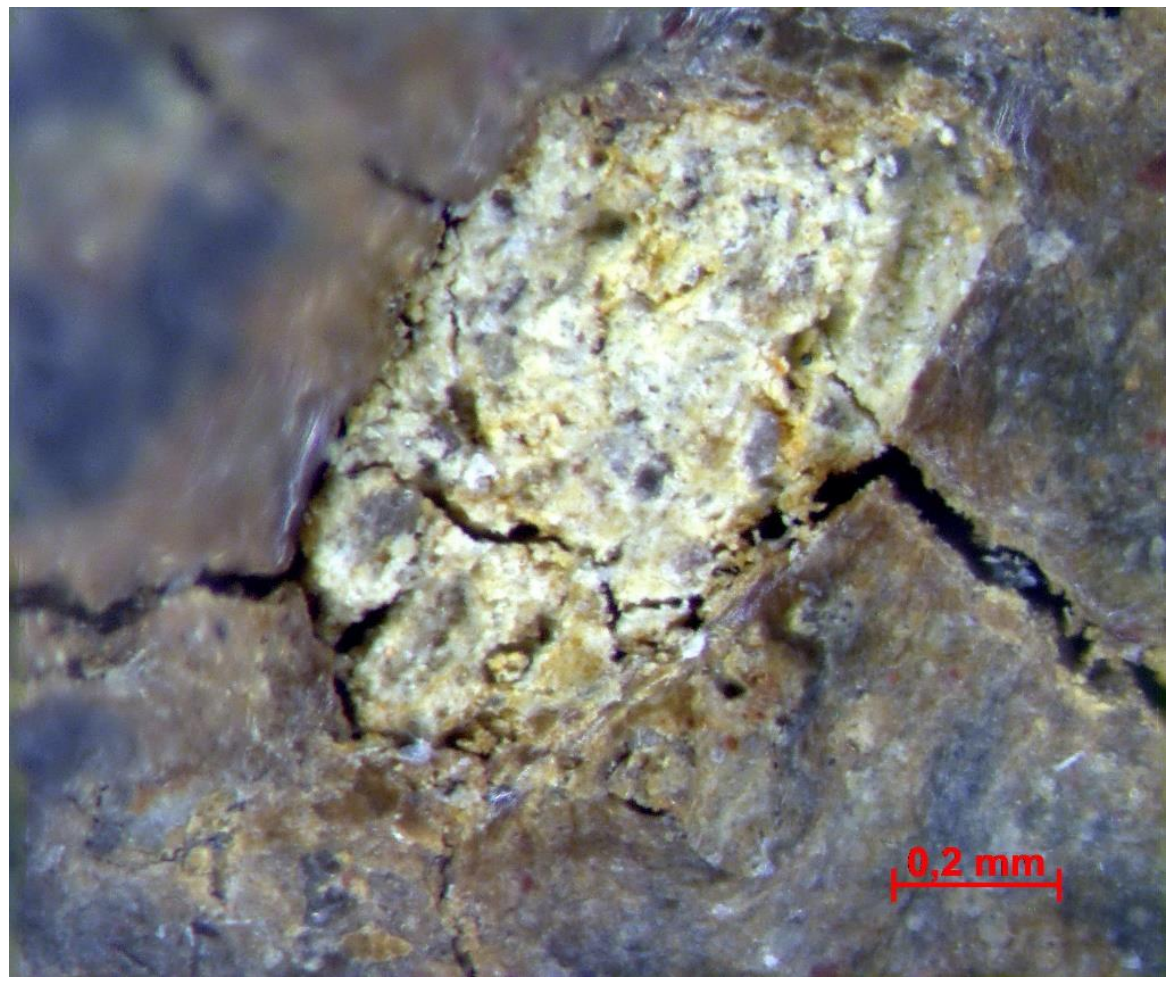

Fonte: Prospecção arqueológica realizada em 02/02/2017. Org. Leal (2017). 
Tanto na face interna, como na externa do material (vide foto 19), nota-se a presença de fraturas.

Foto 19 - Fraturas sobre a superfície da cerâmica

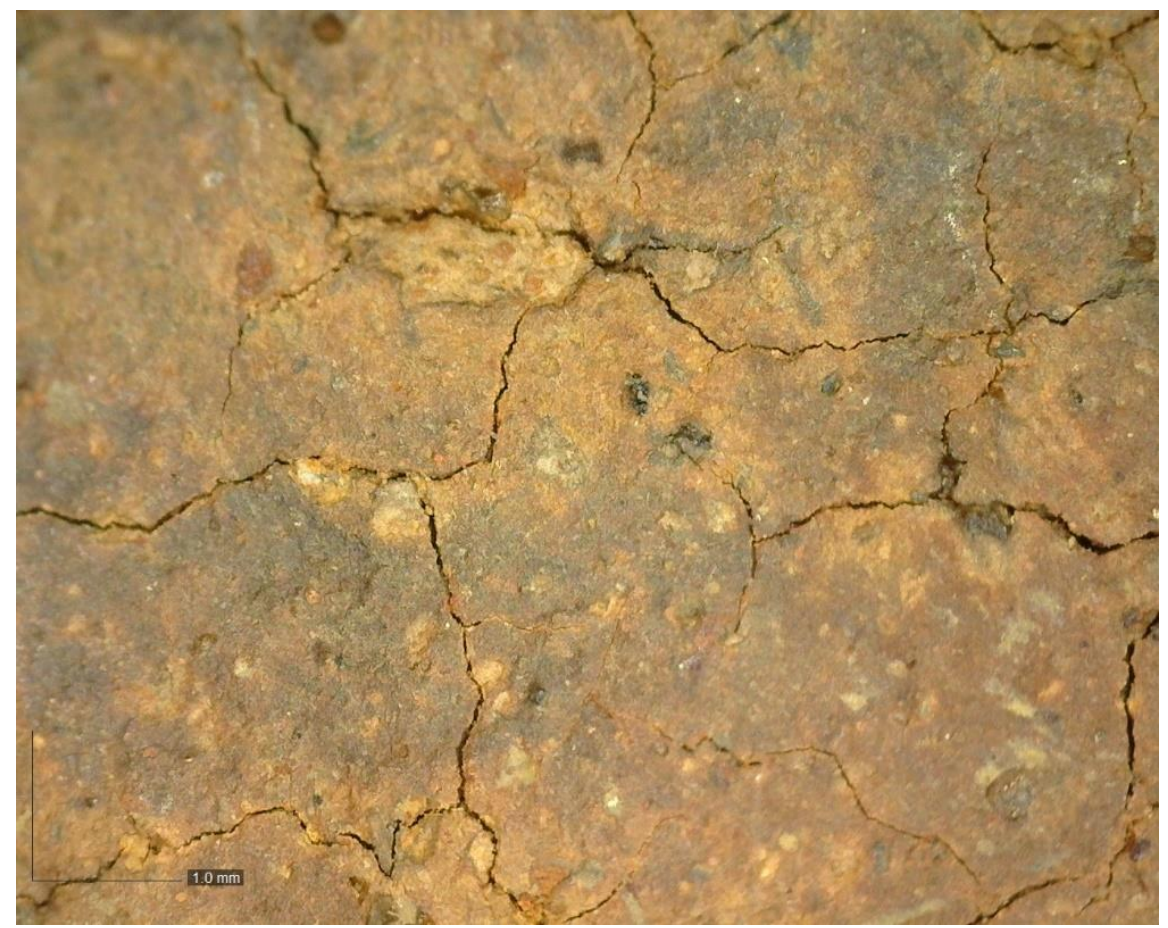

Fonte: Prospecção arqueológica realizada em 02/02/2017. Org. Leal (2017).

As fraturas da cerâmica são semelhantes as estruturas conhecidas por gretas de contração, recorrentes da retração causada pelo calor, conforme demonstrado na foto. O único fragmento encontrado não nos permite associá-lo, de maneira confiável a alguma tradição arqueológica. Ao compará-lo com outras amostras de cerâmica já encontradas na região, nota-se alguma semelhança com a produzida por povos relacionados a tradição Aratu.

Espera-se que a continuidade da pesquisa na área, com viabilidade financeira para realizar mais prospecções, possa trazer mais informações sobre o material encontrado.

\subsection{ANÁLISE DA ESPACIALIZAÇÃO DOS DADOS}

Após a finalização da análise dos materiais encontrados em campo, os locais de prospecção foram plotados no mapa 2 de potencial arqueológico (vide 
anexo) e foram usadas algumas ferramentas do Arcgis para auxiliar na avaliação dos resultados. Foram medidas distancias entre as sondagens positivas e a drenagem, visível na carta topográfica de 1:10.000, mais próxima, bem como a distância entre as tradagens. Os recortes das áreas, representados nas figuras 13, 14 e 17, em escala maior, viabilizaram esse tipo de análise.

A criação de um "Buffer", sobre o curso do rio Paraíba (vide mapa 1) possibilitou conhecer a distância média entre ele e o conjunto de depressões mais próximo dele. O rio está a mais de 100 metros dessas feições.

Ao se observar a localização das depressões, sobre o interflúvio, algumas a uma grande distância do principal canal de drenagem da região, o Rio Paraíba do Sul, poderíamos inferir que a presença delas poderia supriria as necessidades dos povos pretéritos por água, alimento e matéria-prima para confecção de artefatos (argila por exemplo). Acreditamos que as depressões pequenas, quando próximas umas das outras, poderiam se tornar grandes áreas alagadas em períodos chuvosos, tendo o mesmo efeito que uma depressão grande e isolada em termos de recursos.

Os mapas de potencial arqueológico 1 e 2 (vide anexos) mostram que das três áreas prospectadas, em duas, apareceu material arqueológico: colina 12 e Depressão D1. Porém, para saber se o mesmo acontecerá nos demais locais apontados como de maior potencial arqueológico, sugere-se a continuidade dos estudos na região aqui abordada.

Como os limites entre os terraços mais altos do rio Paraíba do Sul e os interflúvios não foram bem definidos, mas apenas indicados pelas diferenças das cotas altimétricas, o conjunto das duas áreas representa uma zona de maior potencial arqueológico, pois concentra a maior parte das depressões, de modo que as camadas correspondentes a essas feições se sobrepuseram no mapa final. 


\section{CONSIDERAÇÕES FINAIS}

O limite da depressão, obtido pelo emprego da estereoscopia e, depois, pelo uso do Arcgis, mostra também o limite do interflúvio. No caso de D1, foram feitas quatro sondagens, a partir da linha d'água, subindo a vertente, a cada trinta metros. E depois, mais quatro no sentido contrário. $O$ fragmento de cerâmica foi achado próximo à área mais alta, porém em local onde o terreno já tendia a descer. $O$ fato de não estar na área inundável da depressão, talvez indique que os grupos humanos que o produziram, já tivessem conhecimento desse limite e evitassem se estabelecer em locais onde a água pudesse invadir em ocasiões de cheias excepcionais.

Uma possível explicação para a profundidade de três metros, na qual a cerâmica foi achada pode estar relacionada a processos de coluvionamento.

Embora Xavier e Coelho Neto (2008) tenham apontado a vertente da Serra da Mantiqueira como local de maior concentração das depressões, no trecho apresentado em nosso mapa de potencial arqueológico, essas feições estão em maior número e tamanho na vertente da Serra do Mar.

Mesmo que não tenha sido um objetivo, considera-se que o desenvolvimento dessa pesquisa gerou um modelo de localização de material arqueológico, relacionado a sítios pré-coloniais, semelhante, sob alguns aspectos, aos modelos preditivos discutidos em projetos de pesquisa arqueológica para fins de licenciamento ambiental.

Os produtos cartográficos gerados poderão servir de auxílio para outras pesquisas na região, pois agregam dados relativos a aspectos do relevo que são uteis a outras áreas do conhecimento.

A geoarqueologia mostrou-se uma abordagem adequada a realização de estudos que cruzam dados físicos para fazer inferências sobre os locais preferenciais ao assentamento humano de grupos pré-coloniais.

Técnicas de prospecção de subsuperfície, a partir de malhas triangulares e a profundidades maiores que 150 centímetros, comumente alcançadas por cavadeiras boco de lobo, se mostraram eficientes em contextos de ambientes tropicais, nos quais processo de deposição (movimentação de massa) e erosivos ocorrem de forma diferenciada e as taxas de coluvionamento são maiores. 
O encontro de material arqueológico nas áreas prospectadas, a partir da elaboração do mapa preliminar - mapa 1 de potencial arqueológico, representado por um fragmento de cerâmica, localizado próximo a uma grande depressão e por dez amostras de material lítico (fragmentos de lascas e lascas), coletados em área de morro, confirmou a hipótese dessa pesquisa.

A amostra reduzida de artefatos, em quantidade e em tamanho, não permitiu relacioná-los às tradições arqueológicas já estudadas na região, bem como as limitações de tempo e de financiamento inviabilizaram outras etapas de campo para a exploração dos arredores das áreas prospectadas. Supõe-se que o levantamento futuro de outros dados poderão ajudar a confirmar se as marcas nas paredes do abrigo pequeno tratam-se mesmo de arte rupestre. De qualquer forma, a proximidade dele com a área na qual foram encontradas as lascas já constitui um indicativo de contexto de sítio arqueológico.

Como o mapa 2 de potencial arqueológico apresentado, mostra uma ampla zona de pontos considerados como de potencial arqueológico (conjunto de depressões menores, porém próximas, depressões grandes mais isoladas, concentras nos interflúvios e áreas de morros e colinas terciárias), e neste estudo, só foram investigadas em campo, três áreas, sugere-se a continuidade dos estudos arqueológicos, afim de avaliar a real eficiência do modelo proposto. 


\section{REFERÊNCIAS}

AB'SABER, Aziz Nacib. Um conceito de geomorfologia a serviço das pesquisas sobre o quaternário. Geomorfologia, São Paulo, n. 18, 1969.

ABREU, W. B. Pindamonhangaba: tempo e face. Aparecida: Santuário, 1977. AFONSO, M. C. Geoarqueologia em ambientes costeiros: o papel da água no registro arqueológico e na paisagem. In. RUBIN, J. C. R.; SILVA, R. T. (Org.). Geoarqueologia: teoria e prática. Goiânia: Editora da UCG, 2008. p.95-106. A LASCA CONSULTORIA E ACESSORIA EM ARQUEOLOGIA. Relatório de resgate. Resgate científico do patrimônio cultural arqueológico - "Loteamento AlphaVille - São José dos Campos”, município de São José dos Campos - SP. São Paulo, 2011.

Relatório de campo da terceira fase de resgate arqueológico do sítio

Carcará. Programa de resgate científico do patrimônio cultural arqueológico Loteamento Alphaville, município de São José dos Campos, SP. São Paulo, 2012. ANDRADE, A. C. A. Arqueologia em Taubaté e no Vale do Paraíba. Boletim Histórico Cultural, Taubaté, v. 2, n.19, maio 1997.

ANDREATTA et al. Projeto Fazenda São Sebastião do Ribeirão Grande: preservação de seu patrimônio natural e cultural. Relatório de atividades de educação patrimonial e ambiental desenvolvidas em 2012 e 2013. São Paulo: A \& T Pesquisas Arqueológicas. 2014.

AGENCIA DA BACIA DO RIO PARAÍBA DO SUL - AGEVAP. Localização. In.

. Ecossistemas Aquáticos e Ecossistemas Terrestres - P3 - Diagnóstico ambiental (caracterização) - Avaliação Ambiental Integrada - AAI das bacias dos rios Muriaé, Pomba, Piabanha, Paraibuna e Preto, afluentes do rio Paraíba do Sul. 2013. pp.6-7. Disponível em <http://54.94.199.16:8080/publicacoesArquivos/ceivap_pubMidia_Processo_0092011_P03.4.5-EAR.pdf>. Acesso em: 10 jan. 2017.

AGÊNCIA NACIONAL DE ÁGUAS - ANA. Estudos auxiliares para a gestão do risco de inundações Bacia do Rio Paraíba do Sul. Dados da Bacia. 2017.

Disponível em: <http://gripbsul.ana.gov.br/ABacia.html>. Acesso em: 20 set. 2017. ARAUJO, A. G. M. As Geociências e suas implicações em teoria e métodos arqueológicos. Revista do Museu de Arqueologia e Etnologia, 3, 35-45, 1999. 
. Teoria e método em arqueologia regional: um estudo de caso no Alto Paranapanema, estado de São Paulo. 2001. Tese (Doutorado em Arqueologia) Museu de Arqueologia da USP, Universidade de São Paulo, São Paulo, 2001.

. A tradição cerâmica Itararé-Taquara: características, área de ocorrência e algumas hipóteses sobre a expansão dos grupos Jê no sudeste do Brasil. Revista de Arqueologia, 20: 09-38, 2007.

. A ocupação Paleoíndia no estado de São Paulo: uma abordagem geoarqueológica. São Paulo: MAE-USP, 2012. 232 p. Relatório final de atividades do projeto FAPESP/2009/54720-9.

\section{. Geomorfologia e Paleoambientes no leste da América do Sul:}

implicações arqueológicas. In: RUBIN, J. C. R.; SILVA, R. T. (Org.). Geoarqueologia. Goiás: Editora da PUC, 2013. p.135-180.

. On Vastness and Variability: Cultural Transmission, Historicity, and the Paleoindian Record in Eastern South America. Anais da Academia Brasileira de Ciências, v. 87, p.1.239-1.258, 2015.

ARAUJO, A. G. M.; CORREA, L. First notice of a Paleoindian site in central São Paulo State, Brazil: Bastos site, Dourado County. Palaeoindian Archaeology, v. 1, n. 1, p.4-14, 2016.

ARAUJO, A. G. M.; NEVES, W. A. A Ocupação Paleoíndia do Sudeste Brasileiro: Lagoa Santa e Além. In: MORALES, W. F.; MOI, F. P. (Org.). Tempos Ancestrais. São Paulo: Annablume, 2012, p. 47-71.

ARAUJO et al. Paleoindian Open-Air Sites in Tropical Settings: a Case Study in Formation Processes, Dating Methods, and Paleoenvironmental Models in Central do Brazil. Geoachaeology: An Internacional Journal, n. 28, p.195-220, 2013. . The "Lagoa do Camargo 1" Paleoindian site: some implications for tropical geomorphology, pedology, and paleoenvironments in southeastern Brazil.

Geoarchaeology, n. 32, p.662-677, 2017.

ARGENTO, M. S. F. Mapeamento geomorfológico. In. GUERRA, A. J. T; CUNHA, S. B. da. (Org.) Geomorfologia: uma atualização de bases e conceitos. 9 ed. Rio de Janeiro: Bertrand Brasil, 2009, p.365-391.

ASSUNÇÃO, D. C.; BELEM, F. R.; JULIANI, L. J. C. O.; O Sítio Lítico Carcará de São José dos Campo, SP: escavação e análise laboratorial de um sítio de 
caçadores-coletores no Vale do Paraíba do Sul. Revista do Museu de Arqueologia e Etnologia, São Paulo, Suplemento, n. 11, p.83-88, 2011.

BARIONI, A. O Uso dos Sistemas de Informações Geográficas para Identificação de Áreas de Potencial Arqueológico no Complexo Hidrelétrico de Belo Monte. 2011. Trabalho de Graduação. Faculdade de Filosofia, Letras e Ciência Humanas, Universidade de São Paulo. 2013.

BINFORD, L. Man the mighty hunter? In: . In Pursuit of the Past: Decodifing the Archaeological Record. Thames \& Hudson, 1983a, p.33-59.

. Working at Archaeology. New York, Academic Press. 1983b.

BITENCOURT, A. L. V. Princípios e métodos e algumas aplicações da geoarqueologia. In: RUBIN, J. C. R.; SILVA, R. T. (Org.). Geoarqueologia: teoria e prática. Goiânia: Editora da UCG, 2008. p.44-70.

BORNAL, W. G. Introdução. In. ROBRAHN-GONZÁLEZ; E. M.; ZANETTINI, P. E. Jacareí às vésperas do descobrimento: a pesquisa arqueológica no sítio Santa Marina. São Carlos: Gráfica e Editora O Expresso, 1999. p.2-13.

BROWN, A.G. Alluvial geoarchaeology: floodplain archaeology and environmental change. Cambridge: Cambridge University Press, 2001. 377p.

BUENO, L.; DIAS, A. S.; STEELE, J. The Late Pleistocene/Early Holocene archaeological record in Brazil: a geo-referenced database. Quaternary International, n. 301, p.74-93, 2013.

CALDARELLI, S. B. Arqueologia do interior paulista evidenciada por suas rodovias. Revista de Arqueologia. V. 14-15, p. 29-55, 2001-2002.

CALDARELLI, S. B. Arqueologia do Vale do Paraíba Paulista: SP-070 Rodovia Carvalho Pinto. Instituto de Pesquisa em Arqueologia; Universidade Católica de Santos, 2003.

CALI, P. Sítio Arqueológico Rio Comprido I e seu contexto no Vale do Paraíba. Editora Monte Arte. 1999

CAMARGO, C. B. R.; CAMARGO, V. Arqueologia no Vale do Paraíba - Escavações Arqueológicas em Aparecida. Cadernos Culturais do Vale do Paraíba, 5, Caçapava, Centro Educacional Objetivo/Fundação Nacional do Tropeirismo, 1990. CAMPOS, R. C. Determinação da cor do solo e sua utilização na predição dos teores de hematita. 2001. Dissertação (Mestrado em Agronomia). Escola Superior de Agricultura Luiz de Queiroz. Universidade de São Paulo. 2016. 
CARVALHO, A. M. A.; VIDAL, A. C. \& KIANG, C. H. 2011. Delimitação do embasamento da Bacia de Taubaté. Geologia USP. Série Científica. n.11, v.1, p.1932, 2011.

CARVALHO, A. et al. $\mathbf{O}$ que é metodologia científica. In. Aprendendo Metodologia Científica. São Paulo: O nome da Rosa, 2000, p.11-69.

CASTRO, C. de M. Um roteiro de pesquisa. In: A prática da pesquisa. São Paulo: Ed. McGraw-Hill do Brasil, 1978. p.113-119.

COLTRINARI, L. Z. D. Contribuição a geomorfologia da região de Guaratinguetá - Aparecida. 1975. Tese (Doutorado em Geografia Física) - Faculdade de Filosofia, Letras e Ciências Humanas, Universidade de São Paulo, São Paulo, 1975.

. Geomorfologia, geoarqueologia e mudanças globais. In.: RUBIN, J. C. R.; SILVA, R. T. (Org.). Geoarqueologia: teoria e prática. Goiânia: Editora da UCG, 2008. p.15-21.

COSTA, R. K. R.; BALLESTERO, S. D. Recuperação de áreas impactadas pela extração de areia tipo cava na região do médio Vale do Paraíba. 2004.

Monografia (Bacharelado em Geografia) - Departamento de Ciências Sociais e Letras, Universidade de Taubaté, Taubaté, 2004.

CHRISTOFOLETTI, A. Geomorfologia fluvial. São Paulo: Edgard Blucher, 1981. 313p.

DANCEY, W. S. The archaeological survey: a reorientation. Man in the Northeast. n 8, 1974, p.98-112.

DUNNELL, R. C. Classificação em Arqueologia. Tradução de Astolfo Gomes de Mello Araujo. São Paulo: EDUSP, 2007. 264p.

DUNNELL, R.C.; DANCEY W.S. The siteless survey: a regional scale data collection strategy. Advances in Archaeological Method and Theory, v.6, p. 267-287, 1983. DUPAS, G. Conhecimento e progresso como verdade. In. O mito do progresso ou progresso como ideologia. 2006. São Paulo, Ed. Da Unesp, p.91-129. ECO, U. A escolha do tema. In: . Como se faz uma tese. São Paulo:

Perspectiva, 1983. p.7-34.

FERREIRA, C. C. Pindamonhangaba: atlas histórico e geográfico. São Paulo: Noovha América, 2007. 
FIGUTI, L.; PLENS, C. R.; DEBLASI, P. Small Sambaquis and Big Chronologies: Shellmound Building and Hunter-Gatherers in Neotropical Highlands. Radiocarbon, Arizona, v. 55, n. 2-3, p. 1.215-1221, 2013.

FILIZOLA, H. F. O papel da erosão geoquímica na evolução do modelado da bacia de Taubaté - SP. 1993. Tese (Doutorado em Geografia Física) - Faculdade de Filosofia, Letras e Ciências Humanas, Universidade de São Paulo, São Paulo, 1993.

FLORENZANO, T. G. (Org.). Geomorfologia: conceitos e tecnologias atuais. São Paulo: Oficina de textos, 2008.

. Introdução à Geomorfologia. In: FLORENZANO, T. G. (Org.).

Geomorfologia: conceitos e tecnologias atuais. São Paulo: Oficina de textos, 2008. FOLEY, R. Off-site archaeology: an alternative approach for the short-sited. In: I. HODDER; G. ISAAC \& N. HAMMOND - Pattern of the Past - Studies in Honour of David Clarke. Cambridge: Cambridge University Press, 1981.

GARCIA, M. J. et al. A Holocene vegetation and climate record from the Atlantic rainforest belt of coastal State of São Paulo, SE Brazil. Review of Palaeobotany and Palynology, v.131, p.181-199, 2004.

GASPAR, M. D.; BARBOSA, M.; CORDEIRO, J. Arqueologia dos Vales dos rios Paraíba do Sul e Guandu. 2007. Rio de Janeiro: Museu Nacional.

GOOGLE EARTH. Pindamonhangaba. Pindamonhangaba. 1 imagem de satélite. 103Kb. [Satélite?]: SE. 05 ago. 2013. Disponível em: <www.googleearth.com>. Acesso em: 02 abr. 2014.

. Pindamonhangaba. Pindamonhangaba. 1 imagem de satélite. $2078 \mathrm{~Kb}$.

[Satélite?]: SE. 28 dez. 2015. Disponível em: <www.googleearth.com>. Acesso em: 28 dez. 2015.

GOLDBERG, P. Raising the bar: making geological and archaeological data more meaningful for understanding the archaeological record. In. SULLIVAN, A. P. Archaeological concepts for the study of the cultural past. The University of Utah Press. 2008. p.24-39.

GUERRA, A. T.; GUERRA, A. J. T. Novo dicionário geológico-geomorfológico. 6. ed. Rio de Janeiro: Bertrand Brasil, 2008.

GUERRA, A. J. T.; CUNHA, S. B. da. (Org.) Geomorfologia: uma atualização de bases e conceito. 9 ed. Rio de Janeiro: Bertrand Brasil, 2009. 


\section{INSTITUTO FLORESTAL DO ESTADO DE SÃO PAULO. Mapa florestal dos} municípios do estado de São Paulo - Pindamonhangaba. Disponível em: $<$ http://s.ambiente.sp.gov.br/sifesp/pindamonhangaba.pdf>. Acesso em: 10 set. 2017.

IPHAN - Instituto do Patrimônio Histórico e Artístico Nacional. Disponível em: < http://portal.jphan.gov.br/portal/montaPaginaSGPA.do>. Acesso em: 30 de jun. 2014. 2017.

INSTITUTO BRASILEIRO DE GEOGRAFIA E ESTATÍSTICA - IBGE. Região Sudeste do Brasil: Pindamonhangaba. [S.I], 1988. 1 mapa, color. Escala 1:50.000. Disponível em: <http://loja.ibge.gov.br/cartas-mapas-e-cartogramas/mapeamentotopografico.html>. Acesso em: 20 fev 2014.

INSTITUTO BRASILEIRO DE GEOGRAFIA E ESTATÍSTICA - IBGE. Região Sudeste do Brasil: Pindamonhangaba. [S.I], 1987. 1 mapa, color. Escala 1:10.000. . Manual Técnico de Pedologia. Coordenação de Recursos Naturais e Estudos Ambientais. 3. Ed. 2015. 430p. Manuais técnicos em geociências. INSTITUTO AGRONÔMICO DE CAMPINAS - IAC. Mapa pedológico do estado de São Paulo. Campinas: IAC/Embrapa, 1999. Escala 1:500.000. INSTITUTO DE PESQUISAS TECNOLÓGICAS DO ESTADO DE SÃO PAULO IPT. Carta Geológica do Estado de São Paulo - Pindamonhangaba (23-Y-B-VI-3). São Paulo: Pró-Minério, 1990. 1 mapa, $90 \mathrm{~cm}$ x $60 \mathrm{~cm}$. Escala 1:50.000. KASHIMOTO, E. M.; SALLUN, A. E. M.; SUGUIO, K. Geoarqueologia de ambientes fluviais: o Alto Paraná. In: RUBIN, J. C. R.; SILVA, R. T. (Org.). Geoarqueologia: teoria e prática. Goiânia: Editora da UCG, 2008. p.109-132. KNEIP, A.; MELLO, A. A. S. Modelos preditivos em arqueologia: desenvolvimento e aplicação em uma região homogênea do Tocantins. In: II CIAEE Congresso Iberoamericano de Arqueologia, Etnologia e Etnohistória, 2012, Dourados. Anais do II CIAEE, 2012 KIPNIS, R. O uso de modelos preditivos para diagnosticar recursos arqueológicos em áreas a serem afetadas por empreendimentos de impacto ambiental. In.: CALDARELLI, S. B. (Org.). Atas do Simpósio sobre Política Nacional do Meio Ambiente e Patrimônio Cultural: Repercussões dos Dez Anos da Resolução CONAMA no 001/86 sobre a Pesquisa e a Gestão dos Recursos Culturais no Brasil. 
Goiânia, Fórum Interdisciplinar para o Avanço da Arqueologia/IGPA-UCG, 1997: 3440.

KERN, D. C.; COSTA, M. L.; RUIVO, M. L. P. Métodos e técnicas geoarqueológicas para caracterização de solos com terra preta na Amazônia: contribuições para a Arqueologia. In: RUBIN, J. C. R.; SILVA, R. T. (Org.). Geoarqueologia: teoria e prática. Goiânia: Editora da UCG, 2008. p.109-132. LAKATOS, E. M.; MARCONI, M. de A. Técnica de pesquisa. In. Fundamentos de metodologia científica. 3 ed. São Paulo: Atlas, 1994. p.174-217. LACEY, H. A forma nas quais as ciências são e não são livres de valores. Tradução de Marcos Rodrigues da Silva. Crítica, Londrina, v.6, n.21, p.89-111, out./dez. 2000. LEAL, S. D. O rio Paraíba do Sul e o desenvolvimento de Pindamonhangaba (SP). SEMANA DE GEOGRAFIA, 24; SEMINÁRIO DE GEOGRAFIA DO NORTE DO PARANÁ, 3., 2008, Londrina. Anais... Londrina: UEL, 2008, p. 1-17. LAMING-EMPERAIRE, A. Guia para o estudo as indústrias líticas da América do Sul. Curitiba: UFPR, 1967. Manuais de Arqueologia 2.

LIMA, T. A. O povoamento inicial do continente americano: migrações, contextos, datações. In: SILVA, H. P.; RODRIGUES-CARVALHO, C. (Org.). Nossa origem: o povoamento das Américas - visões multidisciplinares. Rio de Janeiro: Vieira \& Lent, 2006.

LOPES, M. Ocupação Tupinambá no Vale do Paraíba Paulista: vista a partir da análise do sítio arqueológico Santa Marina. 2014. Dissertação (Mestrado em Arqueologia) - Museu de Arqueologia da USP, Universidade de São Paulo, São Paulo, 2014.

MANCINI, F. Estratigrafia e aspectos da tectônica deformadora da Formação Pindamonhangaba, Bacia de Taubaté, SP. 1995. Dissertação (Mestrado em Geociências) - Instituto de Geociências da USP, Universidade de São Paulo, São Paulo, 1995.

MARANCA, S. Dados preliminares sobre arqueologia do estado de São Paulo. Museu Paraense Emilio Goeldi, Belém, n. 26, p.133-139, 1969. Publicações avulsas.

MARQUES, J. S. Ciência Geomorfológica. In. GUERRA, A. J. T; CUNHA, S. B. da. (Org.) Geomorfologia: uma atualização de bases e conceitos. 9 ed. Rio de Janeiro: Bertrand Brasil, 2009, p. 23-50. 
MATALLO JUNIOR, H. Mito, metafísica, ciência e verdade. In. CARVALHO, M. C. de (Org.). Construindo o saber: fundamentos e técnicas de metodologia científica. 24. ed. São Paulo: Papirus, 2011. p.35-46.

. A problemática do conhecimento. In. CARVALHO, M. C. de (Org.).

Construindo o saber: fundamentos e técnicas de metodologia científica. 24. ed. São Paulo: Papirus, 2011. p.15-33.

MINISTÉRIO DO MEIO AMBIENTE - MMA. Mata Atlântica. 2017. Disponível em: <http://www.mma.gov.br/biomas/mata-atlantica>. Acesso em: 20 out. 2017. MORAIS, A. C. R.; COSTA, U. M. O ponto de partida: o método. In. A valorização do espaço. São Paulo: Hiucitec, 1984. p.26-34.

MORAIS, J. L. A propósito do estudo das indústrias líticas. Revista do Museu Paulista. São Paulo, n. 34, p. 155-184, 1987.

. A Arqueologia e o fator geo. Revista do Museu de Arqueologia e Etnologia, 9:3-22. MAE-USP, 1999.

. Arqueologia da Região Sudeste. Revista do Museu de Arqueologia e Etnologia, 44:194-217. MAE-USP, 1999-2000.

MOURA, C. A. Zoneamento geoambiental como subsídio à análise dos indicadores ambientais nas áreas de dutos: caracterização do clima como fator determinante da instabilidade das áreas de implantação de dutos. 2006. Trabalho de conclusão de curso. Instituto de Geociências e Ciências Exatas do Campus de Rio Claro, Universidade Estadual Paulista. Rio Claro.

NAZARENO, N. R. X. SIG Arqueologia: aplicação em pesquisa arqueológica. 2005. Tese (doutorado em Arqueologia). Museu de Arqueologia e Etnologia. Universidade de São Paulo. 2005.

NEVES, W. A. Origens do homem nas Américas: fósseis versus moléculas? In: SILVA, H. P.; RODRIGUES-CARVALHO, C. (Org.). Nossa origem: o povoamento das Américas - visões multidisciplinares. Rio de Janeiro: Vieira \& Lent, 2006. NOVO, E. M. L. de M. Ambientes fluviais. In. FLORENZANO, T. G. (Org.). Geomorfologia: conceitos e tecnologias atuais. São Paulo: Oficina de textos, 2008. MUSEU HISTÓRICO E PEDAGÓGICO DOM PEDRO I E DONA LEOPOLDINA PINDAMONHANGABA - MUPI. Listagem de Objetos: catálogo.

Pindamonhangaba, 2010. 
OLIVEIRA, J. F.; BARTOLOMUCCI, R.; RODRÍGUEZ, A. C. M. Geoprocessamento e análises espaciais aplicados à arqueologia. Anais do $X$ Encontro de Geógrafos da América Latina - 20 a 26 de março de 2005 - Universidade de São Paulo. OSTAFIUC, G. B. Metodologia para o cálculo de reservas da turfeira de Jacareí e suas características físico-químicas. 1986. Dissertação (mestrado em Geociências) - Instituto de Geociências, Universidade de São Paulo, São Paulo, 1986.

PASIN, J. L. O Vale do Paraíba ontem e hoje. Rio de Janeiro: AC\&M - Assessoria de Comunicação e Marketing, 1988.

. Aspectos históricos do município de Roseira. Ângulo, Lorena, v.55, n. 1. jul/set 1993.

PINDAMONHANGABA, Município de. Plano Municipal de Gestão Integrada de Resíduos Sólidos - etapa II: caracterização municipal. Dez 2016.

RICCOMINI, C. O Rift Continental do Sudeste do Brasil. 1989. Tese (Doutorado em Geociências) - Instituto de Geociências da USP, Universidade de São Paulo, São Paulo, 1989.

ROBRAHN-GONZÁLEZ; E. M.; ZANETTINI, P. E. Jacareí às vésperas do descobrimento: a pesquisa arqueológica no sítio Santa Marina. São Carlos: Gráfica e Editora O Expresso, 1999.

ROSS, J. L. S. Geomorfologia: ambiente e planejamento - Repensando a Geografia. 7 ed. São Paulo: Contexto, 2003.

ROSS, J. L. S.; MOROZ, I. C. Mapa Geomorfológico do Estado de São Paulo. Laboratório de Geomorfologia, Departamento de Geografia - FFLCH - UPS / Laboratório de Cartografia Geotécnica - Geologia Aplicada - IPT / FAPESP Fundação de Amparo à Pesquisa do Estado de São Paulo - Mapas e Relatório, São Paulo. 1997.

RUBIN, J. C. R.; SILVA, R. T. (Org.). Geoarqueologia: teoria e prática. Goiânia: Editora da UCG, 2008, $171 \mathrm{p}$.

. Geoarqueologia. Goiânia: Editora da UCG, 2013, 268 p.

SAINT-EXUPÉRY, A. O pequeno príncipe. Com aquarelas do autor. 48. ed. Tradução de Dom Marcos Barbosa. Rio de Janeiro: Agir, 2009. SAMPIERI, R. H.; COLLADO, C. F.; LUCIO, M. del P. B. Definição dos enfoques quantitativo e qualitativo, suas semelhanças e diferenças. In. 
Metodologia de pesquisa. Tradução de Daisy Vaz de Moraes. Porto Alegre: Penso, 2013.

SANTIAGO, P. C.; TEIXEIRA, J. E. J.; TRONCHINI, K. F. C. Rio Paraíba do Sul: degradação ambiental provocada pela mineração de areia. 1999. Trabalho de Conclusão de Curso - Fundação Armando Álvares Penteado, São José dos Campos.

SANTORO, E; ENS, H. H.; NAGATA, N. Geologia das folhas Jacareí, Tremembé, Taubaté e Pindamonhangaba-SP. Parte 1: embasamento setentrional da Bacia de Taubaté. In.: SIMPÓSIO DE GEOLOGIA DO SUDESTE, 2., 1991, São Paulo. Atas... São Paulo, Sociedade Brasileira de Geologia - Núcleos de São Paulo e Rio de Janeiro, 1991, p.481-489.

SANTOS, A. R. dos. A tectônica e as formas de relevo. In. FLORENZANO, T. G. (Org.). Geomorfologia: conceitos e tecnologias atuais. São Paulo: Oficina de textos, 2008.

SANTOS NETO, J. R. Extração de areia: suas normas legais e alterações ambientais. Estudo de caso: o Vale do Paraíba - Trecho de Taubaté à Pindamonhangaba - SP. 2004. Monografia (Bacharelado em Geografia) Departamento de Ciências Sociais e Letras, Universidade de Taubaté, Taubaté, 2004.

SANTOS, R. E. F.; SENA, P. S. Base Territorial da Mata Atlântica. Etno-ecologia da Argila Branca na Tribo Tupiguarani (Séculos XIV e XV). Janus, Lorena, n. 11, Jan./Jun., 2010. p.

SÃO PAULO (Estado). Secretaria de Saneamento e Recursos Hídricos. Sistema integrado de gerenciamento de recursos hídricos do Estado de São Paulo (SIGRH). Disponível em: <http://www.sigrh.sp.gov.br/cbhps/apresentacao>. Acesso em: 10 out. 2017.

SCHEUER, H. L. Quatro campos escavados em diversos lugares. Aparecida: relatório não publicado, jul.1957.

SECRETARIA DE AGRICULTURA DO ESTADO DE SÃO PAULO - INTITUTO AGRONOMICO. Aerofoto Natividade Ltda. Foto aérea. São Paulo, 1962. 1 fotografia aérea. Escala 1:25.000. Números: 6522; 6525; 6568; 6570; 6577; 6582; 6586; 6633; $6635 ; 6637 ; 6639 ; 6652 ; 6706 ; 6707 ; 6709 ; 6715 ; 6803$ e 6806 . 
SILVA, K. S.; ROSA, J. H.; LUZ, R. A.; Carta de sensibilidade arqueológica: breve introdução aos estudos de padrões de assentamento de populações pré-coloniais na UHE Jirau - Rondônia, Brasil. Revista de Geografia. Recife: UFPE - DCG/NAPA, v. especial VIII SINAGEO, n. 2, Set. 2010.

SILVA, A. C. da. Da investigação a interpretação. In: . O espaço torna do lugar. São Paulo: Hiucitec, 1978.

SPÓSITO, E. S. A questão do método e a crítica do conhecimento. In: Geografia e filosofia: contribuição para o ensino do pensamento geográfico. São Paulo: UNESP, 2004. p.23-65.

STRAHLER, A. N. Quantitative analysis of watershed geomorphology. New Halen: Transactions: American Geophysical Union, v. 38. P. 913-920. 1957. SUGUIO, K. Contribuição à geologia da Bacia de Taubaté: Vale do Paraíba estado de São Paulo. 1969. Tese (Doutorado em Geologia) - Faculdade de Filosofia, Letras e Ciências Humanas, Universidade de São Paulo, São Paulo, 1969.

Dicionário de Geologia Sedimentar e áreas afins. Rio de Janeiro: Bertrand-Brasil, 1998.

. Geologia Sedimentar. São Paulo: Blucher, 2003.

THOMAZ, R. C. C. O uso de SIG na predição da localização de sítios arqueológicos: um estudo de caso na bacia do Paraná Superior. 2002. Tese (doutorado em Arqueologia). Faculdade de Filosofia, Letras e Ciência Humanas, Universidade de São Paulo. 2002.

TRICART, J. Principes et méthodes de I geomorfologie. Paris: Masson Ed., 1965.

TRIGGER, B. The future of Archaeology is The Past. In: . Time and Traditions: Essays in Archaeology Interpretatation. Columbia University Press, 1978. p.37-52.

TRONCOSO; L. P. S.; CORRÊA, A. A.; ZANETTINI, P. E. Paleoíndios em São Paulo: nota a respeito do sítio Caetetuba, município de São Manuel, SP.

Palaeoindian Archaeology, v. 1, n. 1, p.50-71, 2016.

XAVIER, F. A.; COELHO NETO, A. L. Ocorrência de Depressões Fechadas em Divisores de Drenagem no Médio Vale do Rio Paraíba do Sul. Geografias. Artigos científicos. Belo Horizonte: n. 4, v. 1, p. 61-68, jul./dez. 2008. ZANETTINI, P. E. Sítios em Pindamonhangaba. Mensagem recebida por diretoria@zanettiniarqueologia.com.br em 30 out. 2017. 
ANEXOS 
PERFIS TOPOGRÁFICOS DE PINDAMONHANGABA-SP
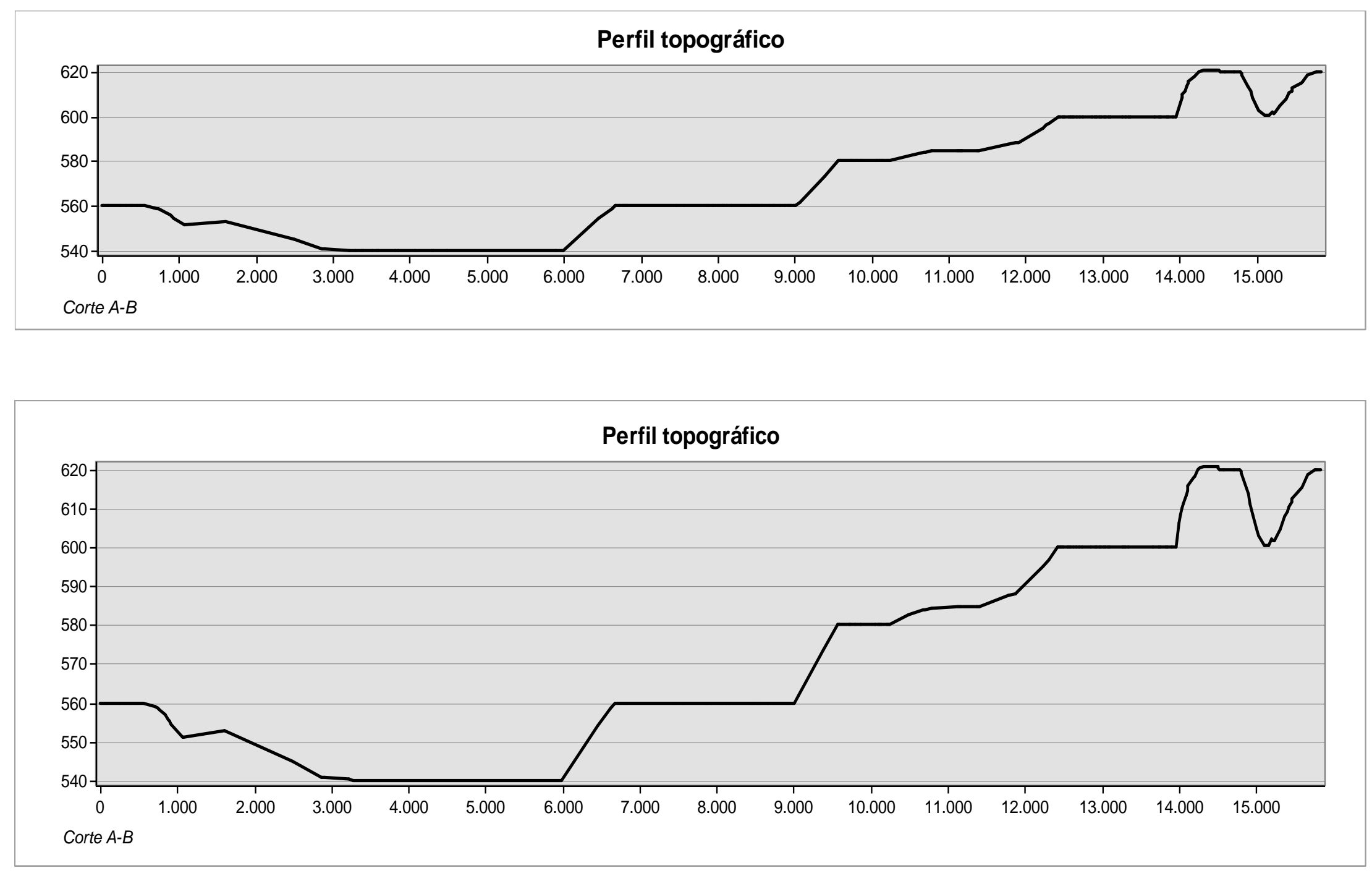


\section{+ Carta hipsométrica - Pindamonhangaba}

\section{Legenda}

\begin{tabular}{l}
\hline Curvas \\
Hidrografia \\
Hipsometria \\
Edge type \\
\hline Hard Edge \\
\hline Elevation \\
$680-1680$ \\
$660-680$ \\
$640-660$ \\
$620-640$ \\
$600-620$ \\
$580-600$ \\
$560-580$ \\
$540-560$ \\
540 \\
\hline
\end{tabular}

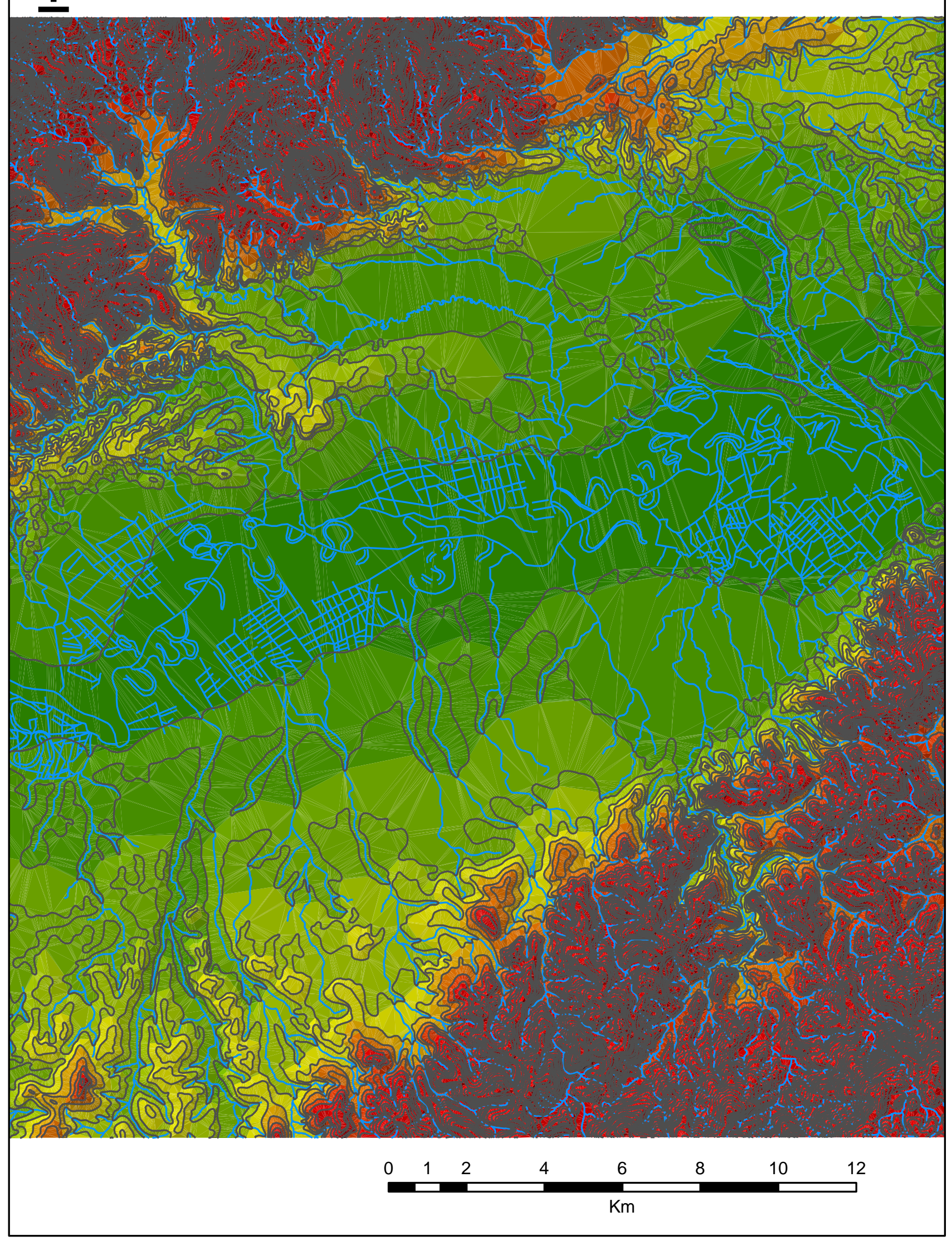


Prancha 1 - Amostra de Trado - P1

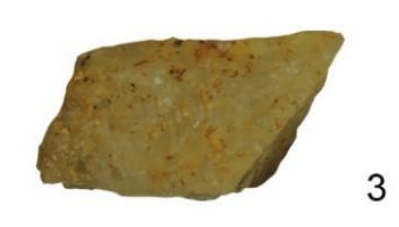

AMOSTRA P1
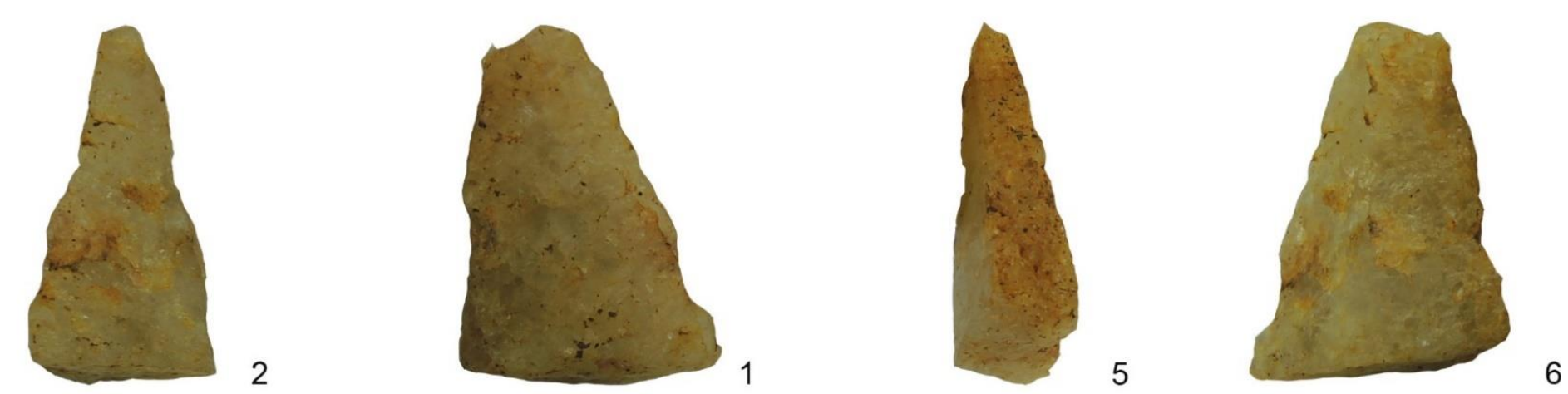

LEGENDA

1 - Face interna

2 - Gume direito

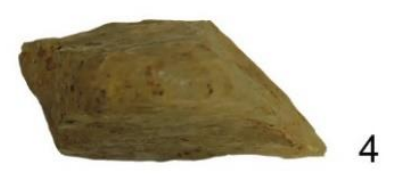

4 - Ponta distal

5 - Gume esquerdo

6 - Face externa

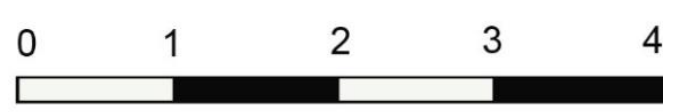

Fonte: Prospecção arqueológica realizada em 29/01/2017. Org. Leal, 2017. 


\section{Prancha 2 - Amostra de Trado P3}

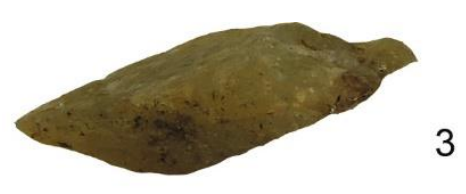

AMOSTRA P3
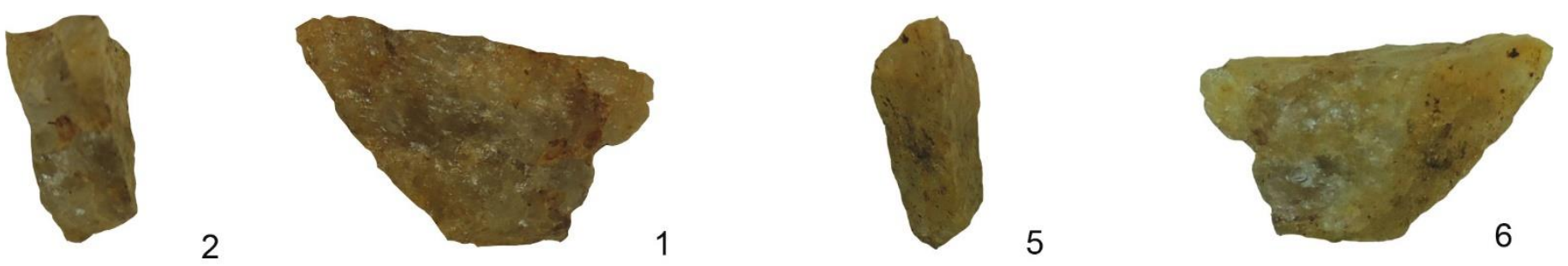

\section{LEGENDA}

1 - Face interna

2 - Gume direito

3 - Talão

4 - Pnnta distal

5 - Gume esquerdo

6 - Face externa

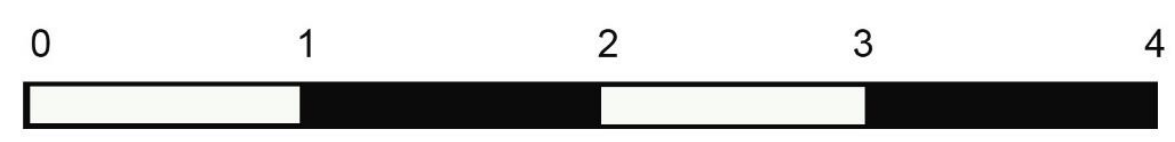

Fonte: Prospecção arqueológica realizada em 30/01/2017. Org. Leal, 2017. 


\section{Prancha 3 - Amostra de Trado P7}
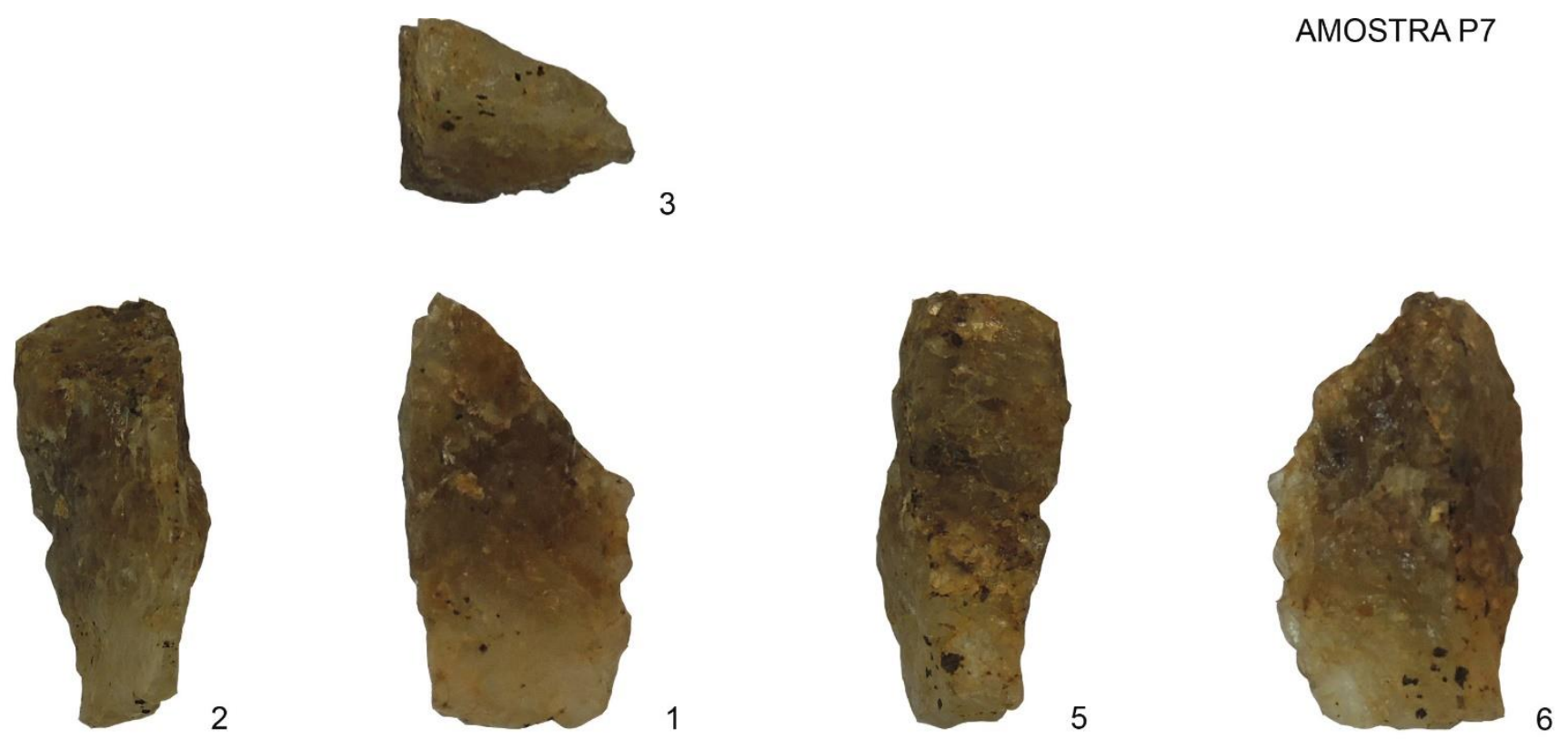

$$
\begin{aligned}
& \text { LEGENDA } \\
& 1 \text { - Face interna } \\
& 2 \text { - Gume direito } \\
& 3 \text { - Talão } \\
& 4 \text { - Pnnta distal } \\
& 5 \text { - Gume esquerdo } \\
& 6 \text { - Face externa }
\end{aligned}
$$

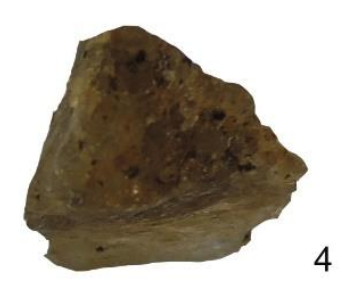

4

Fonte: Prospecção arqueológica realizada em 29/01/2017. Org. Leal, 2017. 
Prancha 4 - Amostra de Quadra 1A

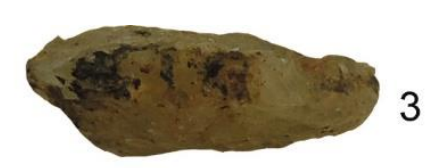

AMOSTRA 1 A - QUADRA A50
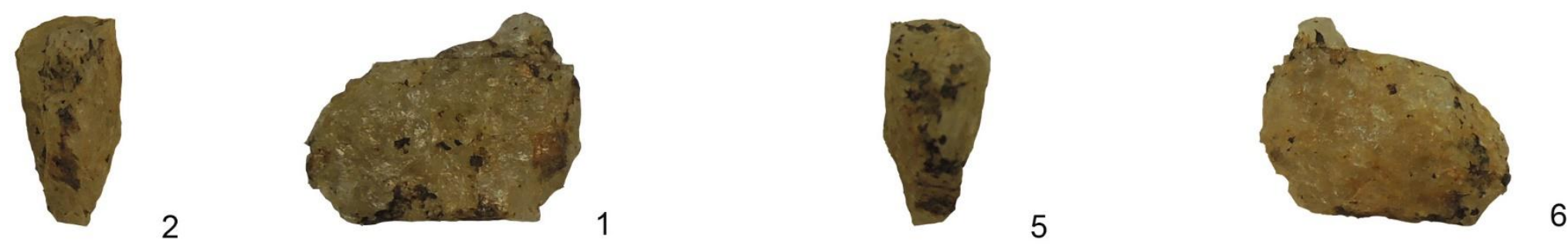

\section{LEGENDA}

1 - Face interna

2 - Gume direito

3 - Talão

4 - Pnnta distal

5 - Gume esquerdo

6 - Face externa

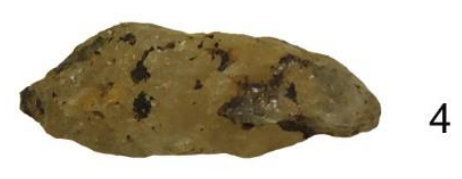

Fonte: Prospecção arqueológica realizada em 29/01/2017. Org. Leal, 2017. 


\section{Prancha 5 - Amostra de Quadra 2A}
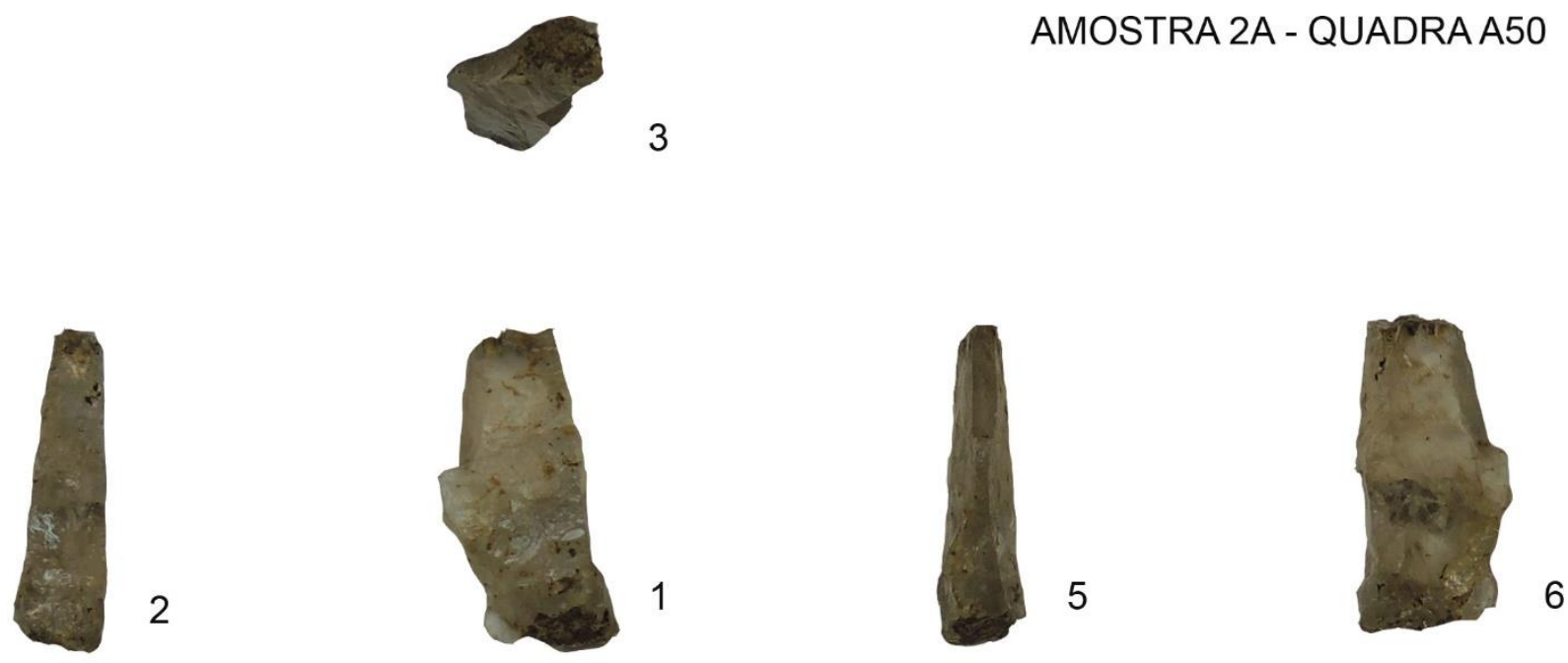

\section{LEGENDA}

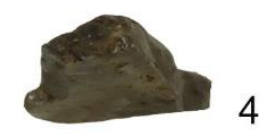

1 - Face interna

2 - Gume direito

3 - Talão

4 - Pnnta distal

5 - Gume esquerdo

6 - Face externa

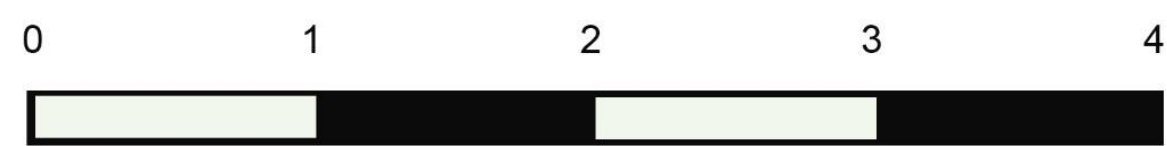

Fonte: Prospecção arqueológica realizada em 29/01/2017. Org. Leal, 2017. 


\section{Prancha 6 - Amostra de Quadra 1B}

2

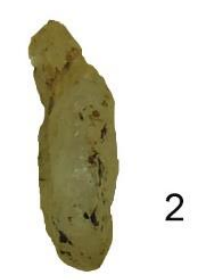

\section{LEGENDA}

1 - Face interna

2 - Gume direito

3 - Talão

4 - Pnnta distal

5 - Gume esquerdo

6 - Face externa

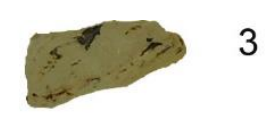

AMOSTRA B1 - QUADRA A50
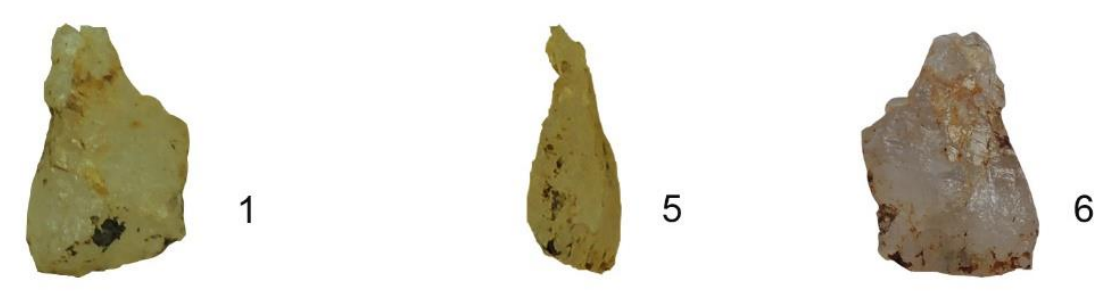

Fonte: Prospecção arqueológica realizada em 29/01/2017. Org. Leal, 2017. 
Prancha 7 - Amostra de Quadra 2B

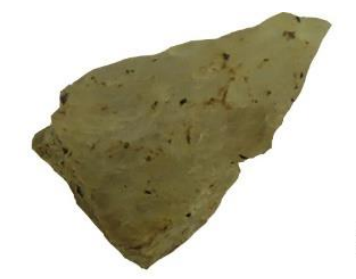

LEGENDA

1 - Face interna

2 - Gume direito

3 - Talão

4 - Pnnta distal

5 - Gume esquerdo

6 - Face externa
2
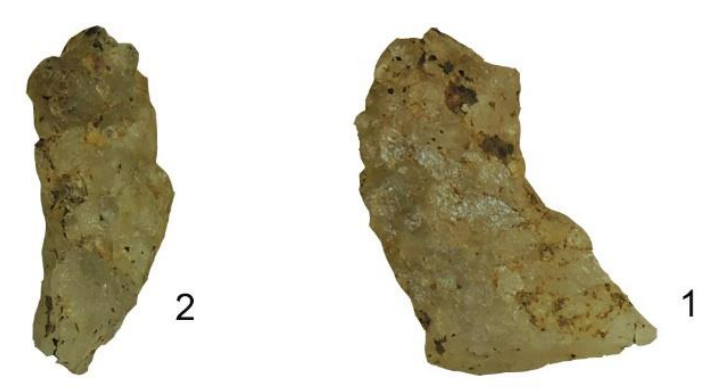

5

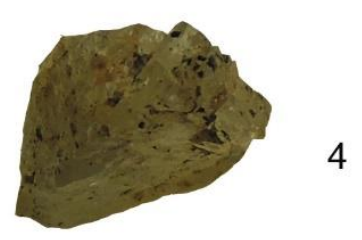

0

1

2

3

4

Fonte: Prospecção arqueológica realizada em 29/01/2017. Org. Leal, 2017. 


\section{Prancha 8 - Amostra de Quadra 3B}
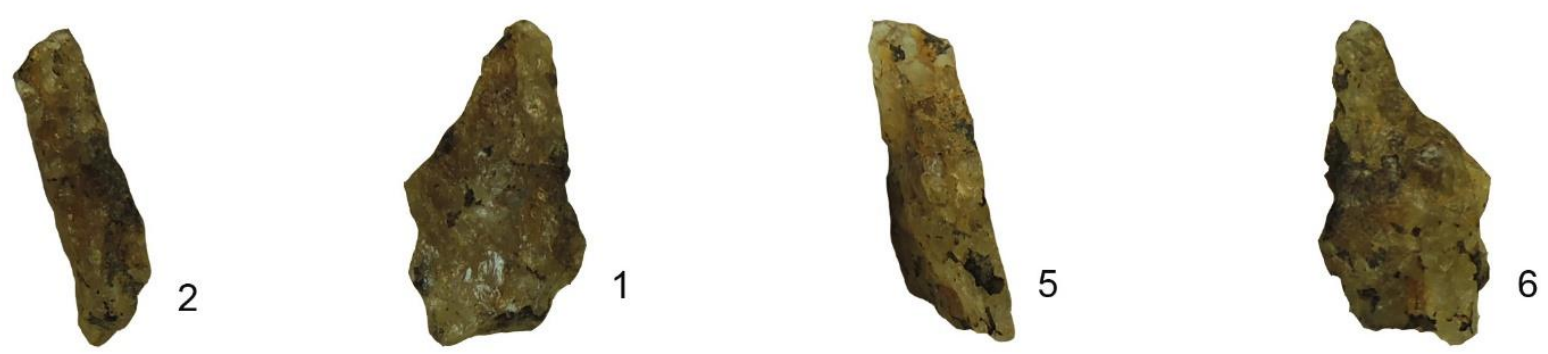

\section{LEGENDA}

1 - Face interna

2 - Gume direito

3 - Talão

4 - Pnnta distal

5 - Gume esquerdo

6 - Face externa

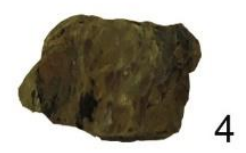

\begin{tabular}{lllll}
0 & 1 & 2 & 3 & 4 \\
\hline & & &
\end{tabular}

Fonte: Prospecção arqueológica realizada em 29/01/2017. Org. Leal, 2017. 


\section{Prancha 9 - Amostra de Quadra 4B}
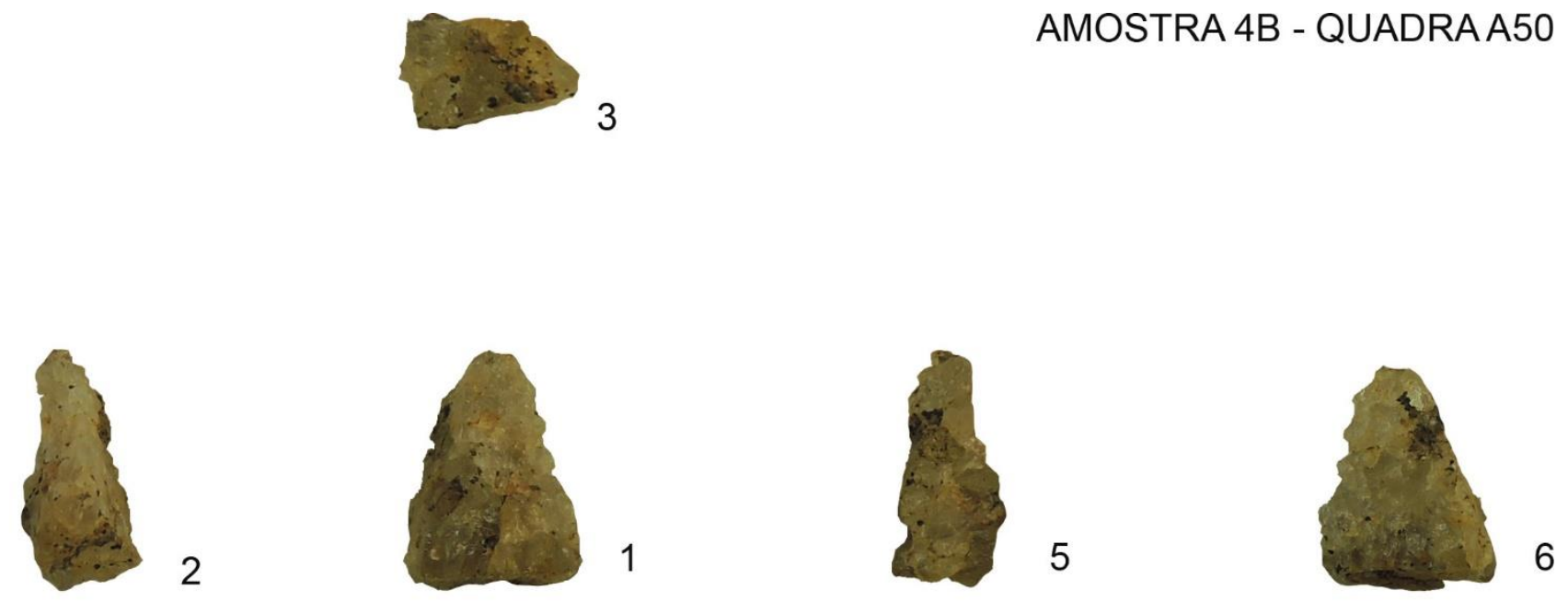

\section{LEGENDA}

1 - Face interna

2 - Gume direito

3 - Talão

4 - Pnnta distal

5 - Gume esquerdo

6 - Face externa
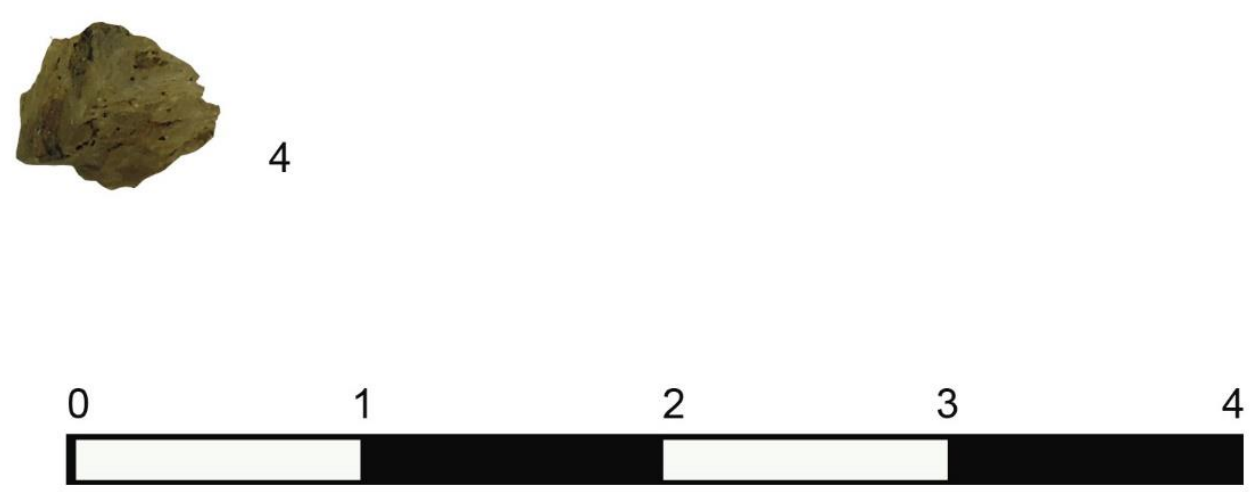

Fonte: Prospecção arqueológica realizada em 29/01/2017. Org. Leal, 2017. 
Prancha 10 Amostra de Quadra 5B

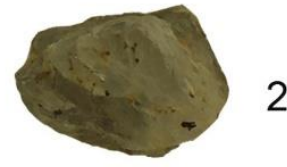

LEGENDA

1 - Face interna

2 - Gume direito

3 - Talão

4 - Pnnta distal

5 - Gume esquerdo

6 - Face externa

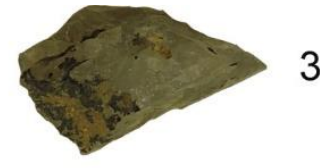

3

AMOSTRA 5B - QUADRAA50
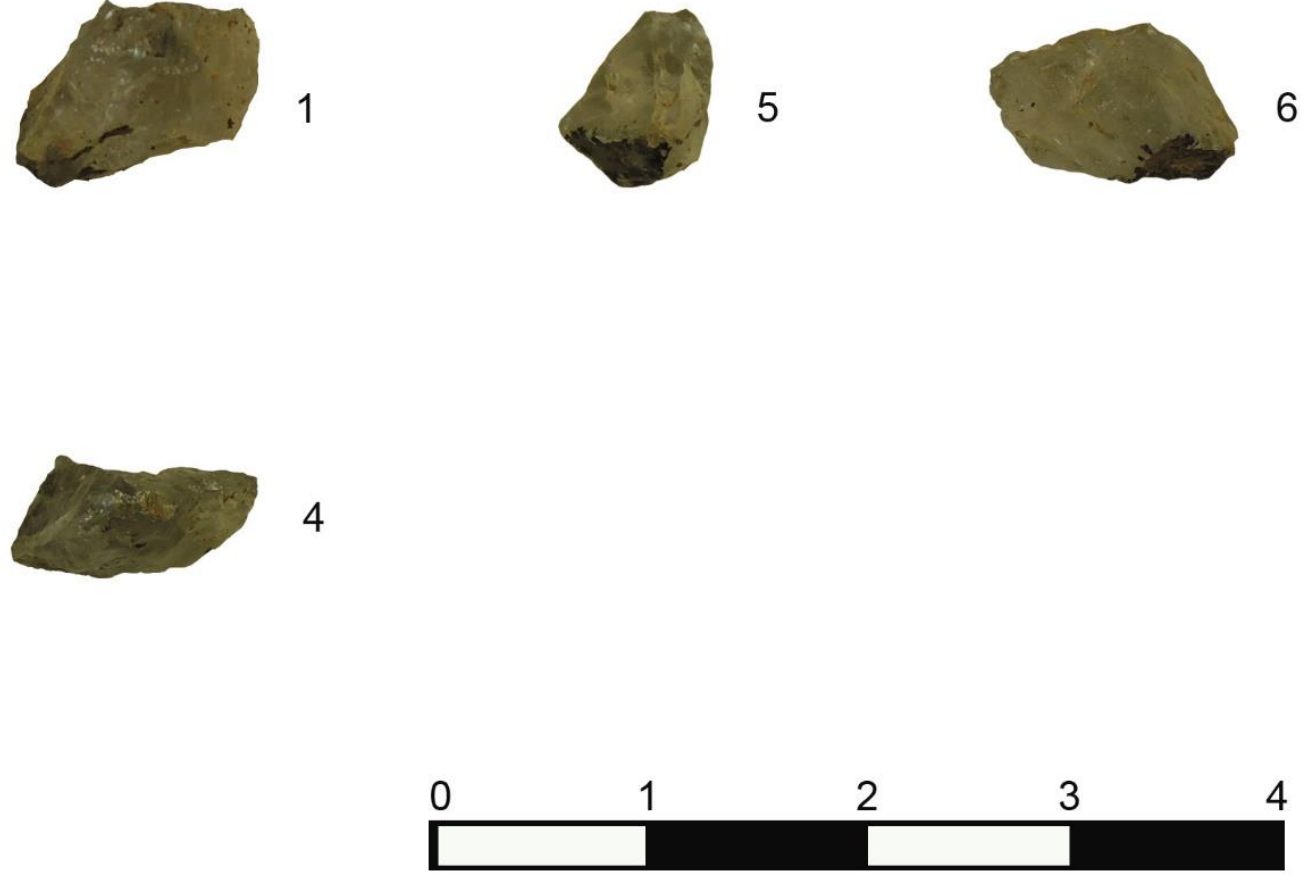

Fonte: Prospecção arqueológica realizada em 25/03/2017. Org. Leal, 2017. 
Prancha 11 - Detalhes do fragmento de cerâmica: estria, antiplástico e talvez "banho".
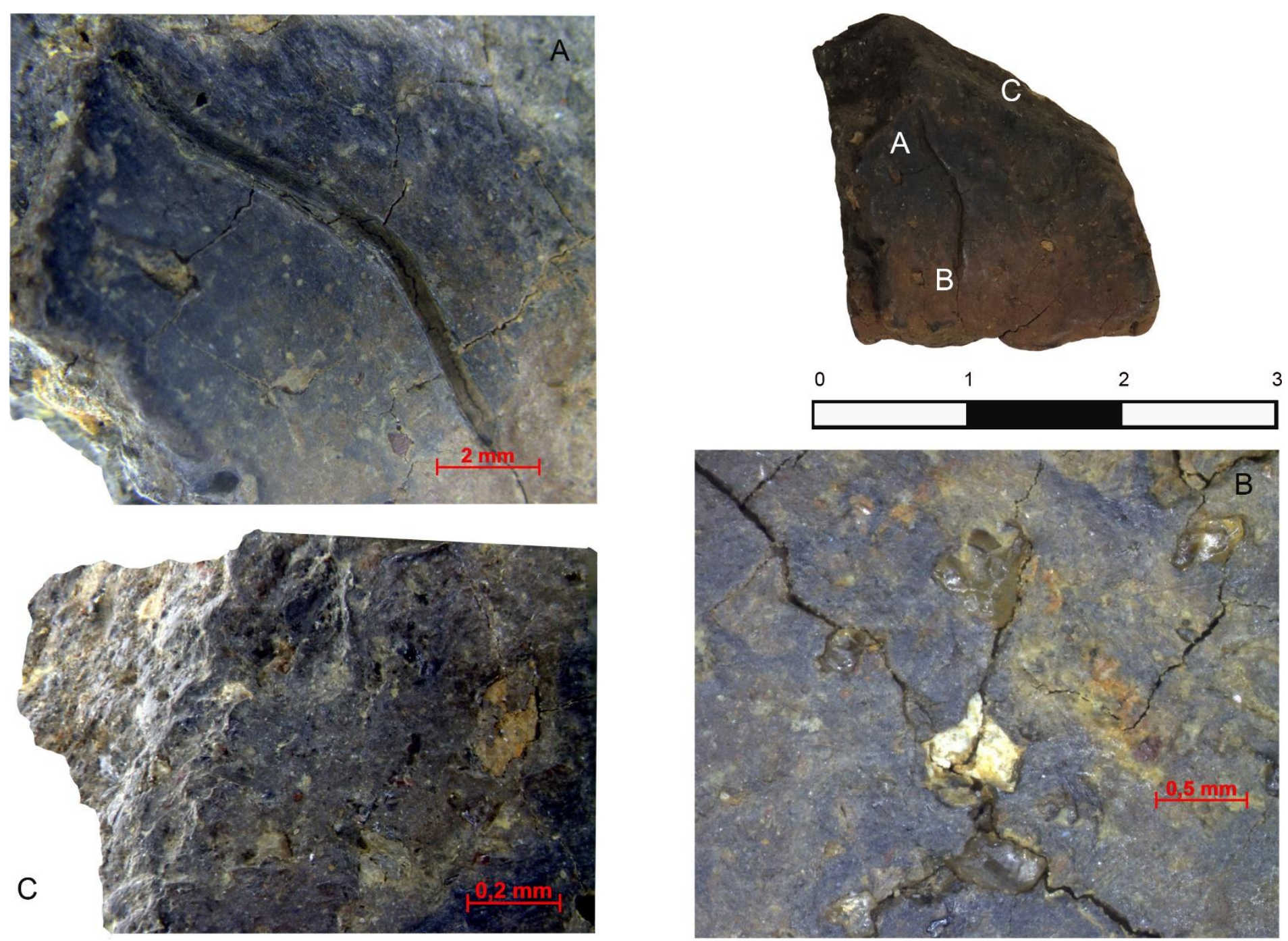

Fonte: Prospecção arqueológica realizada em 02/02/2017. Org. Leal, 2017. 
MAPA DE POTENCIAL ARQUEOLÓGICO (PRÉ-CAMPO)

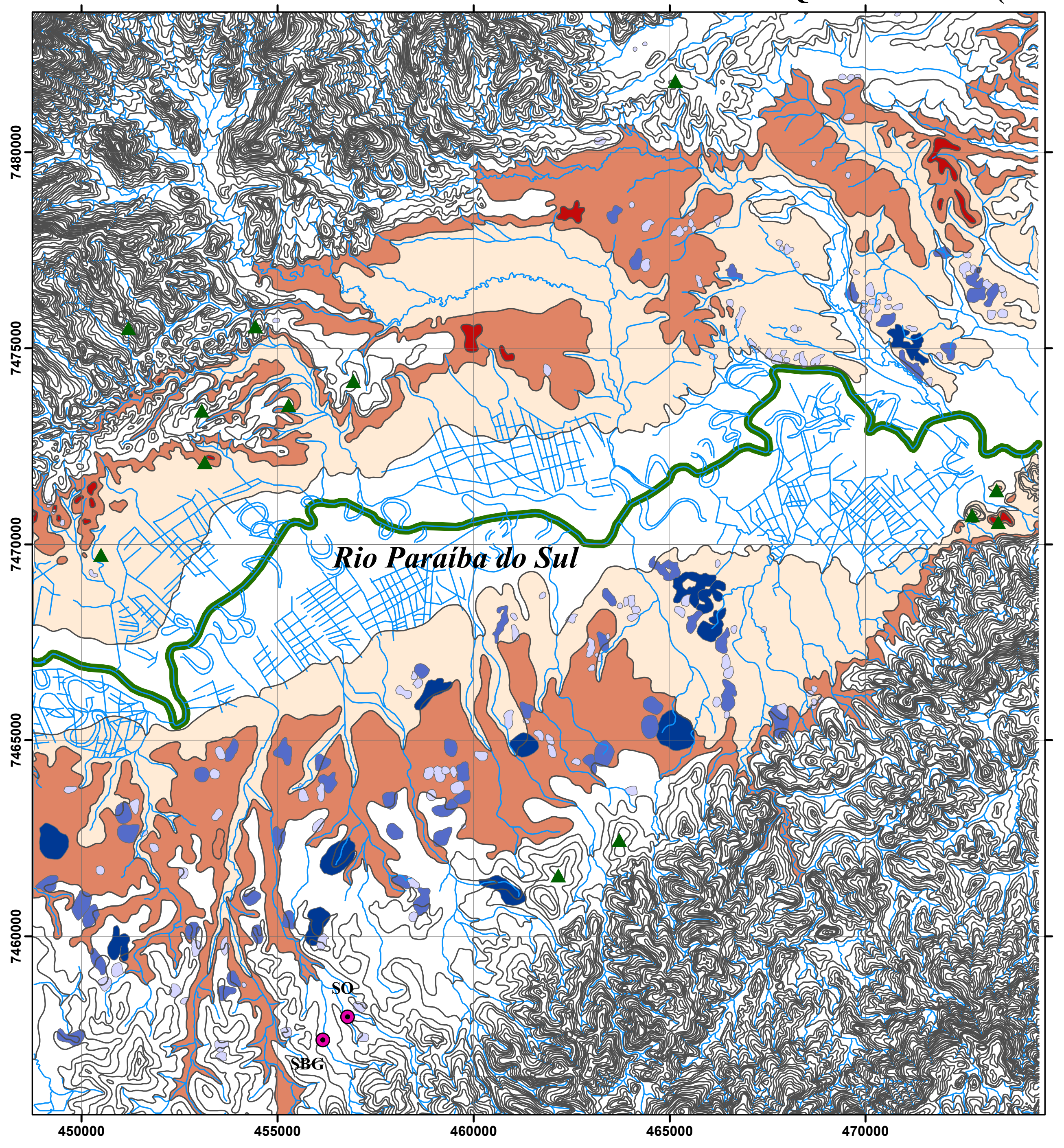

\section{Legenda}

- Colinas

\section{Áreas Altas Adjacentes (m)}

\begin{tabular}{|l}
580 a 600 \\
560 a 580 \\
560
\end{tabular}

\section{Depressões Interfluviais}

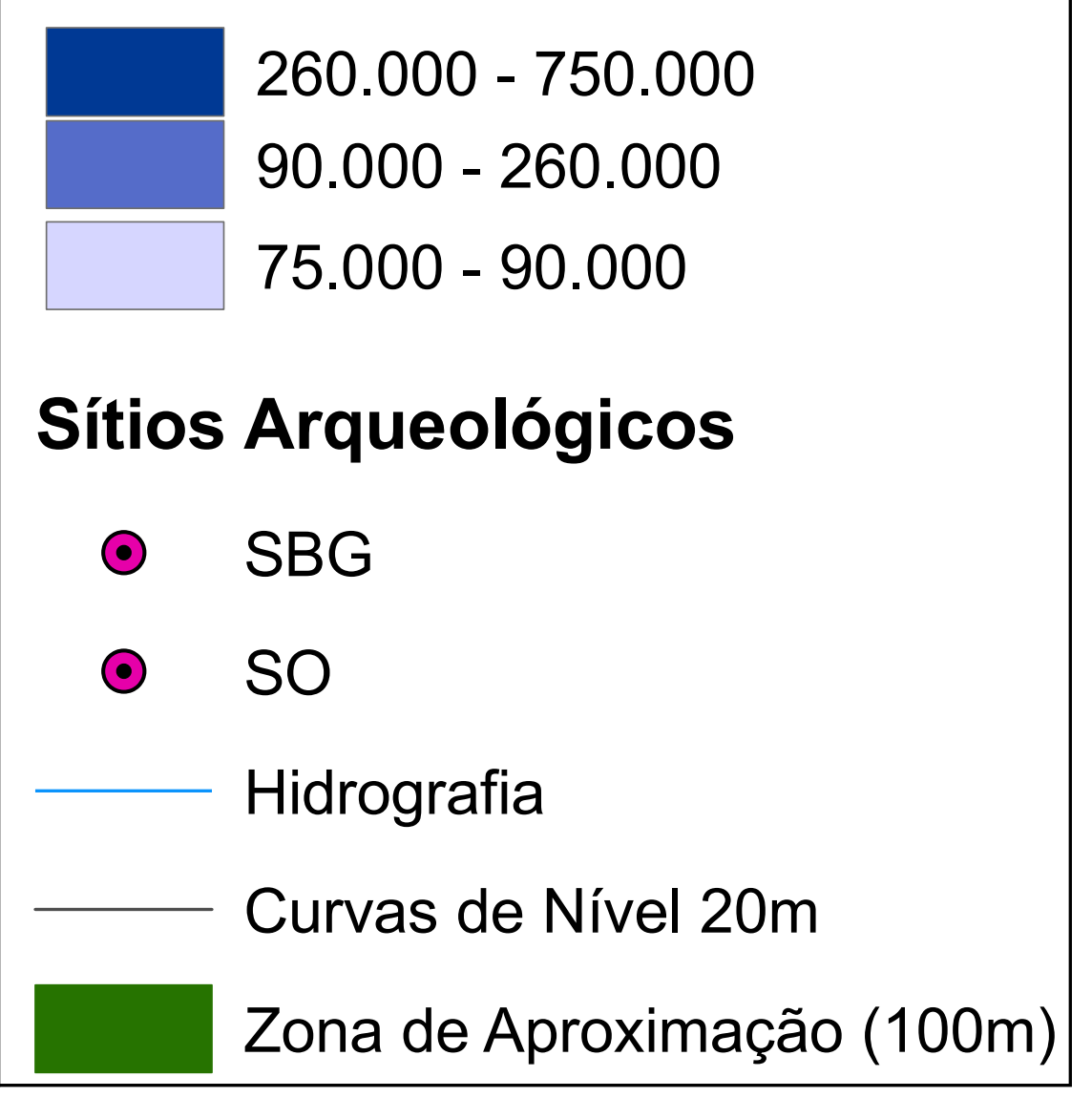

Sistema de Coordenadas UTM ZONA 23S

DATUM: SAD 69

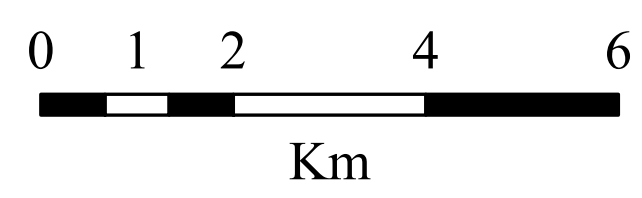




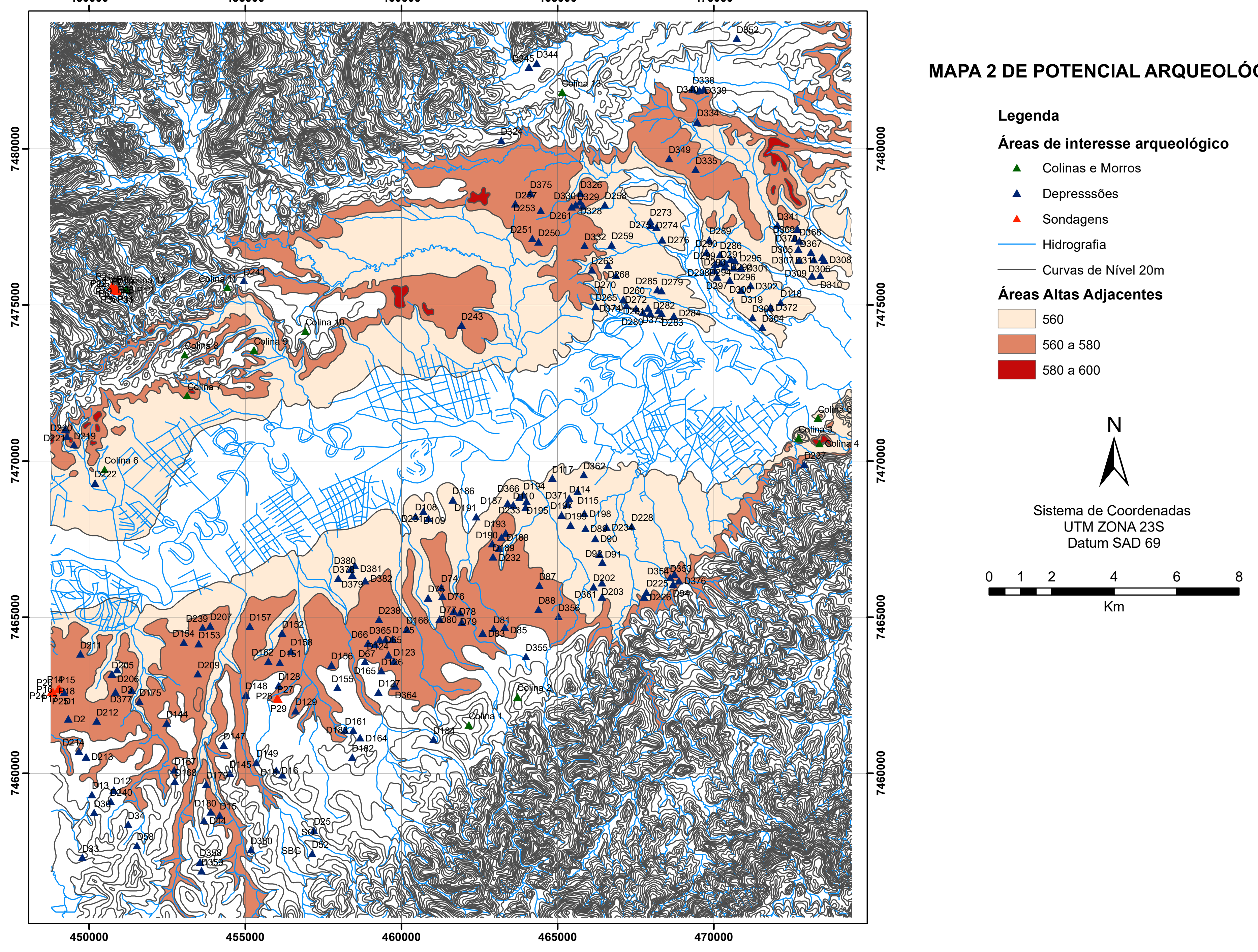

